\title{
관광산업 고용안전망 \\ 구축방안
}

A Study on the Employment Safety Net for the Tourism Industry 



\section{관광산업 고용안전망 구축방안}

A Study on the Employment Safety Net for the Tourism Industry

안희자·윤혜진·정란수 



\section{연구책임}

안희자 한국문화관광연구원, 부연구위원

\section{공동연구}

윤혜진 배화여자대학교 글로벌관광과, 교수

정란수 대안관광컨설팅 프로젝트수, 대표 

관광산업 고용안전망 구축방안

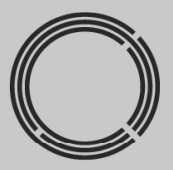

연구개요 



\section{1. 연구배경 및 목적}

\section{가. 코로나19 위기는 관광산업의 일자리 위기로 확산}

- 코로나19로 인한 관광산업의 피해는 고용 불안과 일자리 위기로 이어져 산업 생태 계를 위협하고 있으며(OECD, 2020), 코로나19의 영향으로 관광일자리와 노동시 장도 많은 변화가 예상됨

- 코로나 19 로 고용보험제도가 실질적으로 다수의 일하는 사람을 법적 사각지대에 방치한다는 점이 부각되면서, '전국민 고용안전망 구축’이 국가 아젠다로 부상하며 고용안전망 구축을 위한 분야별 논의와 해법 모색이 요구됨

\section{나. 관광산업에서 고용정책, 일자리 정책의 과제 대두}

- 코로나19 위기 상황에서 정부의 정책 지원이 우선되어야 할 부분은 고용 유지로, 관광산업 고용안전망 구축은 인적 서비스를 바탕으로 한 관광산업의 경쟁력과 직 결되며, 양질의 인적자원 확보를 위해서도 반드시 필요한 과제임

- 고품질의 관광서비스 제공은 관광산업 종사자가 충분히 존중받을 수 있는 노동조 건에서 가능하며, 관광산업 종사자의 노동권이 보장될 때 인적 서비스를 기반으로 하는 관광산업의 지속가능한 발전이 가능함(이경희·김근주, 2019)

\section{다. 관광산업의 고용안전망 사각지대 파악과 향후 정책 대응 전략 모색 필요}

- 코로나 19 의 관광기업 지원을 위하여 정부는 관광업을 특별고용업종으로 지정하 고, 고용유지지원금 등 다양한 지원 정책을 추진하였으며, 코로나 19 가 장기화되면 서 이 같은 고용지원정책의 실효성과 효과성에 대한 검토가 필요한 시점임

- 코로나 19 는 고용 정책에서 사회적 보호의 사각지대를 재확인하는 계기로, 정부의 고용 지원 정책이 미치지 않는 사각지대에 대한 점검이 필요하며, 향후 정부의 정 책 환경 변화에 대응한 방향과 전략 모색이 요구됨

본 연구는 관광산업의 고용 현황과 실태를 파악하고 고용안전망의 사각지대를 진단 하여 향후 정책 환경 변화에 대응한 관광산업 고용안전망 구축 방향과 과제를 도출 하는 데 목적을 둠 


\section{2. 고용안전망의 개념 및 정책 동향}

- 고용안전망은 노동시장에서 실업의 위험에 대응하기 위한 체계를 말하며, 원칙적 으로 고용보험이 1차적 고용안전망으로 중심을 이루는 제도임

- 관광산업 고용안전망은 실직, 산업재해, 질병 등 사회적 고용 상 위험으로부터 관 광분야 종사자를 안전하게 보호하는 법제도적 체계로 정의할 수 있음

- 고용 안정으로 개인과 가정, 나아가 사회의 안정을 유지하고, 다시 일할 수 있는 기회와 일자리 이동을 위해 고용보험 제도를 통해 지원하는 사회시스템으로 봄

- 고용안전망에 대한 접근은 사각지대를 파악하고, 사각지대 해소를 위한 제도적 방 안을 확대하는 것이 중요함

- 고용안전망 사각지대의 유형은 업종에 따라 다양하게 나타나는데, 현실적인 이유 로 고용보험 가입 대상이나 가입하지 못하는 경우, 근로자가 아니기 때문에 고용보 험에 가입하지 못하는 경우, 고용보험 가입 대상이나 적용 제외 신청을 하는 경우 등을 포함하고 있음

- 정부는 2017년부터 '일자리 강화' 정책을 목표로, 포괄적인 사회보험을 구축하여 기존 사각지대 해소 방안을 발표해왔으며, 이러한 연장선에서 2020년 발표한 전 국민 고용보험제도 도입은 우리나라 고용안전망 강화 정책의 중요한 변곡점임

- 전국민 고용보험 도입은 기존 고용안전망의 사각지대에 놓여있는 사람들을 점진적 으로 포괄하는 고용보험의 단계적 확대와 국민취업지원제도를 시행하는 고용안전 망 강화라고 볼 수 있음

- 우선적으로 미가입자의 가입을 유도하는 정책과 사각지대 해소, 궁극적으로 일 하는 사람 전부에게 고용보험 적용을 확대한다는 것을 골자로 함

- 고용안전망 정책은 정부가 추진하는 전국민 고용보험 로드맵의 정책 흐름에 대응 하여 관광산업 영역에서 요구되는 정책 과제를 발굴하고, 지원 방안 모색이 요구 됨, 특히 산업적 관점에서 고용보험 적용 부분 확대에 집중할 필요가 있음

- 상시적 위기의 시대에 대비하여, 코로나 19 를 관광산업의 위기대응 체계를 구축하 는 계기로 삼아 고용안정성을 높이기 위한 제도적 방안을 모색할 필요가 있음 


\section{3. 고용안전망 관련 제도 및 사례 분석}

- 고용안전망 구축 관련 주요 제도 및 국내외 사례를 분석하고, 향후 국내 고용안전 망 정책 발굴을 위한 시사점을 도출함

- 국내 사례는 우리나라의 고용보험제도의 전반적인 내용과 산업의 위기 상황에 대 비한 고용위기산업 지원제도, 예술인 고용보험제도의 사례를 분석함

- 국외의 고용안전망 시례는 OECD와 UNWTO 등에서 발표한 주요국의 코로나19 대응 정책사례를 통하여 해외 주요 국가에서 코로나 19 로 가해진 노동시장의 충격 완화를 위하여 어떠한 정책을 추진하는지 분석함

- 국외의 경우 관광 부문의 고용유지를 위한 재정 지원과 교육 지원이 공통적으로 나타났고, 스위스 호텔업계의 단축 노동을 통한 일자리 나누기 정책, 프랑스의 관 광가이드 대상 재정 지원 정책 등을 추진함

〈표 1〉 국외의 고용 지원 정책 사례 종합

\begin{tabular}{l|l}
\hline \multicolumn{1}{c|}{ 고용/노동 지원 제도 } & \multicolumn{1}{c}{ 관광 부문 지원 제도 } \\
\hline - 고용유지제도 & - 관광 직업 훈련에 대한 추가 부담금 감면 \\
- Short-time work 제도 & - 관광산업 보호를 위한 임금 보조금 지원 \\
- 임시 임금보조 제도 & - 인턴 직원들을 위한 재정 지원 \\
- 해고 근로자 보호 & - 디지털 관련 업무 교육 시행 기업 지원 \\
- 피해근로자 소득보장 및 고용 지원 & - 관광종사자 대상 하는 교육 지원 (실업자 포함) \\
- 코로나19 위기 중 실업급여 확대 & - 관광업계 고용 지원을 위한 전담부서 역량강화 \\
- 비정규직 근로자 조치 & 프로그램 \\
- 구직자를 위한 고용서비스 및 훈련 지원 & \\
\hline
\end{tabular}

- 국외 사례에서 도출한 시사점은 산업의 위기 시 휴업 또는 노동시간을 단축하며 고용을 유지하는 것은 기업의 미래 경쟁력과 성장에 도움이 된다는 점임

- 스위스 호텔협회에서도 ‘단축노동’이 위기 극복을 위한 가장 중요한 수단으로 인식하고 있으며, 여기에는 임금 보전을 위한 국가의 지원금(독일, 스위스의 경 우 ‘단축노동수당')이 필수적이며, 이는 소비도 줄어들지 않게 만들어 전체 산업 이 침체되지 않도록 하는 역할도 함

- 앞으로 심화될 불확실성의 시대에 대비하기 위하여, 관광업계 종사자들이 갖는 고 용불안을 해소할 수 있는 촘촘한 고용안전망 정책 설계가 필요함 


\section{4. 관광산업 고용안전망 실태 분석 및 진단}

\section{가. 관광산업 고용안전망 실태분석 결과}

- 관광산업 주요 업종별 고용형태 등 노동시장 특성을 파악하고 고용안전망 사각지 대의 실태를 파악하는데 주안점을 두고, 고용안전망 사각지대 실태 규명을 위하여 고용유지지원금 수급 현황, 긴급고용안정지원금 수급자 통계 등을 분석함

- 고용유지지원금을 받고 있는 사업체와 종사자는 관광사업체조사에서 파악된 전체 업종 규모의 약 10 20\% 수준인 것으로 나타남

- 긴급고용안정지원금 수급자 통계에서 나타난 사각지대 현황을 살펴보면, 소득감소 율에서 여가관광종사자가 평균 $85.1 \%$ 로 타 직종에 비하여 월등히 높게 나타남

- 심층인터뷰 조사를 통해 도출한 관광산업 노동시장의 특성은 다음과 같음

- 관광산업은 일용직 및 초단시간 근로자, 자영업자, 프리랜서 등 고용형태가 다 양하게 나타나 상용근로자 중심으로 설계된 현재의 고용보험으로는 한계가 있 으므로 관광산업 종사자 중 고용보험 사각지대가 적지 않을 것으로 추정됨

- 정확한 규모를 파악하기 어려우나 업종에 따라 임시·일용직을 많이 활용하고 있으며 외주화에 따른 용역노동, 특수고용 종사자가 적지 않아 고용위기 시 소 득단절이 예상되므로 이를 제도적으로 보호할 필요가 있음

〈표 2〉심층인터뷰 조사 결과

\begin{tabular}{c|l}
\hline 범주 & \multicolumn{1}{c}{ 주제 } \\
\hline \multirow{2}{*}{$\begin{array}{c}\text { 노동집약적 특성이 우세한 } \\
\text { 관광산업 고용 현실 }\end{array}$} & 진입장벽이 낮음 \\
\cline { 2 - 2 } & 전공역량 및 스펙 보다 태도 중시 \\
\cline { 2 - 2 } & 인력 중심의 서비스 제공 구조 \\
\hline \multirow{4}{*}{ 업의 전문성, 자부심 결여 } & 높은 이직률, 잦은 이직 고민 \\
\cline { 2 - 2 } & 외부 시각과 현실과의 높은 괴리감 \\
\cline { 2 - 2 } & 정규직보다 높아지는 비정규직화 추세 \\
\cline { 2 - 2 } & 낮은 보수체계와 처우로 인한 회의감 \\
\hline 낮은 고용 안정성 & 외부 환경변화에 민감 \\
\hline \multirow{2}{*}{ 관광분야 고용 불안정성과 } & 산업구조의 영세성과 정부지원 사각지대 \\
\cline { 2 - 2 } 사각지대 발생 & 고용 환경의 열악함 인식 \\
\cline { 2 - 2 } & 고용보험 제도화의 제약 요인 \\
\hline \multirow{2}{*}{ 코로나19 이후 심화된 } & 코로나19로 휴직, 희망퇴직, 정리해고, 폐업 등 고용/일자리 감소 \\
\cline { 2 - 2 } 고용 및 일자리 위기 & 코나19로 심화된 관광분야 고용의 질 저하 \\
\cline { 2 - 2 } & 정부의 고용유지지원 수혜 인식과 한계 발생 \\
\hline \multirow{2}{*}{ 정규직 이외의 다ㅇㅑㅑ하고 불안정한 } & 계절성, 성/비수기 발생 요인 \\
\cline { 2 - 2 } 고용 형태 & 경영 이익을 위한 값싼 노동력 대체 현상 \\
\cline { 2 - 2 } & 다양한 고용 형태 속 갈등 심화 \\
\hline
\end{tabular}




\section{나. 관광산업 고용안전망 사각지대 진단}

- 앞서 언급된 고용안전망의 사각지대에 대한 업종별 심층인터뷰 분석결과와 심층인 터뷰에서는 직접적으로 드러나지는 않았으나 앞서 연구 내용을 토대로 고용안전망 사각지대를 규명함

- 이 연구에서 고용안전망 사각지대는 관광산업 중 여행업, 관광숙박업, 국제회의 기획업을 중심으로 제시함

- 따라서 제시된 고용안전망 사각지대는 기준 시기와 특성에 따라서 변화될 수 있기 때문에 지속적인 모니터링을 통해 검토가 필요함

[그림 1] 관광산업 고용안전망 사각지대 결과

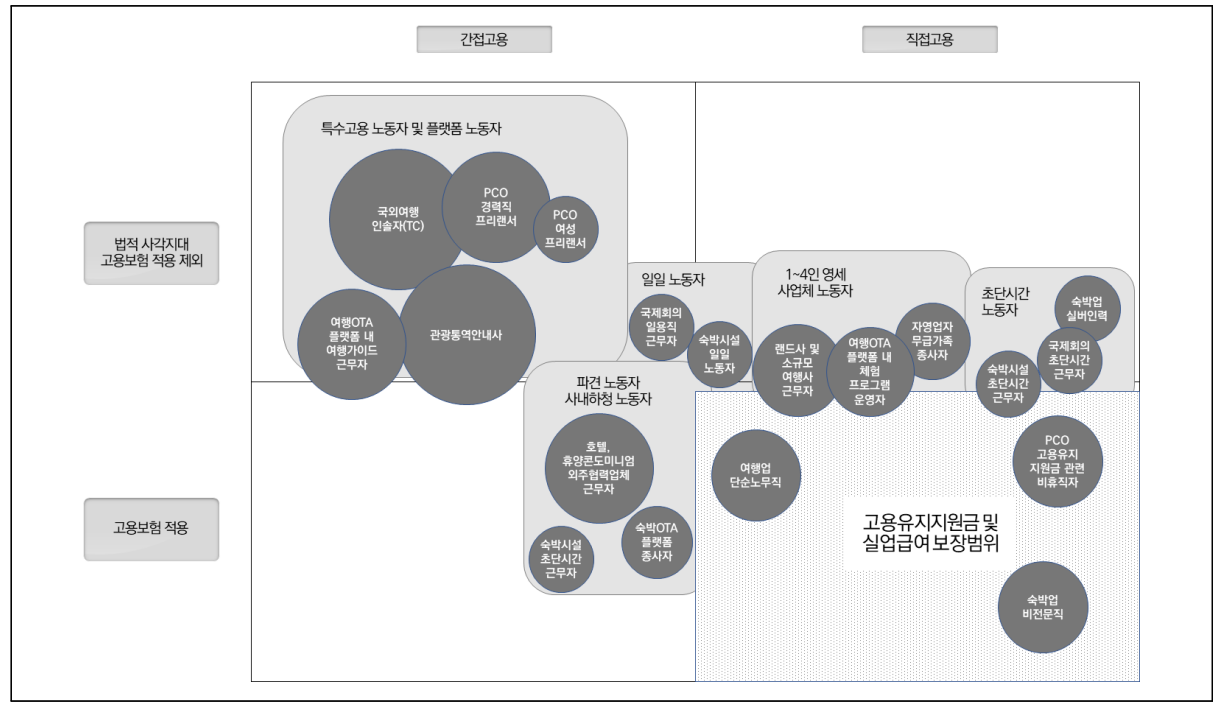




\section{5. 관광산업 고용안전망 강화를 위한 과제}

- 코로나19 이후 급변하는 고용-노동 환경에 대응하기 위해 탄탄한 고용안전망을 구축하고, 관광산업에서 사람에 대한 투자를 강화하는 정책 방향 설정이 필요함

- 고용과 일자리는 관광산업 정책에서 무엇보다 중요한 과제이며, 종사자의 고용안 정을 도모하면서 관광기업의 지속가능성을 강화하는 균형적 접근이 요구됨

- 이러한 배경에서 관광산업 고용안전망 강화를 위한 정책 방향과 과제를 제시함

\section{가. 관광산업 고용안전망 사각지대 해소}

- 관광산업 고용안전망 사각지대 개선에 대한 정책방향은 관광산업 종사자들이 어떠 한 업종이나 직종과 관계없이 직접적인 고용 형태와 고용보험 및 실업급여 적용 범위 내에 포함되어 전국민 고용안전망의 적용 전 전문성과 안전성 강화를 위한 기반을 수립하는 것을 그 목표로 함

- 특수형태근로종사자와 영세자영업자가 고용보험제도로 편입되는 노동시장정책이 논의되고 있다는 점을 고려할 때, 관광산업의 고용보험 사각지대 발굴과 실태 규명 을 통하여 사각지대 해소 정책을 추진할 필요가 있음

- 최근 고용정책이 디지털 시대의 고용안전망, 플랫폼 노동의 확산에 대한 대응방안 모색 등 고용안전망의 범위가 확대되는 추세임을 고려하여, 디지털 전환과 같은 여러 관광의 변화 속에서 관광산업 종사자들의 근무환경이나 직종 변경이 필요한 경우까지 고려하여 광범위한 수준에서의 고용의 안전성을 지속할 수 있는 체계 마 련도 요구됨

\section{나. 업종별·고용형태별 특성을 고려한 사각지대 해소}

- 전반적인 관광산업의 고용안전망 흐름에 대한 대응뿐 아니라 각 업종별, 고용형태 별 다양한 고용 사각지대가 존재하는 만큼 이에 대한 다양한 문제점에 대한 대응이 요구되며, 고용형태의 다양화는 업종별 특성이 비교적 명확히 나타나 업종 특성별, 기업 규모별 대응전략을 달리 설정할 필요가 있음 


\section{다. 관광종사자의 전문성 강화를 위한 지원 확대}

- 관광산업은 인적자원이 중요한 산업으로, 관광객에게 고품질의 서비스를 제공하기 위해서는 인적 서비스가 수반되어야 하며, 서비스 품질의 강화는 관광산업 종사자 의 서비스 전문성 강화, 나아가 관광산업 경쟁력 강화와도 연결됨

- 관광산업 정책에서 양질의 일자리 조성과 인적 자원, 노동환경의 개선이 강조되며, 노동환경의 개선은 관광산업의 서비스 품질 강화와 직결되므로 관광산업에서도 근 로 조건 개선을 위한 정부와 사업자 공동의 노력이 필요

\section{라. 관광산업 고용안전망 구축을 위한 정책 기반 마련}

- 관광산업 진흥 정책과 법제도적 틀에서도 인적 인프라에 직접적으로 지원할 수 있 는 근거를 마련하는 게 중요하므로, 고용유지지원금 제도와 같이 고용노동부의 정 책과 차별화된 관광종사자 대상 지원 제도 마련을 적극적으로 검토 필요

- 관광산업은 제도적으로 고용안전망 관련 지원이 상당히 미흡한 실정이므로, 특히, 고용 관점에서 일자리 전환이 일어나는 직종이 아니고 관광산업에 입직하게 되면 지속 종사하는 종사자들이 높은 업종과 직종에 대한 지원 강화 필요

〈표 3〉 관광산업 고용안전망 강화를 위한 정책 방향과 과제

\begin{tabular}{c|l}
\hline 방향 & \multicolumn{1}{c}{ 정책 과제 } \\
\hline $\begin{array}{c}\text { 관광산업 고용안전망 } \\
\text { 사각지대 해소 }\end{array}$ & $\begin{array}{l}\text { (1) 관광가이드의 고용보험 적용 검토 } \\
\text { (2) 영세업체의 고용안전망 강화를 위한 지원 } \\
\text { (3) 고용유지지원제도 및 특별고용지원제도 보완 }\end{array}$ \\
\hline $\begin{array}{c}\text { 업종별·고용형태별 특성을 } \\
\text { 고려한 사각지대 해소 }\end{array}$ & $\begin{array}{l}\text { (1) 여행업, 관광숙박업, 국제회의기획업 등 업종별 사각지대 해소 } \\
\text { (2) 프리랜서, 임시일용직, 외주협력업체 등 고용형태별 사각지대 해소 }\end{array}$ \\
\hline $\begin{array}{c}\text { 관광종사자의 전문성 강화를 } \\
\text { 위한 지원 확대 }\end{array}$ & $\begin{array}{l}\text { (1) 관광종사자 재교육, 재취업 지원 } \\
\text { (2) 관광종사원 자격제도 정비와 연계한 고용의 질 강화 }\end{array}$ \\
\hline $\begin{array}{c}\text { 관광산업 고용안전망 구축을 } \\
\text { 위한 정책 기반 마련 }\end{array}$ & $\begin{array}{l}\text { (1) 관광산업 종사자 실태조사 } \\
\text { (2) 고용안전망 강화를 위한 법제도 개선 } \\
\text { (3) 업계와 종사자의 인식 개선 및 정책 홍보 }\end{array}$ \\
\hline
\end{tabular}




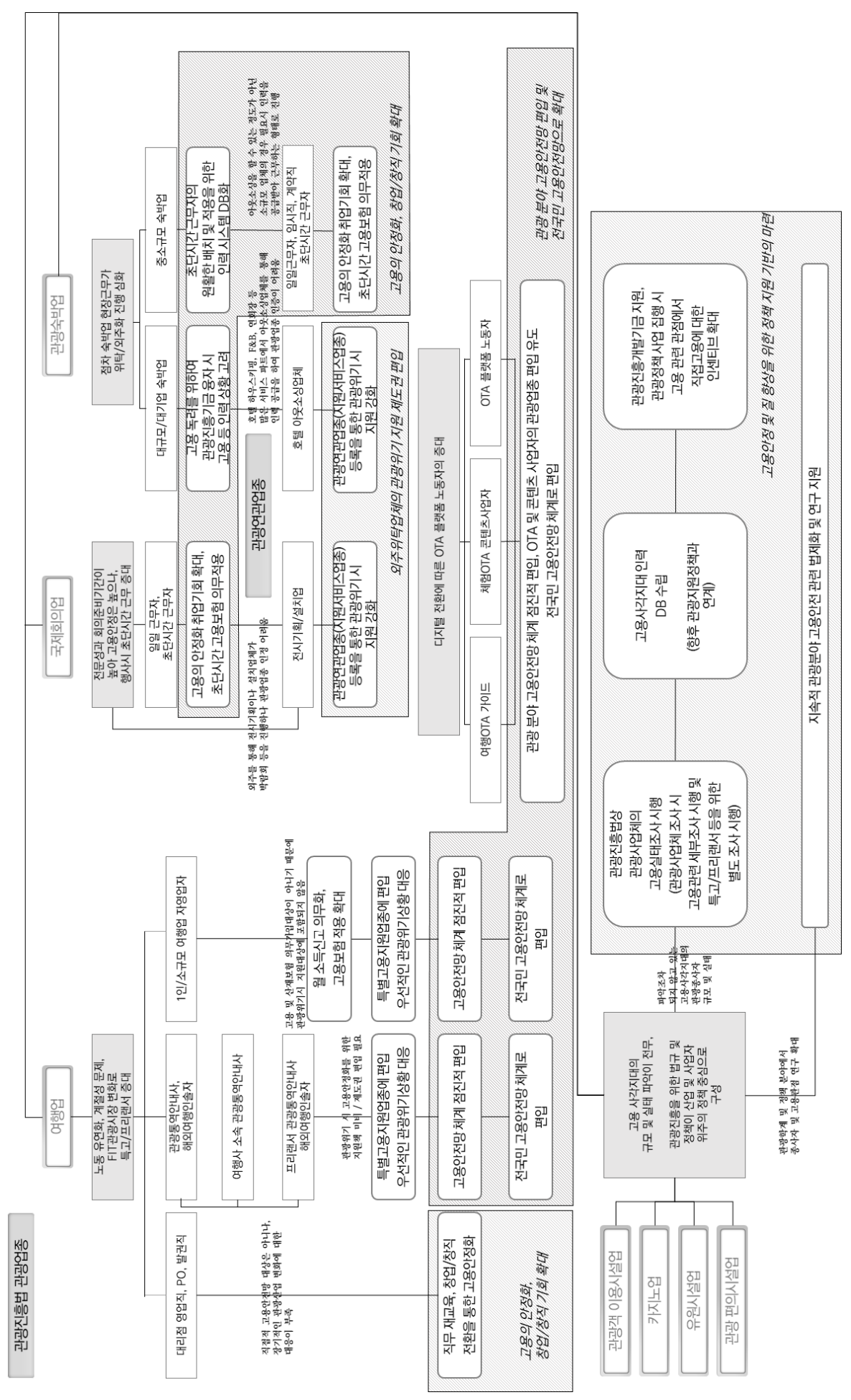




\section{목차}

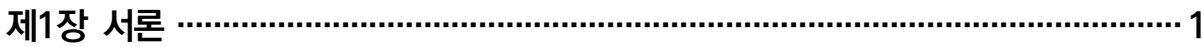

제1절 연구배경 및 목적 3

1. 연구배경 3

2. 연구 목적 6

제2절 연구범위 및 방법 $\quad 7$

1. 연구 범위 7

2. 연구 방법 8

제2장 고용안전망의 개념 및 정책 동향 ……………………………………….....

제1절 고용안전망의 개념과 정책 범위 11

1. 고용안전망의 개념 11

2. 고용안전망 사각지대 12

3. 고용안전망의 정책 범위 15

제2절 고용안전망 관련 정책 동향 17

1. 포용국가 사회정책과 고용안전망 17

2. 전국민 고용보험 로드맵 21

3. 코로나19 지원 고용대책 25

제3절 종합분석 28

제3장 고용안전망 관련 제도 및 사례 분석 ……………………………………..... 31

제1절 우리나라 고용안전망 관련 제도 분석 33

1. 고용보험제도 33

2. 고용위기지역 및 산업(업종) 지원 제도 37

3. 예술인 고용보험제도 39 
제2절 국외 고용안전망 사례 분석 43

1. OECD 국가의 코로나19 대응 사례 43

2. 관광 분야 정책대응 사례 분석 60

제3절 종합분석 및 시사점 66

제4장 관광산업 고용안전망 실태 분석 및 사각지대 진단 ……………………...6 69

제1절 관광산업 노동시장 특성 및 변화 $\quad 71$

1. 관광산업 고용현황 71

2. 코로나19 확산에 따른 노동시장 변화 75

제2절 관광산업 고용안전망 실태 분석 88

1. 고용유지지원금 수급 현황 88

2. 긴급고용안정지원금 수급자 통계 분석 94

제3절 관광산업 고용안전망 실태 파악을 위한 심층인터뷰 결과 101

1. 조사 개요 101

2. 심층인터뷰 결과: 여행업 104

3. 심층인터뷰 결과: 관광숙박업(호텔업, 휴양콘도미니엄업) 111

4. 심층인터뷰 결과: 국제회의기획업(PCO) 118

5. 분석결과 종합 125

제4절 종합분석 및 시사점 128

1. 관광산업 고용안전망 실태분석 결과 128

2. 관광산업 고용안전망 사각지대 진단 129

제5장 관광산업 고용안전망 강화를 위한 과제 ………..................................... 133

제1절 관광산업 고용안전망의 필요성 135

제2절 관광산업 고용안전망 구축 방향과 과제 139

1. 관광산업 고용안전망 사각지대 해소 139

2. 업종별·고용형태별 특성을 고려한 사각지대 해소 146

3. 관광종사자의 전문성 강화 151

4. 고용안전망 구축을 위한 정책 기반 마련 154

5. 정책과제 종합 159 
제6장 결론 및 제언

제1절 결론

제2절 정책 제언

참고문헌 / 169

ABSTRACT / 173 


\section{표 목차}

〈표 1-1〉연구방법 8

〈표 2-1〉2019년 취업자 대상 고용보험 사각지대1) 13

〈표 2-2〉 국정과제 - 일자리 안전망 강화 세부 과제 17

〈표 2-3〉 한국판 뉴딜 종합계획 - 고용·사회 안전망 강화 18

〈표 2-4〉 고용노동부 '든든한 고용안전망 확충' 정책 사업 19

〈표 2-5〉2022년 우리의 고용안전망 모습 20

〈표 2-6〉예술인 고용보험 23

〈표 2-7〉 특고· 플랫폼 종사자 확대 계획 23

〈표 2-8〉 코로나19 고용대책 25

〈표 2-9〉 코로나19 고용대책 - 특별고용지원업종 26

〈표 2-10〉 코로나19 노사정 합의안 27

〈표 3-1〉 특별고용지원업종 지정에 따른 추가지원 내용 38

〈표 3-2〉 예술인 고용보험과 근로자 고용보험 비교 40

〈표 3-3〉예술인의 지위와 권리의 보장에 관한 법률(예술인 권리보장법) 42

〈표 3-4〉국외의 고용 지원 사례 종합 67

〈표 4-1〉 관광사업체 수 총괄표 71

〈표 4-2〉 관광사업체 종사자수 $\quad 72$

〈표 4-3〉2019년 세부 업종별 고용형태 74

〈표 4-4〉 전년 대비 휴직자수 변화(업종별) 75

〈표 4-5〉 전년 대비 퇴직자수 변화(업종별) 76

〈표 4-6〉임금근로자 규모

〈표 4-7〉 비정규직 근로자 규모 78

〈표 4-8〉 고용보험 가입률 78

〈표 4-9〉 종사상 지위별 고용보험 가입률 79

〈표 4-10〉산업별 사업장 현황 80

〈표 4-11〉 산업별 피보험자 현황 81

〈표 4-12〉 산업별 피보험 상실자 현황 82 
〈표 4-13〉 산업별 피보험 수급자격인정자 현황 83

〈표 4-14〉 산업별 실업급여 지급인원 현황 85

〈표 4-15〉산업별 고용안정사업 지원 현황 86

〈표 4-16〉 산업별 직업능력개발사업 지원 현황 87

〈표 4-17〉 2021년 기준 특별고용지원업종 지정 현황 89

〈표 4-18〉 업종별 고용유지지원금 지급 현황 90

〈표 4-19〉 규모별 고용유지지원금 지급 현황 91

〈표 4-20〉업종별 특별고용지원업종 고용유지지원금 지급 현황 91

〈표 4-21〉 규모별 특별고용지원업종 고용유지지원금 지급 현황 92

〈표 4-22〉 코로나19 긴급고용안정지원금 지원사업 94

〈표 4-23〉 직종별 신청자 수 95

〈표 4-24〉 직종별 고용보험 가입이력 96

〈표 4-25〉 소득 감소율 99

〈표 4-26〉 심층인터뷰 조사 계획 101

〈표 4-27〉 심층인터뷰 참여자 현황 102

〈표 4-28〉 심층인터뷰 질의 내용 103

〈표 4-29〉 심층인터뷰 조사 결과 126

〈표 5-1〉 정부의 고용유지지원 제도 145

〈표 5-2〉 업종별 주요 교육현황(2021년) 151

〈표 5-3〉 문화체육관광부의 주요 관광 인력 교육 프로그램(2021년) 152

〈표 5-4〉관광 부문 주요 자격증 현황 153

〈표 5-5〉 관광산업 고용관련 통계 현황 154

〈표 5-6〉 문화체육관광부 인력 실태조사 현황 155

〈표 5-7〉 종사자 보호를 위한 법령 제정 현황 157

〈표 5-8〉 근로계약서 서면작성 비율 158 


\section{그림 목차}

[그림 1-1] 감염병 확산이 관광분야에 미치는 영향 3

[그림 1-2] 관광사업체 수와 종사자 수 추이 4

[그림 1-3] 관광사업체 종사자 현황 5

[그림 2-1] 사회안전망의 범위 11

[그림 2-2] 고용형태별 고용보험의 법적·실질적 사각지대 개념 14

[그림 2-3] 고용안전망 확충 과정 15

[그림 2-4] 포용국가 사회정책 추진계획 중 고용안전망 정책 17

[그림 2-5] 중층적 고용안전망 구축 20

[그림 2-6] 우리나라 노동시장 현황 21

[그림 2-7] 전국민 고용보험 로드맵 22

[그림 2-8] 산재보험 적용 직종(특고) 유형 분류 24

[그림 3-1] 조선업 특별고용지원대책 구조 37

[그림 3-2] 예술인 고용보험 적용대상 39

[그림 3-3] OECD 국가의 코로나19 대응 조치 43

[그림 3-4] 전 세계 코로나19 관광분야 위기 대응 조치 60

[그림 3-5] 코로나19 위기 대응을 위해 스위스 호텔에서 취한 조치 63

[그림 3-6] 향후 필요한 정책 및 조치에 대한 의견 64

[그림 4-1] 관광사업체 종사자 업종별 구성비 72

[그림 4-2] 관광사업체 고용형태별 종사자 수 구성비 추이 73

[그림 4-3] 전년 대비 무급 및 유급 휴직자수 변화 76

[그림 4-4] 전년 대비 피보험자 증감률(\%) 81

[그림 4-5] 전년 대비 피보험 상실자 증감률(\%) 83

[그림 4-6] 전년 대비 실업급여 수급자격인정자 증감률(\%) 84

[그림 4-7] 전년 대비 실업급여 지급인원 증감률(\%) 85

[그림 4-8] 업종별 고용유지지원금 집행액 92

[그림 4-9] 고용유지지원금 지원 사업체 및 종사자 현황 93

[그림 4-10] 고용유지지원금 수혜 업종 피보험자 수 증감률 비교 93 
[그림 4-11] 신청자 연령별 분포 97

[그림 4-12] 소득구간 분포: 직종별 98

[그림 4-13] 소득감소율 분포: 직종별 99

[그림 4-14] 여가 및 관광 관련 종사원 소득 현황 100

[그림 4-15] 여가 및 관광 관련 종사원 근무 기간 100

[그림 4-16] 관광산업 고용안전망 사각지대 결과 131

[그림 5-1] 2019년 기준 업종별 입직률 및 이직률 136

[그림 5-2] 주요 특별고용지원업종 생산지수 및 피보험자수 감소 현황 136

[그림 5-3] 연령별 종사자 분포 137

[그림 5-4] 관광통역안내사 대상 설문조사 결과 140

[그림 5-5] 전국민 고용보험가입 비중 추산 결과 141

[그림 5-6] 2019년 기준 호텔업 종사자 고용형태(객실 종사자 기준) 147

[그림 6-1] 우리나라의 플랫폼 노동시장 167 

관광산업 고용안전망 구축방안

제1장

서론 



\section{제1절 연구배경 및 목적}

\section{1. 연구배경}

\section{가. 코로나19 위기는 관광산업의 일자리 위기로 확산}

코로나19로 인한 관광산업의 피해는 고용 불안과 일자리 위기로 이어져 산업 생태계 를 위협하고 있다. 관광산업이 경제의 중요한 축으로 지역경제에서 차지하는 비중이 높 을수록 일자리 위기에 대한 우려도 높게 나타나고 있다.

코로나19 위기 상황에서 정부의 정책 지원이 우선되어야 할 부분은 '고용 유지'이다. 취약한 고용안전망을 확충하는 일은 고용위기에 대응하는 능력을 갖추고, 경제의 활력 제고와 일자리 창출 및 고용의 질 향상을 위해서도 시급한 과제이다(김용기, 2020). 이 때문에 세계 각국 정부는 코로나 19 초기 대응으로 고용유지제도 등을 시행하여 고용 충 격에 대비하고 있다(OECD, 2020).

우리나라 역시 코로나19의 영향으로 사회·경제적 대전환이 예상되며, 관광행태 변화 에서부터 관광시장, 관광산업 등 다양한 분야에서 새로운 질서가 형성되면서 관광일자리 와 노동시장도 많은 변화가 예상된다. 특히 코로나19 영향이 지속되면서 관광산업 종사 자의 휴직, 실업이 증가하는 반면, 관광산업의 디지털 전환이 가속화되면서 기술기반형 일자리 수요의 증가가 예상된다.

[그림 1-1] 감염병 확산이 관광분야에 미치는 영향

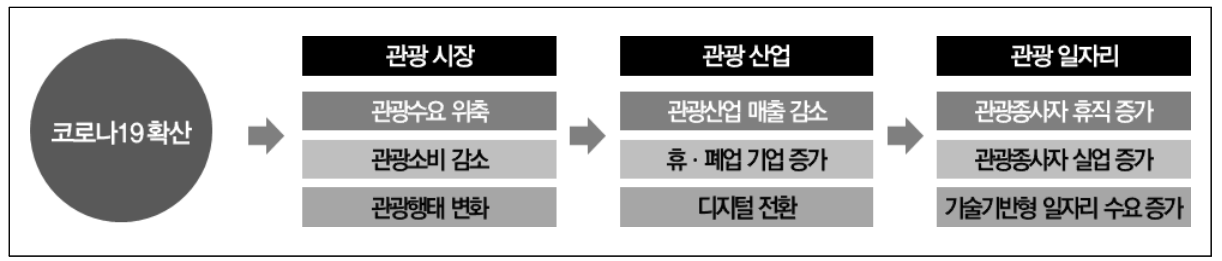

자료: 김현주(2020). 코로나19가 가져온 관광산업 영향과 향후 전망, 문화관광 인사이트 제151호. 


\section{나. 전국민 고용보험 등 고용안전망 확충에 대한 정책 논의 본격화}

정부는 ‘혁신적 포용국가 구현', '사람중심 경제로의 전환’의 기조 아래 범정부 차원의 「한국판 뉴딜 종합계획」을 발표하고, 디지털뉴딜과 그린뉴딜, 고용·사회안전망 강화를 제시하였다. 이 중 안전망 강화는 "경제구조 재편 등에 따른 불확실성 시대에 실업불안 및 소득격차를 완화하고 적응을 지원하여 경제주체의 회복력을 강화”하는 것이다.

코로나19로 인한 고용위기 상황에서 고용보험제도가 실질적으로 다수의 일하는 사람 을 법적 사각지대에 방치한다는 점이 부각되면서, '전국민 고용안전망 구축'이 국가 아 젠다로 논의되고 있다. 고용안전망 구축 관련 각 분야별 구체적인 논의가 요구되며, 플 랫폼 노동자 증가 등 변화하는 노동환경을 포괄하는 새로운 형태의 노사관계, 근무방식 등을 고려한 제도 설계를 위해서는 충분한 사회적 합의가 필요한 상황이다(김용기, 2020). 특히, 기업의 고용 관행, 비즈니스 모델의 다양화, 청년실업 문제 및 고령화 등 급변하는 노동시장 변화에 대응하기 위해서는 고용안전망 확충 및 강화가 중요한 정책 수단으로 논의된다(김근주, 2020).

\section{다. 관광산업의 질적 성장을 위한 고용(일자리) 정책의 중요성 제기}

관광산업은 사업체 수와 종사자 수는 꾸준히 증가하고 있으나, 사업체당 평균 종사자 수와 종사자 1 인당 매출액은 감소 추세를 보이고 있다. 관광산업 내부의 근로환경, 노동 시장의 질적 측면에 대한 개선 필요성이 제기되는 지점이다.

[그림 1-2] 관광사업체 수와 종사자 수 추이

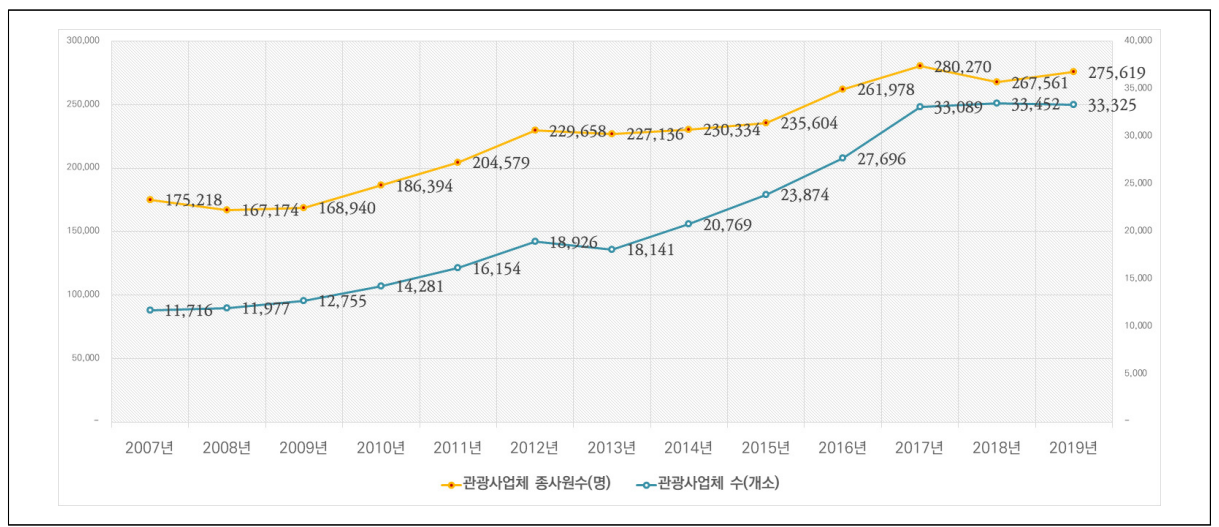

자료: 문화체육관광부 한국문화관광연구원(각 년도). 관광사업체조사 
관광산업은 대표적인 노동집약산업임에도 불구하고, 종사자들의 근로환경 및 조건에 관한 정책적 논의는 크게 주목받지 못하고, 노동 관련 이슈는 대부분 고용의 관점, 즉 관광산업 활성화로 인한 고용창출 효과에 집중되어 왔다(이경희·김근주, 2019).

관광산업 고용안전망 구축은 인적 서비스를 바탕으로 한 관광산업의 경쟁력과 직결되 며, 양질의 인적자원 확보를 위해서도 반드시 필요한 과제이다. 고품질의 관광서비스 제 공은 관광산업 종사자가 충분히 존중받을 수 있는 노동조건에서 가능하며, 관광산업 종 사자의 노동권이 보장될 때 인적 서비스를 기반으로 하는 관광산업의 지속가능한 발전 이 가능하기 때문이다(이경희·김근주, 2019).

[그림 1-3] 관광사업체 종사자 현황

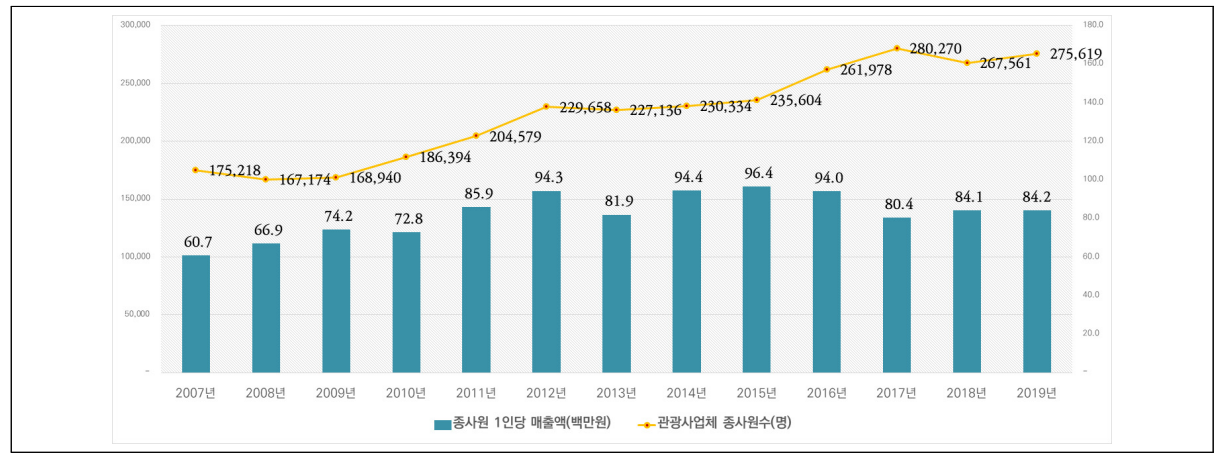

자료: 문화체육관광부·한국문화관광연구원(각 년도). 관광사업체조사

\section{라. 관광산업의 고용안전망 사각지대 파악과 향후 정책 대응을 위한 전략 필요}

코로나19로 위기에 놓인 관광기업 지원을 위하여 정부는 관광업을 '특별고용지원업 종' 으로 지정하고, 고용유지지원금 등 다양한 지원 정책을 추진하였다. 코로나 19 가 장기 화 되는 현 시점에서 과연 고용지원정책이 산업에 어떠한 역할을 하고 있는지에 점검이 필요하다. 사업주는 고용위기 상황에서 고용유지지원금을 통해 고용을 유지하는 대신 무 급휴직, 권고사직을 실시하는 경우가 적지 않기 때문이다(정흥식, 2020).

'관광산업 영역에서 현재의 고용안전망으로 보호하지 못하고 있는 사람들은 누구이 며, 이들에게 필요한 고용안전망은 무엇이지, 어떻게 만들어야 하는가?' 가 본 연구의 주 요 문제인식이다. 코로나19는 고용 정책에서 관광산업 내 사회적 보호가 필요한 사각지 대를 확인하는 계기가 되었다. 정부의 고용 지원 정책이 미치지 않는 사각지대에 대한 점검이 필요하며, 향후 정부의 정책 환경 변화에 대응한 방향과 전략 모색이 요구된다. 


\section{2. 연구 목적}

본 연구는 관광산업의 고용 현황과 실태를 파악하고, 고용안전망의 사각지대를 진단 하여, 향후 정책 환경 변화에 대응한 관광산업 고용안전망 구축 방향과 과제를 도출하는 데 목적을 둔다. 연구의 세부 목적은 다음과 같다.

첫째, 관광산업 고용 현황과 노동시장의 특징을 분석하고, 코로나 19 이후의 변화를 분석한다.

둘째, 관광산업의 특성을 고려한 고용안전망의 정책 대상과 범위를 설정하고, 현재의 고용안전망에서 소외된 사각지대의 실태 파악을 통하여 지원방안을 제시한다.

셋째, 코로나19 이후 관광산업 환경 변화를 고려한 관광산업 고용안전망 구축 방향과 정책과제를 도출한다. 


\section{제2절 연구범위 및 방법}

\section{1. 연구 범위}

\section{가. 시공간적 범위}

본 연구에서는 2020년을 시간적 기준으로 설정하였다. 다만, 통계자료 공표 시기로 인하여 관광산업 고용실태 분석 자료는 2019년을 기준으로 분석하였다. 공간적 범위는 전국을 대상으로 한다.

\section{나. 대상적 범위}

이 연구의 대상적 범위는 관광산업 종사자이다. 세부적으로는 관광산업 고용안전망의 사각지대에 있는 취약계층을 규명하는데 목적을 두고 있으므로, 사각지대를 주된 대상적 범위로 설정하였다.

\section{다. 내용적 범위}

연구의 내용적 범위는 다음과 같다.

첫째, 고용안전망의 개념과 정책 동향 분석

둘째, 고용안전망 구축 관련 제도 및 국내외 시례 분석

셋째, 관광산업의 고용안전망 실태 분석 및 진단

- 관광산업 고용 현황 및 노동시장 특성 분석

- 업종·직종별 고용안전망 실태 파악

- 관광산업 고용안전망 사각지대 현황 파악

- 관광산업 고용안전망 사각지대 대상 규명

넷째, 관광산업 고용안전망 구축방향과 정책과제 제시 
- 관광산업 고용안전망 사각지대 해소를 위한 추진전략 제시

\section{2. 연구 방법}

연구방법은 문헌연구, 사례분석, 통계자료 분석, 심층인터뷰조사와 전문가 자문을 진 행하였다. 고용안전망 구축 방안 마련을 위해서는 사각지대 파악이 선결되어야 한다. 이 연구는 관광산업 고용안전망 사각지대 분석 및 실태 파악을 위하여 두 가지 방법을 적용 하였다. 첫째, 문화체육관광부, 고용노동부, 통계청에서 생산하는 통계자료를 활용하여 종사자 현황, 코로나 19 이후의 변화 등을 파악하였다. 관광산업 종사자 현황 파악을 위 하여 타 산업과의 비교를 통해 특성을 도출하는데 주안점을 두었다.

둘째, 현재까지 관광산업 고용안전망 사각지대를 개념화한 선행연구가 미흡한 상황으 로, 탐색적 접근을 진행하였다. 사각지대의 지형이 명확히 설명되지 않은 상태에서 양적 분석은 한계가 있다고 판단하고 탐색적 접근을 통하여 사각지대를 규명하고자 심층 인 터뷰 조사를 실시하였다. 심층인터뷰 조사는 업종별, 직종별 특성을 고려하여 진행하였 다. 현재 사각지대로 검토되는 관광가이드(관광통역안내사, 국외여행인솔자)를 포함하 여, 여행업, 관광숙박업, 국제회의기획업 종사자를 대상으로 진행하였다. 인터뷰 대상은 종사자 뿐 아니라 경영지원 부서(팀장급), 협회 관계자 등을 포함하여 관점의 차이를 살 펴보고 균형 있는 연구 결과 도출에 기여하고자 하였다.

〈표 1-1〉 연구방법

\begin{tabular}{|c|c|}
\hline 구분 & 세부 내용 \\
\hline 문헌연구 & $\begin{array}{l}\text { - 기존 선행연구 고찰을 통한 정부 정책 및 주요 계획 내용 분석 } \\
\text { - 최근 고용정책의 변화와 전망, 고용안전망 관련 제도적 변화를 체계적으로 검토 }\end{array}$ \\
\hline 사례분석 & $\begin{array}{l}\text { - 국제기구 및 주요국에서 논의되는 고용안전망 관련 사례 분석 } \\
\text { - 코로나19 이후 고용안전망 확충 정책 대응 등을 폭넓게 검토 }\end{array}$ \\
\hline $\begin{array}{l}\text { 통계 자료 분석 } \\
\text { (2차 자료) }\end{array}$ & $\begin{array}{l}\text { - 고용관련 각종 통계자료 분석을 통해 관광산업 고용시장 현황 파악 } \\
\text { - 관광사업체조사, 고용보험통계, 경제활동인구조사 등 분석 } \\
\text { - 긴급고용안정지원금 수급자 현황 자료 분석 등 }\end{array}$ \\
\hline 심층인터뷰조사 & $\begin{array}{l}\text { - 관광사업체 종사자, 고용안전망 취약계층 대상 심층인터뷰 조사 } \\
\text { - 인터뷰조사 대상 : 여행업, 관광숙박업, 국제회의기획업 종사자 등 }\end{array}$ \\
\hline 전문가 자문 & $\begin{array}{l}\text { - 관광산업 고용안전망 구축 정책과제 발굴 및 대안 제시를 위한 전문가 자문 } \\
\text { - 고용정책(노동), 관광, 사회복지 등 관련 분야 전문가 자문 진행 }\end{array}$ \\
\hline
\end{tabular}


관광산업 고용안전망 구축방안

제2장

고용안전망의 개념 및 정책 동향 



\section{제1절 고용안전망의 개념과 정책 범위}

\section{1. 고용안전망의 개념}

고용안전망은 실업 등 고용 위기에 대응하는 사회적 안전망으로, 일하는 사람을 촘촘 하고 탄탄하게 보호하는 역할을 한다. 실직, 산업재해, 질병 등 사회적 고용상의 위험으 로부터 사람들을 안전하게 보호하는 법률과 제도 등 체계를 말한다(김근주, 2020).

고용안전망은 사회안전망에서 고용과 관련된 부분으로 볼 수 있다. 사회안전망이 노 령·질병·실업·산업재해 등 사회적 위험으로부터 국민의 생존과 기초생활을 보장하는 제 도인 반면, 고용안전망은 실업 위험에 대한 안전망으로 사회안전망의 하위 개념으로 이 해할 수 있다(이병희, 2010). 사회안전망은 1차 3차 안전망으로 구분하는데 이는 수혜 자의 대비 능력에 따른 순차적인 안전장치로, 근로소득이 있고 보험료를 납부할 수 있는 사람들의 위험을 대비하는 1 차 안전망인 사회보험에서부터 노동능력과 소득, 자산이 없 는 사람들을 위한 3차 안전망인 각종 사회복지 프로그램 등이 사회안전망을 구성한다(이 상동, 2009). 사회보험제도는 질병, 장애, 노령, 실업, 사망 등 사회적 위험을 보험을 통해 대처함으로써 국민의 건강과 소득을 보장하는 제도로, 우리나라의 4대 사회보험제 도는 업무상의 재해에 대한 산재보험, 질병과 부상에 대한 건강보험, 노령·장애·사망 등 에 대한 국민연금, 실업에 대한 고용보험제도가 있다.

[그림 2-1] 사회안전망의 범위

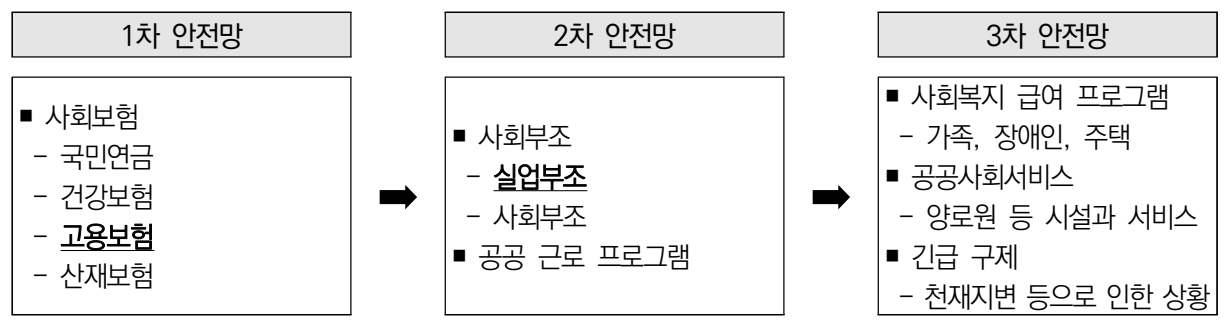

자료: 이상동(2009). 
사회안전망은 사회보험제도를 의미하는데, 고용안전망은 실업급여를 통한 소득 지원 뿐만 아니라 사회안전망에서 제외되는 적극적 노동시장정책(active labor market policy), 근로유인 보상정책(make work pay policy), 사회서비스 등을 포함한다는 점 에서 차이가 있다(이병희, 2010).

이러한 고용보험제도를 1 차 고용안전망으로 분류하며, 고용을 통하여 생활의 안정을 유지하고, 실업의 상태에서 다른 일자리로 원활하게 이동할 수 있도록 지원하는 사회시 스템을 강화하고 있다(장지연 외, 2011). 거시적 안전망은 고용의 유지, 창출 그리고 신 규 진입 또는 복귀 등을 위한 안전망으로, 소득 지원 뿐 아니라 재취업과 일자리 지원 등을 포함하며, 실업부조, 공공일자리 사업 등을 2차 3차 고용안전망으로 구분한다.

2020년 정부가 발표한 전 국민 고용보험은 고용안전망 구축의 전환점으로 의미하는 바가 크다. 전 국민 고용보험은 노동시장의 변동성, 고용형태의 다양화에 대응하여 일하 는 사람 모두에게 실업 위험에 대응한 소득 지원뿐만 아니라 적합한 일자리 선택, 더 나은 일자리로 이행, 실직 예방, 취업취약계층의 고용 촉진, 취업능력 제고, 일-생활 균 형을 지원하는 폭넓은 개념으로 볼 수 있다(이병희, 2020).

앞서 살펴본 고용안전망의 개념적 논의를 종합하여 본 연구에서는 고용안전망의 개념 을 '노동시장 위험에 대한 안전망' 으로 보고, 1차 안전망으로 분류하는 '고용보험제도'를 중심으로 연구를 진행하였다.

\section{2. 고용안전망 사각지대}

1995년 시행된 고용보험제도는 현재 우리나라 고용안전망의 핵심적인 역할을 담당하 고 있다(장지연 외, 2011). 고용보험은 근로자를 사용하는 모든 사업 또는 사업장에 적 용하는 것을 원칙으로 한다. 따라서 사업이 개시되어 고용보험의 적용요건을 충족하게 되었을 때 사업주나 근로자의 가입 의사와 관계없이 자동적으로 보험관계가 적용된다. 1998년 10월에 고용보험이 1인 이상 사업으로 확대되면서 적용 대상이 지속적으로 확 대되어 왔음에도 불구하고 고용보험이 적용되지 않는 취업자가 존재하는데, 이들을 법제 도적 사각지대로 정의한다. 사업주·자영업자와 무급가족종사자와 같은 비임금근로자와 임금근로자 중 적용이 제외되는 집단도 법제도적 사각지대에 속한다. 고용보험제도 적용 
제외자는 공무원, 교원, 별정우체국 직원, 고용보험에 가입하지 않으면서 5인 미만 농림 어업, 가구 내 고용활동, 65세 이상 신규입사자, 주당 소정근로시간이 15 시간 미만인 단시간 근로자( 3 개월 이상 근속한 근로자, 근로계약기간이 1 개월 미만이거나 1 개월 미 만 근속한 일용근로자는 제외), 특수형태근로에 종사하는 근로자를 포함한다. 현재 특수 직역연금이나 국민연금 등 다른 사회보장체계의 보호를 받을 수 있는 근로자 집단을 제 외하면, 2020년 기준 특수형태근로종사자, 초단시간 근로자, 가구 내 고용활동자는 고 용보험 적용이 제외되는 주요한 취약 계층이다(김근주, 2020).

〈표 2-1〉2019년 취업자 대상 고용보험 사각지대1)

\begin{tabular}{|c|c|c|c|c|}
\hline \multicolumn{5}{|c|}{ 취업자 } \\
\hline \multirow[b]{2}{*}{ 비임금 근로자 } & \multicolumn{4}{|c|}{ 임금 근로자 } \\
\hline & $\begin{array}{c}\text { 고용보험 적용제외 } \\
\text { 임금근로자 }{ }^{2)}\end{array}$ & $\begin{array}{c}\text { 고용보험 미가입 } \\
\text { 임금근로자 }\end{array}$ & 공무원 등 & $\begin{array}{c}\text { 고용보험 가입 } \\
\text { 임금근로자 }\end{array}$ \\
\hline $\begin{array}{l}\text { 6,799천명 } \\
(24.9 \%)\end{array}$ & $\begin{array}{l}\text { 1,781천명 } \\
\text { (6.5\%) }\end{array}$ & $\begin{array}{l}\text { 3,781천명 } \\
(13.8 \%)\end{array}$ & 1,469천명 & 13,528천명 \\
\hline \multicolumn{2}{|c|}{ 법제도적 사각지대 } & 실질적 사각지대 & & \\
\hline
\end{tabular}

주1 : 경제활동인구 근로형태별 부가조사(2019.8) 결과 기준

주2 : 5인 미만, 농림어업, 가사서비스업, 65 세 이상, 15 시간 미만+3개월 미만, 특수고용 자료: 이병희(2020). KLI 고용브리프 제95호

고용보험에 가입된 사람은 실업급여 뿐 아니라 적극적 노동시장정책의 대상으로 포함 되지만 그렇지 않은 사람은 배제될 가능성이 매우 크다. 이렇게 배제된 대상, 즉 고용보 험의 사각지대에 놓여있는 대상은 비정규직이나 소규모사업장 종사자, 영세자영업자, 노 동시장에 최초로 진입한 청년층, 장기간 경력이 단절되었던 미취업자 등이 해당된다. 이 들은 고용의 불안정성이 가장 큰 집단임에도 불구하고, 고용안전망에서 배제되어 있다는 것이 문제점으로 지적되어 왔다(장지연 외, 2011). 
[그림 2-2] 고용형태별 고용보험의 법적·실질적 사각지대 개념

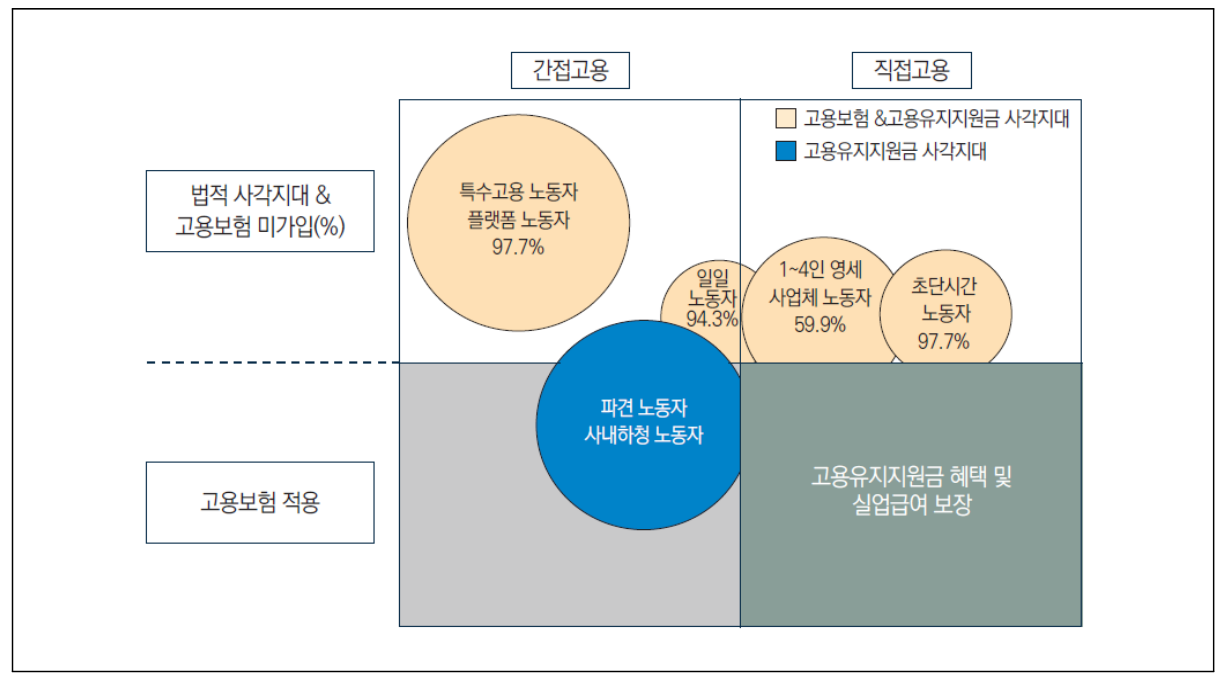

자료: 정흥준(2020). 코로나19, 사회적 보호 사각지대의 규모와 대안적 정책방향

고용보험은 실업급여 제공을 통해 근로자의 실직 위험으로부터 안전망 역할을 한다. 우리나라의 실업급여 수급 요건은 이직 전 18 개월 동안 피보험단위기간 180 일 이상 적 용사업의 피보험자로 고용되어, 임금을 목적으로 근로를 제공한 경력이 있어야 하고, 정 당한 이유 없이 자발적으로 이직하거나 자신의 중대한 귀책사유로 인하여 해고된 것이 아니어야 하며, 근로의 의사와 능력이 있음에도 불구하고 취업하지 못하고 있고, 적극적 인 구직 노력 등의 요건을 충족하여야 한다(김근주, 2020). 일용직은 수급자격 신청일 이전 1 개월간 근로한 일수가 10 일 미만이어야 하며 자영업자는 최소한 1 년의 피보험기 간이 있어야 수급 가능하다. 고용보험 $\mathrm{DB}$ 분석에 따르면, 우리나라는 자발적 이직자의 비율이 높기 때문에 고용보험 가입 이직자 중 실업급여 수급자 비율은 $20 \%$ 에 불과하다 (김근주, 2020). 따라서 고용보험에 가입되었다 하여도 실제로 실업급여 등 고용안전망 을 구성하는 제도의 혜택과 지원을 적용받는가를 파악하는 것이 필요하며, 실질적인 사 각지대 이해의 중요한 부분이다. 


\section{3. 고용안전망의 정책 범위}

전통적인 고용안전망은 실업보험 및 실업부조라고 할 수 있으나, 최근에는 실업의 장 기화를 방지하고 저숙련 근로자가 저임금. 불안정 근로에서 벗어날 수 있도록 국가가 적극적으로 취업알선과 직업훈련 서비스를 제공하는 등 고용안전망의 범위가 확대되고 있다(국회예산정책처, 2019). 특히, 코로나19로 인한 일자리 위기(갑작스런 실업, 경기 불황, 미래혁명 가속, 산업·직업변화)로 고용안전망 강화의 필요성이 제기되면서 고용보 험의 단계적 확대(임금노동자, 예술인, 특고, 플랫폼 노동자, 프리랜서, 자영업자), 저소 득 실업자를 대상으로 국민취업지원제도 도입이 추진되면서 고용안전망의 정책 범위가 확대되어 왔다. 적극적 노동시장 정책으로는 고용유지와 신규고용 촉진을 위한 각종 지 원프로그램, 청년과 장기실업자를 위한 구직활동 프로그램, 여성과 단시간 노동자들의 고용을 안정화시키기 위한 프로그램 등이 추진되어 왔다.

[그림 2-3] 고용안전망 확충 과정

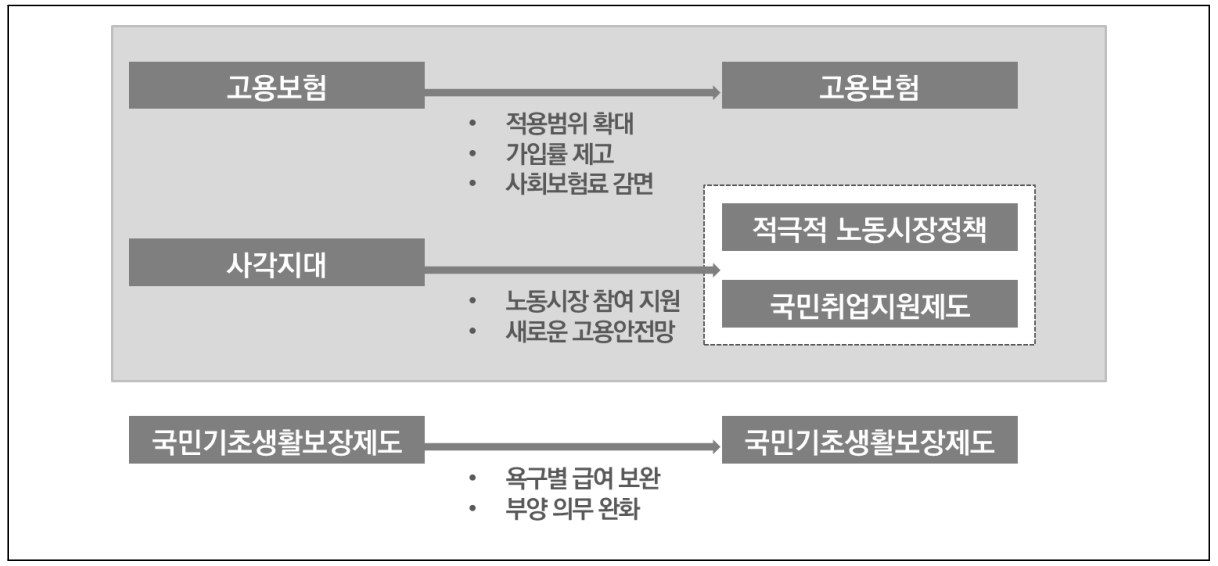

자료: 허재준(2020).

지난 20년간 고용보험을 중심으로 한 고용안전망의 정책 성과로 고용보험 가입률은 크게 증가하였으나, 노동시장 취약계층으로 이루어진 사각지대는 획기적으로 줄어들지 않았다는 평가를 받는다. 특히, 디지털 기술을 활용한 플랫폼 노동의 출현 등으로 미래 노동시장에서는 '전통적 고용계약 형태를 띠지는 않지만 인적용역 형태를 띠는 계약으로 서 경제적 종속성이 강한 계약이 증가할 것으로 예상된다(허재준, 2020). 
노동시장의 변화에 대응하며, 고용안전망이 충분히 작동하기 위해서는 정부 차원의 고용 서비스와 정책 지원이 중요하다. 고용안전망은 초기의 단순히 실업수당을 지급하는 것에서 나아가 실업을 사전적으로 차단하기 위한 적극적 노동시장 정책을 강화해 왔다. 이러한 적극적 노동시장 정책이 강조된 이유는 고용 불안이 일상화되고 청년실업과 장 기실업이 사회문제가 되었기 때문이다. 앞으로 디지털 경제로 본격 진입하게 된다면 더 욱 급격한 노동시장 변화가 야기될 것이고, 이에 대응하기 위해서는 촘촘한 고용안전망 구축을 위한 정부의 역할이 더욱 강조될 것으로 예상된다. 


\section{제2절 고용안전망 관련 정책 동향}

\section{1. 포용국가 사회정책과 고용안전망}

\section{가. 포용국가 사회정책 추진계획}

문재인 정부는 '실직과 은퇴에 대비하는 일자리 안전망 강화'를 국정과제로 제시하고, 중층적 고용안전망 체계 구축을 방향성으로 제시하였다. 고용보험의 가입 대상 확대와 중층적 고용안전망 구축은 노동정책의 기조로 현재까지 지속되고 있다(김근주, 2020).

〈표 2-2〉 국정과제 - 일자리 안전망 강화 세부 과제

(1) 자영업자 고용보험 가입요건을 사업자등록일로부터 1년 이내에서 5년 이내로 완화

(2) 구직급여 소정 급여일수 30 일 확대 및 지급수준 $60 \%$ 로 인상

(3) 65 세 이상 및 초단시간 근로자의 실업급여 수급요건을 완화

(4) 특수형태근로종사자·예술인 고용보험 적용

(5) 적용 제외되고 있는 가사근로자는 서비스 제공기관의 직접 고용을 지원하여 고용보험 가입 유도

(6) 한국형 실업부조, 청년구직활동지원금 등 보완적 고용안전망 도입

이는 2019년 정부가 발표한 「포용국가 사회정책 추진계획」에서 재확인되는데, 고용 안전망 확충 과제로 (1) 한국형 실업부조 도입 등 중층적 고용안전망 확충, (2) 고용보험 가입 대상 확대 및 가입 지원, (3) 실업급여 보장성 강화를 제시하였다.

[그림 2-4] 포용국가 사회정책 추진계획 중 고용안전망 정책

\begin{tabular}{|c|c|c|c|c|}
\hline 정책목표1 & \multicolumn{4}{|c|}{ 고용안전망에서 배제된 국민들의 안정적인 소득을 보장하겠습니다. } \\
\hline $\begin{array}{l}\text { 2022년의 } \\
\text { 달라진 삶 }\end{array}$ & \multicolumn{4}{|c|}{ 실업부조가 시행되어 근로빈곤층의 생계가 보장되고, 재취업이 원활해집니다. } \\
\hline & 주요과제 & 성과지표 & 2018년 & 2022년 \\
\hline \multirow{3}{*}{\multicolumn{2}{|c|}{$\begin{array}{l}11 \text { 한국형 실업부조 도입 등 중층적 고용안전 } \\
\text { 망 구축 } \\
2 \text { 고용보험 가입대상 확대 및 가입 지원 } \\
3 \text { 실업급여 보장성 강화 }\end{array}$}} & $\begin{array}{c}\text { 한국형 실업부조 } \\
\text { 도입/적용대상 }\end{array}$ & $\begin{array}{c}\text { 취업성공패키지 } \\
\text { 30만명 }\end{array}$ & $\begin{array}{l}\text { 실업부조 } \\
\text { 50만명 }\end{array}$ \\
\hline & & 고용보험 피보험자 규모 & 1,343 만명 & 1,500 만명 \\
\hline & & $\begin{array}{c}\text { 실업급여 지급 수준 } \\
\text { 및 지급기간 }\end{array}$ & $\begin{array}{c}50 \% \\
\text { (최대 240일) }\end{array}$ & $\begin{array}{c}60 \% \\
\text { (최대 270일) }\end{array}$ \\
\hline
\end{tabular}

자료: 관계부처 합동(2019.2.19.) 문재인 정부「포용국가 사회정책 추진계획」 


\section{나. 한국판 뉴딜 종합계획}

고용안전망 강화는 「한국판 뉴딜 종합계획」에도 반영되어, 고용·사회 안전망 강화를 발표하였다. 정부는 코로나19 위기를 극복하고, 선도국가로 도약하기 위한 국가발전 전 략으로 ‘한국판 뉴딜 종합계획’을 발표(2020.7.14.)하였다. 한국판 뉴딜 종합계획은 고 용·사회안전망을 구축하여 고용형태 다양화와 경제·산업구조 재편 시 발생할 수 있는 고용 불안을 완화하고, 혁신의 토대인 사람중심 투자를 통해 미래형 인재를 양성하여 디지털·그린 일자리로의 인력 재배치 지원 등을 포함하고 있다.

〈표 2-3〉 한국판 뉴딜 종합계획 - 고용·사회 안전망 강화

\begin{tabular}{|c|c|}
\hline 구분 & 내용 \\
\hline (1) 전 국민 고용안전망 구축 & $\begin{array}{l}\text { (고용보험) 예술인·특고에 대해 단계적으로 지원대상 확대 } \\
\text { (산재보험) 특고 지원 직종 확대 }(9 \rightarrow 14 \text { 개 })\end{array}$ \\
\hline (2) 포용적 사회안전망 강화 & $\begin{array}{l}\text { (기초생활보장) 생계급여 부양의무자 기준 폐지, 보장성 강화 } \\
\text { (상병수당) 한국형 상병수당 도입 추진, 저소득층 대상 시범사업 }\end{array}$ \\
\hline $\begin{array}{l}\text { (3) 고용보험 사각지대 생활·고용안정 } \\
\text { 지원 }\end{array}$ & $\begin{array}{l}\text { (국민취업지원제도) 저소득 근로빈곤층 대상 직업훈련, 일경험 등 } \\
\text { 취업 지원프로그램 지원, 구직촉진수당(월50만원 } \times 6 \text { 개월)·취업성공 } \\
\text { 수당 지급 }\end{array}$ \\
\hline (4) 고용시장 신규진입·전환 지원 & $\begin{array}{l}\text { (청년) 청년 채용시 인건비 지원, 중소중견기업 핵심인력 매칭 } \\
\text { *청년 디지털 일자리 : 최대 6개월간 월 180만원, '21년 5만명 }\end{array}$ \\
\hline (5) 산업안전 및 근무환경 혁신 & 산재예방을 위한 정기기술지도, 안전보건지킴이 채용, 환경개선 등 \\
\hline
\end{tabular}

자료 : 관계부처 합동(2020.7.14.). 한국판뉴딜 종합계획

\section{다. 중층적 고용안전망 구축}

고용노동부는 '든든한 고용안전망 확충'을 목표로 고용보험제도 뿐 아니라 취업촉진 수당, 자영업자 고용보험 지원 등 다양한 정책 사업을 추진하고 있다(표 2-4).

‘중층적 고용안전망 구축' 은 고용보험과 국민취업지원제도가 상호 보완하여 실업자를 두텁게 보호할 수 있도록 한다는 것이다. 이를 위해 전국민 고용보험, 국민취업지원제도 도입 등 고용안전망 확대를 뒷받침하기 위해 공공고용서비스 인프라 강화를 추진한다. 2021년부터는 국민취업지원제도를 시행하여 기존 고용보험 사각지대에 있는 저소득층 과 청년 등에게 취업지원 서비스와 일정소득 지원을 포함한다. 
〈표 2-4〉 고용노동부 '든든한 고용안전망 확충' 정책 사업

\begin{tabular}{|c|c|}
\hline 구분 & 세부 내용 \\
\hline 고용보험제도 & $\begin{array}{l}\text { - 대상 : 근로자를 고용하는 모든 사업장 } \\
\text { - 개요 : 근로자(보수의 } 0.80 \% \text { )와 사업주(보수총액의 } 1.05 ~ 1.65 \%) \text { 가 공동 부담하여 마련한 } \\
\text { 기금으로 실업의 예방, 고용의 촉진 및 근로자의 직업능력개발.향상, 실직근로자의 생활안 } \\
\text { 정 및 재취업을 지원하는 사회보험제도 }\end{array}$ \\
\hline $\begin{array}{l}\text { 고용보험 } \\
\text { 피보험자격 } \\
\quad \text { 관리 }\end{array}$ & $\begin{array}{l}\text { - 개요 : 고용보험 가입대상 근로자의 피보험자격 취득과 상실 등의 엄격한 관리를 통해 실업 } \\
\text { 급여 등 고용보험사업 적정 운영 }\end{array}$ \\
\hline $\begin{array}{l}\text { 구직급여- } \\
\text { 연장급여 }\end{array}$ & $\begin{array}{l}\text { - 대상 : 이직일 이전 } 18 \text { 개월간 피보험단위기간 } 180 \text { 일 이상 근로하고, 회사의 경영상 해고 } \\
\text { 등 비자발적으로 이직, 상시 취업이 가능한 상태에서 적극적으로 재취업활동을 하는 사람 } \\
\text { - 개요 : 이직한 피보험자가 근로의 의사와 능력이 있음에도 취업하지 못한 상태에서 재취업 } \\
\text { 활동을 하는 기간에 생활안정 및 재취업 지원 }\end{array}$ \\
\hline 취업촉진수당 & $\begin{array}{l}\text { - 대상 : 구직급여 수급자 } \\
\text { - 개요 : 구직급여 수급자의 조기 재취업을 장려하기 위하여 조기재취업수당, 직업능력개발수 } \\
\text { 당, 광역구직활동비, 이주비 등의 인센티브를 제공함으로써 수급자의 장기실업 방지 및 재 } \\
\text { 취업 촉진 }\end{array}$ \\
\hline $\begin{array}{l}\text { 소규모사업장 } \\
\text { 저임금근로자 } \\
\text { 사회보험료 } \\
\quad \text { 지원 }\end{array}$ & $\begin{array}{l}\text { - 대상 : } 10 \text { 인미만 사업장에 근로하는 월보수 } 210 \text { 만원 미만의 근로자와 사업주 } \\
\text { - 개요 : 소규모사업장, 저임금근로자의 사회보험(고용보험·국민연금) 보험료 부담분의 일부를 } \\
\text { 지원, 사회보험 가입확대 및 사회안전망 강화 }\end{array}$ \\
\hline $\begin{array}{l}\text { 자영업자 } \\
\text { 고용보험 }\end{array}$ & $\begin{array}{l}\text { - 대상 : 본인 명의의 사업자등록증을 보유한, } 1 \text { 인 자영업자 또는 } 50 \text { 인 미만 근로자를 고용하 } \\
\text { 는 자영업자로 사업자등록일로부터 } 5 \text { 년 이내인 자 } \\
\text { - 개요 : 비자발적으로 폐업한 자영업자가 재취업·재창업활동을 하는 동안 실업급여 지급 및 } \\
\text { 직업훈련 지원을 통해 생활안정 및 재취업 지원 }\end{array}$ \\
\hline $\begin{array}{c}\text { 실업크레딧 } \\
\text { 지원 }\end{array}$ & $\begin{array}{l}\text { - 대상 : 국민연금 가입자 또는 기 가입자 중 } 18 \text { 세 이상 } 60 \text { 세 미만의 구직급여 수급자 } \\
\text { - 개요 : 실업자의 노후소득 보장을 강화하기 위해 구직급여 수급 기간 동안 국민연금 보험료 } \\
\text { 의 일부를 지원하고 그 기간을 연금 가입기간으로 산입 }\end{array}$ \\
\hline $\begin{array}{c}\text { 건설노동자 } \\
\text { 퇴직공제제도 }\end{array}$ & $\begin{array}{l}\text { - 대상 : 공사예정금액 } 3 \text { 억원 이상인 공공발주공사, } 100 \text { 억원 이상인 민간발주공사 등 } \\
\text { - 개요 : 사업주가 건설근로자를 피공제자로 하여 건설근로자공제회에 공제부금을 내고 그 } \\
\text { 피공제자가 건설업에서 퇴직하는 등의 경우에 건설근로자공제회가 퇴직공제금을 지급 }\end{array}$ \\
\hline $\begin{array}{l}\text { 건설일용근로자 } \\
\text { 기능향상 지원 }\end{array}$ & $\begin{array}{l}\text { - 대상 : 만 15 69세에 해당하는 자로서 고용보험 및 퇴직공제제도 가입이력자, 건설현장에 } \\
\text { 서 일한 유경험자 중심 } \\
\text { - 개요 : 건설업의 특성상 일이 없는 동절기 등에 건설기능훈련을 실시함으로써 건설일용근로 } \\
\text { 자의 직업능력 향상 및 생활안정을 지원 }\end{array}$ \\
\hline 산재보험제도 & $\begin{array}{l}\text { - 대상 : 근로자를 사용하는 모든 사업 또는 사업장, 특수형태근로종사자, 중·소기업사업주, } \\
\text { 현장실습생, 「국민기초생활 보장법」에 따른 자활급여 수급자 } \\
\text { - 개요 : 근로자의 업무상 재해에 대해 국가가 사업주로부터 소정의 보험료를 징수하여 그 } \\
\text { 기금으로 사업주를 대신하여 보상 }\end{array}$ \\
\hline 산재보험급여 & $\begin{array}{l}\text { - 대상 : 산업현장에서 업무상 재해를 당한 근로자등 } \\
\text { - 개요 근로자가 산업현장에서 업무상 재해를 당한 경우 사업주가 부담해야 할 재해보상 책 } \\
\text { 임을 국가가 대행하여 신속 공정한 보상으로 산재근로자 및 그 가족의 생활안정 도모 }\end{array}$ \\
\hline
\end{tabular}

자료: 고용노동부 정책자료 https://uww.moel.go.kr/policy/policyinfo/safety/list.do 
고용노동부의 정책은 고용보험, 기초생활보장제도 등 기존 고용안전망의 제도적 사각 지대 해소를 우선에 두고 있다. 실업급여는 고용보험 가입자가 비자발적으로 이직한 경 우 구직활동 기간 생활안정을 지원한다. 둘째 기초생활보장제도는 생활이 어려운 사람에 게 급여를 제공, 최저생계 보장 및 빈곤 탈출 지원(장애·가족부양 등의 이유로 근로능력 이 없는 대상을 주로 지원)이다. 마지막으로 국민취업지원제도는 근로능력·의사가 있으 나, 주로 고용보험의 혜택에서 소외된 저소득 구직자 등에 취업·소득지원을 제공하여 '일을 통한 자립'을 지원하는 것이다.

[그림 2-5] 중층적 고용안전망 구축

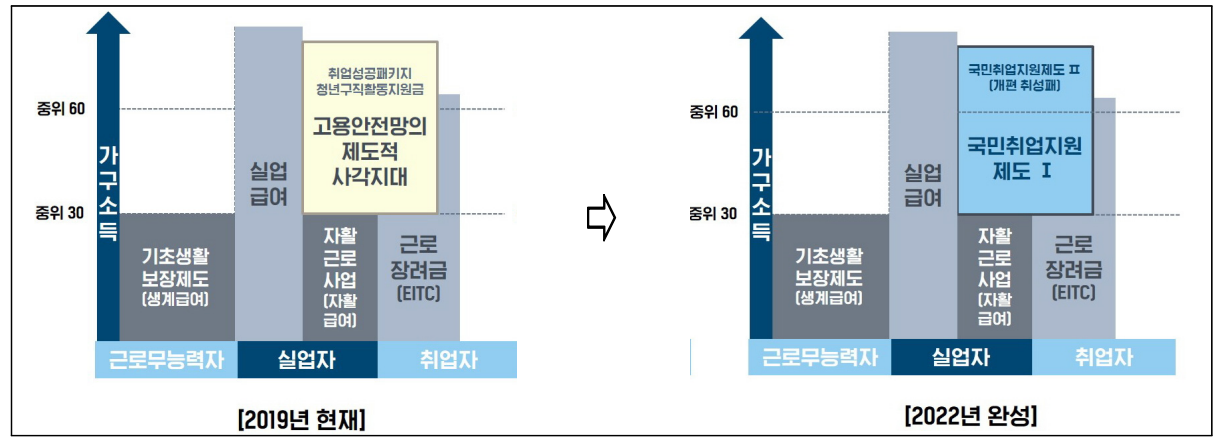

출처: 고용노동부

고용노동부는 2022년까지 국민취업지원제도 지원규모를 확대(60만명)하여, '국민취 업지원제도 완성을 목표로 하고 있다. 이를 통해 연간 235만명 이상을 지원하는 중층적 고용안전망 구축 계획을 발표하였다(2020.12.16.)

〈표 2-5〉2022년 우리의 고용안전망 모습

\begin{tabular}{|c|c|c|c|c|}
\hline \multirow{2}{*}{ 구분 } & 1차 안전망 & \multicolumn{2}{|c|}{ 2차 안전망 } & 3차 안전망 \\
\hline & 실업급여 & 국민취업지원제도 | & 국민취업지원제도 II & 재정지원 직접일자리 \\
\hline 대상 & $\begin{array}{l}\text { - 특고, 예술인 등 적 } \\
\text { 용 확대 추진 중 }\end{array}$ & $\begin{array}{l}\text { - 중위소득 30 50\% } \\
\text { 저소득층 } \\
\text { - 저소득 비경활, } \\
\text { 중위소득 } \quad 120 \% \text { 이 } \\
\text { 하 청년 }\end{array}$ & $\begin{array}{l}\text { - 국민취업지원제도 | } \\
\text { 의 지원을 받지 못 } \\
\text { 하는 폐업 영세자영 } \\
\text { 업자, 조건부 수급 } \\
\text { 자, 청년 등 }\end{array}$ & $\begin{array}{l}\text { - 1차, 2차 안전망의 } \\
\text { 지원을 받지 못하는 } \\
\text { 취약계층, 조건부 } \\
\text { 수급자 등 }\end{array}$ \\
\hline 연간규모 & 140 만명 $+\alpha$ & 50만명 & 10만명 & 35 만명 $+\alpha$ \\
\hline
\end{tabular}

출처: 고용노동부 보도자료(2020.12.16.) 


\section{2. 전국민 고용보험 로드맵}

\section{가. 추진배경}

노동시장의 구조적 전환기를 맞아 다양한 고용형태가 급증하고 있다. 4차 산업혁명으 로 디지털 전환 시대를 맞아 세계적으로 새로운 고용형태가 빠르게 등장-확산하면서, 불 안정 노동이 증가하고 종속노동과 자영업 간 경계가 모호해지는 현상이 확대되고 있다. 기존 근로자와 자영자의 이분법적 접근에서 벗어나 다양한 형태의 취업자에 대한 제도 적 보호가 요구되는 이유이다.

[그림 2-6] 우리나라 노동시장 현황

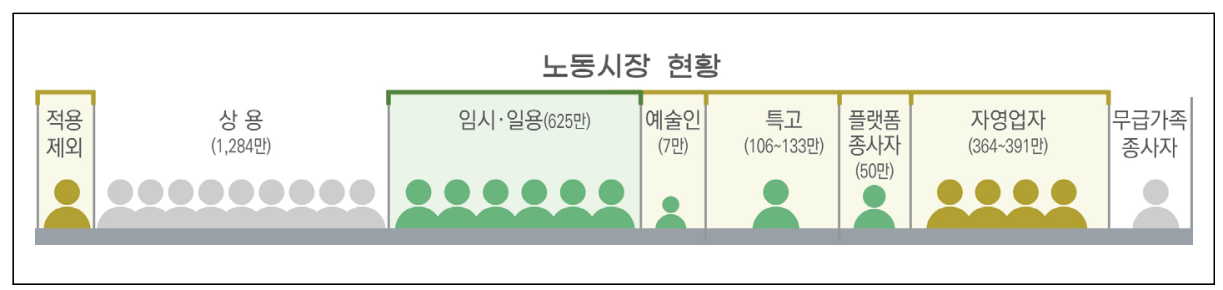

주 : 2020년 기준 고용보험 가입자 14,048 천명1)

출처: 고용노동부(2020.12.23.). 전국민 고용보험 로드맵

\section{나. 주요 내용}

전 국민 고용보험제도 구축은 모든 취업자가 가입할 수 있도록 소득정보 기반으로 고 용보험 체계 전면 개편하는 것을 골자로 한다. 소득기반 고용보험으로 전환이 갖는 의미 는 취업형태와 관계없이 일정 소득 이상인 일자리는 모두 고용보험 가입이 가능하며, 사각지대 없이 모두 적용된다는 것이다. 또한 정확한 소득정보 기반으로 운영되므로 거 래 투명성을 강화하여 가입자 간 공평한 기여가 보장된다.

1) 영세자영업자, 특수고용형태근로종사자 등 전체 취업자의 $45 \%$, 약 1,200 만명(2018년 기준)이 고용보험제 도 밖에 있는 상황이며, 자발적 이직, 피보험 기간 미충족 등의 사유로 고용보험에 가입된 이직자 중 실업급 여 수급자는 20\%수준(139만 명)이다(일자리위원회, 2019). 


\section{모든 취업자에게 보편적 고용안전망 제공}

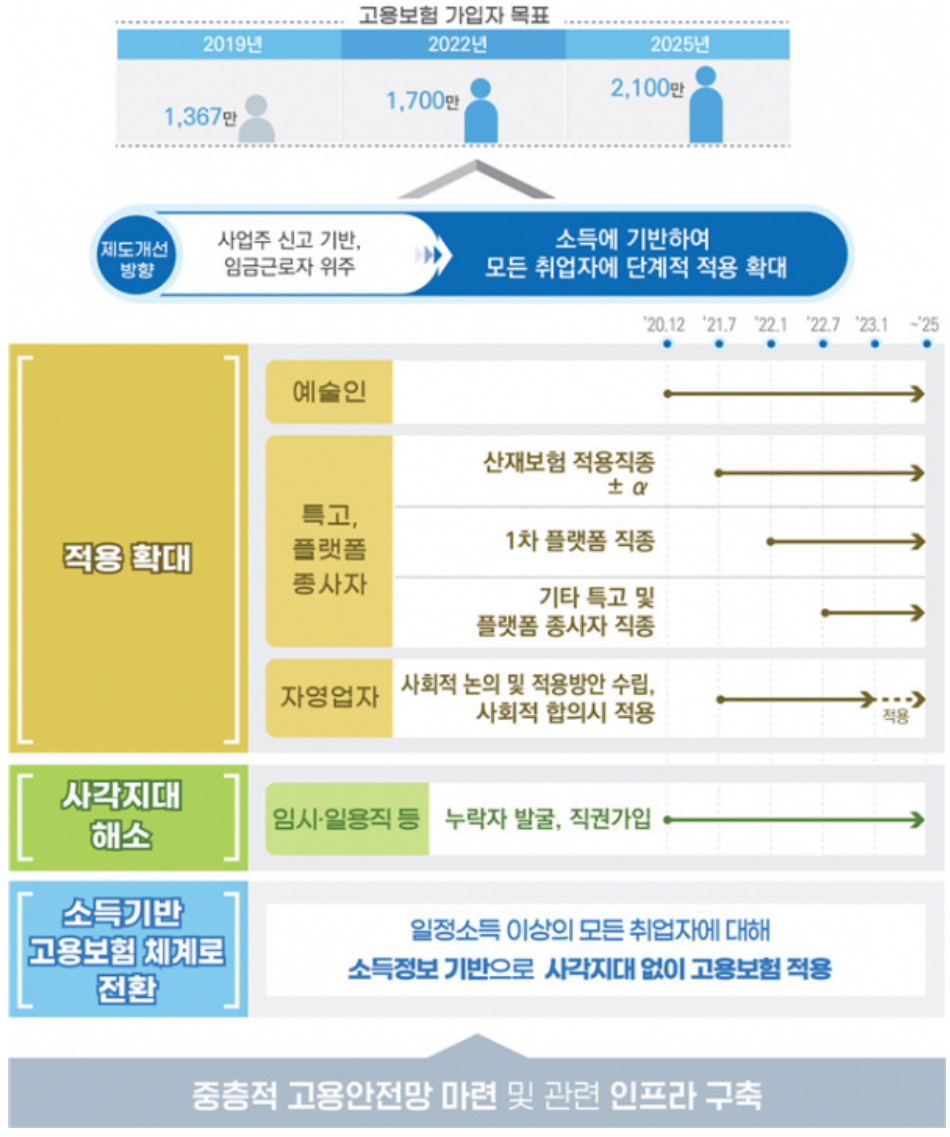

출처: 고용노동부(2020.12.23.). 전국민 고용보험 로드맵

\section{다. 대상별 고용보험 확대 계획}

고용보험 적용 확대 로드맵은 2020년 12월부터 예술인 적용, 2021년 7월부터 특수 형태근로종사자 적용, 2022년부터 플랫폼종사자 적용, 2025년까지 자영업자 적용을 목 표로 한다. 


\section{1) 예술인(2020.12.10. )}

2020년 5월 고용보험법 개정으로 2020년 12월 10일부터 예술인 고용보험이 시행되 었다. 현재는 제도 도입 초기 단계로 적극적인 가입 확대를 독려하고 제도 안착을 위해 노력하고 있다.

〈표 2-6〉예술인 고용보험

\begin{tabular}{|c|c|}
\hline 구분 & 내용 \\
\hline 적용대상 & $\begin{array}{l}\text { - 국내 예술인(17.8만명) 중 ‘지난 1년 간 예술활동 관련 계약체결 경험’이 있는 사람은 7.5만 } \\
\text { 명(42\%) }\end{array}$ \\
\hline 추진방안 & $\begin{array}{l}\text { - (겸업자 적용 확대) 예술인은 겸업 비중이 높으므로(43\%, '18년 기준), 당사자 신청 시 같은 } \\
\quad \text { 기간 동안의 계약서 상 소득을 합산하여 적용 } \\
\text { - (공공부문 책임 강화) 공공부문 발주의 경우 발주자 또는 원수급인에게 예술인 피보험자격 } \\
\quad \text { 신고 의무 부과 }\end{array}$ \\
\hline 지원방안 & $\begin{array}{l}\text { - (서면계약 관행 정착) 고용부·문체부-예술인재단 협업, 문화예술용역 가이드라인 마련 및 현 } \\
\text { 장점검 실시 } \\
\text { * 인터넷·모바일로 계약서를 쉽게 작성·체결하고 편리하게 교부·보존할 수 있도록 문화예술용 } \\
\text { 역 전자계약 플랫폼 마련 } \\
\text { - (전담 지원팀 설치) 근로복지공단 내 예술인 지원팀 및 소속기관(61개)에서 예술인 고용보험 } \\
\quad \text { 관련 상담 및 신고 접수 등 수행 }\end{array}$ \\
\hline
\end{tabular}

\section{2) 특수형태근로종사자·플랫폼 종사자(2021.7. )}

2020년 12월 9일 고용보험법·징수법 개정으로 특수형태근로종사자·플랫폼 종사자 적용을 위한 법적 기반을 마련하였다. 이에 따라 특고 및 플랫폼 종사자 직종별로 순차 적으로 적용하고, 플랫폼 관리기반을 구축할 계획이다.

〈표 2-7〉 특고· 플랫폼 종사자 확대 계획

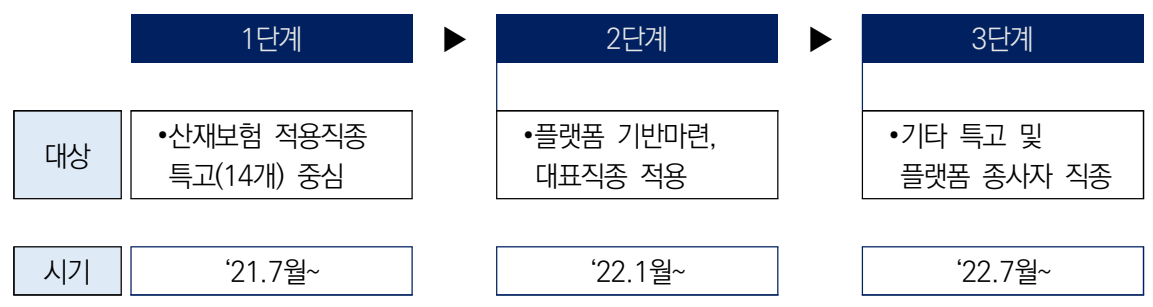

적용대상은 올해부터 산재보험 적용직종 중심으로 적용하되, 우선순위는 (1) 보호필요 성, (2) 관리가능성, (3) 사회적 영향력에 따라 결정할 예정이다. 산재보험 적용직종인 보 험설계사, 학습지교사 등이 우선 적용 대상이다. 
[그림 2-8] 산재보험 적용 직종(특고) 유형 분류

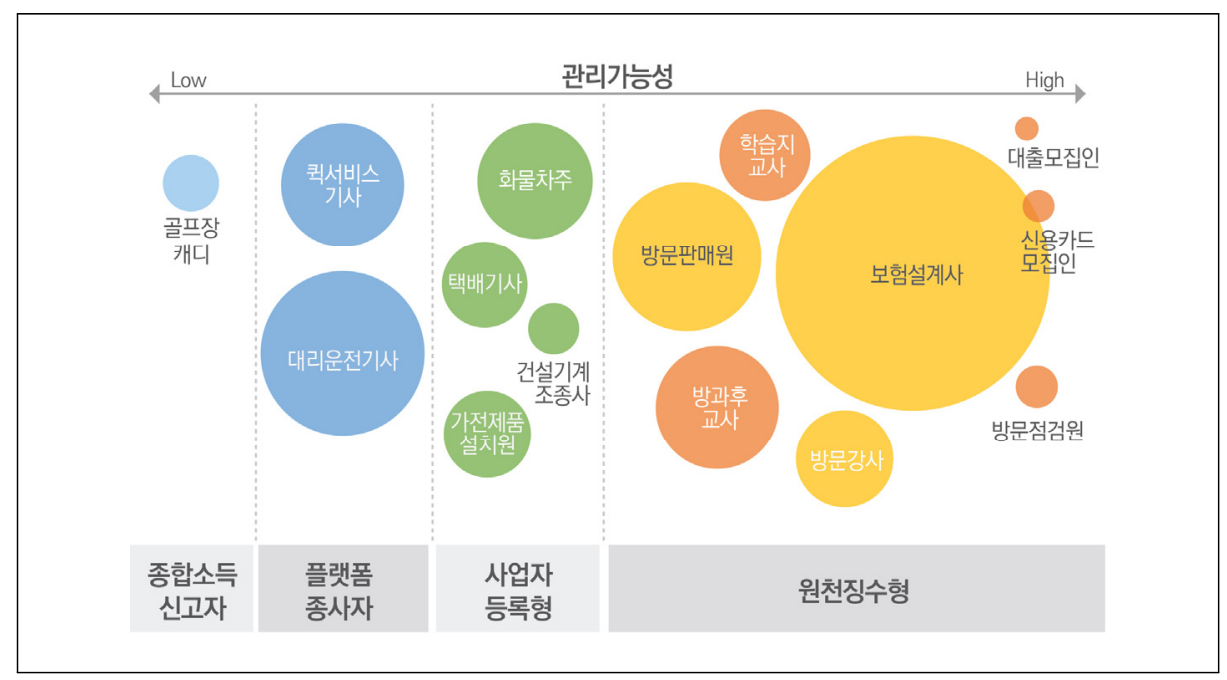

출처: 고용노동부(2020.12.23.). 전국민 고용보험 로드맵

\section{3) 기타 특고 및 플랫폼 직종 ('22.7 )}

3 단계 확대 대상은 1 2단계 적용대상에 포함되지 않은 플랫폼 종사자 및 기타 특고 직종이 해당된다. 추가 적용할 수 있는 특고 및 플랫폼 직종에 대한 실태조사, 노·사단체 의견수렴, 소득정보 활용 가능성 검토 등을 통해 적용대상을 결정할 예정이다.

기타 특고 직종은 실태조사와 정부 지원제도 수혜자 조사 등을 통해 추가 직종 현황을 파악하고 적용대상을 선정한다. 이 때 주요 고려사항은 사업주 특정이 용이하고, 종사자 등록시스템 등을 통해 관리가능성이 비교적 높으며, 노동시장 지위가 취약한 직종을 선 별하는 것이다. 고용노동부에서 그동안 특고 실태조사 자료에서 확인된 기타 직종은 (1) (운송·운수서비스) 영업용 구난차 기사, 학원차 기사, (2) (판매) 의류판매 중간관리자, 상 조회사 영업사원, (3) (전문서비스) 헤어디자이너, 스포츠강사, 행사도우미, 관광가이드, (4) (IT 분야 등) SW개발자, 그래픽디자이너 등이다. 추가직종은 실태조사 및 의견수렴 (2021년)을 거쳐 적용직종을 결정하고, 2022년 시행령 및 시행지침 개정을 추진 예정이다. 


\section{3. 코로나19 지원 고용대책}

2020년 코로나19의 영향으로 관광산업은 이례적인 위기를 경험하고 있다. 정부는 고 용위기를 우선 과제로 보고, 관광산업을 특별고용지원업종으로 지정하고, 고용대책을 추 진해 왔다.

〈표 2-8〉 코로나19 고용대책

\begin{tabular}{|c|c|c|}
\hline 구분 & 내용 & 세부 내용 \\
\hline \multirow{2}{*}{ 고용유지지원 } & $\begin{array}{l}\text { 고용유지기업 } \\
\text { 직접 지원 }\end{array}$ & $\begin{array}{l}\text { - 고용유지지원금 지원 대폭 강화: ‘19년 대비 신청 } 45 \\
\text { 배 증가(72천개소 138만명, '20.5월기준) } \\
\text { - 무급휴직 신속 지원, 임금감소분 지원 등 }\end{array}$ \\
\hline & 고용유지 인센티브 & $\begin{array}{l}\text { 특별고용지원업종 지정 } \\
\text { - 1차 : 여행업, 관광운송업, 관광숙박업 등 } \\
\text { - 2차 : 항공지상조업, 면세점업, 전시·국제회의업 등 }\end{array}$ \\
\hline \multirow{2}{*}{$\begin{array}{c}\text { 취업지원. } \\
\text { 일자리 기회 확대 }\end{array}$} & $\begin{array}{l}\text { 실업자 재취업- } \\
\text { 생계 지원 }\end{array}$ & $\begin{array}{l}\text { - 구직급여 대폭 확대(‘19년 144만명 } \rightarrow \text { ‘20년 186만명) } \\
\text { - 취업성공패키지(30만명), 청년구직활동금(10만명) 등 } \\
\text { 확대 지원 }\end{array}$ \\
\hline & 공공·청년일자리 & $\begin{array}{l}\text { - 비대면·디지털 공공일자리(10만명) } \\
\text { - 청년 디지털 일자리 및 일경험(10만명) } \\
\text { - 중소중견기업 채용장려금 등(5만명) }\end{array}$ \\
\hline \multirow{2}{*}{$\begin{array}{l}\text { 사각지대· } \\
\text { 취약계층 } \\
\text { 생계 지원 }\end{array}$} & 지역고용대응 등 특별사업 & $\begin{array}{l}\text { - 무급휴직자, 특고·프리랜서 대상 월50만원 } \times 2 \text { 개월 } \\
\text { - } 17 \text { 개 광역자치단체별 신청접수·지급 }\end{array}$ \\
\hline & $\begin{array}{c}\text { 코로나19 긴급고용 } \\
\text { 안정지원금 }\end{array}$ & $\begin{array}{l}\text { - 영세 자영업자, 특고·프리랜서 등 대상 월50만원 } \times 3 \text { 개 } \\
\text { 월(114만명) } \\
\text { - 고용센터 등 중앙정부 전달체계 활용 }\end{array}$ \\
\hline
\end{tabular}

자료: 이병희(2020). 전국민 고용보험과 한국형 실업부조, 사람중심 경제 전국민 고용안전망 구축 방안 토론회(2020.7.8.) 발표자료

\section{가. 특별고용지원업종 지정}

특별고용지원업종 지정은 경제 환경의 급격한 변화 등으로 고용사정이 급격히 악화되 거나, 악화될 우려가 있는 업종을 특별고용지원업종으로 지정하여 사업주·근로자에 대 한 종합적 지원을 제공하는 제도이다. 특별고용지원 업종으로 지정되면 사업주와 노동자 가 모두 지원을 받게 된다. 
〈표 2-9〉 코로나19 고용대책 - 특별고용지원업종

\begin{tabular}{|c|c|}
\hline 사업주 지원 & 근로자 및 구직자 생활안정 지원 \\
\hline $\begin{array}{l}\text { - 고용유지지원금의 지원수준이 우선지원대상기 } \\
\text { 업의 경우 휴업 휴직수당의 최대 } 66 \% \text { 에서 } \\
90 \% \text { 까지로, } 1 \text { 일 한도는 } 6 \text { 만 6천원에서 } 7 \text { 만원 } \\
\text { 으로 높아짐 } \\
\text { - 무급휴직 지원금 지원요건 완화 } \\
\text { - 고용보험 및 산업재해보상보험 보험료, 장애인 } \\
\text { 의무고용 부담금의 납부기한이 } 6 \text { 개월간 연장되 } \\
\text { 고, 체납처분 집행이 유예 } \\
\text { - 건강보험의 경우 지정기간 동안 연체료 부과 } \\
\text { 없고, 체납처분 집행도 유예 } \\
\text { - 사업주에 대한직업훈련훈련비 지원단가가 상향, } \\
\text { 지원한도도 납부보험료의 } 240 \% \text { 에서 } 300 \% \text { 로 } \\
\text { 상향(우선 지원 대상기업 기준) }\end{array}$ & $\begin{array}{l}\text { - 근로자 생환안정자금 융자 한도 환대, 소득요건 완화 } \\
\text { - 임금체불 생계비 융자 한도는 1천만원에서 2천만원으 } \\
\text { 로, 자녀학자금 융자 한도는 연 } 5 \text { 백만원에서 } 7 \text { 백만원 } \\
\text { 으로 상향조정, 상환기간은 최대 } 5 \text { 년에서 최대 } 8 \text { 년으 } \\
\text { 로 연장 } \\
\text { - 임금감소 소액생계비 융자를 위한 소득요건 월 } 181 \text { 만 } \\
\text { 원에서 월 } 222 \text { 만원으로, 다른 생계비는 월 } 259 \text { 만원 } \\
\text { 에서 월317만원으로 완화 } \\
\text { - 직업훈련 생계비 융자 한도가 } 1 \text { 천만원에서 } 2 \text { 천만원으로 } \\
\text { 확대, 체당금 조력대상 사업장은 상시 } 10 \text { 명 미만에서 } \\
\text { 30명 미만 사업장으로 환대 } \\
\text { - 국민내일배움카드의 자부담률이 최대 } 55 \% \text { 에서 } 20 \% \text { 로 } \\
\text { 완화, 훈련비 한도도 } 5 \text { 년간 } 300 \text { 만원에서 } 400 \text { 만원으로 } \\
\text { 상승 } \\
\text { - 지정 업종 기업에서 지원기간 중 이직한 후 실업상태에 } \\
\text { 있는 근로자는 취업성공패키지 에 참여할 때 소득요건 } \\
\text { 면제 }\end{array}$ \\
\hline
\end{tabular}

\section{나. 경제사회노동위원회 관광산업위원회 발족}

정부는 대통령 직속 경제사회노동위원회에 관광산업위원회를 발족(2020.6.19) 하여, 코로나19 장기화로 고용위기 직격탄을 맞은 호텔·면세점·여행사 노동자의 고용안정 방 안과 관광·서비스산업 경쟁력 확보 방안을 모색하고 있다.

\section{《관광산업위원회 운영 개요》}

$\square$ 설치목적 : 신종 코로나바이러스 감염증 사태 장기화로 고용위기 직격탄을 맞은 호텔·면세점·여행사 노동자 의 고용안정 방안과 관광산업 경쟁력 확보 방안 모색

운영기간 : 2020.06.19. 2021.06.18.

주요 논의사항

- 노동자 고용 및 노동조건, 노사정 상생협력을 통한 관광산업 발전 방안

- 노동자 직업능력개발훈련 등에 관한 사항

자료: http://mww.eslc.go.kr/bbs/data/list.do?menu_idx=2320

관광산업에 대해 특별고용지원업종 지정, 고용유지지원금 지원 등을 통해 관광산업 위기 극복을 지원하고 있으나, 관광산업 경기침체와 고용불안은 여전히 심각한 상황이 다. 위원회는 피해가 심각한 호텔·면세점·여행· $\mathrm{MICE}$ 업종을 중심으로 고용실태를 파악 
하고, 비정규직 협력업체 노동자 보호, 관광산업 생태계 유지를 위한 숙련인력 지원 방 안 등을 논의하였다. 위원회는 2020년 8월, 관광산업 생태계 유지와 고용안정을 위한 긴급 노사정 합의문을 발표하였다. 합의문의 내용은 (1) 관광산업 종사자 고용안정 방안 (2) 관광산업 생태계 유지와 이후 빠른 복원을 위한 관광산업 생태계 활성화 방안 (3) 위기 극복을 위한 노사정의 노력으로 구성되었다.

〈표 2-10〉 코로나19 노사정 합의안

\begin{tabular}{|c|c|}
\hline 구분 & 세부 내용 \\
\hline $\begin{array}{l}\text { 관광산업 } \\
\text { 종사자 } \\
\text { 고용안정 } \\
\text { 방안 }\end{array}$ & $\begin{array}{l}\text { 1-1. 『코로나19 극복을 위한 노사정 협약에서 특별고용지원업종에 대한 고용유지지원금 지급 } \\
\text { 기간을 } 60 \text { 일 연장하기로 합의한 바, 노사는 고용유지지원금을 추가로 지원받는 사업장의 } \\
\text { 경우 지원금 종료일 기준 최소 } 2 \text { 개월 이내에는 감원하지 않기 위해 노력하기로 합의한다. } \\
\text { 1-2. 노사정은 비정규직을 포함한 관광산업 노동자의 고용구조 파악을 위한 실태조사에 노·사. } \\
\text { 정·전문가가 참여하는 방안을 공동으로 마련한다. } \\
\text { 1-3. 노사는 계약직 노동자와 협력업체 노동자의 고용보호를 위해 노력하고, 정부는 고용유지지 } \\
\text { 원제도 사각지대에 있는 고용 취약계층 보호방안을 적극적으로 모색한다. } \\
\text { 1-4. 노사정은 현재 직업능력개발 훈련과정 수강생 중 실업자와 고용보험 임의가입 자영업자에 } \\
\text { 게 지급하는 훈련장려금을 무급휴직자까지 확대 지급하기로 합의한다. } \\
\text { 1-5. 노사정은 유원시설업을 비롯한 관광업종 전반의 경영상황에 대한 실태조사를 실시하기로 } \\
\text { 합의한다. 이를 토대로 노사는 유원시설업 등 관광어ㅂㅗㅗㅇㅇㅢ 특별고용지원업종 추가 지정을 } \\
\text { 정부에 건의한다. }\end{array}$ \\
\hline $\begin{array}{c}\text { 관광산업 } \\
\text { 생태계 } \\
\text { 활성화 방안 }\end{array}$ & $\begin{array}{l}\text { 2-1. 노사정은 일반 추경예산을 통한 관광진흥개발기금 확충 필요성에 공감하며, 재원 확충을 } \\
\text { 통해 보다 적극적인 내수활성화 정책을 추진하기로 합의한다. } \\
\text { 2-2. 노사정은 시민과 관광객의 안전을 최우선 목표로 관광산업에 특화된 철저한 코로나19 안전 } \\
\text { 프로토콜을 구축·시행하고, 정부 및 지방자치단체는 권역 내 해당기업에 방역인력과 자원을 } \\
\text { 적극 지원하도록 노력한다. } \\
\text { 2-3. 노사정은 정부와 지방자치단체가 지역 내 관광산업 육성을 위해 관내 경영계와 공동으로 } \\
\text { 다양한 관광상품을 개발하고, 할인쿠폰 발행 등의 사업를 통해 지역관광 수요를 창출하도 } \\
\text { 록 노력한다. } \\
\text { 2-4 정부는 코로나19 등으로 매출이 급감한 관광산업 위기를 고려해 융자제도 개선 연구를 추진 } \\
\text { 한다. 노사는 한시적 부가가치세 면제 및 환급기간 연장, 면세점 특허수수료 한시적 인하 } \\
\text { 등 다양한 금융 및 세제지원을 적극 건의한다. } \\
\text { 2-5. 노사정은 중소기업 자영업자 대상 경영회복, 국내 관광상품 개발, 관련제도 설명 등 경영지 } \\
\text { 원 컨설팅사업을 실시하기로 합의한다. }\end{array}$ \\
\hline $\begin{array}{c}\text { 위기 극복을 } \\
\text { 위한 } \\
\text { 노사정의 } \\
\text { 노력 }\end{array}$ & $\begin{array}{l}\text { 3-1. 경영계는 고용조정이 최후의 수단임을 인식하고, 코로나 위기 이후 산업생태계가 빨리 회복 } \\
\text { 될 수 있도록 지금까지 함께해 온 노동자들의 고용을 유지하는 데 최대한 노력한다. } \\
\text { 3-2. 노동계는 코로나19에 따른 매출 급감 등 경영위기 극복을 위해 적극 협력하며 최대한 고용 } \\
\text { 이 유지될 수 있도록 노력한다. } \\
\text { 3-3. 노동계와 경영계는 코로나19 위기 극복을 위한 상시적 대화창구를 구성 운영한다. } \\
\text { 3-4. 경영계는 관광산업 위기가 지속되는 동안 사업장에서 노동관계 법령을 준수하며, 정부는 } \\
\quad \text { 지원 및 지도·감독을 강화한다. }\end{array}$ \\
\hline
\end{tabular}

자료: 경제사회노동위원회 관광산업위원회 홈페이지 


\section{제3절 종합분석}

고용안전망은 노동시장에서 실업의 위험에 대응하기 위한 체계를 말하며, 고용보험이 1 차적 고용안전망의 중심을 이루는 제도이다. 이 연구에서는 관광산업의 고용안전망을 '실직, 산업재해, 질병 등 사회적 고용 상 위험으로부터 관광분야 종사자들을 안전하게 보호하는 법제도적 체계'로 정의하고, 특히 고용을 통하여 개인과 가정, 더 나아가 사회 의 안정을 유지하고 다시 일할 수 있는 기회와 일자리 이동을 위해 고용보험 제도를 통 해 지원하는 사회시스템으로 보았다.

고용안전망 사각지대의 유형은 업종에 따라 다양하게 나타난다. 현실적인 이유로 고 용보험에 가입해야 하는데 가입을 하지 못했던 사람들, 근로자가 아니기 때문에 고용보 험에 가입하지 못했던 사람들, 가입대상은 됐지만 적용 제외 신청을 하거나 여러 가지 탈법적인 형태로 빠져 나갔던 사람 등을 포함하고 있다. 이 때문에 고용안전망에 대한 접근은 사각지대를 파악하고, 사각지대 해소를 위한 제도적 방안을 확대하는 것이 중요 하다.

정부는 2017년부터 '일자리 강화' 정책을 목표로, 포괄적인 사회보험을 구축하여 기 존 사각지대 해소 방안을 발표해왔다. 이러한 연장선에서 2020년 발표한 '전국민 고용 보험제도' 도입은 우리나라 고용안전망 강화 정책의 중요한 변곡점으로 볼 수 있다.

전국민 고용보험 도입은 기존 고용안전망의 사각지대에 놓여있는 사람들을 점진적으 로 포괄하는 고용보험의 단계적 확대와 국민취업지원제도를 시행하는 고용안전망 강화 라고 볼 수 있다. 미가입자를 가입 유도 하는 우선적인 정책과 사각지대 해소, 궁극적으 로 일하는 사람 전부에게 고용보험 적용을 확대한다는 것이다.

정부는 전국민 고용보험 로드맵을 제시하고, 2020년 12월부터 예술인에 대한 고용보 험 적용을 시작으로, 근로자와 자영업자의 중간적인 지위에 있는 특수형태 근로종사자에 대한 고용보험 적용, 마지막 단계는 사회적 대화를 통해 자영업자의 고용보험 적용으로 
확대하는 방향을 제시하였다. 또한 개별 소득기반 고용보험 체계로의 전환을 통하여 사 업장에 소속되어 있지 않더라도 고용보험을 적용할 수 있도록 하는 것이 전국민 고용보 험 로드맵의 내용이다. 특수형태 근로자와 자영업자는 사업자 신분을 갖고 있는 경우가 많기 때문에 사업장 단위로 적용하는 고용보험과는 차이가 있어 직종별 특성과 적용 여 부를 검토하는 단계이다.

동시에 일자리 이력이 없고, 보험 가입이 이력이 없는 사람들, 특히 청년층 대상 실업 부조제도인 ‘국민취업지원제도' 도입을 발표했다. 과거에도 취업성공패키지 등의 사업이 추진되었으나 근거 법을 만들어 제도화하겠다는 것이다. 코로나19 위기 이후 실업이 문 제가 되고, 일자리 문제가 심각해지면서 제도화의 필요성이 강조되고 있다.

고용안전망 정책은 정부가 추진하는 전국민 고용보험 로드맵의 정책 흐름에 대응하여 관광산업 영역에서 요구되는 정책 과제를 발굴하고, 지원 방안을 모색하는 것이 필요하 다. 특히, 산업적 관점에서는 결국은 고용보험 적용 부분 확대에 집중할 필요가 있다. 고용보험 적용 범위 확대는 2022년 7월까지 노무제공자를 포섭할 수 있는 직종이 있는 지 여부를 검토하여 추가하고, 세부적인 제도화 방안을 논의할 계획이다. 핵심 사항은 어떤 특정한 직종이나 업종에서 근로자도 아니고 완전한 자영업자도 아닌 종속적 자영 업자로서 필요성이 있고 고용보험 가입이 필요하며, 원칙적인 적용대상으로 노무 제공자 가 될 필요가 있다는 부분을 강조할 필요가 있다.

정부는 2020년 코로나19의 영향으로 고용상의 피해를 최소화하기 위하여 관광산업 의 주요 업종을 특별고용지원업종으로 지정하고 지원하고 있다. 관광산업에서 코로나19 와 같은 위기 상황은 향후 중장기적으로 언제든 반복될 수 있는 위기이다. 코로나19를 관광산업의 위기대응 체계를 구축하는 계기로 삼아 고용 안정성을 높이기 위한 제도적 방안을 모색해야 한다. 

관광산업 고용안전망 구축방안

제3장

고용안전망 관련 제도 및 사례 분석 



\section{제1절 우리나라 고용안전망 관련 제도 분석}

\section{1. 고용보험제도}

\section{가. 개요}

고용보험은 1995 년 7월에 상시근로자 30인 이상의 사업장(실업급여)에 도입되었다. 당시에 고용보험 적용대상은 고용안정사업과 직업능력개발사업의 경우에 상시근로자 70 인 이상의 사업장이었다. 1998년 10월부터 모든 고용보험사업은 상시근로자 1 인 이 상을 고용하는 사업장을 적용대상으로 하게 되었던 것이다(이승렬, 2007).

2004년에는 일용근로자, 60세 이후의 신규고용자, 시간제근로자의 적용확대, 국가와 지자체가 실시하는 공공근로종사자, 연근해 어선원, 일부 외국인근로자가 고용보험 적용 대상에 편입되었다. 2005년 12월의 고용보험법 시행령 개정으로 가입을 희망하는 영세 자영업자 5 인 미만의 사업주)가 2006년부터 직업능력개발사업에 해당 고용보험료를 납 부하고 참여할 수 있게 되었다. 따라서 사업자등록증을 가진 특수형태근로종사자의 경우 도 영세자영업자의 범주에 해당하므로 고용보험 가입이 가능하다(이승렬, 2007).

고용보험제도는 실업의 위험에서 임금근로자를 보호하는 사회안전망의 기능을 담당 하며, 적용 범위가 임금근로자의 범위를 벗어나 중소기업 사업주나 영세자영업자 등 일 하는 사람 전반을 보호대상으로 포함하는 방향으로 논의가 확장되고 있다.

\section{나. 고용보험 사업의 내용2)}

고용보험 관련 사업은 크게 고용안정사업, 직업능력개발사업, 실업급여로 구분되며 (고용노동부, 2018), 육아휴직 등 여성근로자의 고용안정 지원사업을 포함하고 있다.

2) 고용노동부(2018).「2018 고용보험백서」의 내용을 토대로 작성함 
첫째, 고용안정사업은 근로시간 단축, 교대제 전환 등을 통해 일자리를 창출하는 고용 창출사업, 경기의 변동이나 산업구조의 변화과정에서 기업의 고용 조정이 실업을 최소화 하면서 원활하게 이루어질 수 있도록 지원함으로써 근로자의 고용안정을 도모하는 고용 조정지원사업과 고령자·여성 등 노동시장 취약계층에 대한 고용촉진지원사업, 고용촉진 시설지원 및 건설근로자고용안정사업 등이 해당된다(고용노동부, 2018).

둘째, 직업능력개발사업은 사업주가 소속 근로자를 대상으로 실시하는 직업능력 개발 훈련을 제공할 경우 지원하는 사업주 훈련 지원, 근로자가 자기 주도적으로 훈련에 참여 할 경우 지원하는 근로자 개인 주도 훈련 지원, 실업자들이 취업 역량 강화를 목적으로 훈련에 참여할 경우 지원하는 실업자 훈련 지원 등으로 구성된다. 국가직무능력표준 (NCS) 개발과 이에 기초한 직업능력개발 시스템 개편, 기업현장에서 인력양성이 이루어 지는 일학습병행제 등을 통해 적극적 고용정책을 추진하고 있다(고용노동부, 2018).

셋째, 실업급여는 구직급여와 취업촉진수당으로 구성되어 있으며 기본적으로 소정의 급여조건을 만족하는 실직근로자에게 일정기간 구직급여를 지급하여 실직자의 생활안정 은 물론 실직자의 조기재취업을 유도하기 위한 것이다. 우리나라의 실업급여는 전통적인 실직기간 동안의 기본급여 뿐만 아니라 실직자의 직업훈련 수강을 용이하게 하기 위하 여 직업훈련기간 동안 기본급여를 연장해 주는 등 직업훈련수강을 유인하기 위한 인센 티브 제도를 두고 있고 조기 재취업시에는 조기재취업수당을 지급함으로써 실직자가 기 본급여에 안주하여 재취업활동을 게을리 하지 않도록 취업지원 제도로서의 기능도 수행 하고 있다(고용노동부, 2018).

넷째, 여성근로자의 고용안정을 위하여 육아휴직 급여 및 출산전후휴가 급여 등을 지 원함으로서 모성보호의 사회적 책임을 뒷받침하고 있다. 출산전후휴가 급여 및 육아휴직 급여는 임신·출산으로 인한 여성근로자의 노동시장 이탈을 방지하고, 사업주의 여성고 용 기피요인 해소 및 육아휴직의 실질적 활용을 통한 일-가정 양립 지원을 확대하기 위 한 정책이다. 또한 육아휴직 급여 외에도 육아기 근로시간 단축 급여를 통해 아동을 위 해 필요한 시간을 확보하면서도 고용을 유지해 나갈 수 있도록 하는 정책도 추진 중이다 (고용노동부, 2018).

고용보험 제도는 실업이나 고용 조정 등으로 인한 노동자 보호 등 고용안정 뿐 아니 라, 직업능력 개발을 통하여 노동생산성을 향상시키고 근로자의 임금수준 향상을 도모함 은 물론 기업의 경쟁력을 강화하는 역할을 수행한다(고용노동부, 2018). 


\section{다. 적용 범위 및 대상}

고용보험은 적용대상에 따라 일반적인 당연적용사업과 임의가입사업으로 구분한다. 근로자를 고용하는 모든 사업 또는 사업장의 사업주는 원칙적으로 고용보험의 당연가입 대상이다. 다만, 사업장의 규모 등을 고려하여 일부 사업장은 고용보험 당연가입대상에 서 제외하고 있다. 사업의 규모 등으로 고용보험법의 당연가입 대상사업이 아닌 사업의 경우 임의가입으로 근로복지공단의 승인을 얻어 고용보험 가입이 가능하다.

\section{「고용보험법 시행령」제2조}

《적용 제외 대상》

- 농업, 임업 및 어업 중 법인이 아닌 자가 상시 4명 이하의 근로자를 사용하는 사업

- 가구 내 고용활동 및 달리 분류되지 아니한 자가 소비 생산 활동

- 건설업자 등이 아닌 자가 시공하는 총공사금액 2 천만원 미만인 공사, 연면적 100 제곱미터 이하인 건축물의 건축 또는 연면적이 200제곱미터 이하인 건축물의 대수선에 관한 공사

1995년 7월 1일 고용보험제도 도입 시 당연적용 사업장 규모가 30인 이상이었기 때 문에 자영업자, 가족종사자를 제외하고 이들 사업장에 속한 임금근로자는 고용보험의 적 용대상에 포함되었다. 그러나 고용형태의 특성상 고용보험을 적용하기에 어려운 일부 근 로자는 적용 제외하도록 규정하고 있다. 예컨대 60세 이후에 새로이 고용된 자, 시간제 근로자, 일용근로자, 1 월간 소정근로시간이 60시간(1주간 소정근로시간 15시간) 미만인 자는 적용에서 제외하였다.

2004년 1월 1일부터는 일용근로자, 60세 이후에 새로이 고용되는 자(64세까지 적용) 에 대하여도 고용보험 적용을 확대 하였고, 시간제근로자의 적용범위도 대폭 확대되었으 며, 2006년 1월 1일부터는 65세 이상인 자의 경우에도 실업급여 대상은 제외되나, 고용 안정·직업능력개발사업을 적용받도록 하였다.

2013년 6월 4일부터는 65세 이상자의 노동시장 재진입이 증가하고 실업급여 지급을 통한 재취업 지원의 필요성이 커지면서 적용제외 대상을 기존 ' 65 세 이상인 자’에서 '65 세 이후에 새로이 고용되거나 자영업을 개시한 자로 고용보험 적용대상을 확대하였다. 외국인의 경우에는 원칙적으로 고용보험을 적용하지 않으나 국내거주 자격(F-2) 및 영 주의 자격(F-5, F-6(결혼이민))을 갖고 있는 경우에는 당연 적용대상으로 하고, 기타 국 내취업활동이 가능한 체류자격을 가진 경우에는 가입을 희망하는 경우 가입할 수 있도 
록 임의적용하고 있다(고용노동부, 2018).

고용보험은 적용 사업에 고용된 모든 근로자에게 적용되나, 다음에 해당하는 자에게 는 적용을 제외하고 있다.

\section{「고용보험법」제 10 조}

《적용 제외》

- 65세 이후 고용되거나 자영업을 개시한 자: 실업급여(법 제4장), 육아휴직급여 등(법 제5장) 적용 제외(고용 안정·직업능력개발사업은 적용함에 따라 고용보험 피보험자격 취득 대상임)

* 다만, 65 세 전부터 피보험자격을 유지하던 사람이 65 세 이후에 계속하여 고용된 경우는 실업급여 등 고용보험 전 사업 적용(19.1.15시행)

- 1개월간 소정근로시간이 60시간 미만인 자(1주간의 소정근로시간이 15시간 미만인자 포함)

* 다만, 3 개월 이상 계속하여 근로를 제공하는 자와 1 개월 미만동안 고용되는 일용근로자는 적용 대상임

- 「국가공무원법」과「지방공무원법」에 따른 공무원

* 다만, 별정직·임기제공무원은 본인의 의사에 따라 최초 임용된 날부터 3개월 이내 임의가입 가능(실업급 여만 적용)

* 고용보험 가입을 신청하려는 경우 최초 임용된 날부터 3개월 이내 별정직.임기제공무원 고용보험 가입신 청서와 재직증명서를 근로복지공단에 제출해야 함(3개월 이내 신청하지 않을 경우 가입 불가)

- 「사립학교교직원 연금법」의 적용을 받는 자

- 외국인근로자

* 외국인근로자의 경우 고용보험 적용제외 대상이나, 일부 체류자격의 경우 당연, 임의, 상호주의로 구분 적용

- 「별정우체국법」에 따른 별정우체국 직원

고용보험은 확대된 의미에서 사회보험의 역할 수행을 위해 사회안전망이 취약한 대상 을 고용보험에 임의 적용하여 보호하고 있다. 임의가입 대상으로서는 1 인 자영업자 또는 50인 미만의 근로자를 고용하고 있는 자영업자가 해당된다(고용노동부, 2018).

고용안전망 확충은 전반적으로 필요성에 공감하고 있으나, 고용보험 적용 대상 확대 와 관련한 구체적인 정책 수단은 다양한 의견이 논의되고 있다. 고용보험 가입대상 확대 는 임금근로자를 기초로 설계된 고용보험의 한계를 보완하기 위한 것으로 법제도적 사 각지대를 해소하기 위한 것이다. 이 때문에 현재의 고용보험제도 보완을 위해서는 사각 지대에 대한 규명과 특성 파악이 선결될 필요가 있으며, 고용보험제도 적용을 위하여 직종별 특성을 고려한 보완 방안 마련이 요구된다. 


\section{2. 고용위기지역 및 산업(업종) 지원 제도}

\section{가. 추진배경}

국내외 경제사정의 변화 등으로 고용사정이 급격히 악화된 지역의 경우 기존의 파편 적인 지원만으로는 효과적으로 위기를 극복하기 어렵다. 특히 지역별 산업 집적으로 인 해 특정 산업의 위기 또는 불황이 지역수준의 경제 불황으로 연결되는 경우가 많아 지역 과 산업의 여건을 고려한 특화된 지원이 필요하게 되었다. 이러한 이유로 고용노동부는 2009년부터 고용촉진특별구역 지정제도를 신설하여, 고용촉진특별구역으로 지정된 지 역에 대하여 고용창출, 고용유지, 전직지원 등을 집중적으로 지원하였다.

고용노동부는 고용위기가 특정 기업·지역이 아닌 산업 전반에서 구조조정 등으로 고 용상황이 악화되거나 악화될 우려가 있는 업종에 대한 종합적 지원 필요성이 대두되면 서, 특별고용지원업종 제도를 신설하여 시행 중에 있다(2015.12.15 고시 제정).

\section{나. 조선업 고용지원대책}

조선산업은 2000년대 이후 수출 증가와 일자리 창출 기여하는 주력 산업으로 위상을 강화해 왔다. 2008년 금융위기 이후 세계 조선산업이 침체기에 접어들면서 이어진 조선 업의 불황은 대량 고용조정 등 노동시장 불안과 지역 연관산업 등 지역경제에 어려움을 초래하였다. 실제로 조선업은 고용보험 피보험자 기준으로 2016년 말 약 15만 6천명에 서 2017년 말 약 11만 4천명으로 약 4만 2천명이 감소하는 등 심각한 고용충격을 겪었 다(고용노동부, 2018). 이러한 배경에서 정부는 조선업을 최초로 특별고용지원업종으로 지정하고 '고용지원 및 지역경제 대책’을 발표하였다.

[그림 3-1] 조선업 특별고용지원대책 구조

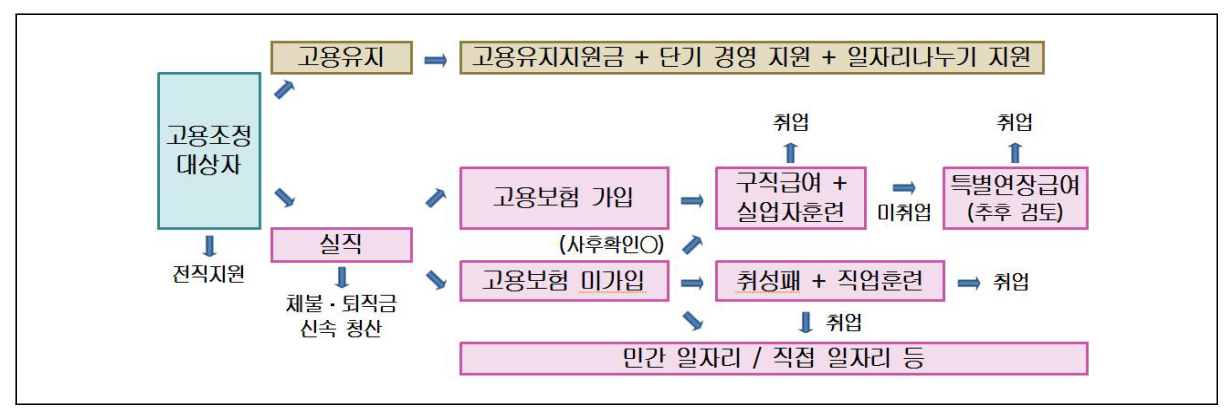


대규모 실업에 선제적으로 대응하고 지역경제 회복과 안정화를 위한 고용지원을 위하 여 특별고용지원업종으로 지정하고 추가 지원을 강화하였다.

〈표 3-1〉 특별고용지원업종 지정에 따른 추가지원 내용

\begin{tabular}{|c|c|c|c|}
\hline \multicolumn{2}{|r|}{ 구분 } & 기준 & 지정 시 \\
\hline \multirow{3}{*}{$\begin{array}{l}\text { 고용유지 } \\
\text { 지원금 }\end{array}$} & 지원수준 & $\begin{array}{l}\text { 우선지원대상기업 } 2 / 3 \\
\text { 대규모기업 } 1 / 2\end{array}$ & $\begin{array}{l}\text { 우선지원대상기업 3/4 } \\
\text { 대규모기업 } 2 / 3\end{array}$ \\
\hline & 지원한도 & 1일 5만원 & 1일 7만원(대규모기업 6만원) \\
\hline & 지원요건 & $\begin{array}{l}\text { 고용조정·신규채용 } \\
\text { 원칙적으로 금지 }\end{array}$ & $\begin{array}{l}\text { 고용조정·신규채용 } \\
\text { 부분적으로 가능 }\end{array}$ \\
\hline \multirow[b]{2}{*}{$\begin{array}{l}\text { 무급휴직 } \\
\text { 근로자 } \\
\text { 지원금* }\end{array}$} & 지원한도 & 1일 5만원 & 1일 6만원 \\
\hline & 지원요건 & $\begin{array}{l}\text { (1) 무급휴직 실시(90일) } \\
\text { (2) 무급휴직 전 1년 이내 } \\
\text { 유급휴업·훈련(3개월) }\end{array}$ & $\begin{array}{l}\text { (1) 무급휴직 실시(30일) } \\
\text { (2) 무급휴직 전 1년 이내 } \\
\text { 유급휴업·훈련(1개월) }\end{array}$ \\
\hline \multirow{3}{*}{ 훈련 } & $\begin{array}{l}\text { 사업주 훈련지원 } \\
\text { (지원한도 상향) }\end{array}$ & $\begin{array}{l}\text { 납부보험료의 } 100 \% \\
\text { (우선지원대상기업은 240\%) }\end{array}$ & $\begin{array}{l}\text { 납부보험료의 } 130 \% \\
\text { (우선지원대상기업은 300\%) }\end{array}$ \\
\hline & $\begin{array}{c}\text { 전직훈련 } \\
\text { (지원수준 이상) }\end{array}$ & $\begin{array}{l}\text { - 우선지원대상기업 } 120 \% \\
\text { - 1000인 미만 } 80 \% \\
\text { - 1000인 이상 } 50 \%\end{array}$ & $\begin{array}{l}\text { - 우선지원대상기업 } 150 \% \\
\text { - 1000인 미만 } 120 \% \\
\text { - 1000인 이상 } 90 \%\end{array}$ \\
\hline & 계좌발급 & 자부담 0 80\% & 자부담률 인하 \\
\hline \multicolumn{2}{|c|}{$\begin{array}{c}\text { 고용·산재보험료 및 } \\
\text { 장애인 의무고용 부담금 }\end{array}$} & 납부유예 $\times$ & 납부유예 $\bigcirc$ \\
\hline \multicolumn{2}{|c|}{$\begin{array}{l}\text { 고용보험 지연신고에 } \\
\text { 따른 사업주 과태료 }\end{array}$} & $\begin{array}{l}\text { 부과 } \\
\text { (1인당 3만원) }\end{array}$ & $\begin{array}{l}\text { 면제 } \\
\text { (자진신고 기간 중) }\end{array}$ \\
\hline \multicolumn{2}{|c|}{ 특별연장급여 } & - & $\begin{array}{l}\text { 60일 범위 내에서, 구직급여일액의 } \\
70 \% \rightarrow \text { 현재는 } 46,584 \text { 원 }\end{array}$ \\
\hline \multicolumn{2}{|c|}{ 취업성공패키지 || } & 중위소득 $100 \%$ 이하 & $\begin{array}{l}\text { 특별고용지원업종 실업자 } \\
\text { 소득요건 해제 }\end{array}$ \\
\hline \multicolumn{2}{|c|}{$\begin{array}{c}\text { 지역·산업 맞춤형 } \\
\text { 일자리 창출 지원사업 }\end{array}$} & 한도: 50억원 & 한도: 80억원 \\
\hline \multirow{2}{*}{$\begin{array}{l}\text { 체당금 } \\
\text { 운영 개선 }\end{array}$} & 지급요건 & 6 개월 이상 사업수행 & $\begin{array}{l}\text { 사업수행기간 합산 시 6개월 이상 } \\
\text { (중간의 중단기간 1년 이내) }\end{array}$ \\
\hline & 조력지원 & 10 인 미만 사업장 & 30 인 미만 사업장 \\
\hline \multicolumn{2}{|c|}{ 인프라(특화 전달체계) } & - & 조선업 희망센터 신설 \\
\hline
\end{tabular}

자료: 고용노동부(2018). 2018 고용보험백서, p.151 


\section{3. 예술인 고용보험제도3)}

\section{가. 법적 근거}

예술인은 수입이 불규칙하고 예술활동으로 소득이 발생하는 기간 이외에는 사실상 실 업상태에 놓여 있다. 예술인의 특성상 활동 준비기간이 길고, 이 기간에 생활안정자금이 필요하기 때문에 「고용보험법」에 예술인 고용보험 적용 특례 규정을 두어 실업급여를 받을 수 있도록 하였다. 예술인이 출산 또는 유산-사산 등으로 노무를 제공할 수 없을 때도 이 제도에 따라 출산전후 급여 등을 지급해 출산에 따른 경제적 부담을 경감할 수 있게 되었다. 예술인 고용보험은 「고용보험법」과「고용보험 및 산업재해보상보험의 보 험료징수 등에 관한 법률」이 개정됨에 따라 2020년 12월 10일부터 시행되고 있다.

\section{나. 주요 내용}

예술인 고용보험은 고용보험법령에서 정한 예술인 모두에게 당연 적용된다. 따라서 「고용보험법」과「보험료징수법」 등에서 정한 사업주는 고용보험 적용대상이 되는 문화 예술용역 관련 계약을 체결한 예술인에 대해 피보험자격 관련 신고를 하고 보험료 납부 등을 해야 한다(문화체육관광부, 2020).

[그림 3-2] 예술인 고용보험 적용대상

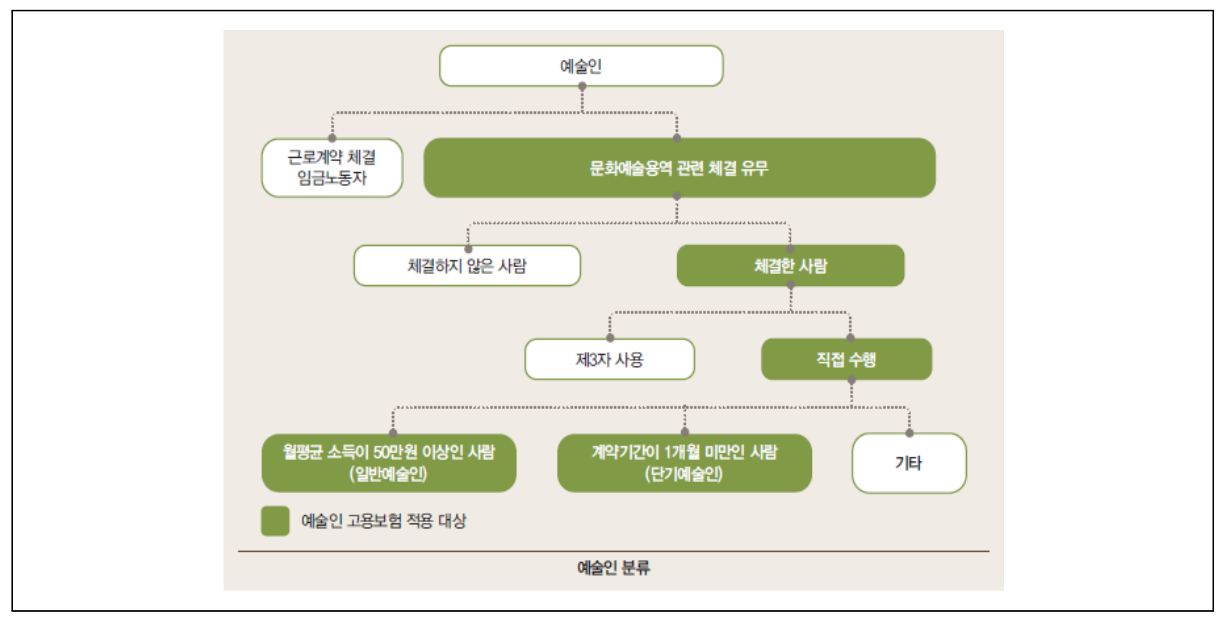

자료: 문화체육관광부(2020). 문화예술용역 운용지침서(가이드라인)

3) 문화체육관광부(2020). 문화예술용역 운용지침서(가이드라인)의 내용을 기초로 작성함 
〈표 3-2〉 예술인 고용보험과 근로자 고용보험 비교

\begin{tabular}{|c|c|c|c|}
\hline \multicolumn{2}{|c|}{ 구분 } & 예술인 고용보험 & 근로자 고용보험 \\
\hline \multirow[b]{2}{*}{ 적용범위 } & 가입 & $\begin{array}{l}\text { 문화예술용역 관련 계약을 } \\
\text { 체결한 프리랜서 예술인 }\end{array}$ & 근로자(일용근로자 포함) \\
\hline & 제외 & $\begin{array}{l}\text { - 월평균소득 } 50 \text { 만원 미만 } \\
\text { (단, 단기예술인 소득기준 미적용) } \\
\text { - 65세 이후 신규 }\end{array}$ & $\begin{array}{l}\text { - 주 15시간 미만 } \\
\text { - 65세 이후 신규 }\end{array}$ \\
\hline \multirow{2}{*}{ 피보험자 관리 } & 취득신고 등 & $\begin{array}{l}\text { 사업주 } \\
\text { *소득을 합산하여 가입할 경우 예술인 }\end{array}$ & 사업주 \\
\hline & $\begin{array}{c}\text { 가입기간 } \\
\text { (피보험자격) }\end{array}$ & $\begin{array}{l}\text { 문화예술용역 관련 계약 } \\
\text { 기간(노무제공기간) }\end{array}$ & 근로계약 기간 \\
\hline \multirow{3}{*}{$\begin{array}{l}\text { 보험료 납부 } \\
\text { (월평균 보수 } \\
\text { *보험료율) }\end{array}$} & 보수 & $\begin{array}{l}\text { (사업소득 + 기타소득 })- \\
\text { 비과세소득 - 경비 } \\
\text { *기준경비율 20\% 적용 }\end{array}$ & 근로소득 - 비과세소득 \\
\hline & 보험료율 & $\begin{array}{l}\text { 실업급여 } 1.4 \% \\
\text { *21년 7월 1일부터 1.4\% 적용, } \\
\text { 이전 1.6\% }\end{array}$ & $\begin{array}{l}\text { 실업급여 } 1.6 \% \\
\text { 고용안정·직업능력 0.25 0.85\% }\end{array}$ \\
\hline & $\begin{array}{l}\text { 보험료 } \\
\text { 납부자 }\end{array}$ & 사업주 & 사업주 \\
\hline \multirow{5}{*}{$\begin{array}{l}\text { 구직급여 } \\
\text { (실업급여) } \\
\text { 지급 }\end{array}$} & 수급요건 & $\begin{array}{l}\text { 이직 전 24개월 중 피보험 } \\
\text { 단위기간 9개월 이상 }\end{array}$ & $\begin{array}{l}\text { 이직 전 } 18 \text { 개월 중 피보험 } \\
\text { 단위기간 } 180 \text { 일 이상 }\end{array}$ \\
\hline & 이직사유 & $\begin{array}{l}\text { 비자발적 이직 } \\
{ }^{*} \text { 소득감소에 따른 이직 일부 인정 }\end{array}$ & 비자발적 이직 \\
\hline & 지급수준 & $\begin{array}{l}\text { 이직 전 } 12 \text { 개월 보수총액 기준 산정 } \\
\text { 구직급여 기초일액의 } 60 \%\end{array}$ & $\begin{array}{l}\text { 평균임금 기준 산정 } \\
\text { 구직급여 기초일액의 } 60 \%\end{array}$ \\
\hline & 지급기간 & 120 270일 & 120 270일 \\
\hline & $\begin{array}{l}\text { 수급기간 중 } \\
\text { 소득활동 } \\
\text { 인정 여부 }\end{array}$ & $\begin{array}{l}\text { 수급기간 중 소득발생 시 } \\
\text { 일부 감액 혹은 전부 지급 }\end{array}$ & $\begin{array}{l}\text { 수급기간 중 취업한 날에 } \\
\text { 대해 구직급여일액 전부 감액 }\end{array}$ \\
\hline $\begin{array}{l}\text { 출산전후(휴가) } \\
\text { 급여 지급 }\end{array}$ & 지급내용 & 출산전후 급여 & 출산전후 휴가급여 \\
\hline $\begin{array}{l}\text { 고용안정직업 } \\
\text { 능력 개발사업 }\end{array}$ & 적용여부 & 미적용 & 적용 \\
\hline
\end{tabular}

자료: 예술인 고용보험 홈페이지(http://artinsure.kawf.kr)

예술인 고용보험의 당연 적용 대상이 되는 예술인은 (1) 근로자가 아니면서 (2) 「예술인 복지법」 제2조 제2 호12에 따른 예술인 등 대통령령이 정하는 사람 중 (3)예술인 복지 법」 제4조의 413 에 따른 문화예술용역 계약을 하고 (4) 다른 사람을 사용하지 않고 자신 이 직접 노무를 제공하는 사람이다. 「예술인 복지법」 제2조 제2호에 따른 예술인 등 대 
통령령이 정하는 사람으로 별도 정의한 이유는 예술활동 실적을 증명할 수 있는 「예술인 복지법」 상 예술인 뿐 아니라 예술활동 실적을 증명할 수 없는 예술인도 보호하기 위한 차원이다. 이 때문에 대통령령은 예술활동을 증명하기는 어려우나 예술활동에 따른 소득 이 발생할 수 있는 경력단절 예술인과 처음으로 예술활동을 시작한 신진 예술인 등도 대상이 될 수 있도록 문화예술 분야에서 창작, 실연(實演), 기술지원 등의 활동을 하는 사람으로 규정하고 있다.

\section{다. 예술인 권리보장법 제정}

2021년 8월 31일 '예술인의 지위와 권리의 보장에 관한 법률(예술인 권리보장법)' 제 정안이 국회 본회의를 통과하였으며, 1 년 뒤부터 시행될 예정이다. 예술인 권리보장법은 예술인들의 예술창작과 표현의 자유를 보호하고 예술인의 직업적 권리를 신장하며, 예술 인의 지위를 보장하고, 성평등한 예술환경을 조성해 예술 발전에 이바지하는 것을 목적 으로 한다. 이를 위해 예술인 권리침해 행위 및 성희롱·성폭력 행위의 금지, 예술인 권리 구제기구의 설치, 피해자에 대한 구제조치 방안 등을 규정하고 있다.

특히, 그동안 근로자성을 인정받기 어려운 자유계약자인 예술인은 노동관계법령을 통 한 보호에 한계가 있고, 예술활동을 증명하기 어려운 예비, 신진예술인은 「예술인복지법 의 적용이 힘들며, 근로관계에 있지 않은 예술인은 「국가인권위원회법, 「양성평등기본 법, 「남녀고용평등법 상 성희롱의 개념이 성립되지 않는 등 기존 법률에 의해 보호를 받지 못하는 경우가 빈번하였다. 즉, 이 법을 통해 법적 보호의 사각지대에 있던 예술인 이 보호를 받게 되었다는 측면에서 큰 의미를 지닌다.

아울러 예술인 권리보장법의 적용을 받는 예술인은 예술 활동을 업(業)으로 하기 위해 교육·훈련 등을 받았거나 받는 사람까지 포함한다. 예술대학 학생 등 상대적으로 권리 보호에 더 취약한 예비예술인 등도 권리 침해행위와 성회롱·성폭력 피해로부터 보호받 을 수 있다.

예술인 권리보장법에서는 예술인의 지위와 권리를 명확히 했다. 예술 표현의 자유 보 호를 강조하고 예술인과 다른 직업과의 동등한 지위 보장을 선언했으며, 성평등한 예술 환경에서 활동할 권리, 예술 정책 정보를 제공받고 결정에 참여할 권리 등을 규정했다. 
먼저 예술표현의 자유 보장과 예술인의 직업적 권리의 보호와 증진을 위해 예술인의 권리침해 행위를 유형화하고 금지했다. 예술인의 예술 활동과 성과 전파의 방해, 예술지 원사업에서 성별·종교·장애 등을 이유로 한 차별행위, 차별을 목적으로 한 명단 작성·공 정 심사 방해를 해서는 안 된다. 우월적 지위를 이용한 예술인과의 불공정한 계약 등 불공정행위와 예술인조합 활동 방해도 금지 대상이다. 예술인은 예술 활동 또는 교육 활동과 관련해 다른 사람에 대한 성희롱-성폭력 행위를 해서는 안 되고 예술 활동·교육 업무의 지휘·감독자, 예술교육기관 종사자 등은 예술인을 대상으로 성희롱·성폭력 행위 를 해서는 안 된다.

〈표 3-3〉 예술인의 지위와 권리의 보장에 관한 법률(예술인 권리보장법)

\begin{tabular}{|c|c|}
\hline 구분 & 내용 \\
\hline 적용대상 & $\begin{array}{l}\text { 예술 활동을 업(業)으로 하기 위해 교육·훈련 등을 받았거나 받는 사람까지 포함 } \\
\text { (예비 예술인 및 학생 모함) }\end{array}$ \\
\hline 추진방안 & $\begin{array}{l}\text { - 예술 표현의 자유 보호를 강조하고 예술인과 다른 직업과의 동등한 지위 보장 } \\
\text { (직업적 권리 보호 및 증진) } \\
\text { - 성평등한 예술환경에서 활동할 권리 } \\
\text { - 예술 정책 정보를 제공받고 결정에 참여할 권리 }\end{array}$ \\
\hline 지원내용 & $\begin{array}{l}\text { 예술인 권리침해 행위 및 성희롱·성폭력 행위의 금지, } \\
\text { 예술인 권리구제기구의 설치('예술인 권리보장 및 성희롱·성폭력 피해구제 위원회') } \\
\text { 피해자에 대한 구제조치 방안(예술인보호관 지정) } \\
\text { 문체부 예술인 성희롱·성폭력 방지대책의 수립, 피해자 보호 대책 마련, 예방교육 실시 등 수행, } \\
\text { 2년마다 성희롱·성폭력에 관한 실태조사를 실시 발표 }\end{array}$ \\
\hline
\end{tabular}

문화체육관광부는 예술인 성희롱·성폭력 방지대책의 수립, 피해자 보호 대책 마련, 예 방교육 실시 등을 수행해야 하고, 2년마다 성희롱·성폭력에 관한 실태조사를 실시하고 발표해야 한다. 예술인 권리보장법은 예술계 인사를 중심으로 구성한 입법추진 특별전담 반과 수차례의 토론회, 공청회 개최 등을 거쳐 예술 현장의 의견을 폭넓게 반영해 제정 되었다. 


\section{제2절 국외 고용안전망 사례 분석}

\section{OECD 국가의 코로나 19 대응 사례4)}

코로나19로 노동시장의 위기가 발생하기 시작하면서 $\mathrm{OECD}$ 회원국들은 재택근무를 장려하거나 강력한 안전 및 보건 기준을 도입하여 근로자들의 감염 위험을 줄이기 위한 여러 조치와 정책을 마련하였다. 각 국은 격리자를 포함한 유급병가 제도를 강화하였고, 직장에 다니는 부모들의 돌봄 의무를 지원하고, 근로자와 가족이 주거지에 머물 수 있도 록 하는 조치를 마련하였다.

[그림 3-3] OECD 국가의 코로나19 대응 조치

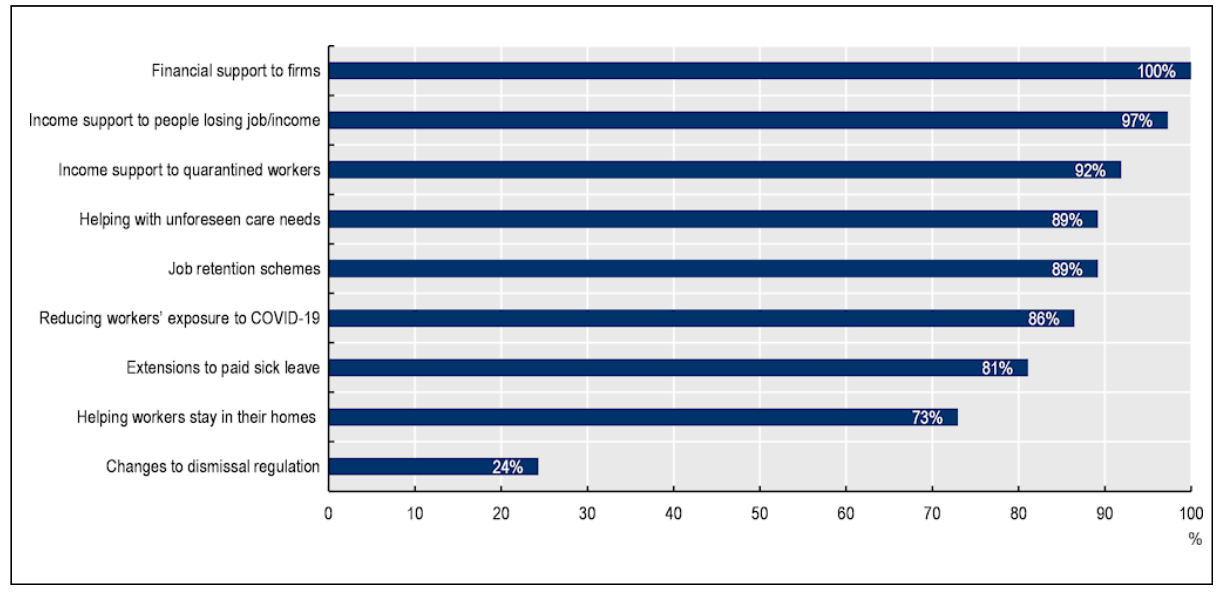

주: $\mathrm{OECD}$ 국가 전체에서 해당 조치가 나타나는 비율을 나타냄

출처: OECD(2020a). COVID-19 Employment and social policy responses by country.

4) 본 내용은 OECD(2020)의 OECD Employment Outlook 2020: Worker Security and the COVID-19 Crisis를 기초로 작성함. 
무엇보다 대부분의 $\mathrm{OECD}$ 국가들은 사업이 일시적으로 위축된 기업의 일자리 보존을 위해 고용유지 제도를 도입·확대하였다. [그림 3-3]과 같이 모든 $\mathrm{OECD}$ 국가들에서 나 타난 정책은 '기업으로의 재정 지원'이었다. 또한 일자리 및 소득 손실자에 대한 소득 지원(97\%), 코로나19로 인한 격리 근로자에 대한 소득 지원(92\%), 예기치 못한 돌봄 의 무 관련 지원(89\%), 고용 유지 제도(89\%), 근로자들의 코로나19 노출 최소화 정책 (86\%), 유급 병가 확대(81\%), 근로자 재택근무 지원(73\%), 해고 관련 규정 개정(24\%) 등으로 나타나고 있다. 특히 노동시장에서의 고용 위기를 최소화하고 이를 유지하기 위 한 정책 지원 및 조치는 다음과 같이 나타난다.

\section{가. 고용유지제도}

고용유지제도(job retention schemes)는 많은 $\mathrm{OECD}$ 국가에서 코로나19로 인한 고 용 피해를 방지하고, 다수의 정리 해고를 방지하기 위해 실시한 주요 정책 수단이다. 코 로나19로 일시적으로 사업 활동이 위축된 기업의 일자리를 보존하고자 설계된 고용유지 제도는 기업들의 인건비 부담을 낮추고, 근로시간이 줄어든 근로자들의 소득을 지원하는 역할을 한다. 이 제도는 short-time work의 형태를 취하거나, 일하지 않은 시간에 대해 직접 보조금을 제공하는 일시적 해고제의 형태로 시행될 수 있다. 혹은 일한 시간에 대 한 보조금을 지급하고 줄어든 근로시간에 대해 근로자의 수입을 보충해 주는 네덜란드 의 긴급 브리징 조치(Noodmatregel Overbrugging Werkgelegenheid)나 호주의 일 자리 유지 보조금(job keeper payment)과 같은 임금 보조금의 형태로 나타나기도 한 다(OECD, 2020c; 이경희·김영아, 2020). 제도별 기업과 근로자에 대한 관대성, 가입 자격 조건, 참여 기업과 근로자에게 요구되는 사항은 각기 다르다(Hijzen \& Venn, 2011).

고용유지제도는 근로자의 업무가 중단되더라도 고용 계약이 유지된다는 점이 핵심이 며, 이를 통해 기업은 근로자들의 경험과 재능을 지속적으로 보유하면서 경제 활동이 다시 회복되면 신속하게 사업을 재개할 수 있다는 장점을 지닌다.

고용유지제도는 필요한 유동성을 제공하여 기업이 근로자 급여의 일부라도 계속 지급 할 수 있도록 하며, 일시적으로는 수익이 나지 않지만 중기적으로는 생존 가능한 일자리 의 손실을 방지하고, 기업과 근로자, 사회 전체에 많은 비용을 야기하는 정리 해고를 예 
방하는데 기여할 수 있다(OECD, 2020c). 실제 글로벌 금융 위기에서 short-time work 제도가 극심한 수요 충격으로 인한 경제적·사회적 비용을 줄이는 데 중요한 역할 을 했음이 보고되었다(Hijzen and Martin, 2013; Hijzen \& Venn, 2011). 일부 국가 에서는 고용유지 제도에 동참하는 기업들에게 참여 기간에는 정리 해고를 금지하며(예: 뉴질랜드, 폴란드 네덜란드의 경우는 제도 참여시 처음 3 개월 동안), 참여가 종료된 이후 일부 기간 동안은 해고를 금하고 있다(예: 오스트리아, 프랑스, 헝가리, 스페인).

코로나19 초기 대부분의 나라에게 가장 주요한 관심 사안은 보건 위기 대응과 더불어 노동 시장의 심각한 타격에서 기업과 근로자들이 잘 대응할 수 있도록 돕는 것이었다. 이에 많은 정부에서는 기존의 고용유지 제도를 수정 보완하거나 새로운 제도를 도입함 으로써 수혜율을 최대화하기 위해 노력하였다.

1) 독일

독일은 근로시간 단축 제도(Kurzarbeit)에 대한 접근을 좀 더 용이하게 간소화하였 다. 이전에는 근로시간에 대한 단축을 시행한 근로자가 전체 근로자의 $30 \%$ 인 기업에 한해 신청이 가능하였으나, 2020년 3월부터 전체 근로자의 $10 \%$ 만 되어도 신청할 수 있도록 유연화 하였다.

고용주는 실제 직원이 근무한 시간에 해당하는 급여와 함께 시간 단축으로 인한 순 소득 손실의 약 $60 \%$ 를 지급하고, 자녀가 있는 직원에게는 약 $67 \%$ 를 지급하게 된다. 공 공 고용서비스는 고용주에게 이에 대한 비용을 변상하고, 코로나19로 손해를 본 근무 시간에 대하여 사회보험 부담금의 $100 \%$ 를 상환해 준다. 이 보조금은 견습생과 임시직에 게도 제공되었으며, 코로나 19 로 인한 위기가 시작될 때 파견근로자에게까지도 확대되었 다. 독일 정부는 지난 2020 년 4 월, 소득 손실의 법정 대체율을 4 개월 이후부터 약 $70 \%$, 7 개월 이후부터 약 $80 \%$ 로 인상하였으며, 자녀가 있는 근로자의 경우에는 각각 $77 \%$ 와 $87 \%$ 를 적용하였다.

또한 short-time work 중 다른 일자리를 갖지 못하는 것에 대한 제약을 해제하였으 며, 근로자는 전체 금액이 이전의 수입을 초과하지 않는 범위 내에서 추가 수입과 short-time work 혜택을 모두 받을 수 있게 되었다. 일부 분야의 노동조합과 고용주는 소득 손실에 대한 법정 대체율을 최대 $90 \%$ 까지 인상하는 데 동의하기도 하였다. 


\section{2) 이탈리아}

이탈리아는 모든 분야에서 모든 규모의 기업들이 short-time work를 신청할 수 있 도록 허용함으로써 이 제도의 범위를 대폭 확장하였다. 기업은 상세 증빙 서류를 구비하 여 제출하지 않더라도 코로나19 위기로 피해를 입었다는 점을 간단히 신고하면 된다. 기업 활동이 감소하기 시작한 이후 short-time work를 4 개월 이내에 신청할 수 있 는데, 급여는 2020년 2월 말부터 소급하여 지급된다. 직원이 받는 혜택의 수준은 없어 지거나 변경되지 않고, 고용주의 short-time work 제도 비용 부담은 면제되었다. short-time work 급여는 총 임금의 $80 \%$ 를 지불하며 상한선은 최대 임금이 2천 159 유 로인 경우 998유로, 그 이상 임금은 1천 199유로로 정해져 있으며, 평균 임금을 받는 근로자의 경우, 근무시간이 0 으로 줄어들 때 실효 대체율은 약 $45 \%$ 이다(OECD, 2020c).

\section{3) 일본}

일본은 고용 조정 보조금(Employment Adjustment Subsidy) 제도의 적용 범위를 확대하고 접근 요건을 완화했다. 코로나19 위기 이전 이 보조금을 받기 위해서는 3 개월 이상 생산량이 $10 \%$ 감소해야 했으나, 코로나19 위기 이후에는 한 달에 $5 \%$ 로 대폭 낮추 었다. 그리고 근로단축시간에 보조금률을 중소기업은 최대 $100 \%$, 대기업은 $75 \%$ 까지 인 상하였다. 일본 정부는 2020 년 5월, 최대 급여를 1 인당 1 일 약 8,330 엔에서 1 만 5 천 엔으로 약 $80 \%$ 인상하였으며, 이 프로그램의 대상을 고용보험이 적용되지 않았던 비정 규직 근로자까지 확대하였다. 또한 중소기업이 근무시간 단축에도 불구하고, 고용주가 보조금을 신청하지 않아 지원 받지 못했던 근로자들을 대상으로 새로운 제도를 발표했 다. 이 경우 해당 중소기업 근로자들이 직접 신청할 수 있고, 평소 소득의 80\%를 보장받 을 수 있게 된다.

\section{4) 미국}

미국 26개 주에서는 단시간 보상제(Short-Time Compensation)를 운영하고 있다. 코로나 긴급지원 및 구제, 경제안보법(Coronavirus Aid, Relief, and Economic Security Act)을 통해 연방정부는 기존 프로그램을 사용하는 주에 STC 급여의 $100 \%$ 
를, 새로운 프로그램을 도입한 주에 50\%의 비용을 지원한다(OECD, 2020c).

단시간 보상제도 수급자는 전체 실업급여 수급자에게 지급되는 600달러의 주간 급여 인상을 4개월 동안 동일하게 받을 자격을 갖는다. 그러나 단시간 보상제도의 사용은 고 용주에 대한 낮은 재정 인센티브(근무하지 않은 시간에 대해서도 고용주는 사회보장기여 금의 일부 지급), 고용주 인식 부족, 최대 근로단축시간 제한, 행정적 병목 현상 등의 다양한 이유로 여전히 제한적인 실정이다. 이러한 문제들을 우회하고자 미국은 급여보호 프로그램(Paycheck Protection Program: PPP)을 도입했다. 이 프로그램은 코로나19 위기를 겪는 소기업들이 근로자들에게 임금 지급시 필요한 대출을 받도록 돕고, 고용과 보수의 수준이 유지된다면 대출 상환 감면도 받을 수 있게 된다. 즉, 즉각적이고 직접적 인 지원을 제공하며, 매출 감소나 근무시간의 단축 등 기업의 재정적 어려움을 전제 조 건으로 하지 않으므로 short-time work제도에는 해당되지 않는다.

코로나19로 인한 봉쇄 기간 동안 거의 모든 부문에서 이루어진 많은 사업 활동의 제 한은 기업 매출 및 재정 자원의 감소를 야기하였다. 평상시 고용유지제도는 보다 생산적 인 기업에 근로자의 재배치를 저해하기도 하는 등 평상시 제기되던 고용유지제도의 잠 재적 부작용에 대한 우려가 있다. 그러나 이번 위기의 초기 단계에서 고용이 사실상 동 결되고 정부가 부과한 제한 및 물리적 거리 두기 조치로 인해, 위기 이전 실적과 상관없 이 많은 기업이 타격을 입은 사실을 감안하면 이러한 위험은 매우 제한적인 것으로 판단 되었다(OECD, 2020c).

\section{나. Short-time work(STW) 제도}

OECD 국가 중 22개국은 코로나19 위기 이전에 short-time work제도를 갖추고 있 었던 반면, 10 개국은 이번 위기에 대응하여 새로운 제도를 도입하였다. 이 제도를 이미 갖추었던 국가들의 경우에는 코로나19 위기에 대응하기 위한 제도를 신속하게 재정비 하였다. STW 제도를 확장하기 위해 행한 나라들의 조치는 다음 세 가지 범주로 크게 유형화할 수 있다. 
1) 접근 간소화 및 적용 범위 확대(Simplifying access and extending coverage)

OECD 국가 중 19개 국가들은 short-time work에 대한 접근이 더 용이하고 신속하 도록 개선하였고, 직접적인 타격을 받은 기업의 수혜율을 높이기 위한 여러 조치들을 수행하였다. 코로나19 위기 시작 이래로 사업 활동이 감소했다면, 일본, 한국, 폴란드에 서는 정부 지원을 위한 사유서 제출 시 STW를 신청하도록 절차를 간소화하였다. 벨기 에, 프랑스, 스페인, 체코, 이탈리아 등의 나라에서는 감염병 등의 보건 위기가 불가항력 적 상황이라는 간단 신고를 통해 STW를 신청하도록 지원하였고, 노르웨이와 독일은 STW 제도 신청시 필요한 최소 허용 단축 근로시간의 자격을 완화하였다. 이탈리아에서 는 short-time work 제도가 대기업과 특정 부문에 국한되어 있었으나 전 영역의, 모든 규모의 기업까지 제도를 확대 조치하였다. 그리고 이탈리아와 프랑스와 같은 국가에서는 고용주가 제도 신청 전, 노동자 대표와 논의해야 하는 조항을 폐지하기도 하였다. 또한 많은 국가들이 온라인 접수를 활용함으로써 short-time work 제도의 신청 절차를 간소 화한 것으로 나타났다. 영국의 경우, 간단한 온라인 신청 절차를 도입하여 새로 적용한 코로나 일자리 유지 제도로 신속한 전환이 이루어지도록 촉진하였다.

\section{2) 비정규직 근로자에게 적용 범위 확대(Extending coverage to non-permanent workers)}

OECD 국가 중 9개 나라는 short-time work가 정규직뿐만 아니라 파견직, 임시직, 특정한 유형의 자영업까지도 포함할 수 있도록 가입 자격의 범위와 조건을 확대 조치하 였다. 원칙적으로 이러한 확대는 STW제도가 노동시장의 이중성을 악화시키는 위험을 줄이도록 해야 한다(Hijzen \& Venn, 2011). 하지만 기업은 STW 기간 동안 비정규직 근로자를 유지하려는 동기가 약해질 수 있으며, 이 제도가 고용주에게 직접 비용을 부과 하는 경우에는 특히 그러할 것이다(OECD, 2020c).

\section{3) 관대성 증대(Raising generosity)}

일부 국가들은 short-time work의 소득대체율을 높이고 기업의 비용을 낮추어 주어 이 제도의 관대성을 향상시키고 있는 것으로 나타났다. 실제 $\mathrm{OECD}$ 회원국 중 16 개 국 가들에서는 단축 근로 시간을 위한 대체율을 높였고, 고용주가 단축된 근로시간에 대한 임금의 일부나 사회보장기여금을 지급해야 했던 프랑스, 이탈리아, 독일 등 일부 국가에 
서 이 비용을 면제해 주었다(전체 $\mathrm{OECD}$ 국가들 중 절반가량은 코로나19 위기 이전에도 이 비용은 0 이었음). 즉, 코로나19 위기 초기 단계에서 시행되었던 높은 대체율 및 감소 된 고용주들의 비용은 여러 국가에서 채택한 조치의 잠재된 역효과 보다는 근로자와 기 업의 지원 필요성에 더 높은 비중과 관심을 두고 있음을 시사한다.

상기의 변화 조치들은 코로나 19 로 인한 일시적인 조치이나, 많은 정부에서는 필요한 현재의 제도들을 계속 유지할 것임을 밝히고 있다.

\section{다. 임시 임금보조 제도}

주로 영어권인 다수 국가들에서는 실제 일한 시간에 대한 표준 임금 보조금과 short-time work 제도의 요소들을 결합하여 한시적으로 일을 중단하게 된 근로자들에 게도 소득 지원을 제공하거나 근로시간 단축으로 발생한 소득의 손실분을 보o충해 주 는 새로운 형태의 고용유지제도를 도입하였다.

일부 국가(예: 캐나다, 호주, 뉴질랜드, 아일랜드)에서는 통상 임금의 일부를 충당하고 자 일시적인 임금 보조금 도입을 조치하였다. 캐나다는 전체 통상임금의 약 $75 \%$ 를 이 보조금 제도를 통해 보장하나(상한선 존재), 뉴질랜드와 호주의 경우 기업에 해당 보조 금을 일괄 지급하는 것으로 나타났다. 아일랜드는 근로자 소득에 따라 이 보조금의 지급 수준이 상이하게 책정되며, 최저소득자은 순통상임금의 최대 $85 \%$ 까지 지원하는 것으로 나타났다.

네덜란드의 경우, 기존의 short-time work 제도를 한시적인 임금보조금으로 변경하 였으며, 이 보조금은 short-time work 제도와 달리 매출 감소에 비례(노동시간 단축 아님)하여 지급되는 것으로 나타났다 해당 보조금의 범위는 매출 $25 \%$ 감소시 수익의 $22.5 \%$ 에서 매출 전무시 수익의 90\%까지 지급 가능하며, 근로자는 계속 평소 수입의 전액을 지급 받을 수 있게 된다.

이 임금보조금 제도는 short-time work 제도보다 비교적 시행이 용이하고, 기업과 고용주들에 유연성을 더 많이 제공하게 된다. 하지만, 재정적 어려움이나 위기를 겪는 기업들의 필요에 부합하는 지원 제공에는 한계가 제기된다. 보통 임금보조금은 기업 활 동이 약 20 30\%까지 크게 감소 시, 시행 시작점에서 기업에서 일하는 근로자들을 위하 여 지급되기 때문이다. 
기업은 보조금을 근로자가 일한 시간(순수 임금 보조금으로) 또는 일하지 않은 시간에 대한 지원으로(STW 제도로 활용) 어느 정도 사용할지 스스로 결정할 수 있다(OECD, 2020c). 이 보조금은 근로시간 단축과는 관련이 없기 때문에 기업은 근로자들 간에 근 로시간 단축이 어떻게 배분되고 이것이 시간이 지남에 따라 어떻게 변화하는지 보고할 의무가 없다(OECD, 2020c). 또한, 고려되는 모든 임금 보조금 제도는 큰 사업 활동 감 소 피해를 겪는 기업을 대상으로 하나, 캐나다, 호주, 뉴질랜드, 아일랜드의 경우 근로자 1 인에게 제공되는 보조금의 규모는 사업 활동 감소와 관련이 없으며, 네덜란드가 기업의 매출 감소에 비례하여 근로자 1 인당 보조금을 제공하고 있기 때문에 상대적으로 대상별 지원이 강화된 편으로 나타난다.

네덜란드를 제외한다면, 이 국가들은 short-time work 제도의 사전 경험이 없거나 제한적이다. 호주의 경우 short-time work 제도가 그동안 도입된 적이 없었고, 캐나다, 아일랜드, 뉴질랜드의 경우 글로벌 금융 위기시 STW 제도를 운영하긴 했지만 보편적으 로 사용되지 않았던 것으로 나타난다. 이 국가들의 경우, 보통 해고발생시 기업의 비용 부담이 낮은 편에 속하기 때문에 상당한 절차적 비용이 발생하는 이 STW 제도에 참여 하고자 하는 동기가 거의 발생하지 않기 때문이다. 이처럼 임금보조금이란 일한 시간에 대한 비용을 줄여 기업이 근로 시간을 높은 수준으로 유지하도록 돕고, 상황이 점차 개 선된다면 신속하게 근로 시간을 늘릴 수 있도록 하는 동기 요인이 될 것이다.

\section{라. 경제적 사유로 인한 해고, 부당한 해고시 근로자 보호 제도}

이탈리아는 코로나19로 인한 봉쇄 조치가 시작된 이후 경제적인 이유로 인해 발생한 집단/개별 해고를 무효화하였다. 이 해고에는 업무 재조직, 사업 활동의 축소·변경, 완전 중단을 위한 폐쇄 등의 이유로 결정된 해고가 포함된다. 또한 그리스는 경제적 이유로 인한 해고에 일부 제한 사항을 도입했지만 이러한 제한은 코로나19 지원 조치의 혜택을 받은 회사들에만 적용된다(OECD, 2020c).

스페인에서 코로나 19 와 관련된 모든 해고는 판사에 의해 무효로 간주되어 직원이 복 직되기도 하고, 부당 해고로 간주되어 직원이 근속연수 1 년당 33 일 치 임금을 보상받게 (OECD, 2020c). 프랑스는 직원이 50명 이상인 회사에서 집단 해고를 결정할 경우 해 고 의사를 당국에 고지해야 하며 이에 대한 당국의 조사가 강화될 것이라고 발표했다 
(OECD, 2020c).

코로나19로 인한 고용 불안감이 극심한 이 시기에 정규직의 해고를 제한하면 근로자 의 소득 및 수요 유지에 기여할 수 있고, 위기를 핑계로 평소 마음에 들지 않았던 근로자 를 해고하려는 몇몇 고용주들의 행동을 방지할 수 있으며, 근로자 보호에도 이바지할 수 있다. 하지만 기업의 경제적 이유로 인한 해고, 유동성지원 제도에 어려운 접근성, 높은 시간 및 비용 문제시 해고에 대한 엄격한 금지령은 추가적인 회사의 위기나 파산을 유발시킬 수 있다.

해고 금지는 고용주가 계약을 갱신하지 않음으로써 종료되는 임시 근로 계약에 대한 부담을 유발시킨다. 그리고 기간제 근로 계약 갱신의 횟수, 최대 기간의 제한은 코로나 19 팬데믹 상황 동안 갱신의 가능성을 제한할 가능성이 있다. 이와 같은 위험요인을 막 고자 스페인의 경우 임시 근로 계약이 팬데믹 위기 상황 동안에 법적인 최대의 기간에 도달해도 계속될 수 있도록 하였다. 지난 2020년 5월, 이탈리아는 임시계약의 비 갱신 사례가 급증하면서 근무 첫해가 지나더라도 기간제 고용의 계약을 갱신할 수 있는 유효 사례가 나오도록 기준 완화를 조치하였다.

코로나19로 인한 봉쇄 후, 경제적인 이유에 의한 해고 금지 조치는 관대성이 높은 고 용유지제도와 결합되면 구조조정을 저해하고 사업 회복의 속도를 지연시킬 수 있게 된 다. 몇몇 근로자들은 공공 고용서비스 제도를 활용해 재교육, 기타 지원 등의 수혜를 받 는 대신, 회생이 어려운 회사에 함께 발이 묶이게 될 수 있는 것이다. 또한 해고금지 조 치로 활동이 일정 기간 침체된 영역(예: 관광, 항공, 엔터테인먼트 등)에서 다시 빠르게 성장 가능한 영역(예: 배달 서비스, 온라인, 보건의료 온라인 등)으로 이동성이 지연되 면서 노동시장이 필요로 하는 구조적 변화가 지연되는 일이 초래될 것이다.

또한 팬데믹으로 아프거나, 돌볼 가족이 있거나, 사무실에 오거나 집에서도 일할 수 없는 근로자들의 결근 일수가 크게 증가하였다. 병에 걸린 근로자는 병가 정책이 있는 경우 이 제도에 의해 해고의 위험에서 보호된다. 하지만 고용주는 해고 사유가 아닌 질 병이라면, 근로자 개인의 귀책사유나 경제적 사유로 병가 기간 동안 직원을 해고할 수 있게 된다. 그리고 휴가 일수를 모두 소진했음에도 일터로 복귀할 수 없는 상황에서 직 원의 무단결근은 정당한 해고 사유가 될 수 있을 것이다. 이는 학교가 폐쇄되고, 가족 구성원 중 누군가가 아플 경우 문제가 될 수 있다. 또한 개인의 귀책사유에 의한 해고 대상은 재택근무 업무 효율성이 저하되는 직원, 통근중 혹은 직장 내 위생 문제 때문에 
출근을 거부하는 직원 등도 포함될 수 있을 것이다.

전술한 해고의 상황을 피하고자 이탈리아, 슬로바키아 등에서는 근로자 개인의 귀책 사유로 인한 해고시 이를 제한하는 조항들을 시도하였다. 예를 들면, 이탈리아의 경우 장애 자녀와 함께 거주하는 부모가 자녀 돌봄을 위해 결근할 경우 사전에 고용주에게 결근 의사와 사유를 설명한다면 해고의 대상이 될 수 없다. 그리고 12 16세의 자녀가 있는 부모의 경우 자녀가 휴교하는 기간 동안 일하지 않을 권리가 있으며 이때 결근은 해고 사유로 인정되지 않는다. 슬로바키아에서는 휴교 기간 중 어 린 자녀나 아픈 가족 이 있어 돌봄을 해야 하는 직원은 해고로부터 보호 받을 수 있게 된다.

\section{마. 피해 근로자에 대한 소득보장 및 고용 지원}

1) 실직자/자영업자 대상 소득 지원

많은 국가에서 고용 유지 계획의 확장, 신규 도입 노력을 수행하고, 기업에 긴급 유동 성 지원을 제공하여 일자리 보호를 위해 과감한 조치들을 수행하였으나, 전 $\mathrm{OECD}$ 국가 내 수백만 명의 근로자들이 일자리를 잃는 사태가 발생하였다. 미국의 경우, 2020년 3 5월 사이 근로자 약 4천만 명 이상이 신규 실업 급여를 청구했을 정도이다. 더 많은 사람들이 일자리를 상실했지만, 실업자로 등록되지 않거나 근무시간이 매우 단축되었다.

한편, 대다수 자영업자의 경우 코로나 19 로 인한 이동제한 조치 기간 중 사업체 운영 을 대폭 축소하고나 중단하였기 때문에 막대한 소득 손실을 겪었다. 이때 실업급여나 기타 실직자 지원 프로그램은 실직, 자영업 소득의 극심한 하락으로 피해를 당한 가구들 의 소득 손실을 완화하는 역할을 하였다. 글로벌 금융 위기시처럼, 이러한 프로그램들은 경제적 어려움 해소에 필수 역할을 하며, 총 수요를 증대시켜 경제적 안정화에 기여한다.

\section{2) 정규직 근로자 실직 시, 소득 지원}

대다수 $\mathrm{OECD}$ 국가에서 근로 기간이 명시되지 않은 전일제 고용 형태인 '정규직' 근 로자는 일자리, 소득 손실을 입더라도 소득 보장이 비교적 잘 되고 있다. 실업보험급여 는 보통 실업 초기 단계의 첫 번째 지원책으로, 이전 소득의 일정 정도를 명시된 기간 동안 대체해 준다. 
또 일부 국가에서는 근로, 기여 이력이 부족하거나 급여의 수급 자격이 소진된 구직자 들을 대상으로 실업부조 제도를 운영하고 있는데 실업보험급여보다 관대성이 떨어지는 지원을 제공하고 있다. 저소득 가구의 구직자의 경우, 사회부조와 같이 비기여 및 자산 조사형 급여인 최저소득급여를 받을 자격이 있을 수도 있다(OECD, 2019). 2019년 $\mathrm{OECD}$ 고용 전망(OECD, 2019)에 따르면, 조사된 유럽의 17개 OECD 국가 대부분에 서 과거 전일제로 근속한 실업자의 대다수가 2014/5년에 어떤 형태로든 소득 지원을 받을 수 있었으나, 적용 범위에 상당한 격차가 있다. 그리스와 이탈리아의 정규직 근로 자 중 약 $50 \%$, 폴란드에서는 약 $60 \%$ 만이 실직 후 어떤 형태로든 소득지원을 받았다 (OECD, 2020c). 또한 보장을 받는다 하더라도 상당한 소득 감소를 겪을 수 있다. 예를 들어, $\mathrm{OECD}$ 국가 약 두 나라 중 한 나라에서 소득 수준이 보통이었던 실업자가 실업 초기 단계에서 받는 실직자 지원금은 과거 순소득의 3 분의 2 보다 적은 수준이다(OECD, 2020c).

\section{3) 비정규/비공식 근로자 대상 적용 범위의 한계}

비정규직 형태에 종사하는 근로자는 평균적으로 정규직 형태보다 기존 사회보장제도 에서 제공받는 혜택이 제한적이다. OECD 고용 전망 2019에 따르면, 자영업, 단기 또는 시간제 고용에 종사하는 사람들은 정규직 근로자에 비해, 실직 기간 동안 어떤 형태로든 소득 지원을 받을 가능성이 적다(OECD, 2020c).

체코, 에스토니아, 라트비아, 포르투갈, 슬로바키아와같은 일부 국가에서는 정규직 근 로자 대비 적용 범위 격차가 40 50\%에 이른다(OECD, 2020c). 자영업자에게 그 격차 가 더 커지는 경향이 있지만, 시간제 근로자 그리고 고용과 실업 상태를 빈번히 오가는 사람들 역시 실직자 지원을 받기는 어려운 편이다(OECD, 2020c). 따라서 코로나19 위 기 이전부터 이미 많은 국가에서 변화하는 노동 환경에서 실업 지원에 대한 접근성을 강화하는 방법을 모색해 오고 있었다(OECD, 2020c).

비공식 근로자들은(미등록 이주민 포함) 기여형 소득 지원 제도 지원의 범위를 벗어난 다. 여기에는 의무적 사회보장 제도에 등록되지 않은 근로자, 법정 최저임금보다 적은 급여를 받는 근로자, 서면 계약 없이 고용된 근로자(그렇게 하는 것이 법적 요건인 나라 의 경우), 세금을 이유로 소득의 일부 또는 전부를 신고하지 않은 자영업자(예: ‘현금 장 
사')가 포함된다(OECD, 2020c). 고용이 등록되어 있지만 보수의 일부를 현금('월급 봉 투')으로 받는 '부분 비공식' 근로자의 경우 일부 수급 자격이 있을 수 있지만 소득 손실 전체에 대한 보상을 받지는 않는다(OECD, 2020c). 그 결과, 비공식 근로자 비율이 훨 씬 높고, 인구 대다수가 공식적인 사회보장제도에 접근할 수 없으며 자택에서 대피할 경제적 여유조차 없는 신흥국과 개발도상국에서 현재의 보건 및 경제 위기가 복합적으 로 가구에 미치는 영향은 훨씬 더 극심하다(OECD, 2020c).

\section{바. 코로나19 위기 중 실업급여 확대}

$\mathrm{OECD}$ 국가의 절반 이상이 코로나 19 위기 초기 몇 주 동안 ' 1 차 단계' 인 실업보험 또는 '2차 단계' 인 실업부조급여의 접근성 및 관대성을 향상시키기 위한 조치를 취했다 (OECD, 2020c). 이러한 조치는 주로 실직한 정규직 근로자에게 혜택을 주었지만, 일부 국가의 경우 일반적이라면 자격이 인정되지 않았을 비정규직 근로자와 같은 집단에도 일시적으로 혜택을 열어 주었다(OECD, 2020c). 이러한 조치들은 다음의 세 가지 유형 으로 크게 분류된다.

1) 실업급여에 대한 접근성 및 적용 범위 개선(Improving access to and coverage of unemployment benefits)

$\mathrm{OECD} 16$ 개국은 최소 기여 요건을 완화 또는 완전히 면제해 주거나(예: 핀란드, 이스 라엘, 노르웨이, 스페인, 스웨덴), 고용 요건과 관련된 자격 기간을 연장하거나(예: 프랑 스, 스위스), 또는 이전에 자격이 없었던 집단에게도 혜택을 보장해 줌으로써 실업보험 에 대한 접근성을 개선했다(OECD, 2020c). 그러한 집단에는 자영업자(핀란드, 미국), 수습기간 동안 계약이 종료된 근로자(스페인), 무급휴가자(이스라엘), 그리고 새로운 일 자리 제안을 받고 직장을 그만두었으나 위기 발생으로 취업하지 못한 근로자(예: 벨기에, 프랑스, 스페인)가 포함된다(OECD, 2020c).

캐나다, 라트비아, 아일랜드, 뉴질랜드, 슬로베니아는 신규 실업부조급여를 도입했으 며, 콜롬비아는 지난 3 년 동안 실업급여를 전혀 받지 못한 구직자에게 이례적인 급여를 지급했다(OECD, 2020c). 호주는 자국 실업급여 제도의 자산 조사를 일시적으로 완화 했다. 또한 많은 국가에서 수급자에 대한 '적극적 구직' 조건 및 관련 활동 요건을 유예 
하거나 완화했다(OECD, 2020c).

2) 실업급여 지급 기간 연장(Extending unemployment benefit durations)

$\mathrm{OECD} 12$ 개국은 최대 실업급여 지급 가능 기간을 연장했다. 일부 나라는 기간이 만 료되는 모든 청구 건들을 특정 시점까지 자동으로 연장했고(예: 룩셈부르크, 포르투갈, 스페인의 경우보건 위기 또는 비상사태 종료까지; 노르웨이의 경우 6월 말까지), 다른 나라들은 구체적인 연장 기간을 정했다(예: 그리스, 이탈리아, 슬로바키아는 2개월, 독일 과 스위스는 3 개월, 덴마크와 프랑스는 보건 위기 지속 기간만큼)으며, 미국의 연방정부 는 실업급여 지급 기간을 최장 9개월까지 연장했다(OECD, 2020c). 그리고 대다수 국 가에서 실업 첫날부터 지원을 제공하고자 급여 대기 기간을 폐지하였다.

3) 실업급여의 관대성 증대(Raising unemployment benefit generosity)

$\mathrm{OECD} 10$ 개국에서 일시적으로 급여 수준을 높였다. 호주는 실업급여 수급자에게 6 개월 동안 2 주에 한 번씩 550호주달러를 지급하는 코로나 바이러스 보조금(coronavirus supplement)을 새로 도입했다(OECD, 2020c). 미국은 최대 4개월 동안 모든 수급자에 게 지급하는 급여를 주당 600 달러 인상했다. 이러한 일괄 인상의 결과로, 수급 자격 자 의 약 3 분의 2 가 소득 손실을 초과하는 실업급여 혜택을 받게 될 것으로 추정된다 (Ganong, Noel, and Vavra, 2020).

노르웨이는 이전 소득에 따라 대체율을 $80 \%$ 또는 $62.5 \%$ 로 높였다. 스웨덴은 100 일 에 대한 급여 하한선(약 $30 \%$ 증가)과 상한선(약 $40 \%$ 증가)을 모두 인상했다(OECD, 2020c). 오스트리아, 뉴질랜드, 영국은 실업부조 제도의 급여 수준을 높였으며, 콜롬비 아는 이례적인 실업급여를 지급했다(OECD, 2020c). 벨기에는 3개월 동안 급여대체율 의 자동 감소를 동결했으며, 핀란드는 실업급여 수급자에 대한 소득 공제를 도입했으며, 프랑스는 실업급여 수준 계산법을 변경하는 개혁의 일부를 연기했다(OECD, 2020c).

\section{사. 비정규직 근로자를 위한 조치}

이번 위기는 실업급여제도나 고용유지제도와 같은 소득대체 제도의 혜택을 받지 못하 는 근로자와 가구에 대한 지원을 강화할 수밖에 없는 긴급한 상황을 야기했다. 위기를 
통해 지금까지 소득 손실의 타격을 가장 많이 받은 집단 중 하나인 비정규 및 비공식 근로자에 대한 기존의 사회보장 격차가 고스란히 드러나고 부각된 것이다(OECD, 2020c). 적절한 지원 없이 이들 중 다수는 극심하고 장기적인 소득 부족에 시달릴 것이 며, 모아둔 돈이 없을 경우 경제적 어려움에 직면 할 위험이 있다(OECD, 2020c). 이들 은 근로시간이 제한적이거나 불규칙적이라서 고용유지제도나 실업급여제도 혜택 자격을 인정받지 못하는 경우가 많다(OECD, 2020c). 또한 미국, 핀란드, 프랑스, 영국에서 볼 수 있듯이, 소득 손실에 직면한 많은 시간제 직원을 비롯한 저소득 근로자들은 근로 연 계 급여(in-work benefits)를 통해 소득 보충급여 수급 자격을 상실할 수도 있다 (OECD, 2020c). 이 위기에 대응하고자 OECD 가입 국가들은 사각지대에 놓인 근로자 와 저소득 가구를 대상으로 다음과 같은 조치들을 시행하였다.

\section{아. 구직자/근로자를 위한 고용서비스 및 훈련 지원}

각 국에서 구직자 수가 전례 없이 증가하고, 기업이 고용유지제도를 대대적으로 사용 함에 따라 급여 관리 기관과 고용서비스는 엄청난 도전에 직면하였다(OECD, 2020c). 많은 $\mathrm{OECD}$ 국가들은 구직자들이 조기에, 집중적으로 일자리를 찾도록 유도하고자 명 시적 구직 활동 보고 절차를 갖추고 있다. 여러 국가의 공공 및 민간 고용서비스(Private Employment Services, PES)는 위기 동안 구직 활동 및 보고 요구 사항을 유지했으나, 일부 나라에서는 보육시설이나 학교 폐쇄로 집에서 자녀를 돌봐야 하는 구직자 또는 격 리된 구직자에게는 이러한 요구 사항을 완화 또는 조정해 주었다(예: 오스트리아, 브뤼 셀(벨기에), 네덜란드, 영국)(OECD, 2020c). 많은 PES는 일시적으로 구직 활동 요건을 폐지하고, 제재를 해제하기도 했으며(예:프랑스, 독일, 포르투갈, 슬로베니아, 스웨덴), 어떤 나라들은 제재를 적용하지는 않았지만 구직자들이 적극적으로 구직 활동을 계속하 도록 장려했다(예: 호주, 덴마크, 에스토니아, 라트비아)(OECD, 2020c).

또한 현 위기는 구직자들과 직장이 폐쇄되었지만 재택근무를 할 수 없는 유휴 상태의 근로자 모두에게 숙련도 향상 또는 재숙련화의 기회를 제공하고 있다(OECD, 2020c). $\mathrm{OECD}$ 국가 대부분의 PES는 물리적 거리 두기를 존중하기 위해 대면훈련 제공을 중단 해야 했지만 많은 곳에서 디지털 형태로 훈련을 제공한다(OECD, 2020c). 기존에 갖추 어 둔 온라인 훈련 솔루션을 통해 많은 국가에서 최소한의 투자로 쉽게 온라인으로 습득 
가능한 기술에 대한 훈련을 계속 제공할 수 있었다(예: 오스트리아, 벨기에, 덴마크, 에 스토니아, 네덜란드, 이탈리아 일부 지역)으며, 일부 국가에서는 온라인 교육 옵션도 신 속하게 강화했다(OECD, 2020c). 예를 들어, 덴마크는 지방자치단체에서 새로운 디지 털 자격 취득 과정을 제공할 수 있도록 법안을 개정했으며, 프랑스는 Emploi Store에서 150 개가 넘는 새로운 온라인 교육과정을 제공하였고, 스웨덴은 PES 및 기타 주요 기관 에 할당된 추가 자금의 일부를 사용해 원격 교육 및 인터넷 기반 교육을 강화할 예정이 다(OECD, 2020c).

한편 다양한 국가의 정부/비정부 관계자들은 즉각적 수요 압력을 타개하고자 신속하 게 교육 과정을 개발하기도 하였다. 여기에는 팬데믹 대응을 위한 보건 전문가 숙련도 향상 지원이 포함된다. 예를 들어, 영국보건교육(Health Education England)은 영국 의 보건 인력을 대상으로 감염 예방 및 통제, 개인 보호 장치나 호흡기 장비 등의 사용에 관해 무료 e-러닝 프로그램을 제공했다(OECD, 2020c). 또한 실직자를 대상으로 보건 이나 사회복지, 제조업, 물류나 유통, 소매 등의 필수 서비스 일자리에 일시적으로 투입 될 수 있도록 돕는 재숙련화 교육과정도 있다(OECD, 2020c). 미국 매사추세츠 주의 비영리 보건단체인 파트너스 인 헬스(Partners in Health)는 1천 명에 달하는 근로자를 현재 인력 부족에 시달리는 직종인 접촉 추적관(contact tracers)으로 훈련하고 있다 (OECD, 2020c). 스웨덴의 소피아햄메트 대학(Sophiahemmet University)은 항공 산 업에서 해고된 직원을 위한 의료교육과정과 함께, 환대(서비스) 산업 종사자를 위한 노 인 간호 교육과정도 개발했다(OECD, 2020c). 여러 국가에서 최근의 사업 폐업으로 인 해 실직한 근로자들을 현재 수요가 있는 부문의 기업과 연결해 주는 온라인 도구(매칭 플랫폼 또는 기술 평가 도구)를 새로 개발하거나, 기존의 도구를 개선하기도 하고, 적극 홍보하는 노력도 펼치고 있다(OECD, 2020c).

\section{자. 비정형 노동자 실업보험 정책5)}

최근 $\mathrm{OECD}$ 국가들에서 임금근로자와 자영업자의 경계에 위치한 다양한 '종속 계약 자(dependent contractor)' 및 '독립 계약자(independent contractor)'를 사회보장 체계로 포괄하기 위한 논의를 지속하고 있다(OECD, 2019, 2020). 특히, 비정형 노동

5) 박혁·이종임·정은진(2021). 해외 주요국의 비정형 노동자 실업보험 현황, 노동리뷰 8월호, pp.21-39.의 내용을 기초로 작성함 
자(non-standard workers), 자영업자에 대한 정책 지원 체계 마련이 주요 쟁점이다(박 혁 외, 2021). 주요 국가의 비정형 노동자 등을 위한 실업 보험 운영을 살펴보면 다음과 같다.

\section{1) 독일}

독일에서 법률상 규정하는 정형 노동자는 '한 사용자와 무기한 근로관계에 있으면서 동일사용자의 사업장에 소속되어 전일 근로에 종사하는 자'로 정의되며, 비정형 노동자 는 (1) 기간제(임시) 노동자, (2) 단시간 노동자, (3) 파견 노동자, (4) 용역(하청) 노동자, (5) 미니잡(mini job) 종사자 등으로 구분된다. 비정형 노동자 또한 각종 노동보호법의 적용을 받으며 동일하게 4대 사회보험(고용보험, 연금보험, 의료보험, 요양보험) 가입 의 무를 갖는다(박혁 외, 2021).

자영업자는 임의가입 대상으로 주 15시간 이상 자영업 종사자로, 2011년 1월부터 사 회법전 제3권에 '신청에 따른 가입’ 규정을 명시함으로써 제도화되었다.

고용보험 임의 가입 대상자인 독일의 비정형 노동자 및 자영업자는 고용보험 가입시 일반 근로자와 동일한 실업급여 제도를 적용받으나, 급여수준, 보험료 등에서 차이가 있 고, 직업수준 등급에 따라 상이한 실업급여액을 수급하도록 규정하고 있다(박혁 외, 2021).

\section{2) 프랑스}

프랑스에서는 임금노동자에게 적용되는 실업급여 이외에도 별도의 특별 실업급여제 도를 운영하여 비정형노동자와 자영업자에 대한 보호 조치를 취하고 있다. 프랑스는 임 금근로자를 대상으로 하는 실업급여 이외에 문화예술 부문 단기계약직을 대상으로 하는 실업보험제도를 운영하고 있다. 특별실업보험은 문화예술공연 부문 단기 고용계약직인 앵떼르미떵(Intermittent du spectacle)6)과 프리랜서를 포함하는 영세자영업자에게

6) 앵떼르미땅의 사전적 의미는 ‘간헐적’혹은 ‘불규칙적’이지만, 일반적으로 문화예술공연 분야에서 단기간의 고 용계약을 맺고 일하는 근로자를 지칭한다. 노동법에서 앵떼르미땅이라는 직업적 지위를 정의하고 있지는 않지만, 실업보험 노사협약의 부속서 8과 10 에서 방송, 영화, 연극, 음악 등 업종 및 분야를 상세히 열거하 고 있다. 즉, 두 부속서에 포함된 업종의 기업 및 고용주가 해당 업무에 종사할 단기계약직을 체결한 경우 이들 피고용인을 앵떼르미땅이라고 명명한다(박혁·이종임·정은진, 2021). 
적용하는 제도로, 앵뗴르미떵에게 적용하는 특별실업급여제도는 부속협약 A8(기술직; 녹음, 영화제작, 방송, 공연 제작종사자 등)과 $\mathrm{A} 10$ (예술직; 공연예술인)에 기술된 직종으 로 제한된다.

\section{3) 일본}

일본은 1989 년 고용보험법 개정으로 고용보험제도에 ‘단시간 노동 피보험자’의 개념 을 도입하였고, '1주간의 소정 근로시간이 동일한 적용사업에 고용된 통상 근로자의 주 당 소정 근로시간에 비하여 짧고, 노동대신(장관)이 정한 시간(33시간) 미만인 자'로 정 의하였다(박혁 외, 2021).

2009년 비정규직 실업 문제가 심각한 사회문제로 대두되면서 피보험단위기간을 12 개월에서 6 개월로 완화하고, 단시간 노동의 고용유지 예상 기간을 1 년에서 6 개월 이상 으로 완화하였다. 2010년에는 고용유지 예상 기간을 6개월 이상에서 31일 이상으로 대 폭 완화함으로써 적용범위를 확대하였다(박혁 외, 2021).

일본은 '개인 취업자'라는 개념이 존재하는데, 창업자, 위탁형 취업자, 프리랜서 등을 개인 취업자로 규정하고 있으며, 보수를 얻기 위해 기업으로부터 위탁을 받아 주로 스스 로 업무에 종사한다는 개념을 포괄하고 있다. 개인 취업자에 대한 논의는 대부분 근로시 간 및 보수 등 근로 조건과 관련하여 진행되었으나, 최근에는 논의 대상이 프리랜서로 확장되면서 플랫폼을 매개로 한 개인 취업자까지도 포함하여, 실제로 실업 상태에 놓인 프리랜서의 소득보장에 관한 논의가 이루어지고 있다(박혁 외, 2021). 


\section{2. 관광 분야 정책대응 사례 분석}

UNWTO(2020.06)의 「How are countries supporting tourism recovery?」 보고 서에 따르면 전 세계 220 개 국가 및 지역 중 약 167 개국에서 코로나19 팬데믹 위기에 대응하기 위한 특별 조치와 정책을 시행하였다. 그 중 가장 즉각적이고 신속했던 정부의 조치는 경제침체를 완화하기 위한 재정적 조치로 나타났으며, 특히 중소기업의 유동성 및 가장 심각한 타격을 받는 부문의 일자리 보호에 초점을 맞추는데 활용되었다.

[그림 3-4] 전 세계 코로나19 관광분야 위기 대응 조치

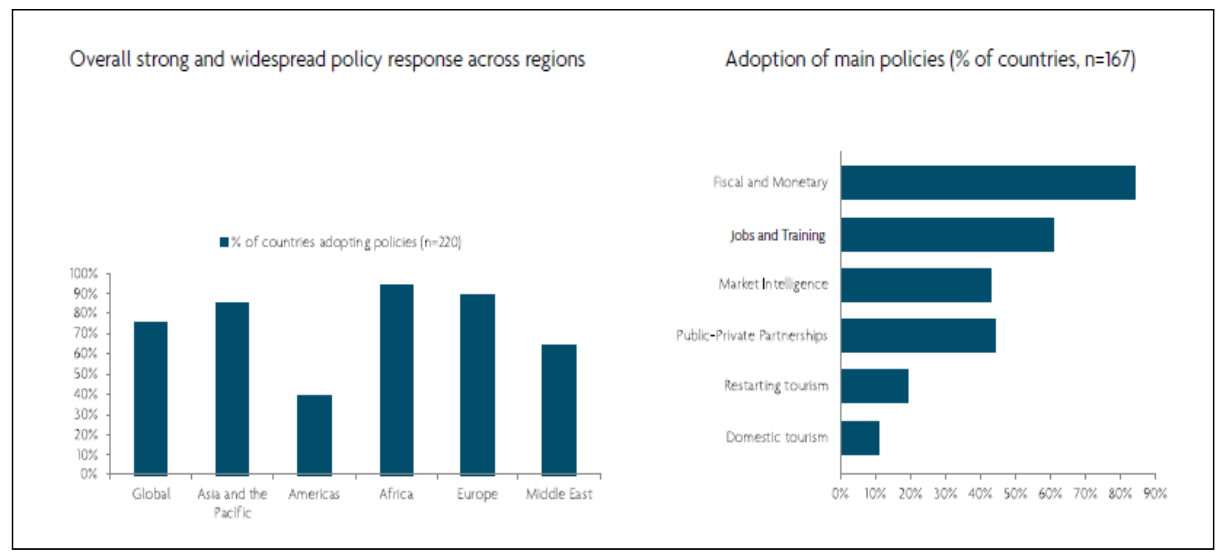

출처: UNWTO(2020.06). How are countries supporting tourism recovery?. p.6

노동집약적 산업인 여행 및 관광은 직업에 가장 큰 타격을 받은 산업 중 하나로, 관광 노동자를 보호하고 고용 유지를 보호하기 위한 몇 가지 조치들이 신속하게 채택되고 있 었다. 실업 수당을 강화하는 것 이외에, 교육 및 기술 개발, 특히 디지털 기술, 관광 기업 의 디지털 전환 및 혁신적 도구에 액세스 지원, 교육비용 충당, 근로자 재교육, 교육 부 과금 면제 및 감소 등의 정책을 실시하고 있다.

- 관광 직업 훈련에 대한 추가 부담금 감면

- 관광, 환대, 항공 산업에 속하여 있는 직업들을 보호하기 위한 임금 보조금 지원

- 수습 직원들을 위한 재정 지원

- 디지털 관련 업무에 대한 교육을 시행하는 기업들에 대한 지원

- 관광업 종사자들을 대상으로 하는 교육 지원(실업자 포함) 
- 관광업 분야 고용 지원을 위해 독립적으로 설립된 부서

- 능력 배양 프로그램

\section{가. 고용 유지를 위한 재정 지원}

불가리아 정부는 고용주가 지불해야 하는 보험료를 충당함으로써 기업(환대산업, 여 행업, 레스토랑 및 패스트푸드점 등)의 고용 유지를 지원하고 있으며, 세르비아, 슬로베 니아, 슬로바키아는 전염병으로 인해 폐쇄되어야하는 회사(또는 급여의 일정 비율)에 대 한 직접 지불을 실시하였다. 그리고 그리스에서는 노동 계약이 일시적으로 중단된 근로 자가 보상을 받는 반면, 국가는 사회 보험 및 건강 기여금을 부담하게 된다. 사회 보장 기여금 측면에서 아르헨티나, 쿠웨이트, 모로코, 몽골, 뉴칼레도니아(New Caledonia), 사모아, 헝가리에서는 고용주의 지불 부채 부담금 전체가 취소되었고, 주정부는 시간제 근로자를 지원하기 위해 3 개월 동안 손실된 임금의 $70 \%$ 이상을 지원하였다. 브루나이, 중국, 피지, 말레이시아, 뉴질랜드, 파푸아 뉴기니, 세네갈, 싱가포르 및 바누아투 (Vanuatu)도 유사한 조치를 취하였다.

가봉(Gabon)에서 기술 실업(technical unemployment)에 배치된 직원은 총 급여 의 50 70\%에 해당하는 수당을 받을 수 있으며, 튀니지는 관광수공예부(Ministry of Tourism and Handicrafts), 튀니지 호텔 연맹(Tunisian Hotel Federation), 튀니지 총 노동조합(Tunisian General Labour Union) 간 호텔 직원의 임금 지급 계약을 체 결하였으며, 이탈리아도 원천징수 중단을 승인하고, 사회보장 및 복지 기여금을 관광 부 분을 포함한 문화 사업으로 확대하였다.

나미비아 정부는 가장 큰 타격을 입은 분야인 관광, 환대산업, 여행 및 항공, 건설 분 야에서 일자리를 유지하는 기업을 돕기 위해 임금 보조금을 제공하였다. 레바논은 경제 기관이 급여 지급을 돕기 위해 5년 동안 무이자 대출을 허용하였으며, 몬테네그로는 2020년 4월과 5월 관광 부문의 급여 보조금을 기업가, 관광 중소기업에 제공하였다(요 청시 관광 기업은 급여 지급에 대한 보조금을 받게 됨). 스페인에서 정부는 일시적인 집 단 해고의 조건을 완화하고, 관광과 관련된 여행, 상업, 환대 부문에서 불연속적인 영구 계약을 맺은 근로자의 활동 기간 연장을 지원하는 조치를 도입하였다. 스웨덴도 단기 해고를 완화하였는데 중앙 정부가 비용의 더 많은 부분을 부담함으로써 고용주의 임금 
비용을 절반으로 줄일 수 있도록 돕고 있다. 일본은 고용 보호를 위해 고용 조정 보조금 을 크게 확대하였고, 세이셸 정부도 실업 구제 계획에 특별 기금을 할당하였다.

\section{나. 고용 유지를 위한 교육 지원}

모리셔스에서는 관광 부문 운영자를 위한 교육비가 일시적으로 $1 \%$ 에서 $0.5 \%$ 로 감소 되었으며, 유사한 교육비 감면이 싱가포르에서 채택되었다. 캄보디아는 해고 근로자를 대상으로 재교육 및 숙련도 향상 프로그램을 제공하고 호텔, 게스트하우스, 음식점, 여 행사에서 근무하는 근로자의 최저 임금의 $20 \%$ 를 지급하였는데 근로자는 사전에 관광부 가 제공하는 단기 과정에 참석해야 한다.

아일랜드와 포르투갈은 기업이 COVID-19의 영향을 탐색하고 위기의 영향을 받은 고용주에게 조언을 제공하는 데 도움이 되는 온라인 교육 프로그램, 워크숍, 웨비나 및 네트워킹 모임을 온라인으로 개발하였다. 특히 디지털 전환과 필요성에 특별한 주의를 기울여 디지털 기술을 업그레이드하였다. 이스라엘 관광부(Ministry of Tourism) 역시 업계의 인적 자본(예: 호텔리어, 여행사, 여행 가이드 및 기타 여행 전문가)을 보존하고 강화하기 위해 전문 웨비나 및 웹 기반 과정의 포괄적인 교육 프로그램을 운영하였다.

태국은 지속 가능한 관광 프로젝트와 기타 교육 및 기술 업그레이드 이니셔티브를 위 한 특별 지역의 커뮤니티 역량 구축을 계획하였다. 이집트 관광유물부(Ministry of Tourism and Antiquities)와 연방 관광협회(Federal Tourism Association)는 관광 에 종사하는 모든 직원에게 자기 보호 절차를 위해 따라야 할 조치에 대한 지침을 발표 했으며, 이집트 호텔협회(Egyptian Hotel Association)는 이 위기 상황에 대한 대응력 을 높이기 위한 직원 교육을 실시하고, $\mathrm{WHO}$ 가이드라인에 따라 관광부문의 대비도를 높이기 위한 예방 조치를 훈련하였다. 그리고 칠레 관광부 차관은 국가 관광청(National Tourism Service, SERNATUR)과 함께 관광 기업가를 위한 비즈니스 및 디지털 관리 프로세스에 강력한 디지털 구성 요소를 통합하는 비즈니스를 위한 기술 지원 프로그램 을 시행하고 있다. 


\section{다. 스위스 호텔업계의 단축노동}

스위스의 호텔업에서는 '단축 노동'을 위기 극복의 가장 중요한 수단으로 활용하고 있 다. 2020년 6월 스위스 호텔협회가 299개 호텔을 대상으로 한 설문조사에 따르면 “팬 데믹이 시작된 이래 유동성 문제를 해결하고 비용을 절감하기 위해 어떤 조치를 취했습 니까?”라는 질문에 전체 96\%의 호텔이 단축 노동을 실시했다고 나타냈다(Hotellerie Suisse, 2020). 즉, 대부분의 호텔 기업들이 노동시간 단축을 통해 일자리를 유지하는 조치를 취했다. 약 $64 \%$ 의 사업체가 정부의 대출금을 받은 것으로 나타났다. 지원을 받 은 회사들은 대부분의 자금을 청구서 정산과 임금 지급에 사용하였으며, 시골과 고산 지역과 달리 도시의 호텔들은 임대료를 지불하는데 사용했다.

“향후 6 12개월 동안 어떤 경제적 지원 수단이 필요하고 생각하십니까?”라는 질문에 가장 많은 대답은 “단축 노동수당을 12 개월에서 18 개월로 연장(72\%)"하자는 것으로 나 타났다. 또한 단축 노동수당을 정규직뿐만 아니라 특고와 직업교육생에게도 연장하는 것 이 필요하다는 의견도 많았다(64\% 및 28\%). 즉, 코로나19 위기를 극복하기 위해 단축노 동을 통한 일자리 유지가 가장 중요한 위기 극복조치라고 생각하고 있음을 시사한다.

[그림 3-5] 코로나19 위기 대응을 위해 스위스 호텔에서 취한 조치

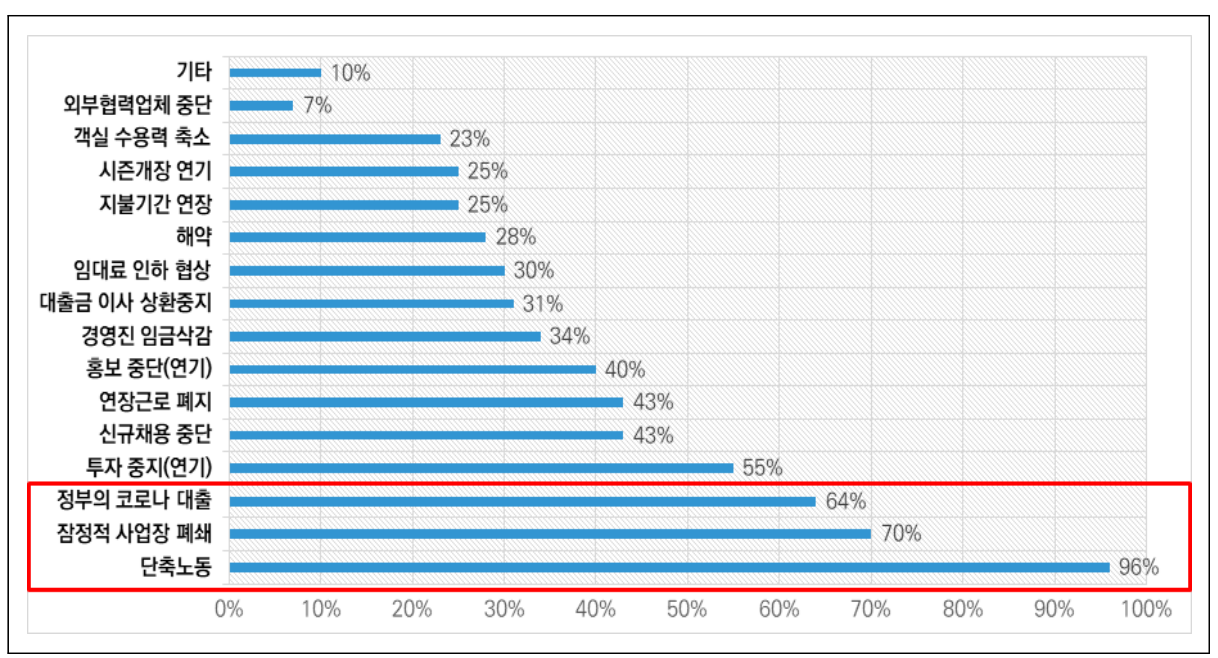

자료: Hotellerie Suisse(2020) 
응답자의 절반 이상은(57\%) 코로나19 관련 무이자 대출이 필요하다고 생각하고 있었 으며, 상당수는 코로나19 기간 동안 코로나19 대출 상환 면제도 요구하고 있다(43\%).

[그림 3-6] 향후 필요한 정책 및 조치에 대한 의견

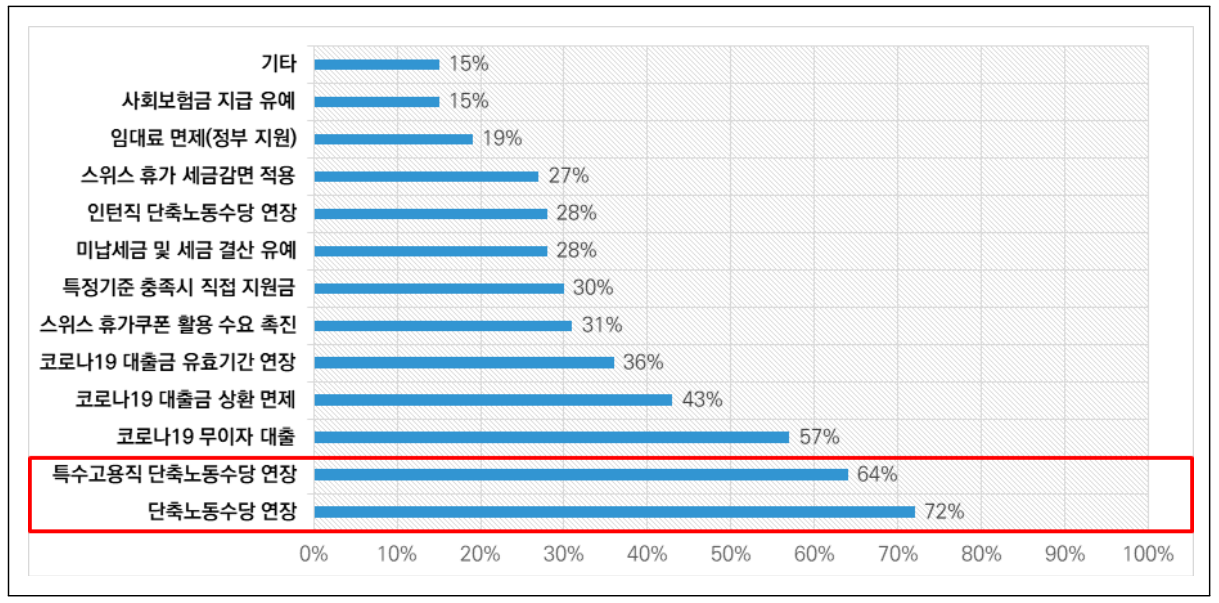

자료: Hotellerie Suisse(2020)

\section{라. 북아일랜드(Norther Island) 임시 고용유지 정책}

북아일랜드의 Cleaver Fulton Rankin Solicitors의 고용 및 비즈니스 이민팀에서 2020년 3월 1일부터 10월 31일까지 시행한 코로나19로 인한 임시적인 고용유지 정책 (temporary job retention scheme)은 다음과 같다.

- 대상: full time, part time, flexible or zero hours, agency workers, foreign nationals

- 3 주에 한 번씩 직원 교체 가능

- 휴가 기간 동안 고용주를 위해 어떤 업무도 수행할 수 없음(단, 전액 급여로 교육을 수행할 수 있음)

- 해고된 근로자에게 최대 $£ 2500$ 까지 지급

- 고용주 NICs 및 해당 무급 급여에 대한 최소 자동 등록 연금 기여금을 포함

- 고용유지제도 제외: 임의 보너스 및 커미션, 비현금 결제, 급여 희생 제도(salary sacrifice schemes), 현물제도, 도제 추가금 및 학자금 대출 
- 고용 기간에 따라 지급되는 금액 상이(예: 12 개월 이상 근무 $\rightarrow 1$ 년 전과 같은 봉급, 12 개월 미만 근무 $\rightarrow$ 연평균 소득의 $80 \%, 1$ 달 미만 근무 $\rightarrow$ 2019-2020년 평균 소득)

- 월급의 $80 \%$ 미만 또는 $£ 2,500$ 을 신청했을 때 스탭은 국가최저임금(National Minimum Wage)/국가최저생계비(National Living Wage) 보다 낮은 금액을 받 을 수 있으나, 해고상태 동안 교육 중인 종사자(employee)들은 적어도 NMW/NLW 는 지급되어져야 함(고용유지제의 기금은 교육 시간까지 카운트하여 지급). 도제생들 은(apprentices) 최소 AMW(average minimum wage)/NMW/NLW을 지급

\section{마. 프랑스 투어가이드 지원 사례7)}

직업이 법에 의해 인정되고 규제되는 가이드는 프랑스의 역사 및 문화유산을 알리고 홍보하는데 주도적인 역할을 한다. 코로나19로 인한 이동제한 기간 동안 가이드 활동을 전면적으로 중지할 수밖에 없었던 관광가이드들은 일하는 장소(박물관, 기념물, 관광지, 도시, 예술과 역사 국가 등)에 방문객들이 끊겨 매우 어려운 상황에 처해 있다. 특히, 외국인 관광객의 부재는 관광가이드들에게 더욱 위협적이다.

이러한 어려움을 인식한 정부는 2020년 6월에 여행 가이드가 코로나19 위기로 가장 큰 영향을 받는 부문에 적용되는 지원 혜택을 계속 받을 수 있도록 결정하였다. 특히 2020년 말까지 연대 기금의 혜택을 받게 된다(최대 €1,500 지원).

관광가이드 직종에서 지속적으로 발생하는 문제해결을 위해 정부는 관광가이드를 대 표하는 3개 전문 기관의 대표들과 연합하는 부처간 실무 그룹을 구성했다. 전국 가이드. 통역 및 강사 연합(FNGIC), 전문 가이드 통역사 연맹(SPGIC), 전국 가이드 연사 연맹 (SNGC) 등이 포함된 실무 그룹 내에서 의사 결정을 진행한다.

해당 직종(직업)에 대한 이해를 높이고 지원의 필요성을 평가하기 위하여 문화부와 경 제부의 자금을 투입하여 실태조사 연구를 진행하고 있다. 프랑스 정부는 관광가이드가 코로나 종식 이후 국가 전역의 문화 활동 및 관광 재개에 중요한 역할을 담당할 것으로 인식하고, 위기 상황에서 든든한 지원자 역할을 담당하며 상호 협력하고 있다.

7) 출처: 프랑스 관광청 투어가이드 현황 보도자료(2020.09.23.) 


\section{제3절 종합분석 및 시사점}

3장에서는 고용안전망 구축 관련 주요 제도 및 국내외 시례를 살펴보았다. 먼저 우리 나라의 고용안전망을 형성하는 고용보험제도의 전반적인 내용과 산업의 위기 상황에 대 비한 고용위기 산업 지원 제도(특별고용지원업종 지정), 2020년부터 시행되는 예술인 고용보험제도의 시례를 살펴보았다. 국외의 고용안전망 사례 분석은 $\mathrm{OECD}$ 와 UNWTO 등에서 발표한 주요국의 코로나19 대응 정책사례를 살펴보았다. 해외 주요 국가에서 코 로나19로 가해진 노동시장의 충격 완화를 위하여 어떠한 정책을 제공하는지 살펴봄으로 써 향후 국내 고용안전망 정책 발굴을 위한 시사점으로 활용하였다.

전 세계적으로 유례를 찾기 어려운 코로나19 팬데믹은 대공황 이후 최악의 경제 위기 를 초래하였다. 대부분의 국가에서 사람들의 이동 및 대면 활동 제한, 국경과 공항 봉쇄 등의 정책으로 감염병 확산을 막고 있다. 사람과 사람간의 만남과 환대 서비스가 중심인 관광 분야는 코로나19의 영향으로 심각한 타격을 받고 있으며, 특히 노동시장에 큰 충격 이 가해지고 있다. 항공, 여행, 호텔·숙박, MICE 등 많은 업종에서 휴·폐업이 진행되고 있고, 고용 및 일자리 위기가 지속되고 있는 실정이다. 기업들은 채용을 동결하거나 유. 무급 휴직제도 및 정부의 고용 유지 지원금을 받으며 근로를 유보하고 있어 실질적으로 근무하는 사람의 수는 급감하였으며, 청년, 여성, 저숙련 노동자 등의 취약계층이 더욱 큰 어려움에 처해 있음이 나타나고 있다.

우리 정부도 관광. 여행, 항공 등 코로나19로 가장 많은 피해를 입은 업종을 '특별고용 지원업종 으로 지정하고 고용유지지원금을 지급하고 있다. 그러나 위기를 넘기기에는 한 시적인 기간이고, 임금 보전의 수준도 낮은 실정이다. 더군다나 실제 고용유지지원금을 받지 않고 정리해고를 택하려는 기업이 있음을 볼 때 그 효과성에 한계가 예상된다. 고 용노동부의 고용안전망 지원 정책 뿐 아니라 관광 부문에서의 지원 제도 마련이 필요한 이유가 여기에 있다. 해외의 경우 관광 부문의 고용유지를 위한 재정 지원과 교육 지원 
이 공통적으로 나타났고, 스위스 호텔업계의 단축 노동을 통한 일자리 나누기 정책, 프 랑스의 관광가이드 대상 재정 지원 정책 등은 시사하는 바가 크다.

〈표 3-4〉 국외의 고용 지원 사례 종합

\begin{tabular}{l|l}
\hline \multicolumn{1}{c|}{ 고용/노동 지원 제도 } & \multicolumn{1}{c}{ 관광 부문 지원 제도 } \\
\hline - 고용유지제도 & - 관광 직업 훈련에 대한 추가 부담금 감면 \\
- Short-time work 제도 & - 관광산업 보호를 위한 임금 보조금 지원 \\
- 임시 임금보조 제도 & - 인턴 직원들을 위한 재정 지원 \\
- 해고 근로자 보호 & - 디지털 관련 업무 교육 시행 기업 지원 \\
- 피해근로자 소득보장 및 고용 지원 & - 관광종사자 대상 하는 교육 지원 (실업자 포함) \\
- 코로나19 위기 중 실업급여 확대 & - 관광업계 고용 지원을 위한 전담부서 역량강화 프로 \\
- 비정규직 근로자 조치 & 그램 \\
- 구직자를 위한 고용서비스 및 훈련 지원 & \\
\hline
\end{tabular}

앞서 살펴보았듯, 위기 시에도 휴업이나 노동시간 단축을 통해 고용을 유지하는 것이 기업의 미래 경쟁력과 성장에 도움이 된다는 것이 나타나고 있다. 스위스 호텔협회에서 도 ‘단축노동’이 위기 극복을 위한 가장 중요한 수단으로 인식하고 있으며, 여기에는 임 금 보전을 위한 국가의 지원금(독일, 스위스의 경우 '단축노동수당')이 필수적이다. 이는 소비도 줄어들지 않게 만들어 전체 산업이 침체되지 않도록 하는 역할도 하기 때문이다. 코로나19는 새로운 불확실성의 시대를 예고한다. 코로나19 위기가 언제 끝날지도 불 분명하지만, 코로나19 위기가 끝난다 해도 다른 바이러스에 의한 팬데믹 사태는 기후변 화로 인해 지금보다 더 자주 발생할 것으로 전문가들은 예측하고 있다. 따라서 앞으로 점점 더 심화될 불확실성의 시대에 대비하기 위하여, 관광업계 종사자들이 갖는 고용불 안을 해소할 수 있는 단단한 고용안전망 정책 설계가 필요하다. 

관광산업 고용안전망 구축방안

제4장

관광산업 고용안전망 실태 분석 및

사각지대 진단 



\section{제1절 관광산업 노동시장 특성 및 변화}

\section{1. 관광산업 고용현황}

\section{가. 관광사업체 및 종사자 현황8)}

관광진흥법 상 관광사업체 수는 2012년 18,926개소에서 2019년 33,325개소로 크 게 증가하였다. 관광사업체의 증가는 허가 업종인 카지노와 지정 업종인 관광편의시설업 을 제외하고 모두 큰 폭의 증가 추이를 보였다. 특히 관광객이용시설업, 유원시설업에서 증가 폭이 크게 나타났다.

〈표 4-1〉 관광사업체 수 총괄표

(단위: 개소)

\begin{tabular}{c|c|c|c|c|c|c|c|c}
\hline 구분 & 2012년 & 2013년 & 2014년 & 2015년 & 2016년 & 2017년 & 2018년 & 2019년 \\
\hline 여행업 & 12,438 & 11,722 & 12,854 & 14,607 & 16,605 & 19,944 & 19,039 & 18,223 \\
\hline 관광숙박업 & 1,073 & 1,074 & 1,278 & 1,503 & 1,716 & 1,843 & 2,110 & 2,218 \\
\hline 관광객이용시설업 & 353 & 385 & 336 & 1,213 & 3,168 & 3,963 & 4,323 & 4,657 \\
\hline 국제회의업 & 485 & 508 & 677 & 619 & 700 & 890 & 886 & 1,040 \\
\hline 카지노업 & 17 & 16 & 17 & 17 & 17 & 17 & 17 & 17 \\
\hline 유원시설업 & 389 & 358 & 593 & 1,060 & 1,782 & 2,548 & 3,000 & 2,981 \\
\hline 관광편의시설업 & 4,171 & 4,378 & 5,014 & 4,855 & 3,708 & 3,884 & 4,077 & 4,189 \\
\hline 전체 & 18,926 & 18,441 & 20,769 & 23,874 & 27,696 & 33,089 & 33,452 & 33,325 \\
\hline
\end{tabular}

자료: 문화체육관광부·한국문화관광연구원(각 년도). 관광사업체조사

관광진흥법 상 관광산업 종사자 규모는 2012년 229,658명에서 2019년 275,619명 으로 증가하였다. 2012년부터 2019년까지 연평균 증가율은 2.64\% 수준이며, 전년 대 비 증가율은 3.0\%로 나타났다. 업종별 연평균 증가율(2012 2019)을 살펴보면, 여행업,

8) 이 연구에서 제시한 관광사업체 고용현황은 분석의 기초자료인「관광사업체조사」의 조사 대상인 「관광진흥 법」에 근거하여 등록·허가·신고·지정된 사업체만을 대상으로 한다. 
관광객이용시설업, 유원시설업은 증가한 반면, 나머지 업종은 감소 추세로 나타났다. 관 광숙박업의 경우, 사업체 수는 2012년 1,073개소에서 2019년 2,218로 증가하였으나, 종사자 수는 2012년 70,803명에서 2019년 70,658명으로 감소한 것으로 나타났다.

〈표 4-2〉 관광사업체 종사자수

(단위: 명)

\begin{tabular}{c|c|c|c|c|c|c|c|c}
\hline 구분 & 2012년 & 2013년 & 2014년 & 2015년 & 2016년 & 2017년 & 2018년 & 2019년 \\
\hline 여행업 & 69,990 & 70,574 & 69,400 & 84,558 & 98,421 & 107,209 & 99,077 & 103,311 \\
\hline 관광숙박업 & 70,803 & 63,899 & 67,465 & 70,305 & 73,631 & 71,769 & 69,926 & 70,658 \\
\hline 관광객이용시설업 & 11,882 & 13,528 & 10,671 & 11,065 & 17,421 & 25,535 & 23,154 & 23,863 \\
\hline 국제회의업 & 13,599 & 14,092 & 17,330 & 15,131 & 12,596 & 12,166 & 9,100 & 10,235 \\
\hline 카지노업 & 7,422 & 8,452 & 8,931 & 9,418 & 9,115 & 7,033 & 7,330 & 7,097 \\
\hline 유원시설업 & 14,386 & 14,441 & 17,031 & 17,224 & 23,683 & 27,561 & 26,189 & 24,811 \\
\hline 관광편의시설업 & 41,576 & 42,150 & 39,506 & 27,902 & 27,110 & 28,998 & 32,785 & 35,644 \\
\hline 전체 & 229,658 & 227,136 & 230,334 & 235,603 & 261,977 & 280,271 & 267,561 & 275,619 \\
\hline
\end{tabular}

자료: 문화체육관광부·한국문화관광연구원(각 년도). 관광사업체조사

2019년 기준, 관광산업 종사자의 업종별 구성을 살펴보면, 여행업 $37.5 \%$, 관광숙박 업 $25.6 \%$, 관광편의시설업 $12.9 \%$, 유원시설업 9.0\%, 관광객이용시설업 $8.7 \%$, 국제회 의업 3.7\%, 카지노업 $2.6 \%$ 의 구성을 보인다. 2012년과 비교하면 여행업 종사자의 비중 은 증가한 반면, 관광숙박업 종사자의 비중은 다소 줄어든 것으로 나타났다. 업종별로는 여행업과 관광숙박업 종사자가 전체의 $63.1 \%$ 로 대부분을 차지하고 있다.

[그림 4-1] 관광사업체 종사자 업종별 구성비

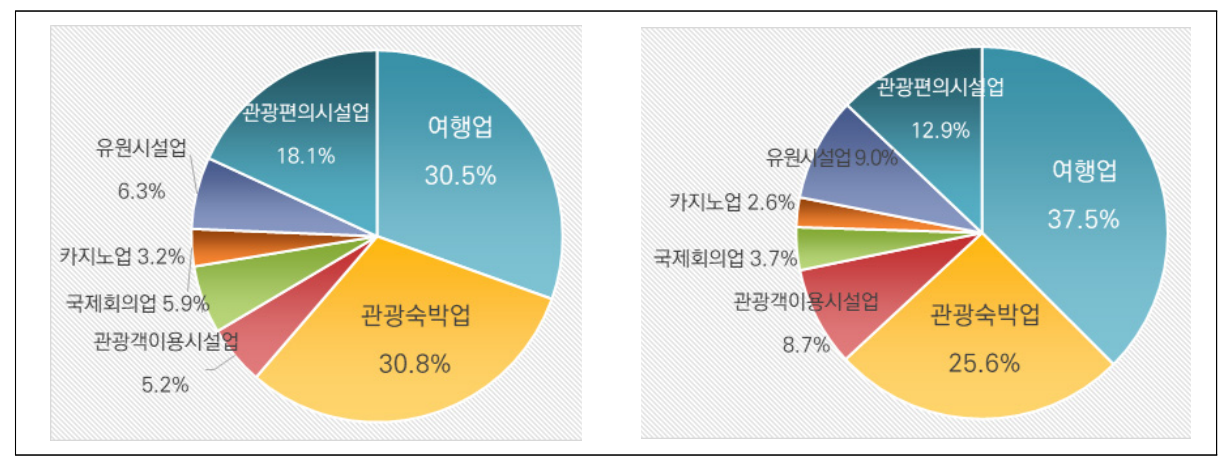

〈2012년 업종별 종사자 구성비〉

〈2019년 업종별 종사자 구성비〉 


\section{나. 관광사업체 고용형태}

관광사업체 종사자의 고용형태를 살펴보면, 임금근로자가 $94.6 \%$ 를 차지하고, 자영업 자/무급가족종사자와 무급종사자(자원봉사)는 각각 $3.3 \%, 2.2 \%$ 를 차지하였다. 임금근 로자 중 임시·일용직 근로자 비중은 약 $17 \%$ 에 달하는 것으로 파악되고 있다.

일반적으로 고용안정성을 평가하는 핵심 지표는 비정규직(임시직) 근로자의 비중이 다. 2019년 관광사업체 종사자 중 상용근로자 수가 208,827명으로 가장 많았으며, 임 시 및 일용근로자(40,512명), 자영업자(15,388명), 기타 종사자(5,913명), 무급가족종 사자(4,980명) 등의 순으로 나타났다. 전체 종사자 중 상용근로자가 차지하는 비중은 75.8\%로 전년 대비 0.8\%p 증가하였다. 최근 3년(2017년 2019년)간의 자료를 비교해 보면, 상용근로자의 비율은 증가하고, 임시 및 일용근로자의 비율은 감소하는 추세를 보 였다.

[그림 4-2] 관광사업체 고용형태별 종사자 수 구성비 추이

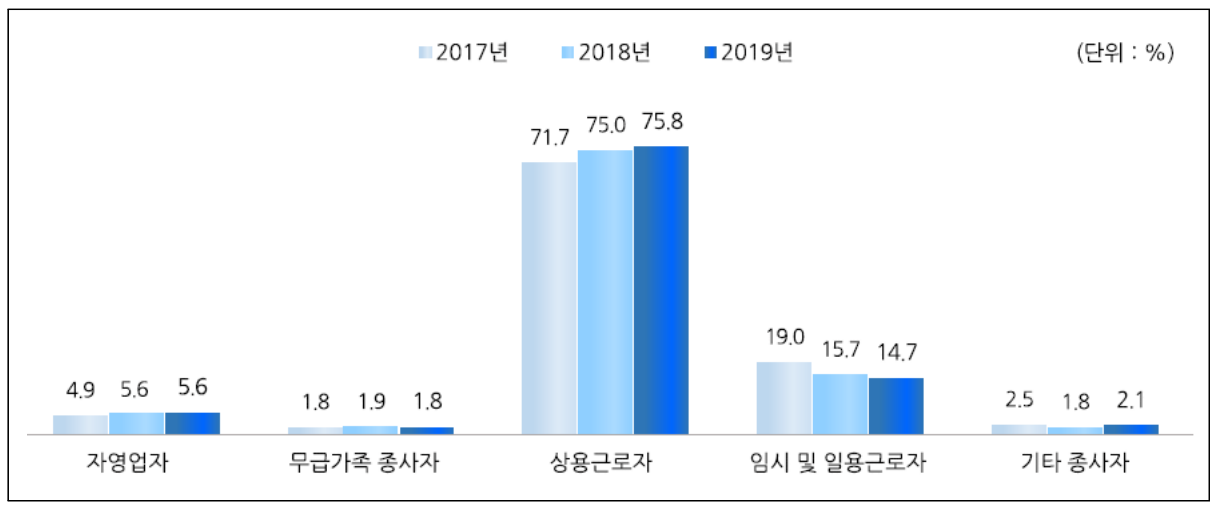

자료: 문화체육관광부 한국문화관광연구원(각 년도). 관광사업체조사

고용형태를 세부 업종별로 살펴보면 그 특징이 다양하게 나타난다. 업종별로는 소규 모 사업체가 주를 이루는 여행업과 관광객이용시설업(야영장업, 외국인관광도시민박업, 한옥체험업 등), 관광편의시설업(관광펜션업 등)에서 자영자/무급가족종사자와 무급종 사자 비중이 상대적으로 높게 나타났다. 임시·일용직 비중은 유원시설업과 관광객이용 시설업에서 높은 것으로 파악되는데, 특히 유원시설업은 전체 종사자의 $42.8 \%$ 가 임시. 일용직으로 매우 높게 나타났다. 
〈표 4-3〉2019년 세부 업종별 고용형태

(단위: 명, \%)

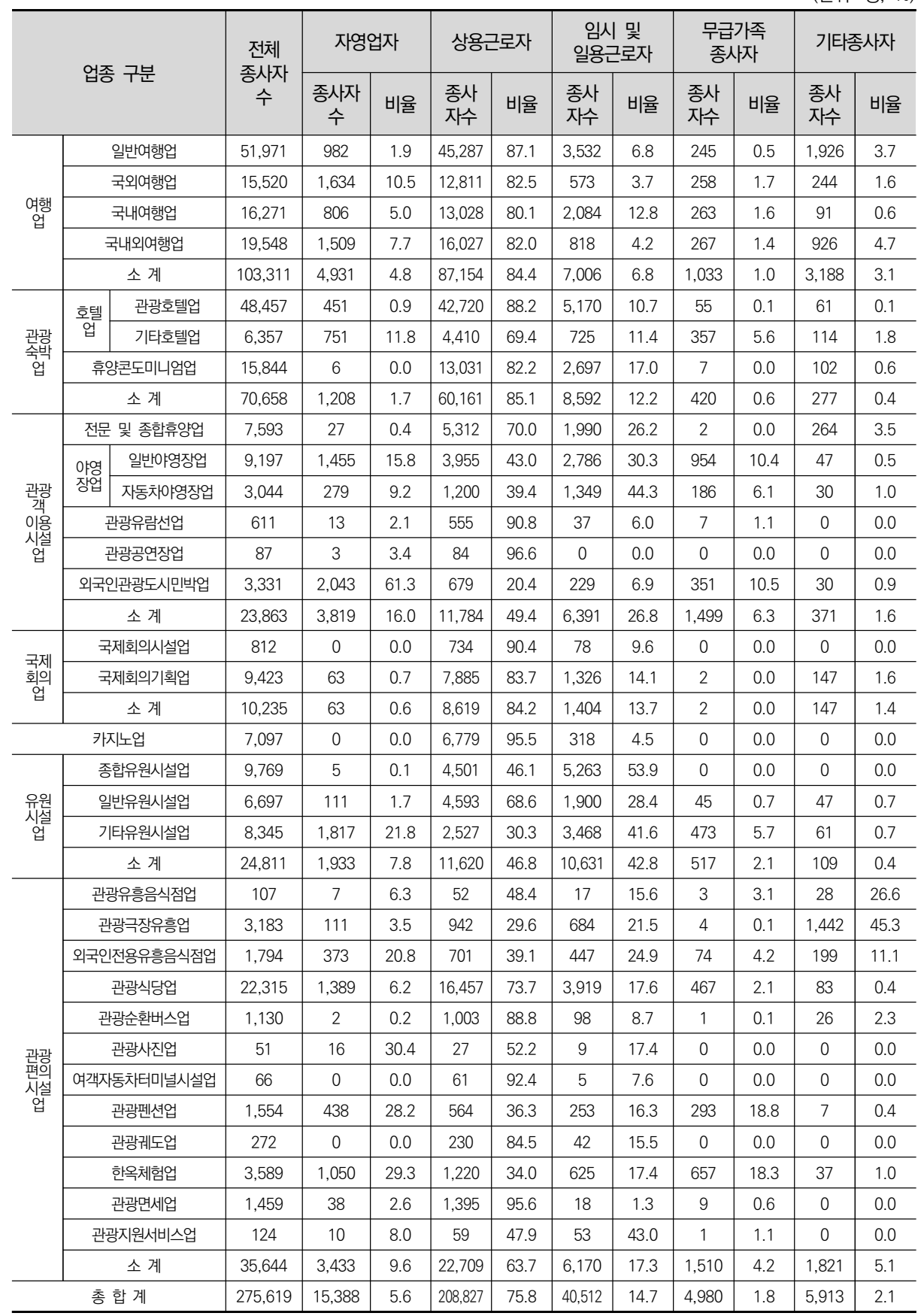

자료: 문화체육관광부·한국문화관광연구원(2020). 2019년 관광사업체조사 


\section{2. 코로나19 확산에 따른 노동시장 변화}

\section{가. 코로나19 확산 이후 관광사업체 고용 변화9)}

1) 휴직자

코로나19 확산 이후 관광사업체의 전년 대비 휴직자수를 조사한 결과, 2020년 상반 기 기준, 평균 8.8 명의 휴직자가 발생한 것으로 조사되었다. 휴직자가 없다고 응답한 사 업체는 전체의 67.8\%로, 휴직자수의 범위별로 '3명 미만'이라는 사업체가 전체의 $15.6 \%$ 로 가장 높았다. 업종별로 살펴보면, 평균 휴직자수는 '카지노업’이 181.7 명으로 가장 많았고, '관광숙박업(24.1명)', '유원시설업(14.1명)', '국제회의업(11.3명)' 순으로 나타났다. 총 휴직자수를 살펴보면 2020년 상반기 기준, 코로나19의 영향으로 여행업 종사자의 약 $52.1 \%$, 관광숙박업 종사자의 $25.7 \%$ 가 휴직 상태에 놓여있다고 해석할 수 있다.

〈표 4-4〉 전년 대비 휴직자수 변화(업종별)

(단위: 개, 명, \%)

\begin{tabular}{c|c|c|c|c|c|c|c|c|c}
\hline 구분 & 사례수 & 없음 & $\begin{array}{c}3 \text { 명 } \\
\text { 미만 }\end{array}$ & $\begin{array}{c}5 \text { 명 } \\
\text { 미만 }\end{array}$ & $\begin{array}{c}10 \text { 명 } \\
\text { 미만 }\end{array}$ & $\begin{array}{c}30 \text { 명 } \\
\text { 미만 }\end{array}$ & $\begin{array}{c}30 \text { 명 } \\
\text { 이상 }\end{array}$ & 평균 & 총휴직자수 \\
\hline 전체 & 33,325 & 67.8 & 15.6 & 6.5 & 4.9 & 3.9 & 1.3 & 8.8 & 94,197 \\
\hline 여행업 & 18,223 & 56.6 & 22.3 & 9.3 & 6.4 & 4.3 & 1.1 & 6.8 & 53,835 \\
\hline 관광숙박업 & 2,218 & 66.1 & 7.4 & 4.1 & 7.8 & 8.7 & 5.9 & 24.1 & 18,139 \\
\hline 관광객이용시설업 & 4,657 & 90.0 & 6.6 & 1.7 & 0.7 & 0.9 & 0.1 & 3.8 & 1,787 \\
\hline 국제회의업 & 1,040 & 59.4 & 11.5 & 7.6 & 10.4 & 8.2 & 3.0 & 11.3 & 4,782 \\
\hline 카지노업 & 17 & 9.1 & 0.0 & 0.0 & 0.0 & 0.0 & 90.9 & 181.7 & 2,808 \\
\hline 유원시설업 & 2,981 & 79.8 & 12.1 & 3.8 & 1.2 & 1.7 & 1.3 & 14.1 & 8,471 \\
\hline 관광편의시설업 & 4,189 & 86.7 & 4.0 & 2.8 & 2.5 & 3.8 & 0.3 & 7.8 & 4,375 \\
\hline
\end{tabular}

자료: 한국문화관광연구원(2020)

코로나19 확산으로 발생한 휴직자(94,197명) 중 무급/유급 휴직자수의 비중은, 무급 휴직자(19.3\%) 대비 유급 휴직자(80.7\%)의 비중이 높은 것으로 나타났다. 업종별로 살 펴보면, 무급 휴직자 비중은 ‘관광편의시설업(44.0\%)'에서, 유급 휴직자 비중은 ‘국제회 의업(89.7\%)'에서 상대적으로 높게 나타났다.

9) 이 조사는 2019년 기준 관광사업체 조사 대상으로 실시한 설문조사 결과로, 2020년 상반기 기준 전년 대비 응답 결과임(조사 기간 : 2020.6.11. 10.16) 
[그림 4-3] 전년 대비 무급 및 유급 휴직자수 변화

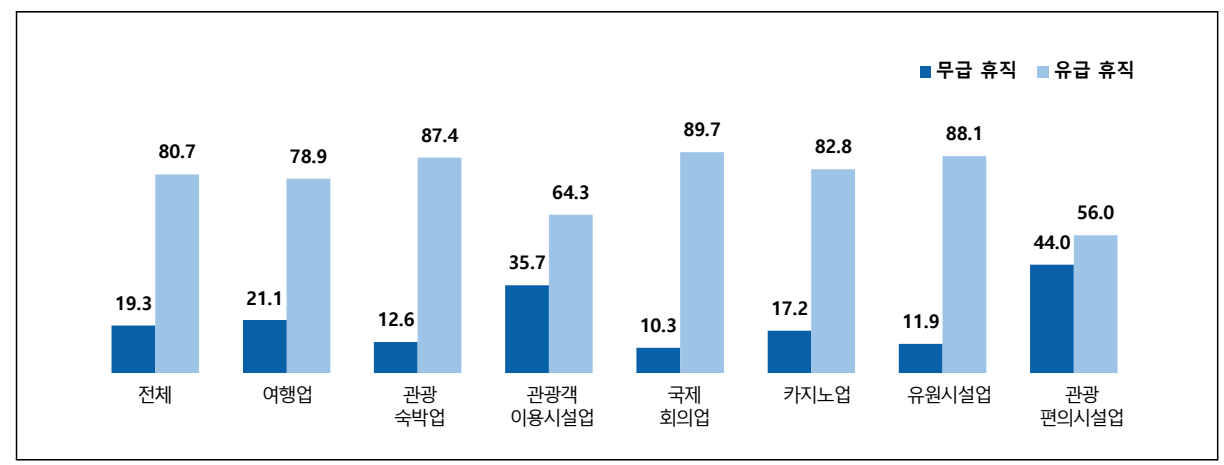

자료: 한국문화관광연구원(2020)

\section{2) 퇴직자}

2020년 상반기 기준 퇴직자수를 조사한 결과, 평균 3.7명의 퇴직자가 발생한 것으로 조사되었고, 휴직자수의 범위별로 살펴보면, ‘3명 미만’이 $16.9 \%$ 로 가장 높았다. 업종별 로 살펴보면, 평균 퇴직자수는 '카지노업(31.1명)', '관광숙박업(5.9명)', '유원시설업 (5.0명)', '국제회의업(4.3명)' 등의 순으로 조사되었다.

〈표 4-5〉 전년 대비 퇴직자수 변화(업종별)

(단위: 개, \%)

\begin{tabular}{c|c|c|c|c|c|c|c|c|c}
\hline 구분 & 사례수 & 없음 & $\begin{array}{c}3 \text { 명 } \\
\text { 미만 }\end{array}$ & $\begin{array}{c}5 \text { 명 } \\
\text { 미만 }\end{array}$ & $\begin{array}{c}10 \text { 명 } \\
\text { 미만 }\end{array}$ & $\begin{array}{c}30 \text { 명 } \\
\text { 미만 }\end{array}$ & $\begin{array}{c}30 \text { 명 } \\
\text { 이상 }\end{array}$ & 평균 & 총퇴직자수 \\
\hline 전체 & 33,325 & 73.6 & 16.9 & 4.4 & 2.9 & 1.9 & 0.3 & 3.7 & 32,894 \\
\hline 여행업 & 18,223 & 72.3 & 19.7 & 4.1 & 2.2 & 1.5 & 0.2 & 3.1 & 15,582 \\
\hline 관광숙박업 & 2,218 & 65.4 & 16.2 & 7.1 & 5.3 & 5.0 & 1.0 & 5.9 & 4,561 \\
\hline 관광객이용시설업 & 4,657 & 91.1 & 6.4 & 1.0 & 1.1 & 0.3 & 0.1 & 3.4 & 1,415 \\
\hline 국제회의업 & 1,040 & 64.2 & 19.2 & 7.9 & 4.7 & 3.7 & 0.3 & 4.3 & 1,582 \\
\hline 카지노업 & 17 & 36.4 & 9.1 & 18.2 & 9.1 & 9.1 & 18.2 & 31.1 & 337 \\
\hline 유원시설업 & 2,981 & 63.4 & 17.8 & 7.7 & 7.0 & 3.4 & 0.7 & 5.0 & 5,506 \\
\hline 관광편의시설업 & 4,189 & 74.3 & 15.5 & 4.5 & 3.1 & 2.5 & 0.1 & 3.6 & 3,911 \\
\hline
\end{tabular}

자료: 한국문화관광연구원(2020) 


\section{나. 경제활동인구조사 결과10)}

\section{1) 임금근로자 규모}

2020년 국내 임금근로자 규모는 20,446천명으로 전년 대비 $-0.5 \%$ 감소한 것으로 나 타났다. 관광 관련 산업 중 ‘숙박 및 음식점업’은 전체 산업 대비 임금 근로자 규모가 상대적으로 크게 감소하였고(-9.7\%), 특히 정규직과 비정규직 모두 약 $-10 \%$ 감소한 것 으로 나타나, 타 산업 대비 고용타격이 큰 것으로 분석된다. 한편, '사업시설 관리, 사업 자원 및 임대서비스업'과 '예술, 스포츠 및 여가관련 서비스업'은 정규직이 증가한 반면 비정규직은 감소한 특징이 나타났다.

〈표 4-6〉 임금근로자 규모

(단위: 천명, \%)

\begin{tabular}{|c|c|c|c|c|c|c|c|c|c|}
\hline \multirow{2}{*}{ 항목 } & \multicolumn{3}{|c|}{ 임금근로자 규모 } & \multicolumn{3}{|c|}{ 정규직 규모 } & \multicolumn{3}{|c|}{ 비정규직 규모 } \\
\hline & 2019년 & 2020년 & 증감률 & 2019년 & 2020년 & 증감률 & 2019년 & 2020년 & 증감률 \\
\hline 전체 & 20,559 & 20,446 & -0.5 & 13,078 & 13,020 & -0.4 & 7,481 & 7,426 & -0.7 \\
\hline 숙박 및 음식점업(I) & 1,446 & 1,306 & -9.7 & 682 & 612 & -10.2 & 765 & 694 & -9.3 \\
\hline $\begin{array}{c}\text { 사업시설 관리, 사업 지원 } \\
\text { 및 임대 서비스업(N) }\end{array}$ & 1,241 & 1,274 & 2.7 & 375 & 450 & 20.1 & 866 & 824 & -4.9 \\
\hline $\begin{array}{l}\text { 예술, 스포츠 및 여가 } \\
\text { 관련 서비스업(R) }\end{array}$ & 343 & 334 & -2.7 & 148 & 152 & 3.0 & 195 & 182 & -7.0 \\
\hline
\end{tabular}

자료: 고용노동부(2021). 2020년 8월 근로형태별 부가조사 결과

\section{2) 비정규직 근로자 규모}

2020년 비정규직 규모는 한시적 근로자를 제외하고 모두 전년 대비 증가세를 보였다. 관광 관련 산업 중 숙박 및 음식점업은 한시적 근로자(-19.8\%), 예술, 스포츠 및 여가관 련 서비스업은 시간제 근로자(-12.9\%)와 비전형 근로자(-11.2\%)가 전년 대비 $10 \%$ 이 상 감소한 특징이 나타났다. 특히 숙박 및 음식점업에서 비전형 근로자의 규모가 큰 폭 으로 늘어 전년 대비 $34.8 \%$ 증가하여, 안정적 일자리 대비 임시적 형태의 근로자가 증 가한 것으로 나타났다.

10) 경제활동인구조사 통계자료는 한국표준산업분류에 따른 대분류 업종을 기준으로 관광 연관 산업을 추출하 여 분석한 자료로, 관광진흥법 상의 관광사업과 일치하지 않음 
〈표 4-7〉 비정규직 근로자 규모

(단위: 천명, \%)

\begin{tabular}{c|c|c|c|c|c|c|c|c|c}
\hline \multirow{2}{*}{ 항목 } & \multicolumn{3}{|c|}{ 한시적 근로자 규모 } & \multicolumn{3}{c|}{ 시간제 근로자 규모 } & \multicolumn{3}{c}{ 비전형 근로자 규모 } \\
\cline { 2 - 11 } & 2019 년 & 2020 년 & 증감률 & 2019 년 & 2020 년 & 증감률 & 2019 년 & 2020 년 & 증감률 \\
\hline 전체 & 4,785 & 4,608 & -3.7 & 3,156 & 3,252 & 3.1 & 2,045 & 2,073 & 1.4 \\
\hline 숙박 및 음식점업(I) & 356 & 285 & -19.8 & 563 & 523 & -7.1 & 65 & 88 & 34.8 \\
\hline $\begin{array}{c}\text { 사업시설 관리, 사업 지원 } \\
\text { 및 임대 서비스업(N) }\end{array}$ & 608 & 574 & -5.6 & 165 & 160 & -3.0 & 642 & 632 & -1.6 \\
\hline $\begin{array}{c}\text { 예술, 스포츠 및 여가 } \\
\text { 관련 서비스업(R) }\end{array}$ & 118 & 107 & -8.7 & 117 & 102 & -12.9 & 23 & 21 & -11.2 \\
\hline
\end{tabular}

주: 비정규직 근로자 수는 복수 형태이기 때문에, 각각의 세부 비정규직 근로자 수의 합은 전체 비정규직 근로자 수와 상이함 자료: 고용노동부(2021). 2020년 8월 근로형태별 부가조사 결과

\section{3) 고용보험 가입률}

2020 년 8월 기준, 전체 근로자의 고용보험 가입률은 $72.6 \%$ 이고, 전년 대비 $1.7 \% \mathrm{p}$ 증가한 것으로 나타났다. 관광 관련 산업 중 숙박 및 음식점업과 예술, 스포츠 및 여가관 련 서비스업은 전체 대비 $20 \%$ 가량 고용보험 가입률이 낮은 특징을 보였다. 특히, 코 로나19 이전인 2019년과 비교해 보면 숙박 및 음식점업과 예술, 스포츠 및 여가관련 서비스업(각각 $2.8 \% \mathrm{p})$ 은 증가한 반면, 사업시설 관리, 사업 지원 및 임대 서비스업은 $-0.3 \% \mathrm{p}$ 감소한 것으로 나타났다.

〈표 4-8〉 고용보험 가입률

(단위: \%)

\begin{tabular}{c|c|c|c}
\hline 산업 & 2019년 8월(A) & 2020년 8월(B) & 증감(B-A) \\
\hline 전체 & 70.9 & 72.6 & 1.7 \\
\hline 숙박 및 음식점업(I) & 43.9 & 46.7 & 2.8 \\
\hline 사업시설 관리, 사업 지원 및 임대 서비스업(N) & 71.6 & 71.3 & -0.3 \\
\hline 예술, 스포츠 및 여가 관련 서비스업(R) & 52.3 & 55.0 & 2.8 \\
\hline
\end{tabular}

자료: 고용노동부(2021). 2020년 8월 근로형태별 부가조사 결과

종사상 지위별 고용보험 가입률은 전년 대비 모두 증가한 것으로 나타났다. 전반적으 로 상용근로자 대비 임시 및 일용근로자의 고용보험 가입률이 매우 낮은 것이 특징이다. 관광 관련 산업 중 숙박 및 음식점업은 임시근로자(26.3\%)와 일용근로자(0.6\%)의 고용 보험 가입률이 전체 대비 상대적으로 낮은 특징이 나타났다. 한편, 사업시설 관리, 사업 
지원 및 임대 서비스업은 상용근로자의 고용보험 가입률(86.6\%)이 전체 대비 낮은 특징 이 있고, 임시근로자(40.6\%)는 전체 대비 높으나, 전년 대비 감소폭(11.9\%p)이 큰 특징 을 보였다.

〈표 4-9〉 종사상 지위별 고용보험 가입률

(단위: \%)

\begin{tabular}{|c|c|c|c|c|}
\hline \multirow{2}{*}{ 산업 } & \multirow{2}{*}{ 종사상 지위 } & \multicolumn{2}{|c|}{ 고용보험 가입률(\%) } & \multirow{2}{*}{$\begin{array}{l}\text { 증감 } \\
(\mathrm{B}-\mathrm{A})\end{array}$} \\
\hline & & 2019년 8월(A) & 2020년 8월(B) & \\
\hline \multirow{3}{*}{ 전체 } & 상용근로자 & 93.5 & 93.8 & 0.4 \\
\hline & 임시근로자 & 30.1 & 30.5 & 0.4 \\
\hline & 일용근로자 & 5.5 & 5.7 & 0.3 \\
\hline \multirow{3}{*}{ 숙박 및 음식점업(I) } & 상용근로자 & 93.7 & 93.0 & -0.7 \\
\hline & 임시근로자 & 23.6 & 26.3 & 2.7 \\
\hline & 일용근로자 & 1.8 & 0.6 & -1.3 \\
\hline \multirow{3}{*}{$\begin{array}{l}\text { 사업시설 관리, 사업 지원 } \\
\text { 및 임대 서비스업(N) }\end{array}$} & 상용근로자 & 86.7 & 86.6 & -0.1 \\
\hline & 임시근로자 & 52.5 & 40.6 & -11.9 \\
\hline & 일용근로자 & 2.9 & 6.4 & 3.5 \\
\hline \multirow{3}{*}{$\begin{array}{l}\text { 예술, 스포츠 및 여가 } \\
\text { 관련 서비스업(R) }\end{array}$} & 상용근로자 & 93.7 & 90.5 & -3.1 \\
\hline & 임시근로자 & 31.6 & 30.4 & -1.2 \\
\hline & 일용근로자 & 5.4 & 5.7 & 0.3 \\
\hline
\end{tabular}

자료: 고용노동부(2021). 2020년 8월 근로형태별 부가조사 결과

코로나19 이후 고용시장 변화의 일반적 특성은 취업자 감소에 따른 노동력의 비경제 활동인구화, 취업 취약계층의 고용 악화, 업종별 고용편차 심화, 소규모 사업장의 고용 위기로 요약된다(윤정혜, 2021). 


\section{다. 고용보험통계 분석 결과11)}

\section{1) 산업별 사업장 현황}

고용보험통계 분석 결과, 전체 고용보험 가입 사업장 수는 코로나19 이전 대비 소폭 증가한 것으로 나타났다. 숙박 및 음식점업을 살펴보면, 코로나19 발생 전인 2020년 1 월 7.4\%의 증감률을 보인 반면, 2021년 5월의 경우 3.9\%의 증감률을 보였다. 2021년 3월을 기점으로 관광 관련 산업은 전체 산업 대비 낮은 증가율을 보이고 있다.

〈표 4-10〉산업별 사업장 현황

\begin{tabular}{c|c|c|c|c|c|c|c|c}
\hline \multirow{2}{*}{ 시점 } & \multicolumn{3}{|c|}{ 전체 } & \multicolumn{2}{c|}{ I. 숙박 및 음식점업 } & \multicolumn{2}{c|}{$\begin{array}{c}\text { N. 사업시설관리 및 } \\
\text { 사업지원 서비스업 }\end{array}$} & \multicolumn{2}{c}{$\begin{array}{c}\text { R. 예술 스포츠 및 } \\
\text { 여가관련 서비스업 }\end{array}$} \\
\cline { 2 - 10 } & $\begin{array}{c}\text { 사업장 수 } \\
\text { (개) }\end{array}$ & $\begin{array}{c}\text { 전년 대비 } \\
\text { 증감률(\%) }\end{array}$ & $\begin{array}{c}\text { 사업장 수 } \\
\text { (개) }\end{array}$ & $\begin{array}{c}\text { 전년 대비 } \\
\text { 증감률(\%) }\end{array}$ & $\begin{array}{c}\text { 사업장 수 } \\
\text { (개) }\end{array}$ & $\begin{array}{c}\text { 전년 대비 } \\
\text { 증감률(\%) }\end{array}$ & $\begin{array}{c}\text { 사업장 수 } \\
\text { (개) }\end{array}$ & $\begin{array}{c}\text { 전년 대비 } \\
\text { 증감률(\%) }\end{array}$ \\
\hline 2020.01 & $2,261,534$ & 0.3 & 299,406 & 7.4 & 61,248 & 4.3 & 32,033 & 9.4 \\
\hline 2020.02 & $2,230,355$ & 3.6 & 300,718 & 7.0 & 61,429 & 4.4 & 32,282 & 8.9 \\
\hline 2020.03 & $2,273,634$ & 3.6 & 302,628 & 6.5 & 61,996 & 4.3 & 32,632 & 8.3 \\
\hline 2020.04 & $2,306,868$ & 2.4 & 303,700 & 5.6 & 62,402 & 3.7 & 32,814 & 7.5 \\
\hline 2020.05 & $2,307,943$ & 1.9 & 304,109 & 5.2 & 62,714 & 3.6 & 32,920 & 6.8 \\
\hline 2020.06 & $2,325,016$ & 2.8 & 306,774 & 5.3 & 63,287 & 3.9 & 33,269 & 6.7 \\
\hline 2020.07 & $2,323,238$ & 2.5 & 309,629 & 5.9 & 63,648 & 4.1 & 33,622 & 7.3 \\
\hline 2020.08 & $2,328,367$ & 3.0 & 311,526 & 6.2 & 63,818 & 4.5 & 33,824 & 7.4 \\
\hline 2020.09 & $2,340,749$ & 6.2 & 312,605 & 7.2 & 64,071 & 5.4 & 33,898 & 8.1 \\
\hline 2020.10 & $2,355,414$ & 4.9 & 313,720 & 6.9 & 64,204 & 5.4 & 34,027 & 8.0 \\
\hline 2020.11 & $2,352,513$ & 2.5 & 311,560 & 5.4 & 63,810 & 4.3 & 33,762 & 6.3 \\
\hline 2020.12 & $2,395,603$ & 1.5 & 310,865 & 4.4 & 63,735 & 3.9 & 33,707 & 5.9 \\
\hline 2021.01 & $2,314,294$ & 2.3 & 312,316 & 4.3 & 63,837 & 4.2 & 33,821 & 5.6 \\
\hline 2021.02 & $2,337,704$ & 4.8 & 314,434 & 4.6 & 64,358 & 4.8 & 34,086 & 5.6 \\
\hline 2021.03 & $2,440,124$ & 7.3 & 317,237 & 4.8 & 65,046 & 4.9 & 34,464 & 5.6 \\
\hline 2021.04 & $2,477,028$ & 7.4 & 313,810 & 3.3 & 65,195 & 4.5 & 34,416 & 4.9 \\
\hline 2021.05 & $2,522,868$ & 9.3 & 316,074 & 3.9 & 65,712 & 4.8 & 34,758 & 5.6 \\
\hline
\end{tabular}

자료: 고용노동부·한국고용정보원(2020.1월 2021.5월). 고용보험통계표

11) 고용보험 통계자료는 한국표준산업분류에 따른 대분류 업종을 기준으로 관광 연관 산업을 추출하여 분석 한 자료로, 관광진흥법 상의 관광사업과 일치하지 않음 


\section{2) 산업별 피보험자 현황}

전체 산업의 고용보험 피보험자 수는 코로나19 이전인 2019년도와 비교하면 꾸준히 증가세를 유지하고 있다. 반면, 관광 관련 산업 중 숙박 및 음식점업과 예술 스포츠 및 여가관련 서비스업은 2020년 5월을 기점으로 꾸준히 감소세를 유지하고 있다.

〈표 4-11〉 산업별 피보험자 현황

\begin{tabular}{c|c|c|c|c|c|c|c|c}
\hline \multirow{2}{*}{ 시점 } & \multicolumn{3}{|c|}{ 전체 } & \multicolumn{2}{c|}{ I. 숙박 및 음식점업 } & \multicolumn{2}{c|}{$\begin{array}{c}\text { N. 사업시설관리 및 } \\
\text { 사업 지원 서비스업 }\end{array}$} & \multicolumn{2}{c}{$\begin{array}{c}\text { R. 예술 스포측 및 } \\
\text { 여가관련 서비스업 }\end{array}$} \\
\cline { 2 - 11 } & $\begin{array}{c}\text { 피보험자 } \\
\text { 수(명) }\end{array}$ & $\begin{array}{c}\text { 전년 대비 } \\
\text { 증감률(\%) }\end{array}$ & $\begin{array}{c}\text { 피보험자 } \\
\text { 수(명) }\end{array}$ & $\begin{array}{c}\text { 전년 대비 } \\
\text { 증감률(\%) }\end{array}$ & $\begin{array}{c}\text { 피보험자 } \\
\text { 수(명) }\end{array}$ & $\begin{array}{c}\text { 전년 대비 } \\
\text { 증감률(\%) }\end{array}$ & $\begin{array}{c}\text { 피보험자 } \\
\text { 수(명) }\end{array}$ & $\begin{array}{c}\text { 전년 대비 } \\
\text { 증감률(\%) }\end{array}$ \\
\hline 2020.01 & $13,707,119$ & 2.8 & 684,490 & 9.7 & $1,069,598$ & -0.6 & 148,680 & 5.6 \\
\hline 2020.02 & $13,823,936$ & 2.8 & 686,843 & 8.6 & $1,096,337$ & -0.9 & 149,962 & 5.3 \\
\hline 2020.03 & $13,782,154$ & 1.9 & 661,337 & 4.2 & $1,090,828$ & -1.6 & 147,845 & 3.1 \\
\hline 2020.04 & $13,801,162$ & 1.2 & 649,790 & 0.5 & $1,087,882$ & -2.3 & 147,733 & 0.6 \\
\hline 2020.05 & $13,847,933$ & 1.2 & 651,645 & -0.3 & $1,094,568$ & -2.3 & 148,869 & -0.2 \\
\hline 2020.06 & $13,899,138$ & 1.4 & 659,902 & -0.1 & $1,097,540$ & -1.5 & 149,642 & -0.4 \\
\hline 2020.07 & $13,936,612$ & 1.4 & 666,751 & -0.1 & $1,099,583$ & -1.4 & 151,340 & -1.1 \\
\hline 2020.08 & $14,048,509$ & 2.0 & 672,189 & -0.5 & $1,105,751$ & -1.6 & 152,476 & -2.0 \\
\hline 2020.09 & $14,157,571$ & 2.5 & 663,633 & -1.7 & $1,108,446$ & -1.2 & 151,727 & -0.7 \\
\hline 2020.10 & $14,261,703$ & 2.7 & 659,651 & -3.1 & $1,120,255$ & -0.4 & 151,693 & -1.2 \\
\hline 2020.11 & $14,329,709$ & 2.9 & 663,432 & -3.1 & $1,121,309$ & -0.4 & 151,443 & -1.5 \\
\hline 2020.12 & $14,111,690$ & 1.8 & 656,804 & -4.7 & $1,106,086$ & -1.2 & 147,817 & -2.0 \\
\hline 2021.01 & $13,885,859$ & 1.3 & 631,934 & -7.7 & $1,049,886$ & -1.8 & 139,885 & -5.9 \\
\hline 2021.02 & $14,025,756$ & 1.5 & 630,004 & -8.3 & $1,081,825$ & -1.3 & 141,035 & -6.0 \\
\hline 2021.03 & $14,116,137$ & 2.4 & 628,800 & -4.9 & $1,089,253$ & -0.1 & 143,840 & -2.7 \\
\hline 2021.04 & $14,232,249$ & 3.1 & 636,152 & -2.1 & $1,098,841$ & 1.0 & 147,038 & -0.5 \\
\hline 2021.05 & $14,299,710$ & 3.3 & 641,178 & -1.6 & $1,104,795$ & 0.9 & 148,913 & 0.0 \\
\hline
\end{tabular}

자료: 고용노동부·한국고용정보원(2020.1월 2021.5월). 고용보험통계표

[그림 4-4] 전년 대비 피보험자 증감률(\%)

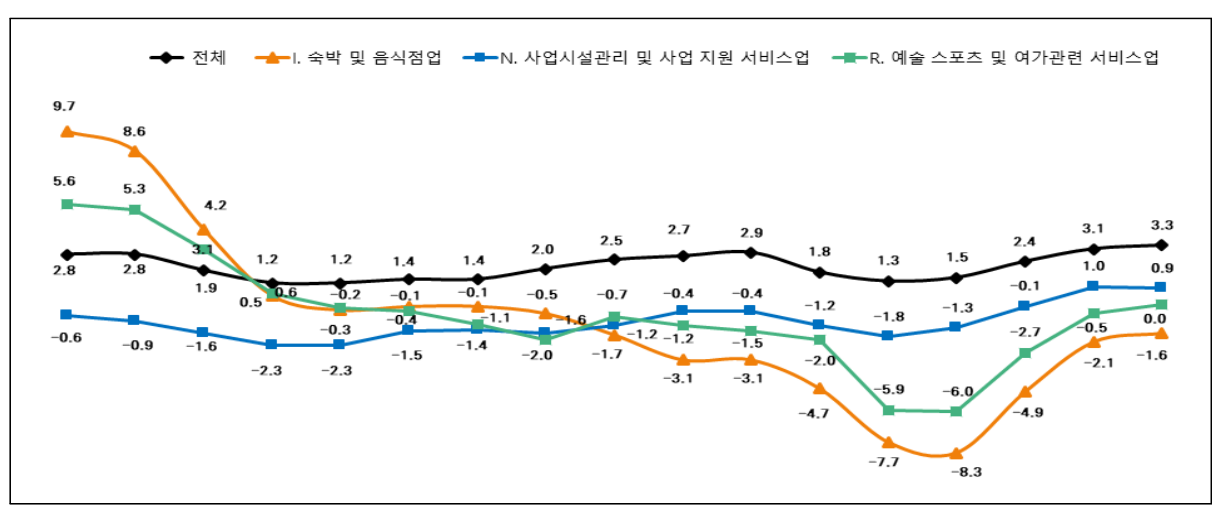




\section{3) 산업별 피보험자 상실 현황}

전체 산업의 고용보험 피보험자 상실자 수는 코로나19 대유행 시기마다 감소한 것으 로 분석된다. 관광 관련 산업도 유사한 시기에 고용보험 피보험자 상실자 수가 전년 대 비 증가하였고, 특히, 숙박 및 음식점업과 예술 스포츠 및 여가관련 서비스업의 경우 2020년 2월이 타 시기에 비해 상대적으로 높은 특징이 나타났다.

〈표 4-12〉 산업별 피보험 상실자 현황

(단위: 명, \%)

\begin{tabular}{c|c|c|c|c|c|c|c|c}
\hline \multirow{2}{*}{ 시점 } & \multicolumn{2}{|c|}{ 전체 } & \multicolumn{2}{c|}{ I. 숙박 및 음식점업 } & \multicolumn{2}{c|}{$\begin{array}{c}\text { N. 사업시설관리 및 } \\
\text { 사업지원 서비스업 }\end{array}$} & \multicolumn{2}{c}{$\begin{array}{c}\text { R. 예술 스포츠 및 } \\
\text { 여가관련 서비스업 }\end{array}$} \\
\cline { 2 - 10 } & 상실자 수 & $\begin{array}{c}\text { 전년 대비 } \\
\text { 증감률 }\end{array}$ & 상실자 수 & $\begin{array}{c}\text { 전년 대비 } \\
\text { 증감률 }\end{array}$ & 상실자 수 & $\begin{array}{c}\text { 전년 대비 } \\
\text { 증감률 }\end{array}$ & 상실자 수 & $\begin{array}{c}\text { 전년 대비 } \\
\text { 증감률 }\end{array}$ \\
\hline 2020.01 & 875,330 & -3.1 & 65,846 & 7.4 & 140,621 & -9.1 & 14,173 & 1.3 \\
\hline 2020.02 & 561,034 & 22.4 & 66,310 & 38.2 & 60,642 & 8.5 & 8,312 & 25.0 \\
\hline 2020.03 & 726,330 & 3.4 & 74,130 & 28.0 & 68,981 & -3.0 & 11,014 & 8.7 \\
\hline 2020.04 & 529,994 & -4.4 & 57,269 & 3.4 & 60,959 & -7.2 & 6,570 & -4.9 \\
\hline 2020.05 & 434,672 & -15.4 & 40,460 & -17.1 & 46,026 & -21.4 & 4,660 & -24.4 \\
\hline 2020.06 & 462,367 & -8.0 & 46,947 & -9.7 & 47,672 & -9.3 & 5,431 & -11.7 \\
\hline 2020.07 & 570,791 & -6.9 & 52,086 & -13.5 & 61,056 & -4.4 & 7,045 & -11.9 \\
\hline 2020.08 & 480,690 & -6.1 & 49,993 & -17.8 & 48,892 & -11.2 & 6,094 & -17.2 \\
\hline 2020.09 & 533,878 & 8.6 & 59,376 & 3.0 & 53,748 & 0.7 & 7,069 & -28.1 \\
\hline 2020.10 & 464,555 & -6.9 & 50,044 & -13.2 & 48,093 & -6.2 & 5,334 & -21.6 \\
\hline 2020.11 & 482,069 & -6.3 & 45,613 & -18.7 & 51,310 & -3.8 & 6,010 & -15.2 \\
\hline 2020.12 & 756,842 & 40.3 & 56,792 & 11.6 & 64,264 & 12.1 & 9,560 & 3.1 \\
\hline 2021.01 & 977,176 & 11.6 & 66,391 & 0.8 & 151,868 & 8.0 & 15,926 & 12.4 \\
\hline 2021.02 & 469,995 & -16.2 & 43,229 & -34.8 & 51,326 & -15.4 & 5,750 & -30.8 \\
\hline 2021.03 & 698,522 & -3.8 & 50,716 & -31.6 & 60,967 & -11.6 & 6,919 & -37.2 \\
\hline 2021.04 & 560,020 & 5.7 & 49,800 & -13.0 & 63,404 & 4.0 & 5,851 & -10.9 \\
\hline 2021.05 & 502,030 & 15.5 & 43,478 & 7.5 & 51,174 & 11.2 & 5,292 & 13.6 \\
\hline
\end{tabular}

자료: 고용노동부·한국고용정보원(2020.1월 2021.5월). 고용보험통계표 
[그림 4-5] 전년 대비 피보험 상실자 증감률(\%)

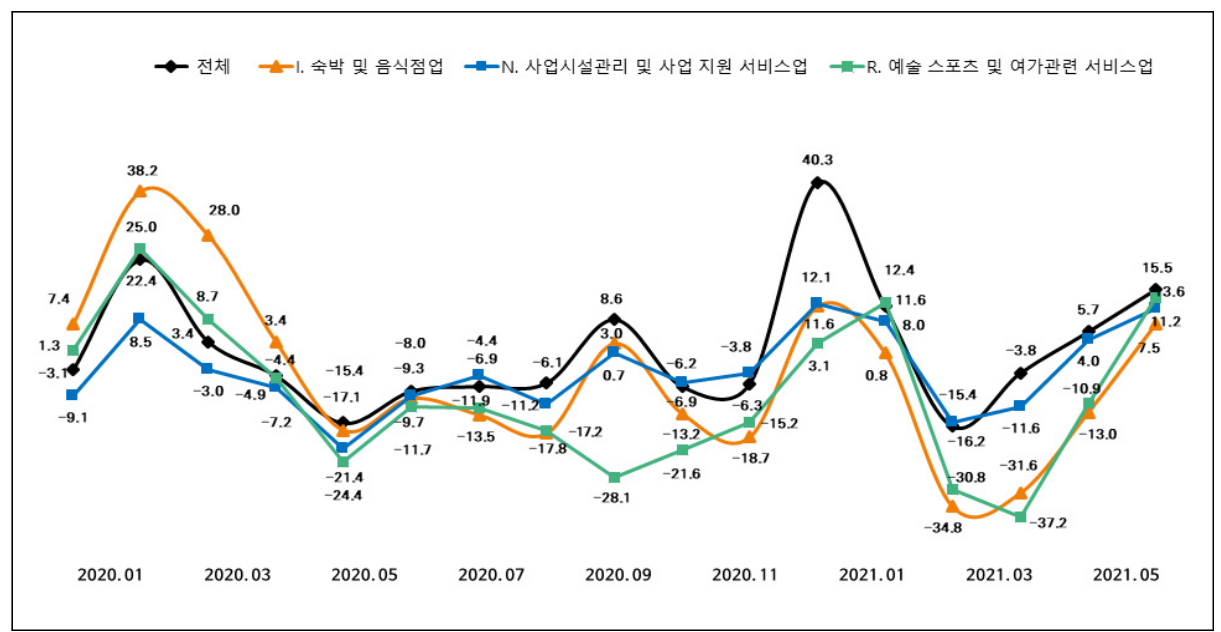

주: 1차 대유행(2020년 2-3월), 2차 대유행(2020년 9월), 3차 대유행(2020년 12월)

\section{4) 산업별 실업급여 수급자격인정자 현황}

전체 산업의 실업급여 피보험 수급자격인정자는 2020년 1월부터 2021년 2월까지 약 1 년간 지속적으로 전년 대비 증가한 수치를 보였다. 특히, 관광 관련 산업은 전년 대비 증가율이 전체 산업 대비 전반적으로 높은 수준을 보이고 있으며, 숙박 및 음식점업의 경우, 코로나19 대유행 시기인 2020년 3월, 4월, 9월과 2021년 1월에 크게 증가한 것 으로 나타났다.

〈표 4-13〉 산업별 피보험 수급자격인정자 현황

\begin{tabular}{c|c|c|c|c|c|c|c|c}
\hline \multirow{2}{*}{ 시점 } & \multicolumn{2}{|c|}{ 전체 } & \multicolumn{2}{|c|}{ I. 숙박 및 음식점업 } & \multicolumn{2}{c|}{$\begin{array}{c}\text { N. 사업시설관리 및 } \\
\text { 사업지원 서비스업 }\end{array}$} & \multicolumn{2}{|c|}{$\begin{array}{c}\text { R. 예술 스포츠 및 } \\
\text { 여가관련 서비스업 }\end{array}$} \\
\cline { 2 - 10 } & $\begin{array}{c}\text { 인정자 수 } \\
\text { (명) }\end{array}$ & $\begin{array}{l}\text { 전년 대비 } \\
\text { 증감률(\%) }\end{array}$ & $\begin{array}{c}\text { 인정자 수 } \\
\text { (명) }\end{array}$ & $\begin{array}{c}\text { 전년 대비 } \\
\text { 증감률(\%) }\end{array}$ & $\begin{array}{c}\text { 인정자 수 } \\
\text { (명) }\end{array}$ & $\begin{array}{c}\text { 전년 대비 } \\
\text { 증감률(\%) }\end{array}$ & $\begin{array}{c}\text { 인정자 수 } \\
\text { (명) }\end{array}$ & $\begin{array}{c}\text { 전년 대비 } \\
\text { 증감률(\%) }\end{array}$ \\
\hline 2020.01 & 173,580 & 1.8 & 7,803 & 0.5 & 24,237 & 2.0 & 3,551 & 8.8 \\
\hline 2020.02 & 107,042 & 33.6 & 7,546 & 46.2 & 12,439 & 43.9 & 1,504 & 46.3 \\
\hline 2020.03 & 155,298 & 24.6 & 13,668 & 123.0 & 14,376 & 39.7 & 1,961 & 72.8 \\
\hline 2020.04 & 128,578 & 32.8 & 12,669 & 101.1 & 15,700 & 46.0 & 1,548 & 51.5 \\
\hline 2020.05 & 110,025 & 31.1 & 9,183 & 62.6 & 11,826 & 35.5 & 1,235 & 46.7 \\
\hline 2020.06 & 105,002 & 39.5 & 8,238 & 50.7 & 10,505 & 38.8 & 1,131 & 62.5 \\
\hline 2020.07 & 113,644 & 13.0 & 8,471 & 22.3 & 11,931 & 9.7 & 1,607 & 25.2 \\
\hline 2020.08 & 90,004 & 15.7 & 7,303 & 24.2 & 9,202 & 15.5 & 1,092 & 36.0 \\
\hline
\end{tabular}




\begin{tabular}{c|c|c|c|c|c|c|c|c}
\hline \multirow{2}{*}{ 시점 } & \multicolumn{3}{|c|}{ 전체 } & \multicolumn{2}{c|}{ I. 숙박 및 음식점업 } & \multicolumn{2}{c|}{$\begin{array}{c}\text { N. 사업시설관리 및 } \\
\text { 사업지원 서비스업 }\end{array}$} & \multicolumn{2}{|c}{$\begin{array}{c}\text { R. 예술 스포츠 및 } \\
\text { 여가관련 서비스업 }\end{array}$} \\
\cline { 2 - 10 } & $\begin{array}{c}\text { 인정자 수 } \\
\text { (명) }\end{array}$ & $\begin{array}{c}\text { 전년 대비 } \\
\text { 증감률(\%) }\end{array}$ & $\begin{array}{c}\text { 인정자 수 } \\
\text { (명) }\end{array}$ & $\begin{array}{l}\text { 전년 대비 } \\
\text { 증감률(\%) }\end{array}$ & $\begin{array}{c}\text { 인정자 수 } \\
\text { (명) }\end{array}$ & $\begin{array}{c}\text { 전년 대비 } \\
\text { 증감률(\%) }\end{array}$ & $\begin{array}{c}\text { 인정자 수 } \\
\text { (명) }\end{array}$ & $\begin{array}{c}\text { 전년 대비 } \\
\text { 증감률(\%) }\end{array}$ \\
\hline 2020.09 & 98,026 & 39.1 & 10,103 & 92.2 & 9,103 & 31.3 & 1,257 & 50.0 \\
\hline 2020.10 & 87,560 & 6.0 & 8,658 & 34.0 & 9,167 & 6.6 & 1,098 & 12.7 \\
\hline 2020.11 & 89,463 & 3.8 & 7,785 & 26.0 & 9,093 & 7.4 & 1,370 & 13.3 \\
\hline 2020.12 & 107,325 & 12.7 & 9,336 & 50.1 & 11,369 & 19.9 & 2,571 & 6.9 \\
\hline 2021.01 & 210,671 & 21.4 & 15,069 & 93.1 & 28,383 & 17.1 & 4,493 & 26.5 \\
\hline 2021.02 & 108,745 & 1.6 & 9,352 & 23.9 & 11,687 & -6.0 & 1,585 & 5.4 \\
\hline 2021.03 & 148,035 & -4.7 & 9,178 & -32.9 & 11,508 & -19.9 & 1,346 & -31.4 \\
\hline 2021.04 & 102,836 & -20.0 & 7,979 & -37.0 & 12,194 & -22.3 & 982 & -36.6 \\
\hline 2021.05 & 85,968 & -21.9 & 6,838 & -25.5 & 8,486 & -28.2 & 846 & -31.5 \\
\hline
\end{tabular}

자료: 고용노동부·한국고용정보원(2020.1월 2021.5월). 고용보험통계표

[그림 4-6] 전년 대비 실업급여 수급자격인정자 증감률(\%)

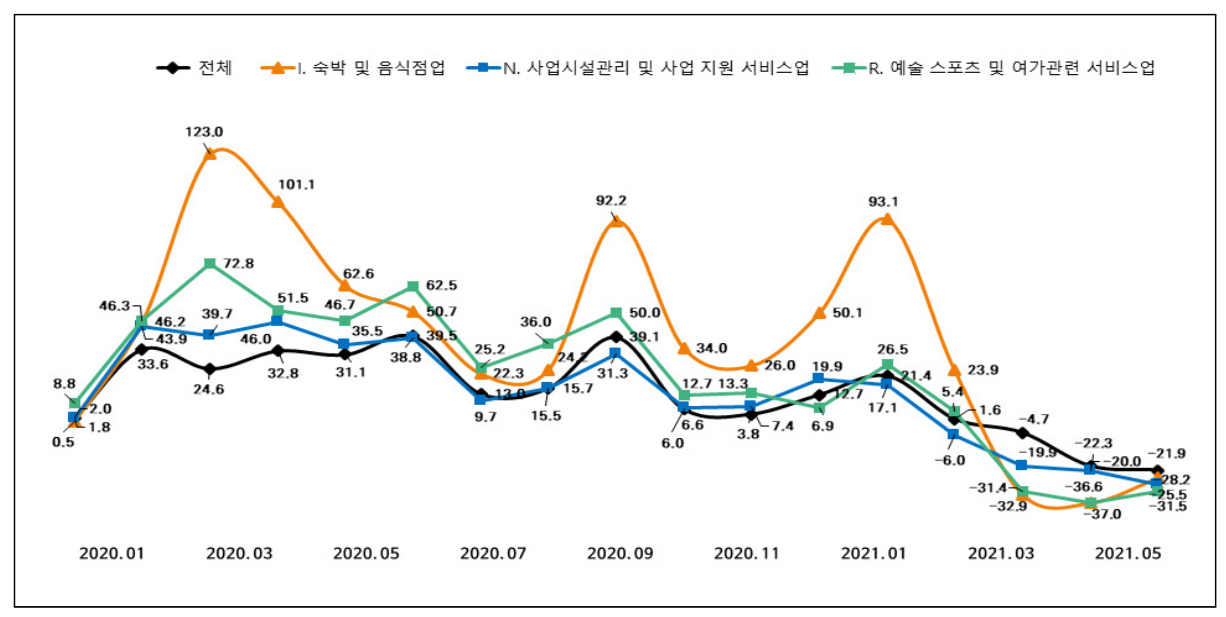

\section{5) 산업별 실업급여 지급 현황}

전체 산업의 실업급여 지급자 수는 전년 대비 증가한 수치가 지속되고 있고, 특히, 2020년 9월에 전년 대비 $56.4 \%$ 증가하여, 고용상 가장 타격이 컸던 것으로 예상된다. 관광 관련 산업 중 숙박 및 음식점업의 실업급여 지급자 수가 전년 대비 높아, 타격이 가장 컸던 것으로 분석되고, 특히, 2020년 5월부터 2021년 2월까지 70\% 이상을 상회 하며 지속적으로 타격을 받은 것으로 분석된다. 
〈표 4-14〉 산업별 실업급여 지급인원 현황

\begin{tabular}{c|c|c|c|c|c|c|c|c}
\hline \multirow{2}{*}{ 시점 } & \multicolumn{2}{|c|}{ 전체 } & \multicolumn{2}{c|}{ I. 숙박 및 음식점업 } & \multicolumn{2}{c|}{$\begin{array}{c}\text { N. 사업시설관리 및 } \\
\text { 사업지원 서비스업 }\end{array}$} & \multicolumn{2}{c}{$\begin{array}{c}\text { R. 예술 스포츠 및 } \\
\text { 여가관련 서비스업 }\end{array}$} \\
\cline { 2 - 10 } & $\begin{array}{c}\text { 지급 인원 } \\
\text { (명) }\end{array}$ & $\begin{array}{c}\text { 전년 대비 } \\
\text { 증감률(\%) }\end{array}$ & $\begin{array}{c}\text { 지급 인원 } \\
\text { (명) }\end{array}$ & $\begin{array}{c}\text { 전년 대비 } \\
\text { 증감률(\%) }\end{array}$ & $\begin{array}{c}\text { 지급 인원 } \\
\text { (명) }\end{array}$ & $\begin{array}{c}\text { 전년 대비 } \\
\text { 증감률(\%) }\end{array}$ & $\begin{array}{c}\text { 지급 인원 } \\
\text { (명) }\end{array}$ & $\begin{array}{c}\text { 전년 대비 } \\
\text { 증감률(\%) }\end{array}$ \\
\hline 2020.01 & 506,781 & 6.9 & 31,806 & 16.1 & 55,317 & 3.4 & 8,190 & 9.6 \\
\hline 2020.02 & 543,468 & 16.2 & 32,695 & 24.7 & 62,589 & 14.9 & 9,113 & 19.9 \\
\hline 2020.03 & 618,346 & 20.1 & 40,205 & 43.9 & 68,871 & 21.3 & 10,041 & 30.8 \\
\hline 2020.04 & 660,732 & 24.7 & 48,500 & 65.7 & 74,432 & 28.1 & 9,869 & 49.9 \\
\hline 2020.05 & 686,335 & 33.9 & 52,965 & 81.9 & 79,053 & 39.8 & 9,425 & 68.6 \\
\hline 2020.06 & 719,175 & 45.7 & 56,424 & 99.5 & 82,589 & 54.8 & 9,106 & 83.4 \\
\hline 2020.07 & 739,147 & 45.5 & 58,293 & 92.2 & 84,409 & 56.3 & 9,129 & 81.0 \\
\hline 2020.08 & 711,684 & 48.2 & 56,555 & 89.9 & 79,550 & 56.1 & 8,482 & 82.0 \\
\hline 2020.09 & 705,122 & 56.4 & 57,821 & 99.3 & 76,951 & 65.5 & 8,226 & 87.3 \\
\hline 2020.10 & 649,582 & 49.1 & 54,659 & 83.6 & 69,045 & 52.4 & 7,591 & 70.1 \\
\hline 2020.11 & 612,343 & 46.2 & 53,068 & 81.8 & 64,577 & 49.2 & 7,383 & 63.7 \\
\hline 2020.12 & 606,524 & 42.5 & 52,653 & 76.8 & 63,709 & 44.6 & 8,353 & 48.4 \\
\hline 2021.01 & 677,096 & 33.6 & 56,928 & 79.0 & 73,444 & 32.8 & 11,215 & 36.9 \\
\hline 2021.02 & 707,453 & 30.2 & 59,102 & 80.8 & 79,814 & 27.5 & 12,124 & 33.0 \\
\hline 2021.03 & 771,488 & 24.8 & 61,978 & 54.2 & 83,471 & 21.2 & 12,320 & 22.7 \\
\hline 2021.04 & 748,537 & 13.3 & 59,676 & 23.0 & 81,593 & 9.6 & 10,637 & 7.8 \\
\hline 2021.05 & 712,595 & 3.8 & 57,023 & 7.7 & 78,813 & -0.3 & 9,321 & -1.1 \\
\hline
\end{tabular}

자료: 고용노동부·한국고용정보원(2020.1월 2021.5월). 고용보험통계표

[그림 4-7] 전년 대비 실업급여 지급인원 증감률(\%)

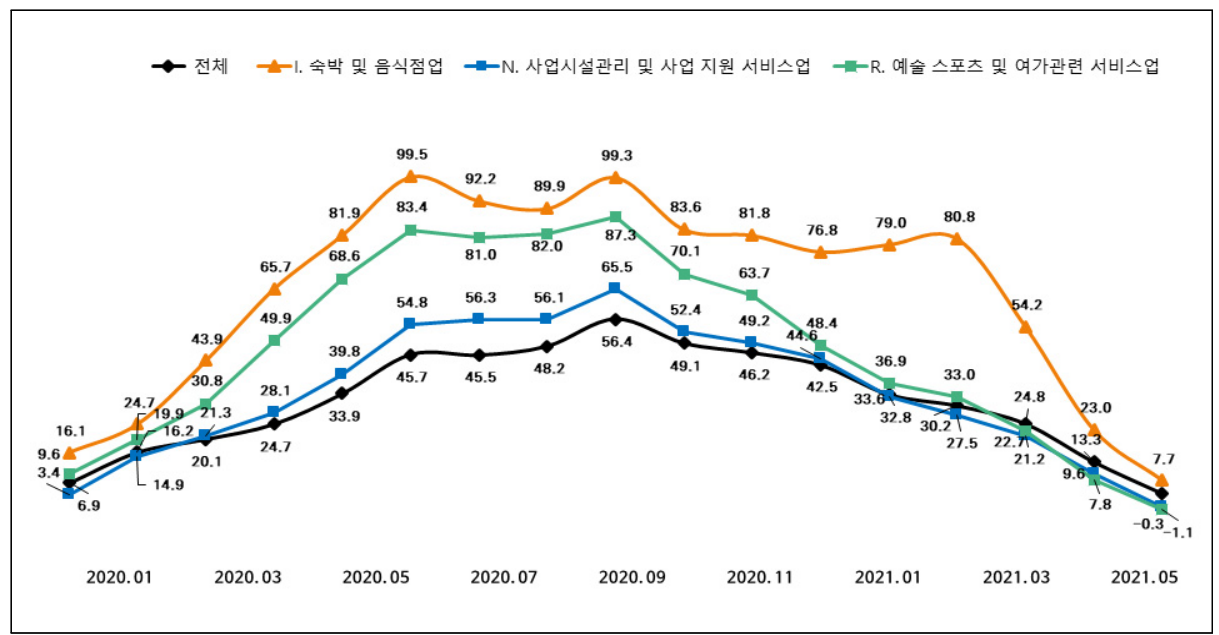




\section{6) 산업별 고용안정사업 지원 현황}

고용안정사업 지원 건수는 전반적으로 전년 대비 증가한 것으로 분석되었고, 특히 2020년 5월을 기점으로 지원 건수가 전년 대비 증가폭이 높으며, 3차 대유행 시기인 2020년 12월 전년 대비 크게 증가한 특징이 나타났다. 특히, 관광 관련 산업은 전체 산업 대비 증가율이 매우 높고, 숙박 및 음식점업과 예술 스포츠 및 여가관련 서비스업 은 2020년 12월에 전년 대비 크게 증가한 특징을 보였다.

〈표 4-15〉 산업별 고용안정사업 지원 현황

\begin{tabular}{|c|c|c|c|c|c|c|c|c|}
\hline \multirow{2}{*}{ 시점 } & \multicolumn{2}{|c|}{ 전체 } & \multicolumn{2}{|c|}{ I. 숙박 및 음식점업 } & \multicolumn{2}{|c|}{$\begin{array}{l}\text { N. 사업시설관리 및 } \\
\text { 사업지원 서비스업 }\end{array}$} & \multicolumn{2}{|c|}{$\begin{array}{l}\text { R. 예술 스포츠 및 } \\
\text { 여가관련 서비스업 }\end{array}$} \\
\hline & 건수(개) & $\begin{array}{l}\text { 전년 대비 } \\
\text { 증감률(\%) }\end{array}$ & 건수(개) & $\begin{array}{l}\text { 전년 대비 } \\
\text { 증감률(\%) }\end{array}$ & 건수(개) & $\begin{array}{l}\text { 전년 대비 } \\
\text { 증감률(\%) }\end{array}$ & 건수(개) & $\begin{array}{l}\text { 전년 대비 } \\
\text { 증감률(\%) }\end{array}$ \\
\hline 2020.01 & 62,040 & 0.4 & 1,215 & 15.2 & 1,709 & -5.4 & 380 & 7.0 \\
\hline 2020.02 & 40,658 & -3.9 & 684 & -8.1 & 1,120 & -4.4 & 241 & 3.9 \\
\hline 2020.03 & 48,746 & -6.0 & 770 & -24.0 & 1,384 & -2.7 & 300 & -9.4 \\
\hline 2020.04 & 56,355 & -3.3 & 1,855 & 95.3 & 3,417 & 116.4 & 698 & 75.8 \\
\hline 2020.05 & 83,142 & 50.1 & 4,827 & 365.5 & 6,059 & 336.5 & 1,606 & 328.3 \\
\hline 2020.06 & 93,055 & 98.9 & 5,361 & 474.0 & 6,315 & 393.0 & 1,670 & 525.5 \\
\hline 2020.07 & 88,997 & 71.2 & 4,733 & 336.6 & 6,243 & 336.3 & 1,511 & 367.8 \\
\hline 2020.08 & 87,468 & 97.3 & 3,968 & 356.6 & 6,083 & 376.4 & 1,372 & 451.0 \\
\hline 2020.09 & 91,560 & 95.9 & 4,013 & 419.8 & 6,353 & 356.1 & 1,421 & 393.4 \\
\hline 2020.10 & 76,785 & 62.6 & 3,481 & 433.1 & 5,492 & 312.3 & 1,353 & 414.4 \\
\hline 2020.11 & 78,647 & 66.3 & 3,880 & 445.7 & 5,536 & 318.4 & 1,359 & 538.0 \\
\hline 2020.12 & 78,081 & 270.6 & 3,825 & 1192.2 & 4,310 & 471.6 & 1,241 & 1038.5 \\
\hline 2021.01 & 105,360 & 69.8 & 3,977 & 227.3 & 3,570 & 108.9 & 1,430 & 276.3 \\
\hline 2021.02 & 67,038 & 64.9 & 3,706 & 441.8 & 3,450 & 208.0 & 1,429 & 492.9 \\
\hline 2021.03 & 95,815 & 96.6 & 5,531 & 618.3 & 4,961 & 258.5 & 1,786 & 495.3 \\
\hline 2021.04 & 91,728 & 62.8 & 4,618 & 148.9 & 4,658 & 36.3 & 1,356 & 94.3 \\
\hline 2021.05 & 82,066 & -1.3 & 3,880 & -19.6 & 4,316 & -28.8 & 1,251 & -22.1 \\
\hline
\end{tabular}

자료: 고용노동부·한국고용정보원(2020.1월 2021.5월). 고용보험통계표 


\section{7) 산업별 직업능력개발사업 지원 현황}

직원능력개발사업 지원 건수는 2020년 1월, 4-5월, 10 월을 제외하고는 전년 대비 증가한 것으로 나타났다. 특히, 관광 관련 산업 중 숙박 및 음식점업의 경우 2020년 2월 에 크게 증가하였고, 2021년 4월과 5월에는 전년 대비 2배 이상 증가한 특징을 보였다.

〈표 4-16〉 산업별 직업능력개발사업 지원 현황

\begin{tabular}{|c|c|c|c|c|c|c|c|c|}
\hline \multirow{2}{*}{ 시점 } & \multicolumn{2}{|c|}{ 전체 } & \multicolumn{2}{|c|}{ I. 숙박 및 음식점업 } & \multicolumn{2}{|c|}{$\begin{array}{l}\text { N. 사업시설관리 및 } \\
\text { 사업지원 서비스업 }\end{array}$} & \multicolumn{2}{|c|}{$\begin{array}{l}\text { R. 예술 스포츠 및 } \\
\text { 여가관련 서비스업 }\end{array}$} \\
\hline & 건수(개) & $\begin{array}{l}\text { 전년 대비 } \\
\text { 증감률(\%) }\end{array}$ & 건수(개) & $\begin{array}{l}\text { 전년 대비 } \\
\text { 증감률(\%) }\end{array}$ & 건수(개) & \begin{tabular}{|l|} 
전년 대비 \\
증감률(\%) \\
\end{tabular} & 건수(개) & $\begin{array}{l}\text { 전년 대비 } \\
\text { 증감률(\%) } \\
\end{array}$ \\
\hline 2020.01 & 121,493 & -25.8 & 242 & -41.1 & 1,301 & -68.6 & 38 & -19.1 \\
\hline 2020.02 & 117,005 & 33.9 & 471 & 93.0 & 2,246 & -33.6 & 80 & 95.1 \\
\hline 2020.03 & 115,921 & 11.3 & 338 & 0.6 & 1,947 & 37.2 & 58 & 18.4 \\
\hline 2020.04 & 90,511 & -8.6 & 172 & -46.3 & 1,292 & 12.9 & 30 & -45.5 \\
\hline 2020.05 & 92,434 & -18.7 & 181 & -46.4 & 1,535 & 31.6 & 32 & 10.3 \\
\hline 2020.06 & 120,308 & 17.8 & 193 & -41.0 & 1,164 & -30.0 & 31 & 0.0 \\
\hline 2020.07 & 142,314 & 8.9 & 287 & -12.8 & 1,674 & -52.0 & 50 & 13.6 \\
\hline 2020.08 & 110,573 & 20.0 & 240 & -24.5 & 2,197 & -16.3 & 28 & -73.1 \\
\hline 2020.09 & 138,118 & 15.8 & 514 & 66.9 & 1,838 & 10.9 & 54 & 31.7 \\
\hline 2020.10 & 103,299 & -19.4 & 328 & -16.8 & 1,455 & -64.0 & 28 & -24.3 \\
\hline 2020.11 & 142,542 & 22.2 & 441 & 33.6 & 2,074 & 11.1 & 56 & 33.3 \\
\hline 2020.12 & 152,544 & 38.9 & 481 & 43.2 & 1,959 & -31.2 & 132 & 106.3 \\
\hline 2021.01 & 132,662 & 9.2 & 456 & 88.4 & 2,024 & 55.6 & 72 & 89.5 \\
\hline 2021.02 & 123,977 & 6.0 & 287 & -39.1 & 1,604 & -28.6 & 45 & -43.8 \\
\hline 2021.03 & 155,866 & 34.5 & 496 & 46.7 & 2,253 & 15.7 & 81 & 39.7 \\
\hline 2021.04 & 132,706 & 46.6 & 420 & 144.2 & 1,849 & 43.1 & 19 & -36.7 \\
\hline 2021.05 & 147,031 & 59.1 & 492 & 171.8 & 1,157 & -24.6 & 37 & 15.6 \\
\hline
\end{tabular}

자료: 고용노동부·한국고용정보원(2020.1월 2021.5월). 고용보험통계표 


\section{제2절 관광산업 고용안전망 실태 분석}

\section{1. 고용유지지원금 수급 현황}

고용유지지원금은 경영이 일시적으로 어려워져 고용위기를 겪고 있는 사업주가 휴업, 휴직을 실시하고 휴업수당을 지급한 경우 근로자에게 지급한 인건비를 지원해주는 제도 이다. 고용유지지원금은 사업주가 해고가 아닌 휴업 또는 휴직으로 대응하여 대량 실업 을 막기 위한 것으로, 피보험자의 고용 안정을 보장하는 역할을 담당한다.

2020년은 코로나19의 영향으로 고용유지지원금 신청이 급증(계획신고 건 수 약 50 만건, 2019년 8,101건)하였고, 사업장 7만 2천 개소, 근로자 77만 여명(연인원 228만) 에 대해 2조 2,779 억 원을 지원하며 사상 최대를 기록하였다(고용노동부 보도자료, 2021.9.15.).

관광산업은 코로나19 발생 이후 특별고용지원업종으로 지정되어(2020.3.16.), 고용 유지지원금 확대, 지원기간 연장 등을 적용받고 있다. 정부는 코로나19의 영향이 장기화 되면서 2021년에는 여행업, 관광숙박업 등 특별고용지원업종의 지정기간을 2022년 3 월 31 일까지 1년간 연장하고, 유원시설업과 외국인 전용 카지노 등을 추가로 지정했다 (〈표 4-17〉 참고) 12 ).

특별고용지원업종 지정은 고용정책심의회의 심의·의결 과정을 통해 결정된다. 당초 2021년 3월 31일 종료 예정이던 여행업, 관광숙박업, 관광운송업, 공연업, 항공기취 급업, 면세점, 전시·국제회의업, 공항버스 등 8개 업종의 지정기간 연장은 코로나19 장기화로 인해 여행과 관광이 사실상 중단된 상황이 지속됨에 따라 관련 업종의 영업 및 고용상황이 여전히 심각하다는 점이 반영되었다. 특별고용지원업종 대부분에서

12) 정부는 특별고용지원 업종에 대한 유급고용유지지원금 지원기간 추가 지원을 의결하여, 항공업·여행업 등 특별고용지원 업종 사업장들은 기존 지원 일수(270일)에 30일을 추가하여 2021년에 최대 300일간 유급 휴업·휴직 지원을 받을 수 있게 됨(고용노동부 보도자료, 2021.9.16.) 
2020년 매출액이 전년 대비 60\% 80\% 감소한 것으로 나타났다(고용노동부 보도자료, 2021.3.17.).

〈표 4-17〉 2021년 기준 특별고용지원업종 지정 현황

\begin{tabular}{|c|c|c|}
\hline 구분 & 내용 & 비고 \\
\hline 여행업 & $\begin{array}{l}\text { 표준산업분류상 여행사 및 기타 여행보조 서비스업 또는「관광진흥법」제3조제1항 } \\
\text { 제1호의 여행업이면서 해당 자치단체에 등록한 업체 }\end{array}$ & \multirow{8}{*}{$\begin{array}{l}\text { 기간 } \\
\text { 연장 }\end{array}$} \\
\hline 관광숙박업 & $\begin{array}{l}\text { 표준산업분류상 호텔업·휴양콘도 운영업 또는「관광진흥법」제3조제1항제2호의 관 } \\
\text { 광숙박업이면서 해당 자치단체에 등록한 업체 }\end{array}$ & \\
\hline 관광운송업 & $\begin{array}{l}\text { 표준산업분류상 전세버스 운송업·외항 여객 운송업·내항 여객 운송업·내륙수상여객 } \\
\text { 및 화물 운송업·항만내 여객 운송업·항공 여객 운송업 또는 「여객자동차 운수사업법 } \\
\text { 등 관련법에 따라 해당 자치단체 또는 관할 관청에 등록 또는 승인받은 업체 }\end{array}$ & \\
\hline 공연업 & $\begin{array}{l}\text { 표준산업분류상 창작 및 예술 관련 서비스업 또는 「공연법」제9조제1항에 따라 공 } \\
\text { 연장 소재지 자치단체에 등록한 업체 중 국가 또는 지방자치단체가 아닌 업체 }\end{array}$ & \\
\hline 항공기취급업 & $\begin{array}{l}\text { 표준산업분류상 기타 항공 운송지원 서비스업 또는 「항공사업법」제44조제1항에 따 } \\
\text { 라 국토교통부장관에게 항공기취급업을 등록한 업체 }\end{array}$ & \\
\hline 면세점 & $\begin{array}{l}\text { 표준산업분류상 면세점 또는 「관세법」 제174조, 제176조의2 및 제196조에 따라 } \\
\text { 세관장으로부터 보세판매장 특허를 받은 업체 및 전체 매출액 중 위 보세판매장 특허 } \\
\text { 를 받은 업체와 관련된 매출액이 } 50 \% \text { 이상인 업체 }\end{array}$ & \\
\hline 전시국제회의업 & $\begin{array}{l}\text { 표준산업분류상 전시, 컨벤션 및 행사 대행업 또는「전시산업발전법」제2조에 따른 } \\
\text { 전시사업자로서 산업통상자원부 장관의 확인을 받은 업체 및「관광진흥법」제3조제 } \\
1 \text { 항제4호의 국제회의업이면서 해당 자치단체에 등록한 업체 }\end{array}$ & \\
\hline 공항버스 & $\begin{array}{l}\text { 여객자동차운송사업 면허를 받은 업체 중 운행노선에 공항을 포함하고 있으며, 매출 } \\
\text { 액 } 50 \% \text { 이상이 공항노선과 관련된 업체 }\end{array}$ & \\
\hline 영화업 & $\begin{array}{l}\text { 표준산업분류상 영화 관련 업종 또는 「영화 및 비디오물의 진흥에 관한 법률」제2조 } \\
\text { 제9호·제10호에 따른 영화제작·배급업, 영화상영관으로 자치단체에 등록한 업체 }\end{array}$ & \multirow{6}{*}{$\begin{array}{l}\text { 추가 } \\
\text { 지정 }\end{array}$} \\
\hline 노선버스 & $\begin{array}{l}\text { 시외버스(고속버스 포함), 시내버스(마을버스·농어촌버스 포함, 준공영제 대상업체 } \\
\text { 제외) }\end{array}$ & \\
\hline 항공기부품제조 & 표준산업분류상 항공기용 엔진 및 부품제조업 & \\
\hline 유원시설 & $\begin{array}{l}\text { 표준산업분류상 유원지 및 테마파크 운영업 또는 「관광진흥법」제3조제1항제6호에 } \\
\text { 따른 유원시설업으로 해당 자치단체가 허가한 업체이거나 신고·수리한 업체 }\end{array}$ & \\
\hline $\begin{array}{l}\text { 외국인전용 } \\
\text { 카지노 }\end{array}$ & $\begin{array}{l}\text { 「관광진흥법」에 따른 카지노업으로 문화부장관이 허가한 외국인 전용 카지노이거나 } \\
\text { 「제주특별자치도 설치 및 국제자유도시 조성을 위한 특별법」에 따라 제주특별자치도 } \\
\text { 지사가 허가한 외국인 전용 카지노 }\end{array}$ & \\
\hline 수련시설 & $\begin{array}{l}\text { 표준산업분류상 청소년 수련시설 운영업 또는「청소년활동진흥법」제10조에 따른 } \\
\text { 청소년 수련시설로 해당 자치단체에 등록한 업체 }\end{array}$ & \\
\hline
\end{tabular}

자료: 고용노동부 보도자료(2021.3.17.). 
고용유지지원금은 코로나19 확산으로 인한 고용시장 충격을 최소화하기 위한 사회적 보장으로 고용안전망을 대표하는 제도이다. 이 절에서는 고용보험 가입자를 대상으로 지 원하는 고용유지지원금 지원 현황을 통하여 관광산업의 주요 업종별 수혜 현황을 점검 하고 특성을 파악하였다.

\section{가. 고용유지지원금 지원 현황(2021. 5월)}

올해 5월말 기준 고용유지지원금은 사업장 36,241 개소, 근로자 257,513 명(연인원 615,498 명)에 대해 652,363백만원 지원한 것으로 나타났다. 업종별로는 제조업(8,177 개소, 22.6\%), 도매 및 소매업(7,622개소, 21.0\%), 숙박 및 음식점업(4,661개소, $12.9 \%)$ 순으로 나타났다(고용노동부, 2021).

초기에는 제조업을 중심으로 유지지원금 신청이 크게 늘었으나, 서비스업 비중이 높 은 수도권으로 코로나가 확산되면서 사회적 거리 두기 등으로 서비스업의 신청 비중이 크게 증가한 것으로 나타났다.

〈표 4-18〉 업종별 고용유지지원금 지급 현황

\begin{tabular}{c|c|c|c|c|c|c}
\multicolumn{9}{|c|}{ 사업장 } & \multicolumn{2}{c}{ 순인원 } & \multicolumn{2}{c}{ 집행액 } \\
\hline 구분 & \multicolumn{2}{|c|}{ 개소, \%, 백만원) } \\
\hline 전체 & 36,241 & $(100)$ & 257,513 & $(100)$ & 652,363 & $(100)$ \\
\hline 제조업 & 8,177 & $(22.6)$ & 68,840 & $(26.7)$ & 118,106 & $(18.1)$ \\
\hline 도매 및 소매업 & 7,622 & $(21.0)$ & 36,314 & $(14.1)$ & 89,628 & $(13.7)$ \\
\hline 숙박 및 음식점업 & 4,661 & $(12.9)$ & 27,973 & $(10.9)$ & 68,636 & $(10.5)$ \\
\hline 사업시설관리업 & 3,837 & $(10.6)$ & 20,717 & $(8.0)$ & 72,259 & $(11.1)$ \\
\hline 교육 서비스업 & 3,230 & $(8.9)$ & 11,723 & $(4.6)$ & 27,966 & $(4.3)$ \\
\hline 기타 & 8,714 & $(24.0)$ & 91,946 & $(35.7)$ & 275,768 & $(42.3)$ \\
\hline
\end{tabular}

자료: 고용노동부 보도자료(2021.6.4.)

규모별로는 10인 미만 사업장 30,394개소(83.9\%), 10 30인 미만 사업장 4,521개 소(12.5\%), 30 100인 미만 사업장 1,044 개소(2.9\%) 순으로 나타났다. 코로나 19 의 영 향이 장기화되면서 300 인 이상 대규모 사업장의 신청 비중도 상대적으로 증가한 것으로 나타났다. 
〈표 4-19〉규모별 고용유지지원금 지급 현황

(단위: 개소, $\%$, 명, 백만원)

\begin{tabular}{c|c|c|c|c|c|c}
\hline 구분 & \multicolumn{2}{|c|}{ 사업장 } & \multicolumn{2}{c|}{ 순인원 } & \multicolumn{2}{c}{ 집행액 } \\
\hline 전체 & 36,241 & $(100)$ & 257,513 & $(100)$ & 652,363 & $(100)$ \\
\hline 10인미만 & 30,394 & $(83.9)$ & 86,493 & $(33.6)$ & 271,403 & $(41.6)$ \\
\hline 10 30인미만 & 4,521 & $(12.5)$ & 53,151 & $(20.6)$ & 117,290 & $(18.0)$ \\
\hline 30 100인미만 & 1,044 & $(2.9)$ & 36,586 & $(14.2)$ & 58,386 & $(8.9)$ \\
\hline 100 300인미만 & 205 & $(0.6)$ & 21,911 & $(8.5)$ & 35,752 & $(5.5)$ \\
\hline 300인이상 & 77 & $(0.2)$ & 59,372 & $(23.1)$ & 169,532 & $(26.0)$ \\
\hline
\end{tabular}

자료: 고용노동부 보도자료(2021.6.4.)

\section{나. 특별고용지원업종 고용유지지원금 지원 현황(2021. 5월)}

고용노동부는 코로나19로 인해 고용상황이 급격히 악화된 '관광, 여행 등 특별고용지 원 업종 지정 고시를 제정하고 고용유지지원금을 지급하고 있다. 2021년 5월말 기준 특별고용지원업종의 고용유지지원금 현황을 살펴보면, 전체 사업장 4,886 개소, 근로자 78,936 명에 대해 257,377 백만원을 지원한 것으로 나타났다. 업종별로는 집행액 기준 관광운송업(1,329억원, $51.7 \%$ ), 여행업(454억원, $17.7 \%$ ), 관광숙박업(242억원, 9.4\%) 순으로 나타났다.

〈표 4-20〉 업종별 특별고용지원업종 고용유지지원금 지급 현황

\begin{tabular}{c|c|c|c|c|c|c}
\multicolumn{9}{|c|}{ (단위: 개소, \%, 명, 백만원) } \\
\hline 구분 & \multicolumn{2}{|c|}{ 사업장 } & \multicolumn{2}{c|}{ 순인원 } & \multicolumn{2}{c}{ 집행액 } \\
\hline 전체 & 4,886 & $(100)$ & 78,936 & $(100)$ & 257,377 & $(100)$ \\
\hline 관광운송업 & 542 & $(11.1)$ & 37,311 & $(47.6)$ & 132,943 & $(51.7)$ \\
\hline 여행업 & 2,267 & $(46.4)$ & 11,275 & $(14.3)$ & 45,437 & $(17.7)$ \\
\hline 관광숙박업 & 438 & $(9.0)$ & 13,642 & $(17.3)$ & 24,154 & $(9.4)$ \\
\hline 전시국제회의업 & 791 & $(16.2)$ & 3,255 & $(4.1)$ & 13,528 & $(5.3)$ \\
\hline 항공기취급업 & 26 & $(0.5)$ & 4,612 & $(5.8)$ & 11,570 & $(4.5)$ \\
\hline 기타 & 822 & $(16.8)$ & 8,841 & $(11.2)$ & 29,745 & $(11.6)$ \\
\hline
\end{tabular}

자료: 고용노동부 보도자료(2021.6.4.) 


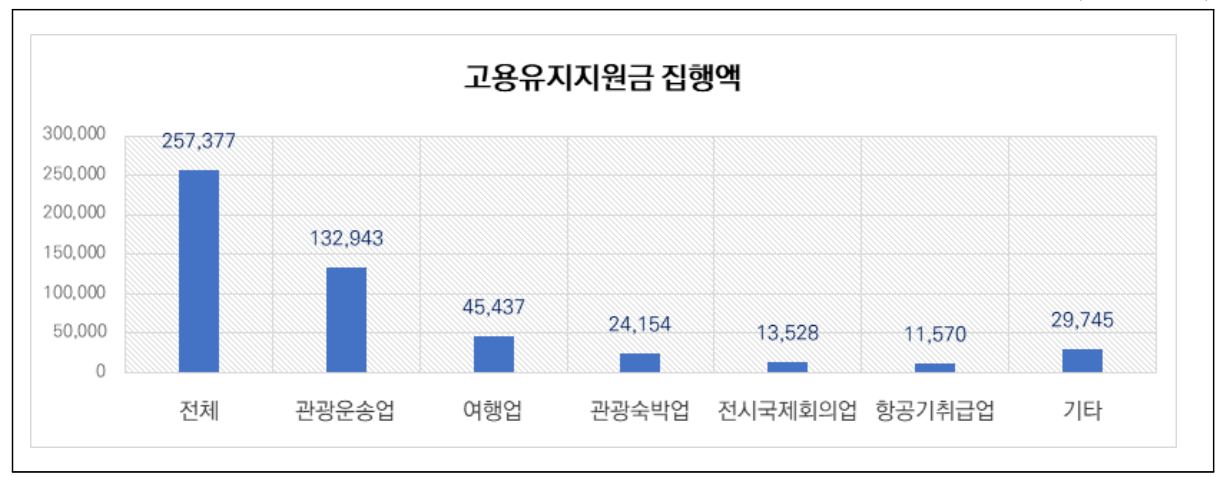

사업체 규모별로는 10 인 미만 사업장이 3,885개소(79.5\%), 10 30인 미만 사업장 676개소(13.8\%), 30 100인 미만 사업장 232개소(4.7\%) 순으로 나타났고, 지급인원 및 집행액 기준으로는 300 인 이상 사업장의 비중이 $50 \%$ 이상을 차지하였다.

〈표 4-21〉 규모별 특별고용지원업종 고용유지지원금 지급 현황

\begin{tabular}{c|c|c|c|c|c|c}
\multicolumn{9}{c|}{ (단위: 개소, \%, 명, 백만원) } \\
\hline 구분 & \multicolumn{2}{|c|}{ 사업장 } & \multicolumn{2}{c|}{ 순인원 } & \multicolumn{2}{|c}{ 집행액 } \\
\hline 전체 & 4,886 & $(100)$ & 78,936 & $(100)$ & 257,377 & $(100)$ \\
\hline 10인 미만 & 3,885 & $(79.5)$ & 11,134 & $(14.1)$ & 52,334 & $(20.3)$ \\
\hline 10 30인 미만 & 676 & $(13.8)$ & 8,335 & $(10.6)$ & 27,036 & $(10.5)$ \\
\hline 30 100인 미만 & 232 & $(4.7)$ & 8,386 & $(10.6)$ & 19,012 & $(7.4)$ \\
\hline 100 300인 미만 & 54 & $(1.1)$ & 8,748 & $(11.1)$ & 18,025 & $(7.0)$ \\
\hline 300인 이상 & 39 & $(0.8)$ & 42,333 & $(53.6)$ & 140,969 & $(54.8)$ \\
\hline
\end{tabular}

자료: 고용노동부 보도자료(2021.6.4.)

여행업과 관광숙박업의 고용유지지원금 수급 현황을 살펴보면, 2019년 관광사업체조 사의 사업체수와 종사자수 대비 지원 현황은 약 10 20\% 수준으로 나타났다. 여행업의 경우 사업체의 약 $12.4 \%$, 종사자의 $10.9 \%$ 가 지원을 받았고, 관광숙박업은 사업체의 $19.7 \%$, 종사자의 $19.3 \%$ 가 지급받은 것으로 추정된다. 
[그림 4-9] 고용유지지원금 지원 사업체 및 종사자 현황

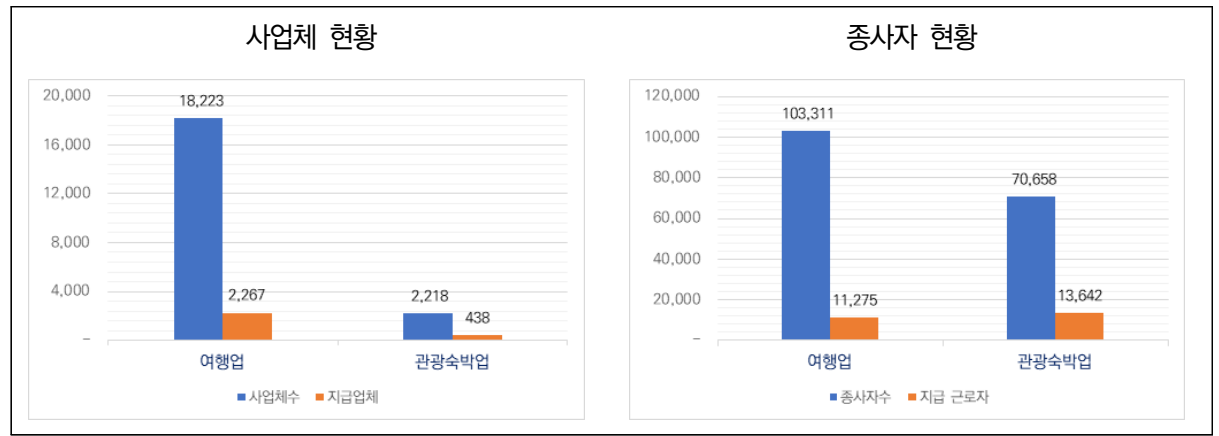

고용유지지원금 지원 확대는 사업주들이 해고가 아닌 휴업 또는 휴직으로 대응하여, 실업을 막기 위한 조치이다. 그럼에도 불구하고 코로나19로 인해 고용유지지원금 수급 과 관계없이 대부분의 업종에 걸쳐 피보험자 수가 감소한 것으로 나타났다. 다만, 동일 업종 내에서 1 회 이상 고용유지지원금 수혜를 받은 사업장 그룹의 평균 피보험자 감소는 상대적으로 낮은 수준을 보였다(장기영, 2021). 특별고용지원 업종으로 지정된 여행업 과 호텔업 등은 코로나19 장기화로 인한 영업피해 및 고용불안이 심각한 수준이고 회복 에도 상당 기간이 소요될 것으로 예상된다.

[그림 4-10] 고용유지지원금 수혜 업종 피보험자 수 증감률 비교

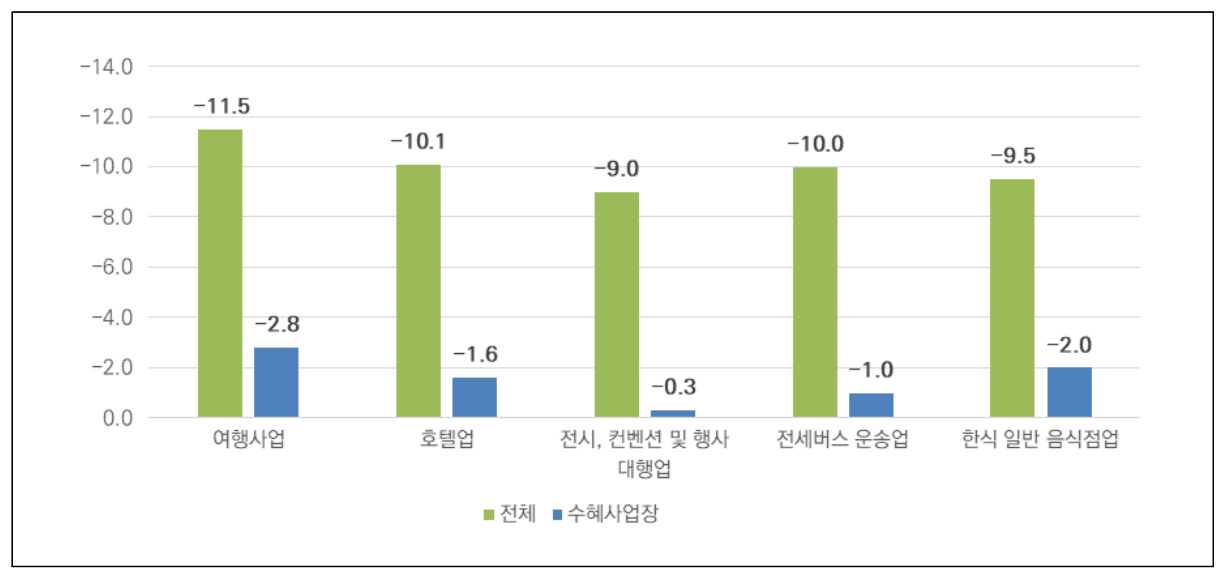

자료: 장기영(2021). 코로나19 주요 일자리사업 동향점검 및 국민체감도 분석 


\section{2. 긴급고용안정지원금 수급자 통계 분석}

\section{가. 조사 개요}

이 연구에서는 관광사업체를 대상으로 고용 현황 및 고용안전망 사각지대 실태 파악 을 위한 긴급고용안정지원금 수급자 통계 분석 결과를 활용하였다. 긴급고용안정지원금 은 일정 소득수준 이하인 특수형태근로종사자(이하 특고)·프리랜서가 코로나19 장기화 로 인해 소득이 감소한 경우, 생계안정을 위한 비용을 지원해주는 제도이다. 따라서 수 급자 통계를 분석하여 관광산업 고용안전망의 사각지대를 파악할 수 있다.

고용노동부(2020)의 발표에 따르면, 2020년 6월 1일부터 7월 20일까지 코로나19 긴급고용안정지원금 신청자는 175.6 만명이다. 근로형태별로는 영세 자영업자가 109.8 만명(62.5\%)으로 가장 많았고, 특고-프리랜서가 58.7만명(33.4\%), 무급휴직자가 7.1만 명(4.0\%) 순으로 나타났다. 연령별로는 40대(25.6\%)·50대(28.0\%)가 높은 비율을 차지 하였고, 영세자영업자는 50 60대 비율(55.2\%)이 가장 높았다.

〈표 4-22〉 코로나19 긴급고용안정지원금 지원사업

\begin{tabular}{|c|c|c|}
\hline 구분 & 내용 & 비고 \\
\hline $\begin{array}{l}\text { 1차 } \\
\text { 긴급고용안 } \\
\text { 정지원금 }\end{array}$ & $\begin{array}{l}\text { - 코로나 } 19 \text { 로 인해 소득·매출이 감소하였거나 무급휴직한 일정소득* 이하 } \\
\Delta \text { 특고·프리랜서 } \Delta \text { 영세 자영업자 } \Delta \text { 무급휴직자 지원 } \\
\text { (149만명, } 150 \text { 만원) } \\
\text { * 가구소득 중위 } 150 \% \text { 이하 또는 신청인 연소득 7천만원(연매출 } 2 \text { 억원) }\end{array}$ & $\begin{array}{l}\text { (지원규모) } \\
\text { 최대 150만원 } \\
\text { (월 50만원 } \times \\
\text { 3개월) }\end{array}$ \\
\hline $\begin{array}{l}\text { 2차 } \\
\text { 긴급고용안 } \\
\text { 정지원금 }\end{array}$ & $\begin{array}{l}\text { - 1차 긴급고용안정지원금을 지급 받은 특고·프리랜서 중 고용보험 미가 } \\
\text { 입자(50만명, } 50 \text { 만원) } \\
\text {-'19.12 '20.1월 중 특고·프리랜서로 활동한 자 중 '20.8월 또는 9월의 } \\
\text { 소득이 비교대상기간('19.8, '19.9, '20.6, '20.7, '19년 연평균) 대비 } \\
25 \% \text { 이상 감소한 자(20만명, 150만원) }\end{array}$ & \\
\hline
\end{tabular}

자료: 고용노동부 보도자료(2020.11.3.) 코로나19 긴급고용안정지원금 수급자 통계 분석 결과 


\section{나. 수급자 통계 분석 결과}

\section{1) 특고/프리랜서 직종별 수급자 현황}

특고·프리랜서 신청자를 직종별로 살펴보면, 종사자 비율이 높은 상위 5 개 직종은 보 험설계사(17.8\%, 10.5만명), 교육관련종사원(17.6\%, 10.3만명), 서비스관련종사원 (6.6\%, 3.9만명), 판매관련종사원(4.1\%, 2.4만명), 학습지교사(3.9\%, 2.3만명) 순으로 나타났다. 여가관광 관련 종사원은 6,852 명으로 약 $1.2 \%$ 를 차지하는 것으로 나타났다.

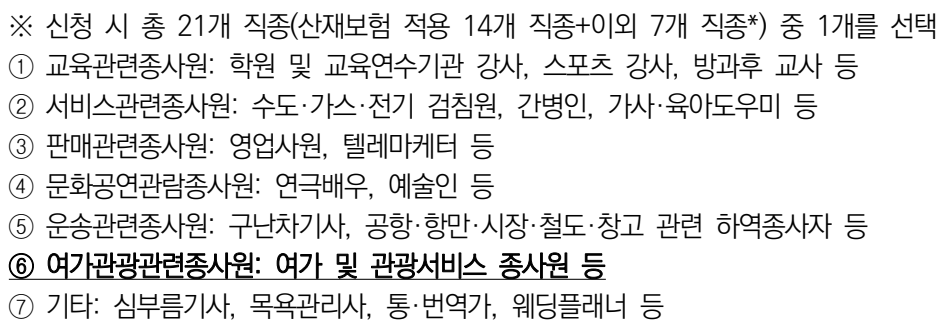

〈표 4-23〉 직종별 신청자 수

\begin{tabular}{c|c|c}
\hline 직종 & 신청자 수(명) & 비율(\%) \\
\hline 기타 & 143,936 & 24.5 \\
\hline 보험설계사* & 104,526 & 17.8 \\
\hline 교육관련종사원 & 103,267 & 17.6 \\
\hline 서비스관련종사원 & 38,581 & 6.6 \\
\hline 판매관련종사원 & 23,987 & 4.1 \\
\hline 학습지교사* & 22,744 & 3.9 \\
\hline 대리운전기사* & 22,581 & 3.8 \\
\hline 방문판매원* & 22,513 & 3.8 \\
\hline 문화공연관련종사원 & 19,203 & 3.3 \\
\hline 방문교사* & 11,243 & 1.9 \\
\hline 운송관련종사원 & 8,916 & 1.5 \\
\hline
\end{tabular}

\begin{tabular}{c|c|c}
\hline 직종 & 신청자 수(명) & 비율(\%) \\
\hline 여가관광관련종사원 & 6,852 & 1.2 \\
\hline 건설기계종사자* & 4,206 & 0.7 \\
\hline 대여제품방문점검원* $^{*}$ & 4,096 & 0.7 \\
\hline 퀵서비스기사* & 3,466 & 0.6 \\
\hline 화물자동차운전사* & 2,993 & 0.5 \\
\hline 신용카드회원모집인 & 2,451 & 0.4 \\
\hline 대출모집인 & 2,010 & 0.3 \\
\hline 택배기사* & 1,501 & 0.3 \\
\hline 가전제품설치기사* & 1,234 & 0.2 \\
\hline 골프장캐디* & 633 & 0.1 \\
\hline 총합(분류불능 포함) & 586,892 & 100 \\
\hline \multicolumn{2}{|c}{}
\end{tabular}

주1 : * 산재보험 적용 14 개 특고 직종 표시

주2 : 한국표준직업분류 상 '여가 및 관광 서비스 종사원(4321)'은 국내여행안내원, 국외여행안내원, 관광통역안내원, 미술관 박물관 해설 및 안내원, 전시 및 시설 견학안내원, 문화관광 및 숲자연환경 해설사가 해당

자료: 고용노동부 보도자료(2020.11.3.) 코로나19 긴급고용안정지원금 수급자 통계 분석 결과 


\section{2) 고용보험 가입 이력}

신청자의 고용보험 가입 이력을 살펴보면, 특고 수급자 중 지난 3년간('17 '19년) 고 용보험 가입이력이 한번이라도 존재하는 사람은 $22.0 \%$ 로, 특고와 임금근로자 간 이동하 는 것으로 확인되었다. 여가관광관련 종사원은 약 $24.2 \%$ 로 나타났다.

〈표 4-24〉 직종별 고용보험 가입이력

\begin{tabular}{c|c}
\hline 직종 & 3년 간 고용보험 가입률 \\
\hline 보험설계사 & 18.9 \\
\hline 골프장캐디 & 16.5 \\
\hline 학습지교사 & 10.8 \\
\hline 건설기계종사자 & 27.8 \\
\hline 택배기사 & 31.7 \\
\hline 퀵서비스기사 & 31.4 \\
\hline 대출모집인 & 24.7 \\
\hline 신용카드회원모집인 & 12.0 \\
\hline 대리운전기사 & 21.4 \\
\hline 방문판매원 & 12.7 \\
\hline 방문교사 & 17.7 \\
\hline
\end{tabular}

\begin{tabular}{|c|c|}
\hline 직종 & 3년 간 고용보험 가입률 \\
\hline 대여제품방문점검원 & 20.3 \\
\hline 가전제품설치기사 & 23.2 \\
\hline 회물자동차운전사 & 19.7 \\
\hline 교육관련종사원 & 20.4 \\
\hline 운송관련종사원 & 26.2 \\
\hline 여가관광관련종사원 & 24.2 \\
\hline 판매관련종사원 & 25.5 \\
\hline 문화공연관련종사원 & 26.0 \\
\hline 서비스관련종사원 & 31.6 \\
\hline 기타 & 25.8 \\
\hline 전체 & 22.0 \\
\hline
\end{tabular}

자료: 고용노동부 보도자료(2020.11.3.). 코로나19 긴급고용안정지원금 수급자 통계 분석 결과 


\section{3) 직종별 연령}

신청자의 직종별 연령을 살펴보면, 여가관광관련종사자는 20 대 미만에서 30 대의 비 중이 $58.3 \%$ 로 나타났고, 60 대 이상은 $14 \%$ 로 타 직종보다 높게 나타났다.

[그림 4-11] 신청자 연령별 분포

(단위: \%)

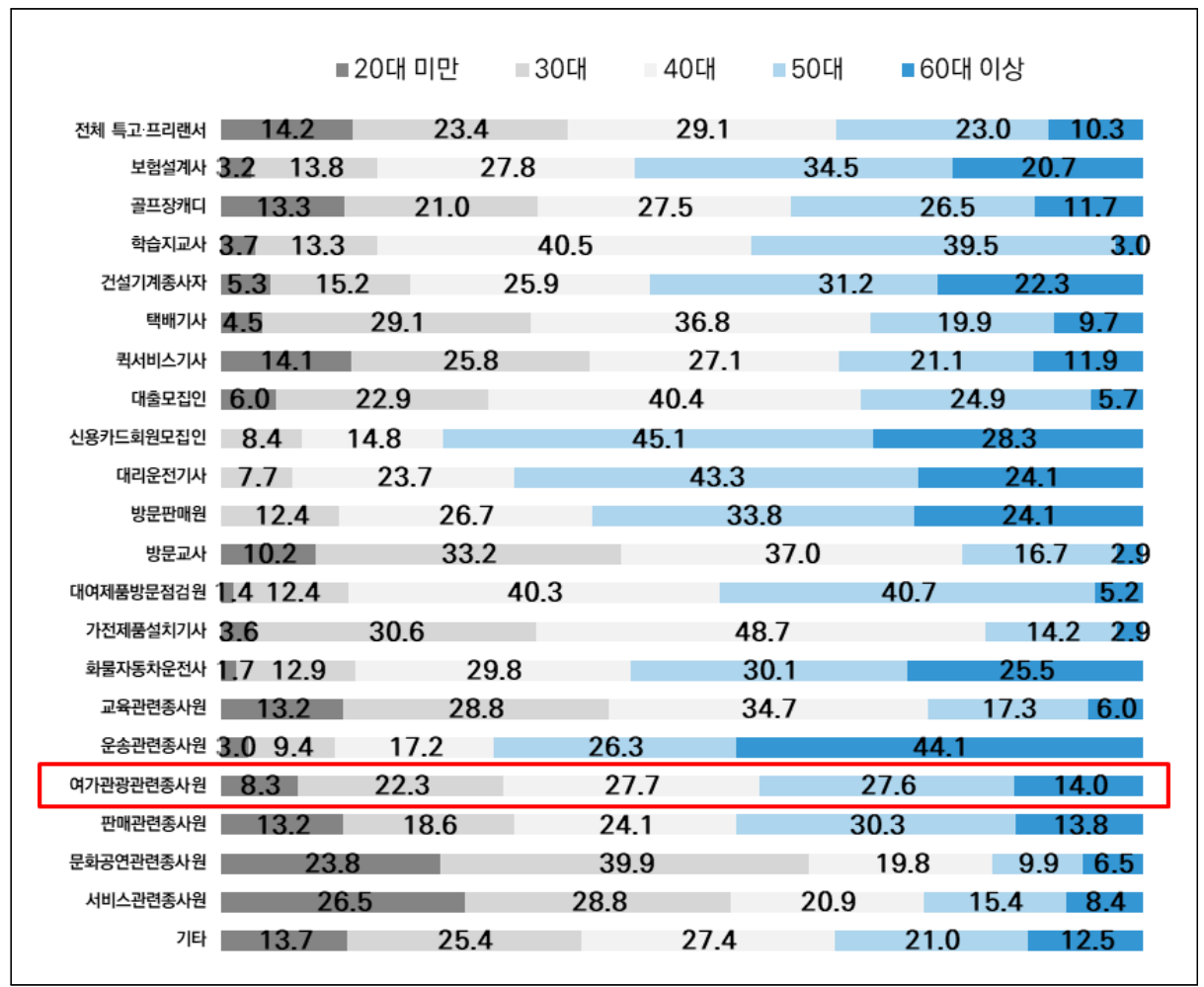

자료: 고용노동부 보도자료(2020.11.3.). 코로나19 긴급고용안정지원금 수급자 통계 분석 결과 


\section{4) 직종별 소득구간 분포}

신청자의 직종별 소득구간 분포를 살펴보면, 여가관광관련 종사원은 1 2분위 구간이 $58.9 \%$ 로, 전체 수급자 기준 $48.7 \%$ 보다 비중이 높았다. 코로나 19 긴급고용안정지원금 수급자 기준으로 볼 때 타 직종에 비해 저소득 구간의 비중이 높게 나타났다.

\section{[그림 4-12] 소득구간 분포: 직종별}

(단위: \%)

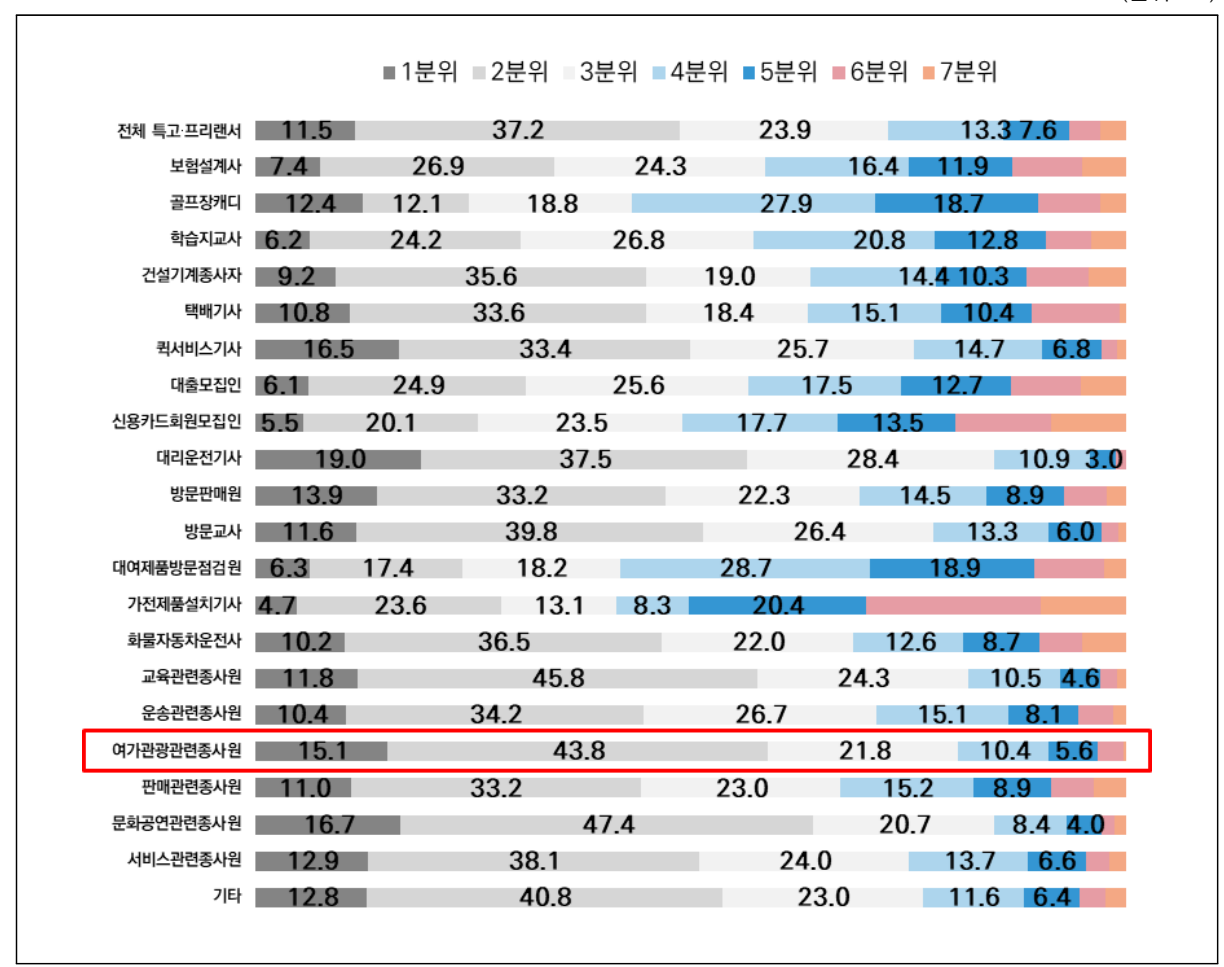

자료: 고용노동부 보도자료(2020.11.3.). 코로나19 긴급고용안정지원금 수급자 통계 분석 결과

\section{5) 소득 감소율}

긴급고용안정지원금 수급자의 평균 소득 감소율은 $69.1 \%$ 로, 전체 수급자의 $41.0 \%$ 가 $80 \%$ 이상 소득이 감소된 것으로 나타났다. 여가관광관련종사원의 평균 소득 감소율은 $85.1 \%$ 로, 전체 대비 $16.0 \% \mathrm{p}$ 높게 나타났고, 이 중 $72.6 \%$ 가 $80 \%$ 이상 소득이 감소된 것으로 나타났다. 코로나 19 의 영향으로 전체 산업 대비 여가관광관련종사원의 소득 감 소가 매우 큰 것으로 분석된다. 
〈표 4-25〉 소득 감소율

\begin{tabular}{|c|c|c|c|}
\hline & 구분 & 전체 & 여가관광 관련 종사원 \\
\hline & 평균 & 69.1 & 85.1 \\
\hline & $40 \%$ 미만 & 18.3 & 5.3 \\
\hline & $40 \%$ 이상 60\% 미만 & 22.7 & 11.6 \\
\hline 주난 & $60 \%$ 이상 80\% 미만 & 18.0 & 10.5 \\
\hline & $80 \%$ 이상 & 41.0 & 72.6 \\
\hline
\end{tabular}

수급자의 소득감소율은 $60 \%$ 이상인 경우가 절반(59.0\%) 이상을 차지했으며, 특히, 여가관광관련종사원은 소득감소율 $80 \%$ 이상이 전체의 $72.6 \%$ 로 심각한 소득감소를 겪 고 있는 것으로 나타났다. 코로나19로 특고·프리랜서 등이 고용안전망의 사각지대에 놓 여 있는 노동 취약계층임이 확인되었다.

[그림 4-13] 소득감소율 분포: 직종별

(단위: \%)

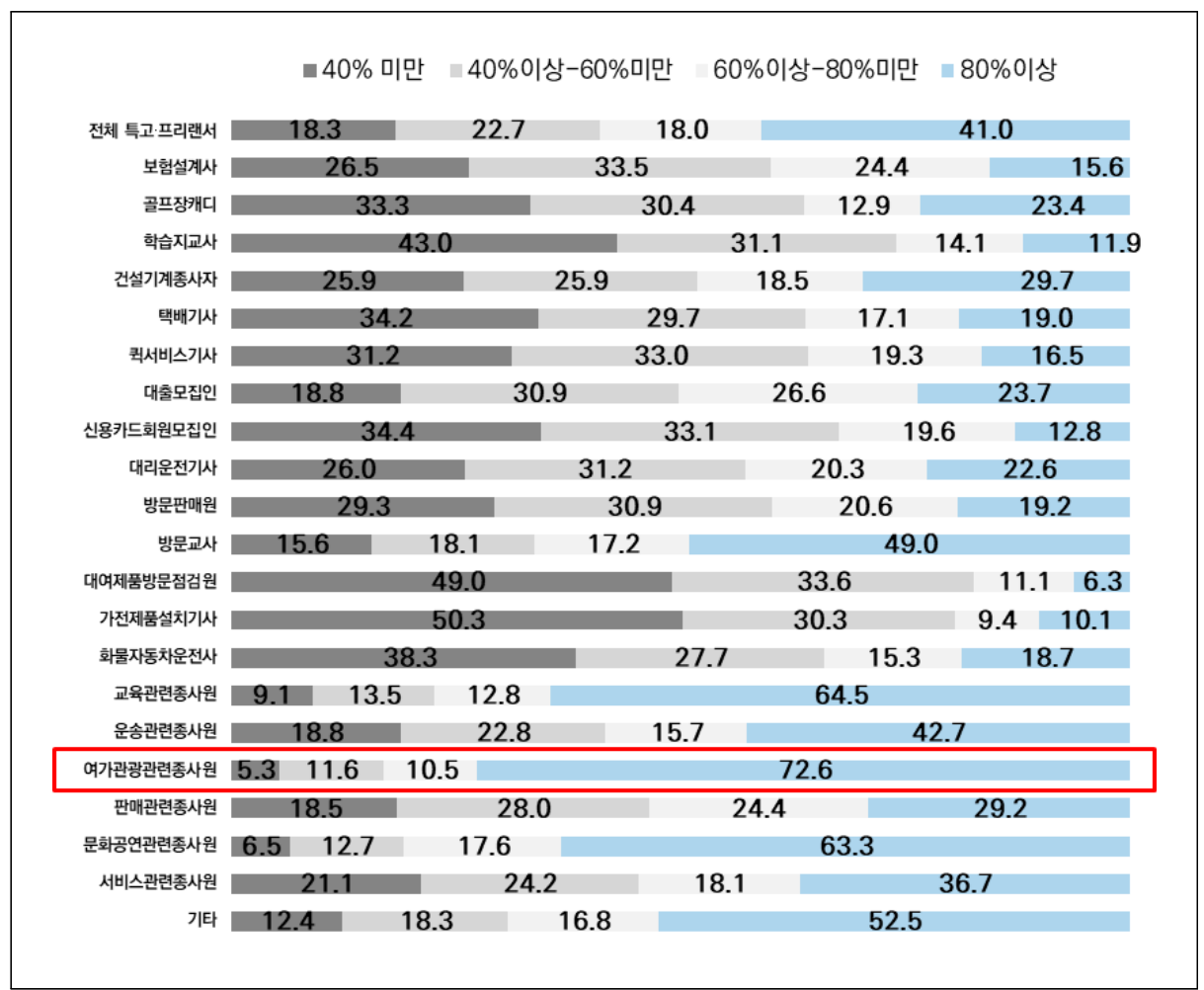

자료: 고용노동부 보도자료(2020.11.3.). 코로나19 긴급고용안정지원금 수급자 통계 분석 결과 


\section{6) 여가 및 관광 관련 종사원 소득 현황}

긴급고용안정지원금을 신청한 여가 및 관광 관련 종사원의 연평균 소득은 약 3,300 만 원이고, 세부적으로 분포를 살펴보면, 1,000 2,000만원 미만(27.0\%), 500 1,000만원 미만(20.9\%)이 20\%를 상회하며 상대적으로 높게 나타났다.

[그림 4-14] 여가 및 관광 관련 종사원 소득 현황

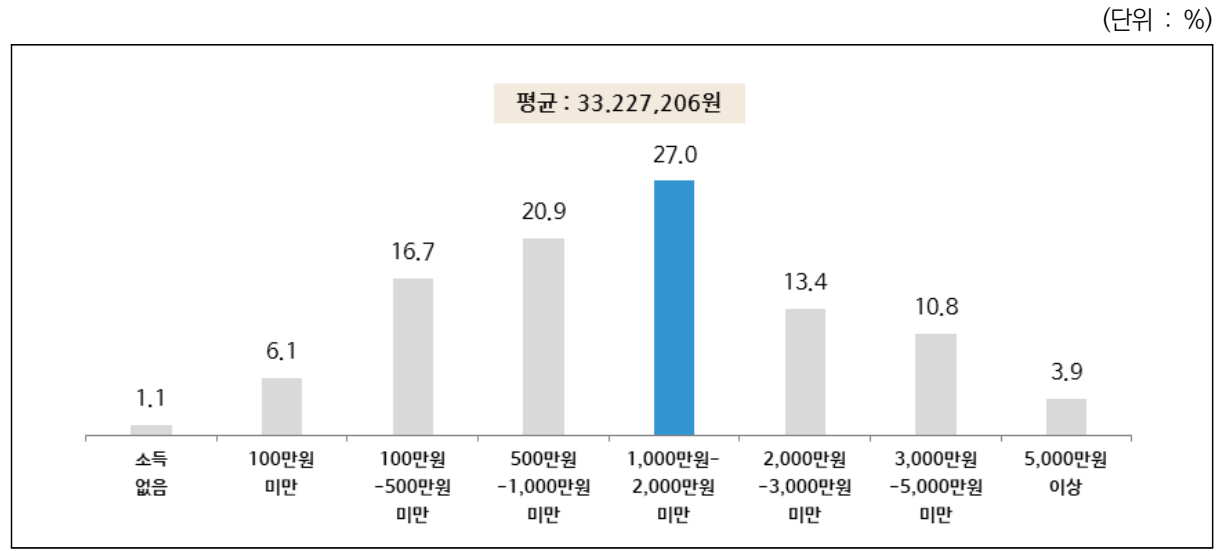

7) 여가 및 관광 관련 종사원 근무 기간

긴급고용안정지원금을 신청한 여가 및 관광 종사원의 근무 기간은 평균 3 년으로 나타 났다. 세부적으로 1 2년 미만 근무기간 종사원이 27.9\%로 가장 높고, 5년 이상 (17.3\%), 6개월 1년 미만(14.2\%) 등의 순으로 조사되었다.

[그림 4-15] 여가 및 관광 관련 종사원 근무 기간

(단위 : \%, 무응답 제외)

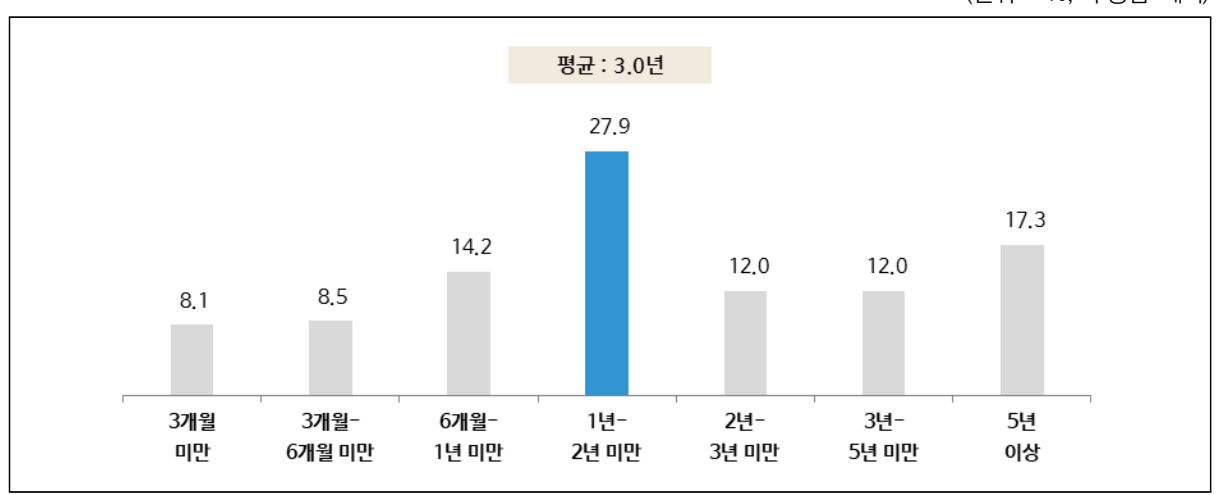




\section{제3절 관광산업 고용안전망 실태 파악을 위한 심층인터뷰 결과}

\section{1. 조사 개요}

\section{가. 조사 설계}

이 연구에서는 관광산업 고용안전망 사각지대 실태 파악을 위하여 심층인터뷰 조사를 실시하였다. 관광산업 고용안전망에 대한 진단과 접근을 위한 초기 단계의 탐색적 연구 라는 점에서 질적 접근이 유효하다고 판단하였다.

심층인터뷰 방법은 다음과 같다. 우선 고용보험 사각지대의 비중이 높은 업종 및 직종 해당자를 우선적으로 선발하였다. 2019년 기준 업종별 관광산업 종사자 구성을 살펴보 면, 여행업 $37.5 \%$, 관광숙박업 $25.6 \%$ 로 전체의 $60 \%$ 이상을 차지하고 있다. 또한 2020 년 기준 특별고용지원업종으로 지정된 여행업, 관광숙박업, 국제회의기획업 종사자를 중 심으로 총 28명의 인터뷰 대상자를 선발하였다.

인터뷰 기간은 2021년 7월부터 8월까지 2개월이며, 인터뷰는 연구자가 직접 진행하 였고, 질의서는 업종별, 직위별 특성에 따른 문항을 별도로 추가하여 진행하였다. 인터 뷰 진행 시간은 60 90분으로, 코로나19 상황을 고려하여 대부분 온라인 화상회의로 진 행하였다. 인터뷰 진행 후 필요에 따라 서면 의견서를 요청하여 내용을 확인하였다.

〈표 4-26〉 심층인터뷰 조사 계획

\begin{tabular}{c|l}
\hline 구분 & \multicolumn{1}{c}{ 내용 } \\
\hline 조사 대상 & - 관광산업 종사자(여행업, 관광숙박업, 국제회의기획업) \\
\hline \multirow{2}{*}{ 조사 방법 } & $-1: 1$ 면접조사(경우에 따라 그룹 단위로 진행) \\
& - 온라인 화상회의로 진행, 1인 60분 90분 소요 \\
\hline \multirow{2}{*}{ 조사 기간 } & $\begin{array}{l}\text { - 2021년 7월 8월 } \\
\text { (사전 인터뷰 진행 : 4.12. 5.15) }\end{array}$ \\
\hline 조사 내용 & - 근로(활동) 현황, 코로나19로 인한 피해 현황, 고용안전망 필요성 등 \\
\hline
\end{tabular}




\section{나. 인터뷰조사 참여자}

인터뷰 참여자는 최소 1년 이상 사업 혹은 직업경력이 있는 관광업계 종사자를 섭외 하였다. 인터뷰 대상자 선정 시, 관광가이드(관광통역안내사)의 경우 시장별 특성을 반영 하기 위하여 영어, 일어, 중국어와 동남아로 구분하였고, 호텔업은 규모에 따라 4 5성급 호텔, 3성급 호텔, 휴양콘도미니엄을 구분하여 섭외를 진행하였다.

심층인터뷰조사는 업종별 종사자, 종사자 대표 역할을 하는 노조위원장, 업종별 사업 체 인사담당자 및 실무자, 관련 협회 관계자 등 총 28 명이 참여하였다. 참여자는 모두 임의의 ID로 처리했으며, 심층인터뷰 참여자의 개요는 다음과 같다.

〈표 4-27〉 심층인터뷰 참여자 현황

\begin{tabular}{|c|c|c|c|c|}
\hline ID & 구분 & 부서/직급 & 비고 & 인터뷰 날짜 \\
\hline$A-1$ & 숙박업 & 노조위원장 & 서울, 5성 호텔 & 7/29(목) 줌 \\
\hline$A-2$ & 숙박업 & 노조위원장 & 서울, 3성 호텔 & 7/29(목) 줌 \\
\hline$A-3$ & 숙박업 & 노조위원장 & 서울, 5성 호텔 & 8/11(수) 줌 \\
\hline$A-4$ & 숙박업 & 노조위원장 & 강원, 휴양콘도미니엄 & 8/10(화) 줌 \\
\hline$A-5$ & 숙박업 & 경영지원실 & 서울, 3성 호텔 & 4/15(목) \\
\hline$A-6$ & 숙박업 & 협회 & - & 4/15(목) \\
\hline$A-7$ & 숙박업 & 노조위원장 & 강원 & 8/10(화) 줌 \\
\hline$A-8$ & 숙박업 & 경영지원실 & 부산, 3성 호텔 & 8/26(목) 줌 \\
\hline $\mathrm{B}-1$ & 여행업 & 상무 & - & 4/12(월) \\
\hline $\mathrm{B}-2$ & 여행업 & 종사자 & - & 7/30(금) 줌 \\
\hline$B-3$ & 여행업 & 노조위원장 & - & 8/11(수) 줌 \\
\hline$B-4$ & 여행업 & 노조위원장 & - & 8/5(목) 줌 \\
\hline$B-5$ & 여행업 & 상무 & 관광통역안내사(중국) & 8/4(수), 대면 \\
\hline $\mathrm{B}-6$ & 여행업 & 전속가이드 & 일본 쓰루가이드 & 7/23(금), 줌 \\
\hline $\mathrm{B}-7$ & 여행업 & 전속가이드 & 일본 쓰루가이드 & 7/24(토), 줌 \\
\hline $\mathrm{B}-8$ & 여행업 & 전속가이드 & 일본 쓰루가이드 & 4/15(목) \\
\hline B-9 & 여행업 & 프리랜서 & 일본 현지가이드 경력 & 4/13(화) \\
\hline$B-10$ & 여행업 & 협회 & - & 7/21(수), 줌 \\
\hline$B-11$ & 여행업 & 관광통역안내사 & 영어, 여성 & 7/30(금), 줌 \\
\hline$B-12$ & 여행업 & 관광통역안내사 & 중국어, 남성 & 7/30(금), 줌 \\
\hline$B-13$ & 여행업 & 관광통역안내사 & 일어, 여성 & 7/30(금), 줌 \\
\hline$B-14$ & 여행업 & 관광통역안내사 & 태국어, 여성 & 7/30(금), 줌 \\
\hline$B-15$ & 여행업 & 관광통역안내사 & 일어, 정규직 & 7/27(화), 줌 \\
\hline $\mathrm{C}-1$ & 국제회의기획업 & 실장(종사자) & 신생(정규직 3인 이하) & 7/28(수) 줌 \\
\hline$C-2$ & 국제회의기획업 & 대표 & 중소 & 7/28(수) 줌 \\
\hline
\end{tabular}




\begin{tabular}{c|c|c|c|c}
\hline ID & 구분 & 부서/직급 & 비고 & 인터뷰 날짜 \\
\hline C-3 & 국제회의기획업 & 팀장(종사자) & 중소, 이직 경험 3회 & $7 / 30$ (금) 줌 \\
\hline C-4 & 국제회의기획업 & 대표 & 중견, 정규직 20명 내외 & $7 / 28$ (수) 줌 \\
\hline C-5 & 국제회의기획업 & 프리랜서 & 정규직 후 프리랜서 전환 & 8/29(일) 줌 \\
\hline
\end{tabular}

\section{다. 심층인터뷰 조사 내용}

심층인터뷰는 반구조화된 질문지를 중심으로, (1) 관광산업 노동시장 현황 및 특성, (2) 코로나19 이후 일자리 위기 상황 및 동향, (3) 관광산업의 고용안전망 실태 및 사각지대 파악, (4) 고용안전망 구축을 위한 제도적 지원방안으로 구성-진행하였고, 인터뷰 도중 중요하게 나타나는 이슈와 질의를 추가하였다.

〈표 4-28〉 심층인터뷰 질의 내용

\begin{tabular}{|c|c|}
\hline 구분 & 내용 \\
\hline \multirow{4}{*}{$\begin{array}{l}1 \text { 관광산업 노동시장 } \\
\text { 현황 및 특성 }\end{array}$} & $\begin{array}{l}\text { - 입직 : 업종별 진입장벽, 신규 진입 특성 } \\
\text { - 업종별 진입장벽은 어떠한가요? } \\
\text { - 관광숙박업 종사자수 통계의 사업체수 대비 종사자수 지속 감소 이유는? }\end{array}$ \\
\hline & $\begin{array}{l}\text { - 이직 : 이직률, 이직의 원인 } \\
\text { - 업계의 이직률은 어떠한가요? 이직의 원인은 무엇인가요? } \\
\text { - 안정적 고용 유지를 위한 기업의 자체 노력은 무엇인가요? }\end{array}$ \\
\hline & - 급여수준 및 처우(업계 평균 기준으로 응답) : 근무 시간, 복리후생 \\
\hline & $\begin{array}{l}\text { - 경력관리, 업의 전문성 } \\
\text { - 업종 내 종사자의 경력관리는 어떻게 이루어지는가? }\end{array}$ \\
\hline \multirow{3}{*}{$\begin{array}{l}2 \text { 코로나19 이후 } \\
\text { 일자리 위기 상황 및 } \\
\text { 동향 }\end{array}$} & - 코로나19 관련 휴직, 정리해고 등 고용 관련 이슈 \\
\hline & $\begin{array}{l}\text { - 코로나19 관련 고용유지지원금 등 정부지원정책 수혜 현황 } \\
\text { - (수혜자) 지원 내용, (비수혜자) 제약요인 } \\
\text { - 코로나19 관련 정부지원정책의 효과와 한계는 무엇인가요? }\end{array}$ \\
\hline & - 코로나 이후 직무 변화, 고용시장의 변화 \\
\hline \multirow{3}{*}{$\begin{array}{l}3 \text { 관광산업의 } \\
\text { 고용안전망 실태 및 } \\
\text { 사각지대 파악 }\end{array}$} & $\begin{array}{l}\text { - 고용형태 및 특성 } \\
\text { - 상용, 임시 및 일용, 자영업, 초단시간, 프리랜서 등 }\end{array}$ \\
\hline & $\begin{array}{l}\text { - 고용보험 가입 현황, 미가입 이유 } \\
\text { - 4대 보험 : (관광가이드) 산재보험 가입 } \\
\text { - 근로계약서 체결 : (관광가이드) 표준계약서 체결 }\end{array}$ \\
\hline & $\begin{array}{c}\text { - 고용안전망의 사각지대에 놓여있는 근로자는 누구인가요? } \\
\text { - 근무 형태, 업종별 직무의 특성, 사각지대 보호 조치 }\end{array}$ \\
\hline \multirow{3}{*}{$\begin{array}{l}4 \text { 고용안전망 구축을 } \\
\text { 위한 정책 제언 }\end{array}$} & $\begin{array}{l}\text { - 직업의 비전, 미래에 대한 전망 } \\
\text { - 직업 안정성에 대한 인식 }\end{array}$ \\
\hline & $\begin{array}{l}\text { - 특고, 프리랜서 등 고용보험 적용 대상 확대 필요성 } \\
\text { - 전국민 고용보험제도 관련 적용 필요성 }\end{array}$ \\
\hline & - 고용안전망 구축을 위한 정책적, 제도적 지원 사항 \\
\hline
\end{tabular}




\section{2. 심층인터뷰 결과: 여행업}

\section{가. 노동시장 및 직무 특성}

여행업은 고용의 변동이 큰 영역으로 나타났다. 이는 여행업의 진입장벽이 높지 않고, 고도의 전문 기술을 필요로 하는 직무가 아니라는 인식에 기초한다. 사업주 입장에서 '여행업은 사람을 쉽게 뽑을 수 있다'는 인식은 종사자의 고용 불안정성을 높이는 이유 가 된다.

여행업에 처음 들어오시는 분들은 학교에서 여행을 전공하는 사람도 들어오긴 합니다만 전혀 관계 없는 사람이 들어오기도 하거든요. 일단 와서 일을 배우는 거 자체는 커다란 스킬이 필요해 보이진 않아요. 처음 에 와서 3 6개월 정도 일하면 어느 정도 적응 할 수 있는 부분이 있지 않나 싶어요. 그래서 진입장벽이 높지 않은 부분도 있다고 생각하고요. (중략) 그러다 보니까 이직률... 타 회사 같은 여행업계 내에서 이동 도 있지만 전혀 다른 분야로 다시 이직한다거나 그런 경우도 있는 거 같고요. (중략) 여행사에는 어떻게 보면 젊은 사람이 차장, 부장 이렇게 된 경우도 많고, 워낙 자주 사람들이 바뀌고, 자주 교체되고 하기 때문에 직급은 높지만 급여는 그렇게 많지 않고 자주 바뀌고 그런 측면도 있는 거죠.

$\langle\mathrm{B}-4\rangle$

실제 여행업 종사자의 스펙이 매우 낮습니다. 여행업은 NCS 수준을 봐도 낮은, 고졸도 충분히 할 수 있는 업무입니다. 그런 업무 특성이 있고, 그래서 연봉 수준이 낮고, 스펙도 낮습니다. 스펙 좋은 친구들이 간혹 오는데 많이 못버팁니다. (중략) 중개, 알선업의 성격이고, 단순 반복 업무이죠.

$\langle\mathrm{B}-1\rangle$

노동자 입장에서 보면 고용에 대한 안전성이라든지 고용에 대한 유지가 가장 중요한 이슈라고 생각을 하는 데, 경영을 맡은 사측은 여행업은 사람을 금방 뽑을 수 있다고 생각하는 것 같습니다.

$\langle\mathrm{B}-3\rangle$

여행업 종사자의 이직 사유는 낮은 급여 수준, 타 업종과의 급여 차이 등에서 기인한 다. 여행업이 고용 창출은 높으나 노동생산성이 낮은 업종이라는 인식을 갖고 있으며, 낮은 수익구조를 갖고 있다고 보았다. 이는 여행업이 저가 상품 개발, 가격 경쟁이 치열 한 시장이라는 구조적 문제와 연결된다.

월급이 너무 적다, 회사 사이즈는 커졌는데 직원에 대한 대우는 열악하다는 불만이 생기면서 어느 순간 연봉과 스펙이 높아졌습니다. 대략 2007년 이후의 흐름입니다. 근데 그 직원들도 다른 곳에 비해 연봉이 낮은 수준입니다...처음엔 비슷하나 갈수록 연봉 차이가 벌어집니다. (중략) 여행업의 특성이 대단한 기술 을 갖지 않은 사람들을 많이 고용하기 좋은 산업이고, 그러다 보니, 고용창출이 높죠. 그러나 노동생산성이 매우 낮습니다.

$\langle\mathrm{B}-1\rangle$ 
항공은 수익이 많이 나는 사업이에요. 여행업이 굉장히 유망하고 과거에 그렇게 많이 생각했지만 실제적으 로 수익 내기 어려운 사업이에요. 저희 회사도 수년간 계속 적자를 유지해 왔거든요. 아시다시피 워낙 경쟁 이 치열에서 399,000원, 베트남 가도 299,000원, 그건 항공료도 안 나오거든요. 쥐어짜고 다른 쪽 수익 쇼핑이라든가 이런 걸 하느라고 편법도 개발해야 하고 하는 과정에서 경쟁이 치열하다 보니까 회사가 수익 을 내기 어려운 구조에요. 그러다 보니까 아무래도 급여가 올라가기 어렵겠죠.

$\langle\mathrm{B}-4\rangle$

관광가이드의 경우 과거에는 '민간외교관' 으로 자부심이 있었으나, 현재는 전문성이 약화되고, 진입장벽 또한 낮아지는 추세이다. 관광통역안내사 자격증의 위상도 과거와는 큰 차이가 있다는 것이 인터뷰 참여자들의 공통된 인식이었다.

관광진흥법에 보시면 관광통역안내사가 외국인 관광객을 상대로만 일을 하게 되어 있잖아요. 그러다 보니 까 본인들이 외국인들이 봤을 때 최일선에서 일하는 민간외교관이라는 자부심들이 있으세요. $\langle\mathrm{B}-10\rangle$

\section{나. 코로나19 이후 일자리 위기 상황 및 주요 이슈}

코로나19 이후 여행업이 위기에 놓이면서 유급, 무급휴직과 정리해고 등 고용 문제가 가시화되었다. 여행업은 초기의 고용유지지원금에도 불구하고, 대부분 구조 조정이 불가 피한 상황에 놓여있는 것으로 나타났다. 구조 조정의 우선순위는 계약직, 기존 인력 중 직무 변화가 예상되는 부분에서 진행되었다.

저희 직원들의 한 $60 \%$ 이상이 휴직을 실시했고요. 지금도 $60 ~ 70 \%$ 되는 직원들이 휴직을 실시해왔고. 다행히 지금까지는 정부지원금을 받고 있어서 $70 \%$, 지금은 좀 더 줄어서 $65 \%$ 정도를 받고 있습니다만 그 정도 된 직원들이 현재까지 휴직을 했고요. 물론 회사가 다른 회사도 그렇겠지만 1년 반 이상을 계속 휴직을 유지해 올 수 없었을 거예요. 저희 회사도 작년 11월 말에 구조조정을 이미 실시했어요. 휴직을 작년 3월부터 한 6 7개월 이상 실시를 했고, 이후에 이제 이 정부지원금 받는 기간 동안 구조조정이 안 되기 때문에 회사에서 전후 기간 1 3개월 정도를 회사 자금으로 휴직 급여를 지급하면서 구조조정을 단행 했거든요. 조합에서는 당연히 동의를 안 하는 게 맞지만, 여러 직원들의 의견을 수렴해서 투표를 통해서 어느 정도 구조조정을 받아 들여서 희망퇴직을 해서 거의 $40 ~ 50 \%$ 되는 인원들이 정리가 됐어요. 저희가 원래는 한 기존에 230 명 정도의 종업원 수가 있었는데, 올해 기준으로 123 명 정도로 줄었거든요. 그 안에 는 구조조정 된 안에는 정규직 외에 약 100 여명 정도가 구조조정이 됐는데, 거기에는 30 여명 정도의 계약 직이 포함되어 있어요. 계약직은 당연히 계약을 연장 안 함으로 종료가 될 것이고 나머지 인원은 희망퇴직 에 의해서 어떻게 보면 약간의 강제성은 있었습니다만, 희망퇴직으로 인해서 정리가 많이 됐고요. 그리고 그 중에 저희가 10 명 정도가 프리랜서 가이드들이 있었어요. 가이드는 프리랜서는 아니었고, 회사가 계약 직 신분으로 2 년 이상 돼도 계약직을 해왔기 때문에 거기는 어떻게 보면 무기계약직이 되는 것이죠. 그분들도 유지를 했었는데 그분들은 정부 지원금을 받지 않았어요. 왜냐하면 그분들은 프리랜서 식으로 일을 했기 때문에 기존 급여가 기본급이 작아요. 거기에서 정부지원금을 받는다 한들 사실 20 만원도 안되 는 금액을 받거든요. 기존에 지급하던 건 회사에서 얼마 안 됐기 때문에 지급을 했었고, 작년에 모든 계약 직과 프리랜서식의 무기계약직까지 정리가 된 상황입니다.

〈B-4〉 
정부의 코로나19 지원 정책 수혜 관련하여, 관광가이드 직종은 정책의 사각지대에 놓 여있는 것으로 나타났다. 관광가이드는 긴급고용안정지원금 신청시 비공식근로의 특성 때문에 근로를 입증하기 어려워 신청할 수 없다는 응답도 있다. 수급자의 경우도, 제출 서류가 방대하고 절차가 까다롭다는 응답도 있다. 예컨대 중국 가이드의 경우 급여를 현찰로 주는 관행이 지배적이어서 근로를 입증할 수 없는 비공식 노동형태가 여전하기 때문이다.

원천징수 내고 고용했다는 걸 업소 별로 받아야 해요. (중략) 월별로 있어야 하고 서류가 한 쇼핑센터 당 보통 3장 들어간 거 같아요. 쇼핑센터 10군데 다 받았고, 통장 1년치를 집에 있는 모든 통장을 전부 카피 해서 달라고 하더라고요. 1년치 다 해주고 은행 거래가 10 군데면 10 군데 다 해야 하는 거예요. 저는 서류 거의 100 장 냈어요. (중략) 저희는 그 여행사 일만 함에도 불구하고 그 여행사 직원도 아니고, 알바도 아니고 정말 그 여행사에 있는데 여행사에서는 고용했다는 경력증명서 한 장 재직증명서 한 장을 받을 수 없는 현실이잖아요. 정말 책상에 앉아서 경리를 한 번 업무를 한 번 본 것도 아닌, 업소에서 물건 팔았 다는 이유 하나만으로 10 개 업소의 직원으로 증명서 받으러 다니는 것들, 이게 좀 이 체계가 아니었던 거 같아서 회사에 들어가면 프리랜서도 재직이 가능하잖아요. 재직을 하고 회사에서 파견 나가는 식으로. 파견 나가는 형태로 하면 될 텐데, 그게 우리나라 직업법상으로도 그게 되어 있는데 왜 이 친구들은 그렇 게 안 할까? 그런 생각이 들었어요. $\langle B-14\rangle$

손님한테 현찰로 받았습니다. 그게 근거 자료가 어디 있어요? 손님한테 오고 가는 현찰 거래인데, 면세점 매출은 잡혀 있지만 그거 잡힌 거 약간이지 그 다음은 그것도 사드 이후에는 없었고. 손님한테 현찰로 서로 주고받았는데, 그러면 없죠. 법적으로는.

$\langle\mathrm{B}-12\rangle$

\section{다. 고용안전망 사각지대 및 실태}

\section{1) 여행업 사각지대 - 관광가이드}

여행업의 대표적인 사각지대는 프리랜서로 활동하는 관광가이드이다. 인바운드 관광 에서는 관광통역안내사, 아웃바운드 관광에서의 국외여행인솔자(TC) 등이 포함된다.

가이드라든가 사각지대 분들이 많은데. 어떻게 보면 그분들은 많은 피해를 봤을 거예요. 정규직과 같이 보호막도 노동조합이라는 보호막도 없었을 것이고요. 그분들은 고용유지지원금 같은 경우에 기존 기본금 자체가 작아서 사실 지원 받아도 그런 금액에 대한 한계가 있었고, 그 다음에 나중에 실업급여 받더라도 물론 고용보험 이런 것도 계속 내고는 있었거든요. 그런데 금액 자체가 작았고, 급여가 낮았기 때문에 제대 로 그런 보상을 받지 못한 걸로 알고 있어요.

$\langle\mathrm{B}-4\rangle$

관광가이드는 대표적인 프리랜서 업종으로 볼 수 있다. 특히 아웃바운드 시장에서 국 외여행인솔자(TC)는 프리랜서 형태가 일반적이라고 볼 수 있다. 
2000년대 이전엔 굳이 애기하면 이전까지만 해도 어디 소속해서 일하는 분들이 꽤 많았어요. 하지만 지금 은 $A$ 라는 관광통역안내사가 1 부터 8 까지 다른 여행사들한테 고용이 되어있는 그러니까 어떤 여행사에선 우리가 움직일 수 있는 관광통역안내사가 200명이 된다. 역으로 관광통역안내사 입장에서 보면 내가 일하 는 회사도 10 개 20 개도 될 수가 있는 거죠. 그래서 그런 형태로들 많이 일을 해오고 있어서 전에는 종속 관계였다면 지금은 프리랜서 관계로 많이 되어 있습니다.

$\langle\mathrm{B}-10\rangle$

(전속) 가이드가 있는 곳은 세 군데 밖에 없어요. A, B, C 밖에 없어요. 그 곳 외에는 다 자기 가이드가 아니에요. 다 랜드 가이드예요.

$\langle\mathrm{B}-6\rangle$

TC 그분들은 제가 알기로 어느 회사에도 무기계약직이 됐든 소속돼서 된 거는 하나도 없는 걸로 알고 있어요. TC 분들도 전혀 인바운드 가이드보다 더 어떻게 보면 사각지대에 놓여 있다고 볼 수 있겠죠. $\langle\mathrm{B}-4\rangle$

우리나라 인바운드 수요는 중국어하고 일본어 하는 가이드가 대부분이거든요. $90 \%$ 이상 그럴 거라고 알 고 있는데. 인바운드 사업은 많은 여행사들이 아웃바운드는 누구나 다 진행하고 있지만 인바운드는 규모가 큰 여행사만 가능한 사업이거든요. 그러다 보니까 고정적인 단체도 있었고 그러다 보니까 전문적인 우리 회사들을 위해서 열심히 일해 줄 어떻게 보면 그런 인재들이 필요했거든요. 회사마다. 그런 분들이 필요했 기 때문에 그런 분들은 이제 소속을 시켜서 묶었던 거죠. 여러 군데 가지 말고 우리 회사에서만 일해라 하는 형식이죠. 몇몇 회사들은 그런 식으로 무기계약직 식으로 인바운드 가이드는 고용해서 많이 있었을 거예요. 그렇게 유지해왔고. 제가 알기로도 대부분 인바운드 가이드 분들은 거의 다 해지해서...(중략) 저희도 TC들이 있었지만 그분들은 회사에 소속된 계약직 신분 조차 안 됐기 때문에 어떻게 보면 회사에서 아무 신경 안 쓰고 방치된 거죠.

$\langle\mathrm{B}-4\rangle$

관광통역안내사는 2000년대까지 일부 여행사에 소속된 정규직 개념의 고용관계가 존 재했으나 최근에는 대부분 프리랜서로 전환된 것으로 나타났다. 인터뷰 참여자의 대부분 이 관광가이드 직종을 프리랜서 형태로 인식하고 있었다.

저 같은 경우는 들어간 시기가 좋다 보니까 정규직으로 일하게 됐고, 그 때만 해도 들어와서 순차적으로 정규직으로 해 줬기 때문에 정규직 인원이 한 40 명 정도 됐던 것 같아요. 그런데 그 몇 년 후에 회사도 입장을 바꿔서 정규직을 더 이상 뽑지 않고, 프리랜서로 뽑으면서, 이제 회사 입장이 바뀐 거죠. 기존에 정규직이었던 사람들이 퇴사하는 경우가 있잖아요. 개인 사정으로. 그러면서 지금 현재 정규직으로 남아 있는 사람은 11 명이고, 나머지 지금 현재 활동하는 가이드가 50 명 됩니다. 저희 회사만 50 명 되는데, 40명 정도는 여전히 비정규직으로...

$\langle\mathrm{B}-15\rangle$

관광가이드의 근무여건 개선 필요성은 공통된 의견이었다. 무엇보다 힘든 부분은 여 행 중 발생할 수 있는 위험 요소를 가이드 혼자 부담해야 한다는 점이다. 단체여행객을 인솔하여 여행 전체를 책임지는 위치에 있으나, 실제 산재보험 적용 대상에도 포함되지 


\section{않는 열악한 환경에서 근무하는 것이 현실이다.}

지금 상황이 물리적인 게 아니고, 천재지변이다시피 생긴 것이기 때문에, 그거를 어떻게 해결을 해야 될지, 그런데 진짜 열악한 상황에서, 저희 현지에서 일할 때 정말 열악한 상황에서 일하고 있거든요. 일이 많이 있더라도 그래도 예를 들면 교통사고 건이라든지, 안정적인 보수라든지, 그런 부분이 약간 다른 일반 정규 직하고는 좀 다르죠.

$\langle\mathrm{B}-15\rangle$

저희가 사실 가이드 시험 볼 때 쉬운 과목은 아니잖아요. 4 개 과목을 해야 하고 역사도 하고 면접에서 우리나라에 대한 자부심이라든지, 국가에 대한 사명감까지 내세우면서... (실상은) ... $\langle\mathrm{B}-14\rangle$

이번 심층인터뷰에서 관광가이드는 근무 시간이나 형태에서 특수한 형태의 직종으로 고용보험 적용의 한계를 인식하고 있었다. 인터뷰 과정에서 고용보험 뿐 아니라 관광가 이드 직종에 대한 산재보험 적용의 필요성도 언급되었다.

저희가 비성수기가 있잖아요. (중략) 우리가 3, 4, 5월 성수기에 뛰고 6, 7, 8월 비수기에 놀아. 그때 실업 급여 조건은 안돼, 3 개월 일했으니까. 고용보험을 계속 내야 하는데 회사에서도 수입이 없는데 돈을 내줘. 그것도 약간 부당할 거 같다 생각이 들어요. 우리나라 고용보험 체계가 저는 차라리 그냥 협회도 있고 그런데 그래서 등록 가이드를 해서 실제 일을 하고 있다는 것만 증빙이 되면 그거에 대한 부분으로 관광협 회가 하든, 가이드 협회가 하든, 거기서 움직여야 하지 않을까...

$\langle B-14\rangle$

저희가 어디서 무슨 사고를 어떻게 당할지 모르고 버스에서 앉아서 애기 하라고 하지만 저희가 앉아서 애기 할 수 있는 상황은 안 되잖아요. 버스에서 손님들하고 같은 얼굴을 마주보고 애기해야 하는데...(중략) 사고가 나면 손님은 안 다쳐요. 저희는 다치잖아요. $100 \%$, 서 있으니까. 그래서 산재보험은 해야 하지 않을까. 1일 산재보험이라도 일할 때만이라도 해서 교통사고만 아니라 손님 모시고 여기 저기 다니다 보면 저희가 대신 넘어지는 경우도 많고 그런 거는 해줘야 하지 않을까요? (중략) 가이드 일을 하면 가이드만의 실비를 들어줘도 괜찮겠다. 사실 뭐 교통사고도 있지만 식당에서 배탈이 나는 경우도 있고, 병원 가서 입원 하고 그럴 때 실비를 해준다든지. 사망에 대한 보험 이런 사고에 대한 부분을 커버를 할 수 있는 그런 것들을 해주면 좋겠다는 생각이 들더라고요. 특수 직업이잖아요. 이게 저희가 그렇게 따지면 가이드가 더 특수한데.

$\langle\mathrm{B}-14\rangle$

특히, 코로나 19 상황에서 고용의 취약성이 드러나며, 고용보험과 같은 안전망의 필요 성에 공감하는 인식 변화도 나타났다.

제가 작년에(2020년) 여행업을 못하게 되면서 다른 일을 했다고요. 다른 일을 하면서 고용보험은 그게 180 일이 넘어서 올 1월 달에 실업급여를 신청했었어요. 그게 자격이 되어서.. 근데 괜찮더라고요. 이래서 고용보험을 드는구나... 저는 사실 그런 거 하면 낼 의지도 있고 할 건데...

$\langle\mathrm{B}-6\rangle$ 
한편, 매달 수입이 불규칙한 직업 특성 상 매달 정기적으로 납부해야 하는 보험료에 대한 부담감도 언급되었다.

특고 애기해서 고용보험을 이거 뭐 애기만 나오잖아요. 많이 찬성을 하죠. 갑자기 일 터지면 수입이 아무 것도 없으니까.. 그런 거는 저희 입장에서는 반가운데 반가우면서도 사실 불안한 게 그 비용을 우리가 매달 내야 되는 거잖아요? 회사에서 내줄 것도 아닐 것 같고, 내줄 반을... 보통회사처럼 반반 내주면 고마운데 회사에서 내주는지 안 내주는지 모르겠어요. 회사에서 반 내주고 우리가 반 낸다 그러면 다 하죠. 그런데 본인이 다 내야된다 그러면 수입이 없으면 안 낼 사람도 있다고 생각해요. (중략) 매달 3만원, 4만원을 부담스러워 하는 사람들도 있는 거죠.

$\langle\mathrm{B}-6\rangle$

\section{2) 여행업 사각지대 - 대리점/랜드사 등 영세 자영업자}

여행업의 홀세일러와 대리점(전문판매점), 랜드사 등 형태가 다양하다. 소규모 형태로 운영이 가능하기 때문에 자영업자, 무급가족종사자의 비중이 높은 것이 여행업이다.

대리점은 구조가 또 다릅니다. 한 두명이 일합니다. 사각지대라고 말씀드리는게 대표거든요. 종사자가 아 니라 지원을 못받았죠. 그리고 영세자영업자로 분류되지 않아서 초기에 지원 대상이 아닌 사각지대였습니 다. 이 사람들은 자영업자로 지원을 받아야하는데 처음에 조용하다가 같이 시위에 참여했죠. 최근에 이들 도 자영업자로 포함되면서 지원 대상에 포함되었죠. 남편이 사장, 부인이 예약 업무를 담당하는 구조, 1 인 기업, 친인척이 운영하거나, 혼자하거나... 많습니다. 대부분 먹고사는 정도입니다. 집이랑 사무실을 같이 쓰는 형태가 많습니다. 진입장벽이 낮기 때문에 오히려 동네 치킨집보다 영세한 경우도 많습니다.

$\langle\mathrm{B}-1\rangle$

랜드사에 속한 2 3명 단위로 운영되는 일반 대리점 형식의 여행사 종사자도 사각지 대에 놓여 있다. 5 인 미만의 소규모 여행사가 다수를 점하고 있는 여행업의 구조상 필연 적인 결과로 볼 수 있다.

지금 일단 여행사 내에서는 크게 저희 같은 패키지 대형 여행사들에서는 사각지대가 프리랜서 인바운드 아웃바운드 프리랜서를 볼 수 있겠고요. 그렇지 않고서는 대부분의 여행업에 종사하는 많은 분들 중에 우 리가 랜드사라고 하잖아요. 랜드사에 속한 분들이 있을 것이고 2 3명 단위로 운영되는 일반 대리점 형식 의 여행사가 있잖아요. 그런 데 속한 종사자도 꽤 많거든요. 기업 규모가 5 명 2 명 6 명 그런 분들도 이번 기회에 제가 알기로도 아주 소규모의 여행사는 대부분 사업을 정리하든가 사업자등록만 유지 한 채로 있는 직원은 전부 다 정리하고 그렇게 남아 있는 걸로 알고 있습니다. 마찬가지로 사각지대에 놓여 있다고 볼 수 있죠. 저희 같은 이런 중소기업 정도 되는 규모에서는 노동조합도 있고 그리고 근로자 대표가 있어서 조직 할 수 있는 그런 힘이 있지만 2 명 5 명 이런 사업장에서는 이런 것들이 곤란하기 때문에 마찬가지로 고용보험 이런 게 되어 있다 하더라도 사업주의 의지에 따라서 언제고 그만 둬야 되는 그런 상황에 놓여 있다 봅니다.

$\langle\mathrm{B}-4\rangle$ 


\section{3) 여행업 사각지대 - 직무역량 변화로 인한 사각지대}

앞으로의 환경변화에 적응하지 못하는 직무 영역, 예컨대 대리점 영업직, $\mathrm{OP}$, 티켓 발권직 등에서 새로운 고용안전망의 사각지대 발생 가능성이 높다고 보았다. 직무 재교 육을 통해서 효율적인 재배치가 이뤄질 필요가 있다. 재취업이나 재교육이나 전환 배치 나 이런 부분에 대한 것들은 준비와 전략적 대응이 요구된다.

트렌드에 따른 IT 발전이나 모바일에 따라서 특정 직무 분야가 어느 순간 사라질 수 있는, 지금 가장 걱정 되는 게 대리점 영업 사원들이에요. 대리점을 방문 안 하게 되고 과거에는 돈 받으러 다녔는데. 돈 받으러 다닐 필요도 없고 보증보험이 너무 잘되어 있으니까 과거에 100 명이 필요한 게 50 명 필요하고 20 명 필요 하고, 나머지 있었던 80 명 직원들은 허드렛일로 빠지게 되는 거예요. 이분들이 이제 어떻게 보면 고용안전 성에서 어떻게 보면 가장 위험한 군으로 분류가 되는거죠. $\langle\mathrm{B}-3\rangle$

\section{라. 향후 전망}

코로나19 이후 FIT로 시장의 전환, OTA의 영향력 강화 등으로 기존 여행사의 역할 이 축소될 것이라는 우려가 크게 나타났다. 여행업의 구조 변화로 새로운 직무 요구에 따른 종사자, 인력 대응이 시급한 상황이다. 환경변화에 대응하는 새로운 인력 수요와 기존 인력 활용의 균형점을 찾는 것이 필요하다.

여행은 계속되지만 여행업은 없어질 것이다라는 생각을 합니다. 산업의 구조조정이 필요합니다. 그래야 산업을 살리고, 새로운 일자리를 만들고, 경쟁력을 갖출 수 있다고 생각합니다.

여행업의 수익구조를 만들어야 합니다. 지금은 너무 빈약해요. 여행사가 수익이 없어요. 진입장벽이 낮으 니까 너도나도 들어오고, 경쟁력은 없고.. 가격으로 경쟁하고. 항공권 판매하면 돈이 안남아요. 여행상품은 공짜죠. 항공권 판매에 대해 상품, 환불에 대한 수수료를 받아야 합니다. 외국은 다 그렇게 합니다. 시간당 상담시... 변호사는 컨설턴트에게 상담을 받으면 그에 따른 수수료를 내야 하는거죠. 전문지식을 제공하는 것이므로 그에 대한 서비스료를 내야 하는 게 맞죠.

$\langle\mathrm{B}-1\rangle$

구조적으로 산업 자체가... 여행업이 중개업이다보니, 최근 온라인의 가속화 등으로 중개업의 설자리가 점 차 줄어들고, 온라인으로 대체되고 있습니다.

$\langle\mathrm{B}-1\rangle$

저희는 여행업은 앞으로 사양 사업이 되지 않을까 우려를 하고 있고요. 이건 단순히 고용적인 측면에서 말씀 드리는 거고요. 지금도 그렇게 변하고 있지만 앞으로 더 그렇게 될 거라고 보는데, 기존에는 우리가 여행업 내에서도 항공 발권을 한다든가 이런 건 약간의 기술이 필요한 분야였거든요. 많은 수요가 필요로 하고 그렇게 됐었는데, 현재는 이런 시스템이 개발되면서 항공을 발권하고 이런 인원도 더 필요 없게 되고 요. 모든 것이 호텔 항공 개인이 인터넷으로 구매하고 할 수 있잖아요. 여행사 역할이 점점 줄어들고 있고 지금 여행사의 추세는 플랫폼 여행사로 변경되고 있거든요. 네이버, 다음처럼 여행 시장에서 00 관광이면 
큰 브랜드를 유지하면서 모든 중소 여행사들이 우리 회사에다 자기 상품을 올려서 판매하게 하는 걸 구축 하려고 하고 있기 때문에 그런 것들이 정착이 되면 대기업에서 손을 대든 기존에 어떤 몇 개 우수 업체가 하든 해서 그렇게 아마 재편이 될 것이다. 중소 여행사들이 아주 특화 되어 있지 않으면 줄어들 것이고, 거기에 따라서 필요한 인력도 더 줄어들 것이다 고용 측면에서 봤을 때 앞으로 여행업을 하고자 하는 그런 희망하는 그런 취업 희망 준비생한테는 사양사업이지 않나 예상을 하고 있습니다.

$\langle\mathrm{B}-4\rangle$

이 사람들의 여행 중개업자들의 더 많은 큰 목소를 내는 사람들이 우리 먹고 살게 해달라.. 변화를 인정하 지 않는 사람들의 목소리가 크기 때문에 어떻게 유지시키면서.. 전환을 유도할 것인가가 균형있게 가야합 니다. 이 사람들, 우는 사람들이 소규모 대리점업자들이 많고.. 이게 한계입니다. 이들의 전환 모델을 정책 적으로 고민해야 합니다. 사실 여행업 내부적으로 기존 모델은 힘들다는 걸 다 압니다. 이미 0000 는 구조 조정을 완료했고 0000 도 곧 구조조정 할 겁니다. 이대로 안된다는 인식이 팽배합니다. 0000 가 소사장제 로 간다는 발표인데.. 결국 구조조정을 의미합니다. 핵심기능만 남겨두고, 나머지는 자회사로 나누는거죠. 근데 자회사로 분리되는 영역에서는 돈을 벌 수 없습니다. 그나마 할 수 있을 때 버리는 거죠. 아직은 패키지 시장이 있거든요. 근데 미래에는 그게 안보이죠.

$\langle\mathrm{B}-1\rangle$

\section{3. 심층인터뷰 결과: 관광숙박업(호텔업, 휴양콘도미니엄업)}

\section{가. 노동시장 및 직무 특성}

호텔은 다양한 직무가 복합적으로 나타난다. 호텔이라는 공간 안에 프론트, 하우스키 핑, 미화, 식음, 시설 관리, 마케팅 세일, 경영, 재경 등 다양한 직무에서 일하는 사람이 존재한다.

호텔이 굉장히 재미있는데요. 한 건물 안에 엄청나게 많은 직무가 존재합니다. 같은 건물에 이렇게 다양한 직무가 근무하는 공간이 없을 겁니다. 호텔의 얼굴인 프론트, 객실 정비하는 하우스키핑, 퍼블릭이라고 하는 미화, 식음료(홀, 주방 담당), 시설 관리, 마케팅 세일즈 등 영업부서, 경영지원, 인사, 총무, 구매, 재경 파트 정도인데... 다양한 직무가 있기 때문에

$\langle A-5\rangle$

호텔산업이 크게 남는 사업이 아니라는 거죠. (중략) 호텔만으로 절대 돈을 벌 수 있는 사업이 아니라는 거죠. 너무 인력 집약적(노동집약적) 산업이다 보니까 인건비가 저희 회사는 인건비가 $40 \%$ 를 육박하기 시작하거든요. (중략) 호텔산업 자체가 경영진한테 굉장히 매력적이지 않죠. 그래서 직원을 줄이기에 급급 하고 직원들을 베테랑 보다는 젊은 직원으로, 업무를 계속 표준화시키려고 하는데, 그래서 그런지 젊은 직원들은 표준화 되는 직무에 대해서 굉장히 꿈을 가지고 왔다가 미래가 없다고 판단하고 빨리 그만 두고 나가는 직원이 많아졌죠.

$\langle\mathrm{A}-3\rangle$ 
호텔업 노동시장은 종사자 연령대가 낮아지고, 장기근속이 어려운 업종이다. 특급호 텔에서 45세 이상은 고령으로 분류되며, 정년퇴직자의 비율이 매우 낮은 업종으로 인식 하였다. 인터뷰 과정에서 서울 지역의 4 5성급 호텔은 이미 코로나19 이전 정리해고 등을 통해 인력구조 재조정이 완료된 경우도 언급되었다.

아주 오래된 호텔 중에 대표적으로 00 호텔, 000 호텔은 구조조정을 다 해서 45살 이상이 많이 없습니다. 아주 높은 관리자를 빼고는...(중략) 신입사원으로 입사를 해서 아주 낮은 단계부터 올라가서 하긴 합니다 만, 직업에 대한 전문성을 인정 받지 못하는 것도 있고, 그 다음에 사회적으로도 그렇고 기업주가 젊은 사람을 원해요. 경력이 쌓이면 퇴사를 할 수 밖에 없는 구조가 되죠. (중략)

서비스업 자체가 조리부든 식음료부든 객실부든 젊은 사람들이 서비스를 해야 한다. 젊은 사람들한테 서비 스를 받고 있다 이런 인식이 있고 해서 전문성에 대한 인정도 많이 부족하고, 사회적으로나 기업주가, 고객 들도 그렇고, (중략) 경력이 쌓인다는 건 상대적으로 고액 연봉이 될 테고, 상대적으로 그런 사람들은 크게 많이 필요 없다 해서 5성급 호텔을 포함해서 정년 퇴직률이 매우 낮습니다.

$\langle A-1\rangle$

호텔 서비스 업무의 표준화, 개인의 경력과 역량보다는 매뉴얼화, 개인의 업무 스킬을 전문적 기술로 인정하지 않는다는 것이다. 호텔 서비스업의 전문성 약화는 보수체계로 이어진다.

젊은 직원들이 와서 그다지 미래가 없다고 생각하고 빨리 빨리 그만두고 그 직원들은 밖에 나가면 기회가 너무 많으니까 전문성을 인정 안 해주는 추세죠. 요즘 호텔은 개인의 업무 스킬을 기술로 절대 인정하지 않는 경우가 많죠, 특히 대기업은. 그러다 보니까 급여 수준이 굉장히 낮아졌습니다. 저희가 아까 말씀 드린 평균 연봉이 00 만원이라고 했잖아요. 그 직원들이 보통 15 년차. 그러니까 굉장히 힘든 구조죠. 어떻 게 보면 15 년이 되어야 평균을 받는 건 좋은 건 아닌 거 같아요.

$\langle\mathrm{A}-3\rangle$

저는 일반적인 상황에서 말씀 드리자면 저는 95 년도에 입사를 했는데요. 입사 할 때만 해도 다른 제 친구 들 2년제든 4년제든 나온 친구들이 비해서 급여가 낮지 않았어요. 호텔리어 괜찮았습니다. 낮지 않은 수준 이었는데, 해가 갈수록 이제 점점 낮아지는 거죠. 상대적으로, 그래서 오래 근무하는 경력은 쌓이는데 급여 는 상대적으로 낮게 평가가 되는 거고...

$\langle\mathrm{A}-1\rangle$

사실은 예전에는 호텔 산업의 종사자들의 연봉이 적은 편은 아니었어요. 들어와서 정년이나 어느 정보 보 장되고 하는 영역이었는데, 이제 가면 갈수록 비정규직화가 많아졌고 이 산업의 전문성에 대해서 인정을 많이 안 해주는 편입니다.

$\langle\mathrm{A}-3\rangle$ 


\section{나. 코로나19 이후 일자리 위기 상황 및 주요 이슈}

호텔업 역시 코로나 19 의 영향으로 휴직, 퇴사, 정리해고 등 고용 관련 문제가 심각한 것으로 나타났다. 고용유지지원금을 통해 휴직을 진행하고 있으며, 코로나19의 장기화 로 국제관광의 정상화 시점이 불투명한 상황에서 고용 유지에 대한 우려가 제기되었다.

(저희는) 휴직을 진행하고 있고, 정리해고는 아주 특수한 경우에만 진행될 수 밖에 없는데... 사실 휴직은 고용을 유지하기 위한 거니까, 저희는 대다수 직원은 휴직을 유도하고, 예외적인 경우 명예퇴직을 진행했 습니다. 작년 3월에 결정되었는데, 고용유지지원금을 $90 \%$ 까지 높여서 240 일 지원했어요. 인건비 부담의 상당 부분을 지원받고 있어요. 엄청나게 큰 도움을 받은 거죠.

$\langle A-5\rangle$

저희는 작년 3월부터 코로나가 본격적으로 시작했다 보고 있거든요. 유급휴직을 제일 먼저 실시했고요. 총 9 개월을 갔었습니다. 원래 나라에서 해주는 6 개월, 특별고용업종 지정하면서 3 개월을 더 가게 됐고요. 직원들은 평균 인당 3 개월 정도 갔다고 보면 될 거 같아요. 그러면서 거의 직원들이 3 개월 동안 $70 \%$ 월급을 받았겠죠. 무급도 한 달을 실시했어요. 일주일에 하루 정도. (중략) 계산해 보니까 직원들 평균 연 봉이 1,100 만원에서 1,200 만원 가량 줄었더라고요. 이게 저희 같은 서민들, 이런 일반 노동자한테는 1 년 에 천만 원이 넘게 줄어든다고 하면 생활비의 $1 / 5$ 이상 날아가는 거니까 타격이 굉장히 컸었죠.

이번에 희망퇴직을 많이 했어요. 물론 회사 돈을 푼 것도 있고 체질 개선을 위해서...(중략) 직원들이 많이 나갔어요. 특히 젊은 직원들. 반반인 거 같아요. 완전 젊은 직원들은 자의적으로 나가는 거고 나이가 있으 신 분은 희망퇴직을 해서 목돈을 가지고 나가는 분들이 있었고. 그래서 저희가 직원들이 너무 많이 그만두 다 보니까 작년부터 시작해서 올해 같은 경우는 어쩔 수 없이 채용까지 할 정도였으니까. $\langle A-3\rangle$

제가 소속된 호텔의 예를 들자면 지금 최근 상황은 작년 10월까지 고용유지지원금을 받으면서 있다가 10 월 한 달을 남겨두고, 호텔에서 다시 출근을 다 시키고, 그리고 정리해고 수순이죠. 희망퇴직을 받으면서 당시 120 명 정도 되는 사람들 중에 45 명 가까이 희망퇴직을 했어요. 작년 12 월에 했고, $\langle A-2\rangle$

100 개 호텔을 비교하고 있는데, 인건비가 $20 \%$ 빠졌더라고요. 처우는 더 어려워지지 않을까... 실제로 작년에는 고용유지 조치 호텔이 상당히 많았는데, 올해는 무급휴직을 한두달 하는 걸로, 직원들이 나눠서 하는 걸로. 작년보다 고용유지 조치가 줄어들 것 같습니다. 지원금이 $90 \%$ 를 다 받는 게 아니거든요. 일일 7만원이에요. 한달에 210 만원이에요. 작년이 아니라 올해가 문제입니다.

$\langle A-6\rangle$

코로나 이후 숙박업 노동시장에서 정규직의 비정규직화와 외주화 추세는 더욱 심화될 것으로 예상하였다.

2010년에 거의 200명 가까이 정규직 형태로 있다가 지금 10 년 동안 거의 반 이상 정규직이 줄고, 무기계 약이나 무기계약직 형태나 외주화 되는 과정에서.. 이제 주차장이라든지 객실 어텐던트, 객실 룸 메이드 분들이 일부 용역화 되면서 하청 구조로 바뀌기 시작했고, 현재는 10년 전에 200 명 이상 되던 정규직이 지금은 60 명 정도 밖에 남지 않아요.

$\langle\mathrm{A}-2\rangle$ 
이마저도 회사는 더 줄이겠다고 정리해고 운운 애기를 하고 있는 상태고요. 최근 저희 호텔은 거의 10 년 이상 동안 고용의 질이 말씀 드렸다시피 하청 부서를 계속 하청 구조로 변화 시킨다든지, 고용 자체를 그 이후에 2012년 4월달인가... 그때 정규직 형태로 3명이 정규직 된 이후에는 정규직 형태로 된 사람 아무도 없고. 작년 무기계약직 형태로 고용이 되다가 실질적으로 작년에 11월달에도 무기계약 형태로 있 던 직원 대부분이 희망 퇴직 같이 나가버렸어요. 그만큼 호텔 내에서 상대적으로 젊고 입사 한 지 얼마 안 된 동료들이 미래를 못 보는 거죠. 너무 열악하고 임금 이런 것도 열악하고 미래 희망을 가질만한 그런 부분들에 대해서 많이 적고 하다 보니까 무기계약직이라는 이런 어쨌든 약간 임금에 포함된 형태가 12 시 간 연장이 포함되어 있고 처음에는 야간 10 시간 휴일 8 시간 포함을 다 시켜서 임금을 하다 보니까 거의 최저임금 약간 넘는 수준의 임금에서 고용이 되고, 정작 근무는 실제 12 월 달 전후로 하는 성수기에는 60 시간 70시간 훌쩍 넘어가는 것이 대부분인데도, 임금들이 너무 장시간 노동을 통해서야만 겨우 생활 임금 정도를 받을 수 있는 수준이다 보니까 고용의 형태는 계속 이런 식으로 질이 계속 나빠지고, 실제 주방은 조리 같은 경우에는 60 세 넘으신 은퇴 하신 분들을 고용해서 몇 개월씩 고용하는 그런 형태까지 이런 부분들이 지속되다 보니까 저희 호텔 상황은 이렇게 거기에다가 객실 같은 경우에는 아예 하청 형태 의 구조가 되다 보니까 작년 12 월까지 남아 계신 정규직 분들이 대부분 퇴직하고, 두 분 남으신 분이 주방 으로 전환 배치되고, 그러면서 $100 \%$ 하청이 되어 버렸죠. 그러면서 지금 코로나 상황에 아예 그냥 거의 3 번 출근을 하시면서 일하시는, 물론 코로나 때문에 어렵긴 하지만, 고용 자체는 거의 벼랑 끝에 와 있다 고 생각하고 있습니다.

$\langle\mathrm{A}-2\rangle$

\section{다. 고용안전망 사각지대 및 실태}

\section{1) 숙박업 사각지대_외주 협력업체}

숙박업의 고용안전망 사각지대는 호텔·리조트 운영에서 최근 확대되는 외주화에 따른 협력업체 소속 노동자가 대표적이다. 호텔의 외주화는 객실 하우스키핑 뿐 아니라 주차

장, 시설 관리 등 외부 위탁용역 전환 범위가 확대되는 추세이다.

외주가 많이 됐죠. 1995 년에 저희가 상시 비상시 다 합해서 800여명 정도 근무를 하고 있었단 말이죠. 2019 년을 보면 700 여명이 근무하고 있어요. 100명 차이란 말이죠. 20년이 지났음에도 불구하고, 그 내용을 보면 정규직이 95년도에는 약 700여명이 됐고요. 2019년에는 정규직이 430명이니까 주로 간접 고용이나 외주 협력사, 용역 이렇게 구성이 되어 있는 거죠.

$\langle\mathrm{A}-1\rangle$

요즘 호텔들마다 고민이 예약을 받아주는 예약이나 우리가 전문 용어로 000 라고 해서 손님들 안내해주거 나 이런 직원들이 있거든요. 예약실을 외주화 하는 경우가 많아요. (중략) 00000 는 조리사들이 다 외주 직원이에요, 조리사나 식음장이 다 외주였거든요. 그런데 이런 제가 봤을 때는 이런 직무에 대해서 계속 외주화가 된다면 결국 호텔의 경쟁력이 떨어지고 그러다 보면 당연히 남아 있는 정규직들까지 어려워지겠 죠.

$\langle\mathrm{A}-3\rangle$

정직원이 980 명 정도 되고요. 저희 아웃소싱 직원들이 600 명 되고요. $\langle\mathrm{A}-3\rangle$ 
코로나19 이후 호텔의 위탁용역은 계약을 종료하거나 규모를 축소 운영하는 것으로 나타났다. 계약이 유지된 경우도 코로나 19 로 도급비 등이 축소 운영되고 있는 상황으로, 이러한 협력업체 소속 근로자를 대표적인 고용안전망의 사각지대로 언급하였다.

이건 호텔의 갑질일 수 있는데, 도급 계약은 1 2년으로 하는데, 호텔이 문을 닫으니까. 메이드는 일자리, 사업장이 없어졌는데. 호텔은 고용유지 지원금을 받는데, 도급은 해당이 안되는거죠. 호텔업이 아니라는 이유로. 처음에. 지금은 포함된 것으로 압니다. 이분들이 실업급여로 권고사직 처리가 되었는데, 호텔의 유관업종으로 등록되어 있었다면 처음부터 실업급여가 아닌 고용유지지원금을 받을 수 있었다는 거죠. $\langle\mathrm{A}-5\rangle$

제일 쉽게 애기하면 협력사 업체들 중에 대부분은 계약을 안 했죠. 통상 1년 계약을 하니까, 1 년 계약인데 작년은 협력사 절반 정도를 계약을 안 했습니다. 그래서 물론 하우스키핑을 완전 없앴겠죠. 거의. 주말에 알바를 부르는 한이 있더라도 협력사 계약을 안 했죠. 초반에. 그래서 협력사들이 굉장히 줄었고. 올해 같은 경우는 그래도 작년보다는 조금 높게 계약을 한 형태인데, 올해도 뭐 2019년도에 비하면 거의 절반 수준이죠. 인원 수로 말씀 드릴 수 밖에 없는 거 같아요. 인원 수가 엄청 많이 줄었죠. 협력사 분들 진짜 많았을 때는 호텔이 저희가 두 개거든요. 거의 1,200 명 가까이 쓴 적도 있었어요. 협력사 분들. $\langle A-3\rangle$

호텔의 협력업체는 호텔업과 달리 정부의 코로나 19 대응 특별고용지원업종에 해당하 지 않아 고용유지지원금의 혜택 또한 받을 수 없는 상황으로 경영악화를 극복할 수 있는 지원방안 모색이 필요한 상황이다.

경제사회노동위원회에서 호텔업을 대상으로 실시한 조사에서도 협력업체 중 하우스 키핑과 같이 인력공급업체를 운영하고 있는 기업들은 대부분 근로자 수가 많고, 매출액 이 일정 범위 이상에 해당하여 고용유지지원금 대상에서 제외된 것으로 나타났다.

\section{2) 숙박업 사각지대_일일노동자 \& 초단시간 근무자}

숙박업은 계절성, 성비수기, 대규모 집객시설의 운영 등 그 특성상 임시직, 일용직 등 비정규직 인력 활용이 활발하다. 숙박업의 비정규직은 단기 알바, 초단기 근로 등 임시. 일용직의 근무 형태가 다양하게 나타난다. 일용직 근무자는 직접 아르바이트 모집 공고 를 통해 운영하거나 외부 대행업체를 통해 모집이 이루어진다.

고용형태로 보면 정규직, 일용직, 도급직이나 전부 고용보험 의무가입입니다. 사각지대라고 하면, 주중 알 바, 주말 알바. 주중 알바는 주 15 시간 미만이 있어요. 고용보험 가입 안하고, 세금도 안내고... 그런 부분 이 있거든요. 초단기 근로자들인데...

$\langle A-5\rangle$ 
저희는 무조건 비정규직은 다 업체를 통해서 하는데요. (중략) 청소하시는 근로자 분들 특별히 기술은 필요 없는데 사람 손이 필요한 주차 관리 요원 이런 사람들 있잖아요, 그런 분들은 굉장히 왔다 갔다 하죠. 회사의 경영 상황에 따라서... 특히 저희는 유일하게 고객을 대면하는데 아르바이트 파트타이머가 오는 곳은 식음 $\mathrm{F} \& \mathrm{~B}$ 쪽에 연회장 직원이 그렇거든요. 연회장은 주말에, 주말은 저희 연회장만 양쪽 연회장으로 한 100 명 가까이 아르바이트가 왔어요, 지금 거의 안 오겠죠. 그리고 $\mathrm{F} \& \mathrm{~B}$ 는 대체도 가능하잖아요. 휠씬 많이 줄었죠.

$\langle\mathrm{A}-3\rangle$

호텔업과 휴양콘도미니엄업의 경우, 연회 등은 수요의 불규칙하여 상시적으로 필요한 인력이 아니기 때문에 단기 아르바이트 인력 활용이 일반적이다.

아까 말씀 드렸지만 정규직 외에 직원들은 비정규직 분들은 코로나 이전이랑 코로나랑 마찬가지 같아요. 고용 형태는 대부분이 아르바이트 입니다. 대부분 다 최저임금의 아르바이트 하시는 분들이고, 코로나 이 전에 호텔이 계속 잘 됐을 때는 아르바이트를 쭉 할 수 있었다는 거, 최저임금이 올라가는 만큼 할 수 있었지만, 저희도 코로나는 처음 겪어 보는 상황이잖아요. 이게. 절대 안정 될 수가 없죠. 그분들은. 그분 들은 이제 필요가 없으면 안 나오고 나오지 말라고 하면 그만이니까. $\langle A-3\rangle$

연회, 결혼식은 고급인력이 그렇게 많이 필요하지 않거든요. 그리고 상시적으로 필요한 인력이 아니기 때 문에 아주 시즌에만 성수기에만 결혼식 성수기, 연회 성수기 이럴 때만 사용하기 때문에...

$\langle A-1\rangle$

특히 리조트 등 휴양콘도미니엄의 경우, 성비수기 계절성으로 인한 아르바이트 인력 활용, 겨울-스키장, 여름워터파크 등 계절 수요에 대응한 한시적 인력 활용이 이루어진 다. 계절 수요의 영향을 받는 강원 등 지역에서는 단기 인력 수급에 어려움이 많은 것으 로 나타났다.

외주화 영역이 점차 증가하는 것은 여러모로 우려되는 상황이지요. 저희 업장 케이블카도 운전자는 정규직 인데, 케이블카 내부 청소, 입구의 안전 관리자 등은 협력사 직원이 담당하고 있어요. 대체로 중요한 업무 는 정규직을 배치하고, 정규직이 협력사 직원에 대한 관리자 역할을 하는 것이죠. 그래서 정규직하고 협력 사 직원 사이의 갈등이 심해지고 있습니다. 서로간의 책임 회피나 업무량의 형평성 등이 문제이죠. $\langle\mathrm{A}-4\rangle$

중소호텔의 경우 임시직 형태로 고정적인 인력, 소위 '장기 알바' 인력을 활용하는 경 우도 있었다. 장기 알바인력은 정규직을 지원하는 역할을 담당하며, 직원 수준의 시간 근무와 노동 강도에서 근무하는 경우도 나타났다. 
(4대보험) 그런 거 적용 안 시키죠. 당연히, 왜냐하면 4대보험 적용 하면 실질적으로 고용이잖아요. 어떤 식으로 하냐 하면 직접적으로 전화해서 부르는 사람이 있고, 직업소개소 통해서 하는 사람이 많아요. 보통 3 4군데 업체를 통해서 주말이나 행사가 주말 쪽에 몰리고 주중에는 그냥 웬만큼 있는 행사는 했으니까, 코로나 이전에는 주중 주말 할 때 좀 편법 형태로 그런 식으로 많이 고용했었죠. 그런 식으로, 장기 알바는 거의 직원 수준의 시간이나 노동들 다 했거든요.

$\langle A-2\rangle$

\section{3) 숙박업 사각지대_65세 이상 재취업 인력}

최근 숙박업에서는 65세 이상의 실버인력 활용, 재취업 인력 활용이 이루어지는데. 이들은 고용보험 가입 대상에서 제외되어 코로나19 상황에서 대부분 실직하고, 실업급 여도 받지 못한 것으로 나타났다.

호텔이 실버인력의 재취업이 활발한 곳인데. 호텔 관리자로 있다가 퇴사하고, 미화반장으로 오실 수도 있 는데, 만 65세 이후에 입사를 했다가... 이번에 코로나로 실업급여를 받고 싶어서 권고사직을 진행했는데 알고 보니까 실업급여 대상이 아니더라고요. 메이드도 그렇고 나이 든 분들이 있으신데.. 관련된 나이체계 가 조정되어야하지 않을까. 65 세가 요즘은 충분히 경제활동이 가능한 나이거든요. 실버의 고용보험 가입 이 되어야 보장받을 수 있고. (중략) 호텔은 통상 60 세 이상을 실버로 봅니다. 남성은 시설 관리에 재취업 하거나, 여성은 미화나 하우스키핑에 재취업하는 경우가 많으세요. $\langle A-5\rangle$ 


\section{4. 심층인터뷰 결과: 국제회의기획업(PCO)}

\section{가. 노동시장 및 직무 특성}

PCO 종사자는 현장에서 요구되는 역할과 전문성에 비하여 보수는 열악한 업종으로 인식하였다. 지난 10 년간 컨벤션 산업이 성장해왔으나 종사자에 대한 처우는 크게 개선 되지 않은 것으로 나타났다. 직무가 대행업, 대행 업무를 담당한다는 데에서 나타나는 근무시간의 불규칙, 야근, 갑질 등 업계의 풍토는 종사자가 이직을 고민하게 한다.

사실 제가 이제 PCO 만으로 한 거는 7 8년 된 거 같고, 호텔에서 하면 10년 정도 된 거 같은데, 사실 아직 10년차 11년차라고 해도 아직도 제가 이 업을 하는 것이 맞나 생각을 사실 그런 고민을 꾸준히 하고 있고요. 그 고민의 가장 큰 이유 중에 하나는 어쨌든 제가 받는 보수 대비 업계가 바라는 것들이 많지 않나 그런 불일치함 때문에도 있고, 그리고 제가 어쨌든 이게 한 10년 정도를 봐 왔는데, 10년 전에도 MICE 산업이 고부가가치를 이끌어내는 발전 가능한 이런 산업이었는데, 제가 체감하기에 10년 사이에 조금 업그레이드 됐다. 인식이 더 좋아졌다라는 느낌보다는 오히려 이제 이런 업체들도 너무 많이 생기고, 대행이라는 단어에 갇혀서 대행업, 대신해주는 사람이라는 그런 관점들을 받다 보니까, 일을 하면서도 자 신감이 떨어지거나 그런 부분이 있었어요. 그래서 그거 때문에 딜레마가 있는 거죠. 이게 분명히 나는 멋있 는 직업이고, 노력을 해서 여기까지 온 건데 시간이 지나도 바뀌는 거 같지 않고 그래서 조금 또 이직을 생각하게 되고, 그리고 이제 밑에서 1년차 2년차 다른 친구들한테도 너무 좋아, 몇 년만 견디면 괜찮아 라고 하고 싶은데, 같이 야근을 하고 있고 7시 8시 클라이언트가 문의를 하고 바꿔 달라고 하면 저도 어쩔 수 없이 안 됩니다라고 표현하기 어려우니까 미안하니까 오늘 같이 해주자 이런 상황이 반복되니까 그런 부분들이 사실 제 이직이나 아니면 다른 사람들 이직에 좀 영향을 미치지 않았을까 싶습니다. $\langle\mathrm{C}-3\rangle$

우리는 아직 소규모고 중소기업이니까 이해해줘. 우리는 많이 주는 편이야. 이렇게 생각하는 거 자체가 개선의 여지가 저는 없다고 판단을 하거든요. 그래서 스튜어디스처럼 전문적인 서비스직을 바라고 계시고, 저희가 통번역사는 아니지만 그런 정도라고 하면 그런 전문성이 있는 업체들과 비교해서 우리 업계 인건비 는 어느 정도 인가 비교해야 하는데, 비교는 항상 그냥 사물 행정 하는 중소기업 업체들과 비교를 하다 보니 조금 더 많을 수 있겠죠. (중략) 전문직이라고 애기하고 싶으면 급여적인 부분도 좀 더 전문직과 비교해서 주면 사람들도 어떻게 해서든 더 노력을 해서 남아 있을 것이고. 좀 더 자기 커리어를 위해서라 도 경력이든 실력이든 학력이든 쌓으려고 하지 않을까 개인적으로 생각했습니다.

$\langle\mathrm{C}-3\rangle$

노동시장에서 높은 업무강도와 낮은 보상체계가 반복되고 있으나, 종사자의 근로환경 개선을 위하여 파트너로서 공존하는 방법, 번아웃 방지, 워라밸(Work-Life Balance) 추구 등을 고민하는 것으로 나타났다.

아무래도 이런 야근이라든가, (클라이언트의) 갑질에 대해서 어떤 식으로 대처를 하고 우리도 어떤 식으로 파트너 사로서 공존을 할 것인가 이런 고민들을 저희 세대 저희 윗세대도 많이 하고 있다고 생각을 하는데 요. 그러면서 조금씩 문화를 바꿔가려고 하고, 워라밸도 지켜 가려고 하고 일에 지쳐서 번아웃 돼서 나가 떨어지는 걸 최대한 방지 하려고 하는 거 같은데, 사실 그게 얼마나 잘되고 있는지 의문스럽습니다. $\langle\mathrm{C}-3\rangle$ 
고부가가치 산업이라고 MICE 산업 컨벤션 산업 많이 이야기 하는데, 사실은 우리가 해외랑 업무를 하고 여러 업무를 하다 보면, 명찰을 칼로 잘라서 가나다 순으로 맞춰서 끼워 넣는 작업부터 어떤 긴급 자료 나오면 복사해서 스테플러로 찍고 이런 정말 단순한 그런 업무들도 상당 부분이 있고, 그런 부분이 상당히 많이 있다 보니까 결국에 $\mathrm{PCO}$ 를 기피한다고 할까요? 많이 우리가 듣는 애기가 업무가 과중하고 박봉이다 라고 하는데, 사실 그런 생산성이 낮은 업무들도 우리 업무의 상당 부분이 있다는 거죠. 그런 상당 부분이 있다 보니까, 당연히 생산성이 낮은 업무다 보니까 그거에 대해서 어떤 충분한 대가를 보상하기 어려운 구조이고, 이러한 과중한 노동, 낮은 생산성, 낮은 보상, 이런 것들이 반복되는 악순환의 고리가 있지 않나 생각을 하고 있고요.

$\langle\mathrm{C}-2\rangle$

컨벤션 업계는 근무경력, 프로젝트 규모에 따른 역할과 경험이 축적될수록 종사자의 전문성을 인정받는 근거가 된다.

우리가 자신만의 레퍼런스나 어떤 전문성이 없다면 이 업계에서 살아남기가 어려운 부분들인 거 같고요. 개인적인 입장에서 제 개인의 입장은 아니지만, 제가 주변에 종사 하시는 분들의 입장을 근로자 분들 입장 을 본다면 어떤 프로젝트에서 어떤 역할을 했는지에 대한 것들이 본인의 경력으로 가장 크게 (인정)됩니다. 우리나라에서 개최 되었던 어떤 회의들에서 어떤 역할을 했고, 그런 것들이 가장 큰 개인 경력의 이슈가 되는 거 같고 $\langle\mathrm{C}-2\rangle$

\section{나. 코로나19 이후 일자리 위기 상황 및 주요 이슈}

국제회의기획업은 정부의 코로나19 특별고용지원업종 지원 대상에서 초기에는 제외 되고, 지원대상이 확대되면서 포함되었다. 실제 업계는 코로나19로 폐업, 휴업 사례가 발생하고 있으며, 이 과정에서 정부의 고용유지지원금은 종사자의 고용 유지에 상당 부 분 기여한 것으로 판단된다.

고용지원금 제도가 사실 지금 제 주변에도 이렇게 안타깝게 폐업을 하신 분들도 있고 사실 사업자는 유지 가 되었지만 사실상 폐업을 하신 분들도 있고, 사실 사업자는 유지가 되었지만 사실상 폐업 그래서 투잡 뛰시는 분도 있고 그런 분들도 있지만 고용지원금 제도, 고용유지 지원제도가 상당히 많은 도움이 됐습니 다. 아마 몇 개월 동안 휴직을 하고 그러면 국가에서 $70 ~ 80 \%$ 의 급여를 지급을 하고 사업자는 이렇게 어떻게 하고 이런 제도들이 있었는데, 그런 것들이 사실 되게 많은 안전망이 되어서 직원들을 정리하지 않고 유지할 수 있는 좀 도움이 많이 됐던 거 같아요.

$\langle\mathrm{C}-2\rangle$

고용유지지원제도 적용시 업종의 특성에 대한 고려도 언급하였다. 사업주 입장에서의 난제는 프로젝트 준비에 상당한 시간이 소요되는 업종 특성 상 후년도 사업계획을 당해 연도에 준비해야 하는 점에서 종사자의 휴직으로 인한 어려움을 토로하기도 하였다. 
그게 어떻게 보면 휴직을 할 때 국가가 지원을 해준다는 거였거든요, 그러면 직원들은 다 쉬어야지 국가가 지원을 해주잖아요. 저희는 입찰에 들어가거나 어떤 제안서를 쓰거나 영업을 한다고 해도 어떤 저희가 어 떻게 하겠습니다라는 제안서를 제출을 해서 그게 보통 비딩을 통해서 수주를 하는 경우가 많은데 사실 다 휴직을 해야 지만 지원을 해준다고 했을 때는 그러면 우리가 언젠가 다시 재개하기 위해서는 직원들이 나와서 제안서도 쓰고 뭐도 하고 이러한 기반을 닦아야 하는데, 그것들을 막는 거예요. 그러다 보니까 그러 면 갑자기 코로나가 극복된다고 해도 일이 뚝 떨어지는 건 아닐 텐데, 그랬을 때는 이 부분들은 어떻게 하지? 라는 부분들은 되게 좀 어려움이 있었었죠. 그래서 어떻게 보면 직원들 주변 회사들만 봐도 직원들 은 다 쉬고 막 대표님이나 팀장들 이런 정말 좀 회사의 로열티를 가지고 계신 분들만 오히려 나와서 일을 제안서 쓰고 이런 경우를 많이 봤었는데, 국가적인 측면, 큰 차원에서 보면 사실 이런 휴직 기간에 대한 보상금을 주는 거기 때문에 이 제도의 취지 자체는 충분히 공감하고 있지만 저희 입장에서는 사실은 그러 면 언제 어떻게 이 친구들 다 쉬면 언제 일 가지고 와? 이런 생각을 할 수 밖에 없었죠.

$\langle\mathrm{C}-2\rangle$

\section{다. 고용안전망 사각지대 및 실태}

\section{1) PCO 사각지대_프리랜서}

PCO 업계는 프리랜서 인력 활용이 활발한 것으로 나타났다. PCO 분야의 프리랜서 는 대부분 업계 경력직으로, 사실상 자발적 프리랜서에 가까운 것으로 판단된다.

프리랜서는 사실 되게 많은데요. 프리랜서를 할 수 있다는 것이 한 행사에서 분과를 떼서 맡길 수 있을 정도, 그러니까 한 2 3년 차가 되거나 아니면 행사 하나의 PM을 할 수 있을 정도 급들을 보통 뽑고요. 아니면 정말 계약직으로 인턴처럼 뽑는데, 제 주변에는 이제 이런 야근도 많이 하고 조직에 속해 있다 보면 저희가 아무리 신생업체라고 해도 $100 \%$ 수평적인 업체보다는 그래도 직급이라는 것이 존재하고, 클라이언트 갑질이 있고 이러다 보니까 번아웃 되시는 분들이 많아요. 3 4년 차가 되면 이직 하려고 다른 걸 찾다가 그래도 어쨌든 좋아서 발을 들였던 사람이다 보니까 누가 부탁하면 하지 못 하고 그렇게 알음알 음으로 프리랜서 하시는 분이 많은 거 같고요. 이제 저희 지금 모든 PCO가 그러지 않을 텐데, 저희는 나라장터에서 입찰을 통해서 행사를 따거나 아니면 그렇게 매년 진행하는 행사가 있다 보니까 바쁜 시즌 행사 별로 끊어서 줄 수가 있어요. 프리랜서한테, 이건 이 사람만 써서 해도 크게 문제가 없는 거죠. 그러 다 보니까 상시로 인력을 고용하는 것이 아니라 그런 행사가 갑자기 12 월에 몰렸다 하면 지인을 통해서 프리랜서를 구하는 경우가 많고 주변에 이렇게 계시는 분들도 오히려 프리랜서가 몸값이 더 높은 경우도 있거든요. 단기간에 하다 보니까 평소에는 내가 즐길 시간 즐기고 여행도 가고 다른 것도 하다가 행사는 3 개월 내지는 1년 이렇게 해서 다시 조금 쏟아 부었다가 좀 쉬시고 이런 경향이 많이 반복되시는 거 같고. $\langle\mathrm{C}-3\rangle$

프리랜서는 대부분 경력직입니다. 근무 하다가 회사 나가서 그냥 단기 프로젝트로 하시는 분들. $\langle\mathrm{C}-4\rangle$

프리랜서 분들이 자발적인 프리랜서 인 분들도 계시지만 사실은 앞서서 말씀 드린 거처럼 $\mathrm{PCO}$ 에서도 고 정 인력 비용을 상당히 부담스러워하기 때문에 행사 건 별로 이렇게 계약직을 쓰는 경우가 많이 있거든요. 그런 분들은 제 입장에서는 사실은 기간을 어쨌든 끝나는 프로젝트이기 때문에 기간을 정해 놓고 일시적으 로 사용하는 것이 제 입장이지만 그분들은 어떻게 보면 계속 그렇게 계약이 끝나면 다른 행사를 수주한 어떤 기업에 지원하셔야 하는 부분이 있어서...

$\langle\mathrm{C}-2\rangle$ 
여성 종사자가 많다는 PCO 업계 특성 상 경력단절로 인한 프리랜서 전환이 이루어지 는 경우도 빈번한 것으로 나타났다.

좀 가장 안타까운 게 임신을 하거나 자녀가 있을 때는 $\mathrm{PCO}$ 는 안 좋은 직업이다라는 인식을 제 선배들도 많이 가지고 있고, 저 조차도 제가 이걸 육아랑 같이 병행 할 수 있을까 라는 의문을 품고 있는데, 그러면 서 업계에서 물러나셨다가 저희는 아까 말씀 드린 거처럼 프로젝트 단위로 끊어서 업무 하는 것이 가능하 다 보니까 그래서 다시 오셨다가 회사에 소속이 되시거나 그런 식으로 계속 프리로 뛰시는 분들도 계세요. $\langle C-3\rangle$

이 분야는 사실 역량을 갖추기까지 되게 고통의 시간을 겪어야 하는데, 앞서 말씀 드린 거처럼 정말 어떤 어느 정도 (규모의) 행사를 운영 할 수 있는 인력이 그렇게 많지는 않습니다. PCO에 여성분들이 많이 있는 데, 여성분들이 현실적으로 육아나 이렇게 됐을 때 경력단절이 많이 발생 하잖아요. 그랬을 때도 사실 프리 랜서로 활동 하실 수 있는 것이 높은 분야라고 생각을 해요. 어떤 회사에 소속이 되어서 정규적인 급여를 받으면서 진행하시는 경우도 있지만 예를 들어서 우리가 국제회의라고 해서 대규모만 있는 건 아니고 5천 만 원 3천만 원 이런 작은 규모 회의들이 있을 때 그런 부분들은 한 명이 작업 할 수 있는 정말 이렇게 사원급의 임시직 한두 명 있으면 충분히 운용할 수 있는 행사들이 되게 많이 있거든요. 그러다 보니까 프리 랜서로 활동하시는 분들이 상당히 많이 있고. 형태는 개인 사업자 이신 분도 있고 하지만 프리랜서 형태로 딱 정말 일 있을 때만 하시는 분 상당히 많이 있고, 그런 부분들은 사실 얼마든지 자기가 시간을 조율 할 수 있어서 오히려 그런 가능성은 높다고 보고 있습니다.

$\langle C-3\rangle$

프리랜서 활용 유형은 다양하게 나타났다. PCO 업무는 파트별 업무 분장이 용이하여 필요에 따라 프리랜서 활용이 가능하다. 개인 사업자의 지위로 위탁용역 형태로 진행하 는 경우, 회사와 단기 근로계약을 통해 특정 업무에 참여하는 경우 등이 있었다.

형태는 많을 거라고 생각이 되는데요. 몇 가지를 들어 드리면 그런 것들이 있겠죠. 저희가 지난 5 월에 수행했던 포럼 같은 경우에는 국내외 연사만 90 명 정도 되거든요. 그 90 명을 다 내부적으로 관리하고 시간 맞춰 드리고 발표 자료 받고 이런 것들은 너무 어려운 일들이기 때문에 사실 그런 부분 같은 경우에 는 실제로 저희가 같이 일을 하고 있는 프리랜서 물론 그분은 개인 사업자로 등록 하셨지만 그 분에게 위탁을 드리고 그분들이 이제 필요하면 임시직을 한 두 명 뽑아서 그 분이 해외 연사와 컨택하고, 그런 업무들을 저희가 아예 분담해서 그런 이 프로그램이 이렇게 정해져 있으니까 파트를 떼서 프리랜서에게 맡기는 부분이 있고요. 작은 행사 같은 경우에는 이제 아예 그 프리랜서한테 맡기기도 하죠. 저희 회사는 예를 들어서 맡기면서 저희가 현장 지원 인력이라든지 내부의 디자인 요소들 이런 것들을 본사에서 제공을 하면서 전체적으로 클라이언트와 조율하면서 레인지 하는 역할은 프리랜서에 맡기기도 하고요. 그런 맡길 수 있는 범위는 여러 가지가 있다고 보고 있습니다.

$\langle C-2\rangle$ 
프리랜서 분들은 (고용보험 가입) 요청을 하시는 분들이 사실 별로 없습니다. 그분들이 사실 기타 소득을 받길 원하시거나 그렇게 전문적으로 하시는 분들은 사업자등록을 하시는 경우가 많지. 저희가 4대보험 들어 드리기 싫어서가 아니라 그분들이 그렇게 원하시진 않으십니다. 현실적으로. 이건 기업마다 운영하시 는 철학이나 방침이 다르겠지만 사실 4 대보험이라는 것이 저희 입장에서는 보험료를 반반 회사와 개인이 부담을 하지 않습니까? 예를 들어서 10 만원이다 하면 100 만원에 10 만원의 보험료가 나온다면 사용자가 5 만원 부담 하고 근로자가 5 만원 부담 하시는 건데 저희는 105 만원이라고 하면 편한 거거든요. 105 만원 이라고 생각하고 4대보험 하실래요? 라고 똑같이 말씀 드리면, 이분들 입장에서는 95만원 밖에 못 받으시 니까 그냥 기타 소득으로 주세요 하시는 경우가 상당히 많이 있고 본인이 사업자인 경우에 당연히 세금계 산서 처리를 하면 되기 때문에 그럴 필요가 없다 보니까 4대보험에 대한 가입 희망이 프리랜서 분들은 그렇게 많진 않으시죠. 대신에 계약직 분들은 그런 4 대보험 경력 자체가 본인의 커리어가 돼서 이직을 할 때도 그런 거 제출 하셔야 하기 때문에 그런 것들을 희망하시지만 프리랜서는 어느 정도 인지도도 있고 자기가 이걸 할 수 있는 분들이기 때문에 별로 안 원하시는 거 같더라고요. $\langle\mathrm{C}-2\rangle$

개인 사업자가 있으면서 프리랜서로 하시는 분들은 개인 사업자로 계산서 끊어서 하고 있고요. 사업자가 없으신 분은 회사로 계약을 해서 단기 프로젝트로 계약해서 진행을 합니다. 실제로.

$\langle\mathrm{C}-4\rangle$

\section{2) PCO 사각지대_단기 근로자}

$\mathrm{PCO}$ 업계 특성상 소수의 정규직으로 운영하는 것이 일반적이며, 프로젝트 단위로 필 요인력을 단기 계약직으로 활용하는 것으로 나타났다.

저희가 행사를 하나 운영하는 데 있어서 사실 PCO라는 업무는 오거나이저 역할이 많거든요. 초기 프로그 램으로 하면 프로듀서의 역할이 많다고 생각합니다. 어떤 작품을 하나 만들기 위해서 기획자가 있을 것이 고 사실 거기에 뭐 시스템 팀도 들어가야 할 거고 요즘에 당연히 어떤 컨퍼런스를 진행하게 되면 웹사이트 도 만들어야 할 거고, 이런 여러 투어도 붙여야 할 거고 여러 가지가 있으니까 그런 것들을 저희가 다 할 수는 없고, 그런 것들이 다 협력 팀들 외주로 진행을 하거든요. 한정된 예산에 주최자가 원하시는 어떤 목적을 달성하기 위해서 그러면 어떤 여행사를 붙여야 하고 호텔은 어떤 호텔을 가야 하며 어떤 식사를 해야 하고 이런 것들을 기획해서 어우러지게 만드는 것이 $\mathrm{PCO}$ 의 역할이라고 할 수 있기 때문에 $\mathrm{PCO}$ 의 상용 근로자의 수가 많을 필요는 없습니다. $\mathrm{PCO}$ 가 그렇다 보니까 인원이 많진 않은 편이고요. 그러다 보니까 어떤 행사를 했을 때 참가자 관리다. 참가자가 1000 명이면 그 1000 명한테 오는 메일과 전화를 다 받아야 할 거잖아요. 물론 전화 하시는 분이 몇 \% 된다. 100 명의 전화를 받아야 하고 이런 부분에 있어서 어떤 프로젝트가 진행되는 과정 과정에서 필요한 인력들은 계약직 형태로 많이 채용하게 되죠. 물 론 그렇게 채용된 계약직 중에 일을 잘하는 친구는 정규직으로 전환되는 경우도 있고요. 크게 어떤 기본적 으로 이 행사를 기획하고 제안하고 클라이언트가 운영하고 이런 어떤 정규적인 일을 하시는 분들이 있을 거고, 행사 운영 과정에 따라서 추가적인 계약직들 상당히 많이 필요하고 현장에는 상당히 많은 인력이 필요한데, 대체로 PCO 인력이라기 보다는 협력 업체 현장 운영 같은 경우도 인력 전문 운영 업체들한테 많이 외주를 주거나 아르바이트 생을 뽑아서 운영하기 때문에 그런 현장 인력은 대체로 외주 또는 임시 인력이라고 보면 될 거 같습니다.

$\langle\mathrm{C}-2\rangle$ 
현장 인력, 진행요원은 외주 인력전문 운영업체를 통해 수급하거나, 일용직으로 직접 공고 후 채용하여 진행한다.

두 가지가 있어요. 행사 인력만 전문으로 하는 인력대행사가 있어요. 여기는 내레이터 모델, 레이싱 모델 이런 모델들 있죠. 의전 도우미, 행사 전문요원들, 일반 아르바이트 경호인력 이렇게 해서 섭외를 해주는 인력 대행사가 있어요. 이 사람들은 머리 수 $+1 ~ 2$ 만원 붙이거든요. 그렇게 해서 오는데, 사실 그렇게 하면 불특정 다수가 오는 경우가 많아서 저희는 좀 많이 하고 있는 부분들이 대학교 사회체육과 학생들을 공략을 합니다. (중략) 큰 데들은 그렇게 해서 일일이 관리하기 힘드니까 인력대행사 통해서 일괄 받기도 하고 있습니다.

$\langle\mathrm{C}-1\rangle$

진행요원은 일용직으로 해서 저희가 0000나 MICE 관련된 사이트에 공고를 올리고 거기서 학생들이 지원 을 하고 학교에 있는 취업 사이트에 올리고 지원을 해서 들어오게 진행하고 있습니다.

$\langle\mathrm{C}-4\rangle$

거의 진행요원들처럼 그냥 이제 건 바이 건으로 그냥 행사 일정 시간, 혹시나 한 달 이상이 된다면 월급 수준으로 협의를 해서 진행하기도 하고요. 그 대신 계약이 되어 있는 상태는 아니기 때문에 무조건 그분이 랑 한다는 건 아니고 사전에 연락을 통해서 일정 조율이 가능하면 하는 식으로 진행하고. $\langle C-3\rangle$

인턴제를 도입, 적용하기 때문에 시작하는 급여가 낮다는 점도 언급되었다. 일용직, 단기 근무 근로자의 경우 많은 업체에서 4대 보험을 적용하지 않는 것으로 나타났다.

계약직이라는 미명 하에 2 3개월씩 보통은 저희 업계가 비수기 성수기가 있다 보니까 계속 인력을 꾸준히 데리고 가는 것이 아니라 계약직으로 급할 때 써보고 괜찮으면 인턴을 해보고, 다시 사원을 시킨다든가 하다 보니까 시작하는 급여가 낮은 경우도 왕왕 있고요.

$\langle\mathrm{C}-3\rangle$

요즘에는 하루 이틀 아르바이트 해도 근로 계약이나 보험을 들으라고 권유를 많이 하는 거 같아요. 그런데 그렇게까지는 솔직히 안 하고 있는 거 같고요. 보통 한 달 이상 저희도 같이 일을 하는 친구들은 당연히 근로계약서도 작성 하고 4대 보험도 당연히 다 지급을 하는데, 하루 이틀 아르바이트 하는 학생들은 사실 은 그렇게까지는 저희도 안 하고 있고, 아마 많은 업체에서 그렇게까지 하고 있지 않는 거 같습니다. 아마 도 세법 상에서도 아마 일 얼마 이상은 원천징수를 안 해도 되는 부분이 있어서 그 기준을 넘지 않는 범위 에서는 4 대보험을 가입하고 있지 않습니다.

$\langle C-2\rangle$

저희가 사실 그분들을 따로 고용보험을 들어드리지 않는데, 이것도 몇 개월 이상 된다면 들어 드릴 수 있지만 제가 같이 하셨던 분들은 따로 고용보험을 들어 드리지 않았고요. 그래도 신고는 하잖아요. 일용직 할 때 그런 정도의 세금만 하는 걸로 알고 있어요.

$\langle\mathrm{C}-3\rangle$ 
제가 볼 때는 본업이 있으시면서 이걸 뛰어 준다기 보다는 이런 업무들만 많이 하셨던 분들인데, 저희가 심지어 그런 분들 중에 한 두 분한테는 그냥 저희랑 같이 일하자 라고 오퍼를 한 적 있었는데, 그냥 회사에 소속이 되는 상황이 싢고, 그냥 이제 하게 되면 페이퍼 워크도 해야 하고 전화라든가 되게 많았는데, 본인 은 해봤더니 오히려 현장에서 일하는 건 재미있고 즐겁지만, 뭔가 소속이 돼서 꾸준히 출근을 하고 이런 것들이 힘들어서 이걸 택한다 하시는 분들이 있으시더라고요. 그래서 소속되는 걸 자체를 거부하시는 분도 계셨어요.

$\langle\mathrm{C}-3\rangle$

정규로 계약해서 고정 하는 인원이 있고요. 그 다음에 큰 프로젝트 할 때는 프리랜서를 계약해서 단기계약 직으로 하는 친구가 있고요. 행사 기간만 지원하는 어떤 일시적인 고용 형태, 진행요원은 행사 기간만 하지 만 행사 기간 전에 며칠 전에 2주 정도만 근무하는 일시 계약직 인원이 있고, 인턴들 고정 인턴들 2 3개월 6 개월까지 하는 인턴이 있고, 인턴이라는 과정을 겪게 되면 프로젝트 계약직으로 할 수 있는 권한을 부여 를 해서 프로젝트랑 인턴이 다른 건 분과 배정을 해서 진행을 합니다. 그래서 분과 배정을 진행하는 인원 이 있고. 취업을 하기 위해서는 업계가 뭐 홈페이지나 이런 잡코리아에 공지하는 공채 스타일이 있고요. 저희는 공채는 일절 안 하고 있고요. 진행요원이나 친구를 통해서 알게 된 인턴을 제시해주거나 아니면 학교 교수님들 통해서 좀 더 검증 받은 인원을 인턴으로 먼저 근무를 시켜 보고 인턴을 했을 때 저희가 맞는 인원만 프로젝트 계약직으로 변환을 시키고 실제 업무를 주고 잘 했을 때는 고정 사원으로 진행하는 방향으로 저희가 실제 운영하고 있습니다. 다른 회사는 아마 고정 공채를 많이 올려서 실시간 올려서 뽑는 거 같아요. 그리고 통역 하시는 분들은 이제 협력사 파트인데요. 동시통역사 분들은 동시통역 하는 00 대라 든지 아태통번역 기관들이 있습니다. 그쪽에서 섭외를 해주면 저희가 그분들 고용하게 되고, 그분들은 아 예 정해져 있는 시간 6 시간 기준 90 만원 2인1조 정해져 있고요. 기자재 업체는 기자재 견적 받아서 거기 다 테크니션이라는 항목이 있습니다. 그분들 비용을 처리해드리고, $\langle\mathrm{C}-4\rangle$

실행할 때는 어느 정도 인원이 담당자가 붙어줘야 하거든요. 여러 가지 일을 하면서 놓치는 게 많이 생기 기 때문에 그게 단기적인 일이라면 단기적으로 사람을 쓰게 되는 경우도 있고, 특히 행사를 진행 할 때 현장에 대한 인력이나 이런 부분은 특히나 아르바이트를 쓰게 되죠. (중략) 우리가 일용직 썼던 인원은 날 수로 계산하잖아요. 1일씩으로 계산해서 보니까 250명 되더라고요. 일용직은 그렇게 하루를 계산 해서 하루를 1 일로 쳐서 인원으로 계산하니까 250 명 정도 되고, 연간 근무 인력은 1년 평균해서 8 명이 되고 8명은 정규직이긴 한데... $\langle\mathrm{C}-1\rangle$

진행요원이 고용보험을 $100 \%$ 하는지 안 하는 진 모르겠어요. 진행요원들이 예전에는 고용보험을 가입을 안 했기 때문에 끝나고 현금지급을 했기 때문에 그런 부분들이 개선이 됐고요. 통역사 분들은 당연히 통역 업체를 통해서 해서 고용보험이 어떻게 되어 있는지 모르겠지만 그거까지는 모르겠어요. 기자재 업체 분들 은 회사에 소속되어 있어서 고용 보험은 다 되어 있고요. 뭐 공연팀들 이럴 때는 다 회사랑 저희가 계약을 하기 때문에. 벤더들에 대한 고용보험까지는 저희가 모르겠어요.

$\langle\mathrm{C}-4\rangle$ 


\section{라. 향후 전망}

앞으로 $\mathrm{PCO}$ 업계 발전을 위해서는 디지털 인력에 대한 지원 사업 등 앞으로의 산업 환경 변화에 대응하기 위한 지원을 강화할 필요가 있으며, 산업적으로 전문 인력에 대한 지원과 보호 체계를 갖출 필요가 있다는 의견이다.

전문 인력에 대한 지원과 보호 같은 부분일 거 같아요. 예를 들어서 지금 디지털 인력에 대한 지원 사업 같은 경우 많이 하고 있잖아요. 저희도 중소기업들도 다 $\mathrm{PCO}$ 들도 직원들 뽑을 때 디지털 인력이라고 써내 면 지원해주고 이러고 있거든요. 어쨌든 그런 부분들이 되게 잘 되어 있고 소프트웨어 산업 같은 경우에는 물론 그 분야에도 게임 회사 개발자들 착취하고 이런 문제들 되게 많이 있지만 산업적으로 소프트웨어 인력을 보호하기 위한 장치들은 많이 하고 있다고 저는 생각하거든요. 그런 인건비 부분이라든지, 이런 앞서 말씀 드린 디지털 인력지원 사업이라든지, 그런 부분들이 상당히 많이 있는데, 우리 업계는 그런 부분 은 좀 약하지 않나 생각을 많이 하고 있고.

$\langle\mathrm{C}-2\rangle$

\section{5. 분석결과 종합}

이 절은 관광산업 고용안전망 실태 파악과 사각지대 규명에 초점을 두고 심층인터뷰 조사 결과를 분석하였다. 관광산업에 종사하고 있으나 고용보험 등 안전망에 포함되지 않은 대상이 누구인지, 코로나19 관련하여 고용보험 등 정부의 지원사업을 적용받지 못 한 대상과 이유는 무엇인지 등 사각지대의 현황과 발생 원인을 살펴보았다.

심층인터뷰 조사를 통해 도출한 관광산업 고용안전망 사각지대의 현황과 특성은 다음 과 같다.

첫째, 관광산업(여행업, 숙박업, 국제회의기획업 등)은 입직이 쉽고, 이직도 쉬운 노동 시장의 유연성이 큰 산업으로 인식하였다. 여행업, 관광숙박업 등 종사자의 고용 불안정 이 큰 산업으로 인식되었다. 낮은 보수(대기업 계열 안에서도 관광업계는 낮은 처우)와 열악한 근무 여건 등은 이직이 빈번한 사유로 작용한다. 관광업계의 영세성과 저수익 구조는 저임금 노동시장을 형성하게 되는 구조적 문제를 안고 있는 것으로 나타났다.

둘째, 수요의 불규칙성, 성비수기와 계절성 등으로 고용형태가 다양하게 나타났다. 호 텔, 리조트 등 숙박업은 주말, 주중의 차이, 성비수기의 계절성으로 인한 아르바이트 등 임시일용직 고용형태가 일반적이며, 직접고용을 줄이고, 외주화 영역을 확대하는 추세이 다. 관광가이드 역시 여행사에서 정규직 근로자로 고용하기 어려운 이유 중 하나는 수요 
가 불규칙하기 때문으로, 영세한 여행업에서 가이드를 대상으로 고정 급여를 지급한다는 것이 부담으로 작용하였다.

셋째, 관광산업 종사자들이 우려하는 지점은 전문성의 약화였다. 관광가이드는 과거 민간외교관으로 나름의 전문성을 인정받았으나 현재는 그 위상이 약화되었으며, 호텔에 서의 기업의 서비스 표준화 시도는 종사자의 경력과 무관하게 어떤 사람이 와도 업무를 대체할 수 있도록 표준모델을 구축하여 결국 종사자의 경력 개발을 무의미하게 만들 우 려가 있음을 지적하였다. 관광산업은 인적 서비스 기반, 종사자의 전문 역량 강화는 중 요한 과제로 나타났다.

넷째, 코로나19 이후, 휴업, 휴직 등 고용 위기 상황은 여행업과 관광숙박업 현장에서 심화될 것으로 판단된다. 2020년은 경영 위기에 처한 업계가 고용유지지원금, 고용안정 협약지원금 등을 통해 고용을 유지하는 것으로 나타났다. 관광산업 종사자를 대상으로 진행한 심층인터뷰 조사 결과에서는 고용보험의 가입 대상이 아닌 프리랜서, 초단시간 근무자, 영세자영업자 등 고용안전망의 사각지대에서 코로나 19 가 고용안전망의 필요성 을 인식하는 계기가 되었음이 확인되었다.

마지막으로, 관광산업의 디지털 전환으로 인한 직무 환경 변화의 필요성에 대한 인식 이다. 여행업은 기업 환경 변화로 종사자의 직무 역량 변화가 요구되며, 이로 인한 기존 종사자들의 고용불안정성이 심화되는 것으로 나타났고, 교육을 통한 전환과 재배치 및 새로운 직무 역량의 필요성에 대한 인식이 높게 나타났다.

〈표 4-29〉 심층인터뷰 조사 결과

\begin{tabular}{|c|c|}
\hline 범주 & 주제 \\
\hline \multirow{3}{*}{$\begin{array}{c}\text { 노동집약적 특성이 우세한 관광산업 } \\
\text { 고용 현실 }\end{array}$} & 진입장벽이 낮음 \\
\hline & 전공역량 및 스펙 보다 태도 중시 \\
\hline & 인력 중심의 서비스 제공 구조 \\
\hline \multirow{4}{*}{ 업의 전문성, 자부심 결여 } & 높은 이직률, 잦은 이직 고민 \\
\hline & 외부 시각과 현실과의 높은 괴리감 \\
\hline & 정규직보다 높아지는 비정규직화 추세 \\
\hline & 낮은 보수체계와 처우로 인한 회의감 \\
\hline 낮은 고용 안정성 & 외부 환경변화에 민감 \\
\hline \multirow{3}{*}{$\begin{array}{c}\text { 관광분야 고용 불안정성과 } \\
\text { 사각지대 발생 }\end{array}$} & 산업구조의 영세성과 정부지원 사각지대 \\
\hline & 고용 환경의 열악함 인식 \\
\hline & 고용보험 제도화의 제약 요인 \\
\hline
\end{tabular}




\begin{tabular}{c|l}
\hline 범주 & \multicolumn{1}{c}{ 주제 } \\
\hline \multirow{2}{*}{$\begin{array}{c}\text { 코로나19 이후 심화된 } \\
\text { 고용 및 일자리 위기 }\end{array}$} & 코로나19로 휴직, 희망퇴직, 정리해고, 폐업 등 고용/일자리 감소 \\
\cline { 2 - 2 } & 코로나19로 심화된 관광분야 고용의 질 저하 \\
\cline { 2 - 2 } & 정부의 고용유지지원 수혜 인식과 한계 발생 \\
\hline \multirow{2}{*}{$\begin{array}{c}\text { 정규직 이외의 다양하고 불안정한 } \\
\text { 고용 형태 }\end{array}$} & 계절성, 성/비수기 발생 요인 \\
\cline { 2 - 2 } & 경영 이익을 위한 값싼 노동력 대체 현상 \\
\cline { 2 - 2 } & 다양한 고용 형태 속 갈등 심화 \\
\hline
\end{tabular}




\section{제4절 종합분석 및 시사점}

\section{1. 관광산업 고용안전망 실태분석 결과}

4장은 관광산업 주요 업종별 고용형태 등 노동시장 특성을 파악하고 고용안전망 사각 지대의 실태를 파악하는데 주안점을 두었다. 특히, 고용안전망 사각지대 실태 규명을 위 하여 고용유지지원금 수급 현황, 긴급고용안정지원금 수급자 통계 등을 분석하였다.

첫째, 고용유지지원금을 받고 있는 사업체와 종사자는 관광사업체조사에서 파악된 전 체 업종 규모의 약 10 20\% 수준인 것으로 나타났다.

둘째, 고용보험에 가입하지 못한 사람들을 대상으로 한 긴급고용안정지원금 수혜 현 황 조사를 통해 관광산업에서 고용안전망의 사각지대에 놓여있는 일하는 사람들의 현황 을 살펴보았다. 1 차 긴급고용안정지원금 수급자 중 여가관광종사자는 약 7 천명으로, 전 체 관광산업 종사자 규모에 비하면 약 $2.5 \%$ 수준이다. 수혜자 그룹의 기초 현황 자료는 관광산업 고용안전망 사각지대를 파악하기 위한 단서가 될 수 있다.

긴급고용안정지원금 수급자 현황에서 나타난 시각지대 현황을 살펴보면, 소득감소율 에서 여가관광종사자가 평균 $85.1 \%$ 로 타 직종의 프리랜서, 특수고용직에 비하여 월등히 높게 나타났다. 소득구간 분포에서도 1 2분위 구간이 약 $60 \%$ 수준으로 높았고, 연평균 소득은 약 3,300만원으로 분석되었다. 또한 연령대는 20 40대가 58.3\%로 높고, 근무 기간도 2년 미만이 절반 이상을 차지하는 것으로 나타났다.

관광산업은 일용근로자, 자영업자, 프리랜서 등 고용형태가 다양하고, 소득 파악이 어 려운 부분에 취업한 근로자는 상용근로자 중심으로 설계된 현재의 고용보험에는 여전히 가입하기 어려운 상황이다. 전국민 고용보험이 단계적으로 추진되고 있기 때문에 향후 다양한 행정 $\mathrm{DB}$ 를 이용하여 고용안전망 사각지대 발굴과 현황파악이 요구된다. 


\section{2. 관광산업 고용안전망 사각지대 진단}

앞서 도출한 고용안전망의 사각지대에 대한 업종별 심층인터뷰 분석결과와 그동안 연 구된 내용을 토대로 고용안전망 사각지대가 어느 영역에 속하는지를 규명하였다. 정흥준 (2020)은 고용안전망 사각지대를 크게 직접고용과 간접고용의 형태에 따라, 그리고 고 용보험 적용과 법적 사각지대인 고용보험 적용 제외자로 분류하여 매트릭스로 제시한 바 있다(그림 2-2 참조). 이에 따르면 고용보험이 적용되면서 직접고용이 이루어지는 직 군은 고용유지지원금 및 실업급여가 보장되어 비교적 고용안전망이 형성되어 있다고 볼 수 있으나, 초단시간 노동자, 1 4인 영세 사업체 노동자 등 직접고용이 이루어지지만 고용보험 적용이 제외되거나, 파견노동자나 사내하청 노동자와 같이 고용보험은 적용되 나, 간접고용이 이루어지는 경우, 그리고 특수고용노동자, 플랫폼노동자이거나 일일노동 자와 같이 간접고용이면서 고용보험도 제외되는 경우까지 그 형태가 다양하다고 제시하 고 있다. 이를 토대로 심층인터뷰와 선행 자료 분석 결과에서 도출된 관광산업의 고용안 전망 사각지대를 다음과 같이 제시하고자 한다.

\section{가. 프리랜서/기타 특고 노동자}

우선, 가장 핵심인 고용안전망 사각지대로서 고용보험 적용이 제외되면서 간접고용 위치에 놓인 근무자들은 여행업에서는 국외여행인솔자(TC)와 관광통역안내사가 대표적 이다. 프리랜서 형태로 근무하는 성격이 강하여 고용보험 적용에 제외가 되는 경우가 많다. 일부 관광통역안내사의 경우 고용보험에 적용되기도 하지만 최근에는 이 또한 감 소하는 추세를 보인다. 국제회의기획업은 경력직 프리랜서 전환이 활발한 것으로 나타났 고, 특히, 여성의 결혼, 출산, 육아 등의 상황에 따라 경력단절에 따른 프리랜서 전환의 경우도 적지 않은 것으로 파악된다. 국제회의를 기획하거나 개최하는데 있어서는 일일 근무자 형태도 적지 않은데 이 경우에도 사업체 규모나 수준에 따라서 고용보험 적용을 제외하기도 하는 것으로 파악되었다. 숙박업의 경우에는 원래 숙박업체 근무자가 퇴직한 후 다시 재고용이 되는 실버인력의 경우 고용보험 적용에서 제외되는 경우가 존재한다. 이외 인터뷰에서는 파악되지 않았으나 최근 여행 OTA 등 플랫폼이 늘어나면서 플랫폼 내 프리랜서 가이드가 상품을 판매하는 경우 고용보험에 적용되지 않는 경우가 많은 것 
으로 추정된다. 이들 모두는 가장 대표적인 사각지대에 놓인 종사자이다.

\section{나. 영세사업체 노동자}

둘째, 직접고용 형태를 띠고 있으나 고용보험 적용에서 제외되는 경우가 존재한다. 여 행업의 경우 랜드사 및 소규모 여행사 등의 근무자나 자영업자, 그리고 무급가족종사자 등 1 4인 영세 사업체 노동자가 여기에 해당하는 것으로 나타났다. 숙박업의 경우 직접 고용 형태를 띠기는 하지만 하우스키핑 등 단순노무직종으로 분류되는 경우 일일 노동 자 형태로 근무하기도 한다. 이외 초단시간 근무자도 존재하는데 국제회의 개최 시 필요 인력이나 숙박시설의 경우 소규모 시설은 초단시간 근무자가 존재한다. 최근 여행 OTA 플랫폼에는 체험 프로그램 등을 직접 등재하고 운영하는 경우도 있는데, 이 경우 1 4인 영세 사업체가 존재하며 고용보험 적용에서 제외되는 경우가 발생하는 것으로 추정된다.

\section{다. 관광 관련 산업 종사자}

셋째, 고용보험이 적용되기는 하지만 관광업종으로 인정되기 어려운 이른바 파견노동 자나 사내하청 노동자들이다. 이 경우 관광 위기 상황에서 각종 관광진흥법상 지원 정책 신청 및 수혜시 사각지대에 놓이거나, 특히 필요 시 정리해고나 파견 외주협력업체 또는 자회사를 폐업하는 등 표면적인 경우 고용안정화가 이루어져 있지만 실질적으로는 고용 이 불안한 근무자들로 볼 수 있다. 숙박업이 최근 대표적으로 외주협력업체를 통해 근무 형태를 높이는 것을 볼 수 있으며, 이외에도 숙박시설의 초단시간 근무자의 경우 외주협 력업체에서 일부는 고용을 취하는 것으로 나타났다. 흔히 OTA의 활성화는 많은 부분 숙박 OTA 플랫폼이 주도하는 것을 볼 수 있는데 숙박 OTA 플랫폼 내 종사자들 역시 직접적인 관광업종 종사자로 볼 수 없는 한계가 있다.

\section{라. 잠재적 사각지대}

마지막으로, 직접고용이 이루어지면서 고용보험이 적용되는 고용안전망이 형성되어 있는 군집으로 고용유지지원금 및 실업급여 보장 범위 내 속한 근무자가 존재한다. 이 경우 당장의 고용은 유지가 되며, 특히 앞으로의 실업 상황에서의 대안이 존재하기는 하지만, 향후 직종 자체가 감소하면서 창업, 창직 등의 필요성이 존재하는 경우를 의미 
한다. 이들은 광범위한 수준의 고용안전망 제도 내에서 대책이 필요한 군집으로 볼 수 있다.

이러한 특성들을 종합적으로 고려하여 [그림 4-16]과 같이 관광산업의 고용안전망 사 각지대를 제시할 수 있다. 다만, 제시된 고용안전망 사각지대는 기준 시기와 특성에 따 라서 변화될 수 있기 때문에 지속적인 모니터링을 통해 검토가 필요하다. 또한 이 연구 에서는 관광산업 중 여행업, 관광숙박업, 국제회의기획업을 중심으로 분석 결과를 제시 하였다. 따라서 전체 사업자 및 종사자 실태조사를 토대로 관광 분야 전반의 사각지대 파악으로 확대할 필요가 있다.

[그림 4-16] 관광산업 고용안전망 사각지대 결과

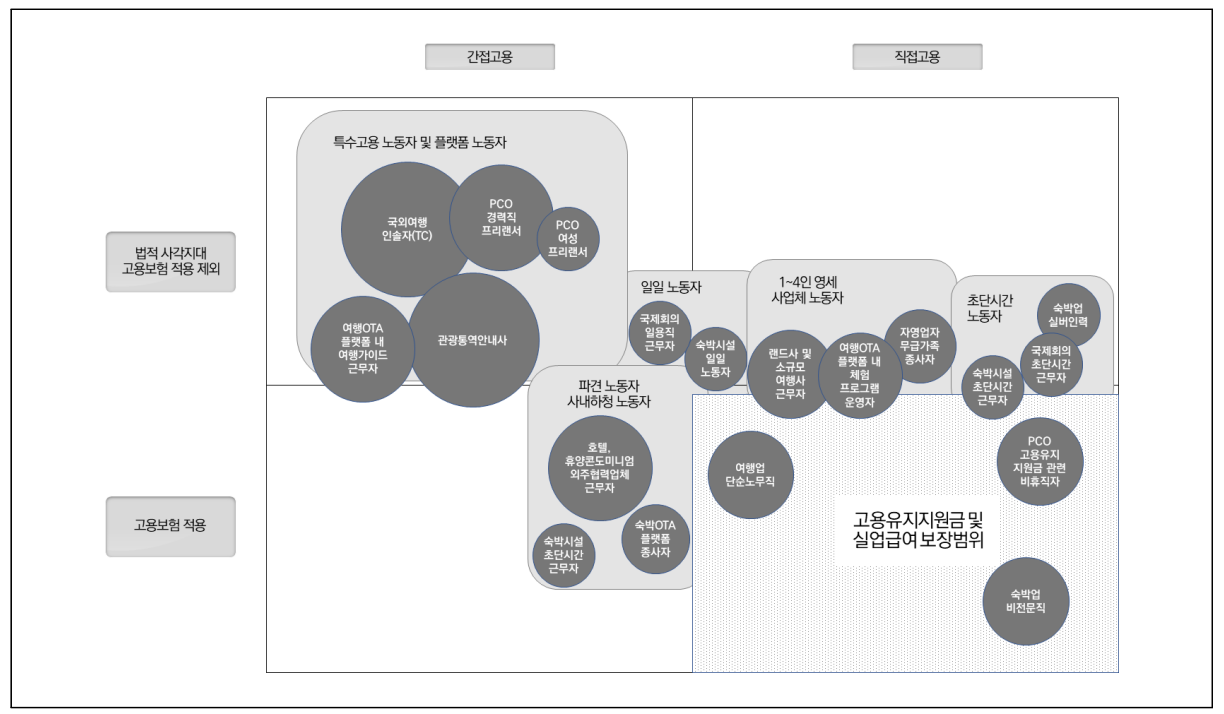



관광산업 고용안전망 구축방안

제5장

관광산업 고용안전망 강화를 위한 과제 



\section{제1절 관광산업 고용안전망의 필요성}

포스트 코로나 대비하여 급속히 변화하는 고용-노동 환경에 대응하기 위해 탄탄한 고 용안전망을 구축하고, 관광산업에서 사람에 대한 투자를 강화하는 정책 방향 설정이 필 요하다. 고용과 일자리는 관광산업 정책에서 무엇보다 중요한 과제이다. 종사자의 고용 안정을 도모하면서 관광기업의 지속가능성을 강화하는 균형적 접근이 필요하다. 이러한 배경에서 본 연구는 관광산업 고용안전망 강화를 위한 정책 방향을 제시하였다.

\section{가. 관광산업은 고용유연성이 큰 산업 $\rightarrow$ 고용불안정성 심화}

관광산업 경쟁력 강화와 지속가능한 발전을 위해서는 관광산업의 고용안전망을 강화 할 필요가 있다. 코로나19로 촉발된 고용위기로 고용안전망 강화는 중요한 화두이다. 2020년 12월부터 문화예술인의 경우 고용보험이 시행된 부분이나, 2021년 특수고용직 고용보험 시행에 차질이 없도록 적용직종 선정 등 하위법령 개정을 추진하여 산재보험 이 적용되는 보험설계사와, 학습지교사 등 12 개 직종에 고용보험을 우선 적용하는 등 고용안전망 강화 정책이 실질적으로 수립된 것도 이와 같은 맥락이라 볼 수 있다.

관광산업 역시 고용안전망 강화와 사각지대 해소가 시급하다. 관광산업은 상대적으로 산업에서의 노동 비중이 큰 산업이면서 동시에 노동유연성이 큰 산업이다. 특히, 전통적 으로 성수기와 비수기가 존재하는 계절성의 변동이 큰 특성 때문에 고용유연성이 심하 게 나타나고 종사자의 고용 불안이 높은 편이다. 그럼에도 노동 비중이 높다는 점은 노 동 전문성이 곧 산업의 경쟁력에서 중요한 요인임을 시사한다. 
[그림 5-1] 2019년 기준 업종별 입직률 및 이직률

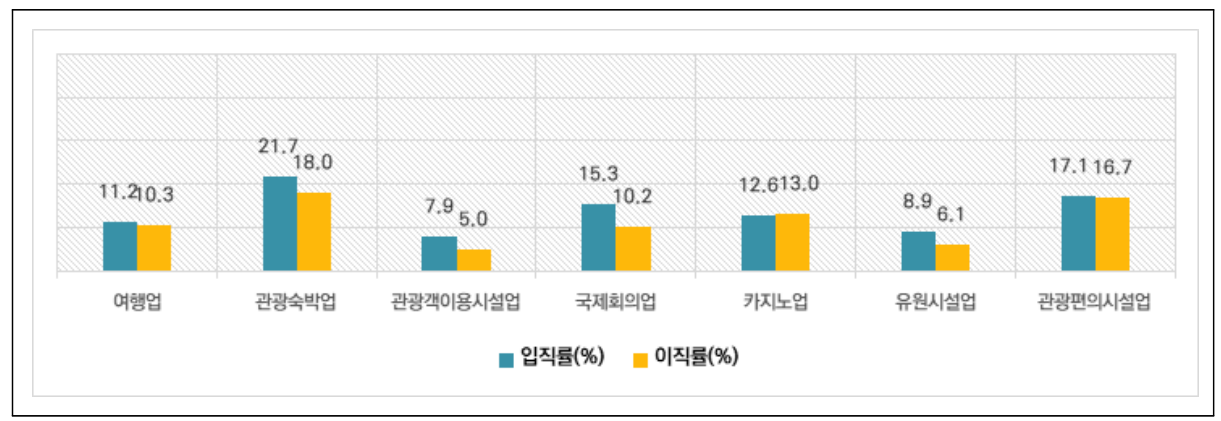

자료: 문화체육관광부·한국문화관광연구원(각 년도). 관광사업체조사

2019년 기준 업종별 입직률과 이직률을 살펴보면 여행업, 관광숙박업, 국제회의업 등 에서 변동성이 높게 나타난다. 고용안전망 확충은 관광산업에 종사하는 근로자의 고용안 정과 근로조건 향상을 통해 관광분야 양질의 일자리 창출에 기여 할 수 있을 것이다.

\section{나. 위기에 취약한 산업 $\rightarrow$ 코로나19 등 관광산업 고용 위기 대응}

관광산업은 외부 요인의 영향을 많이 받는 산업이다. 외부 요인에 취약하다는 것 또한 종사자의 고용 불안을 야기한다. 코로나 19 로 인한 관광산업의 고용 위기는 종사자 보호 와 고용정책의 중요성을 환기하는 전환점이 되었다. 코로나 19 의 종식과 회복시점이 불 투명한 상황에서 고용 위기감은 더욱 커지고 있다. 그러나 관광산업은 단지 코로나19만 이 아니라, 심층인터뷰 과정에서 나타난 것처럼 일본수출규제, 중국 사드 등 외부 환경 요소에 따라 갑자기 일자리가 사라질 수도 있는 시장이다. 이러한 위기 상황에서 종사자 에 대한 사회적 보호 체계를 갖추는 것은 관광산업 위기 관리 차원에서 중요한 부분이다.

[그림 5-2] 주요 특별고용지원업종 생산지수 및 피보험자수 감소 현황

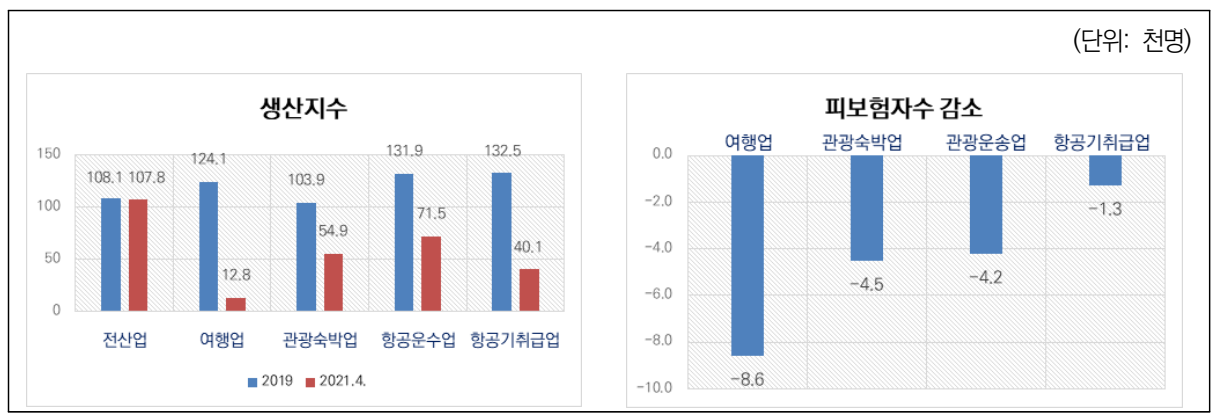

자료: 고용노동부(2021) 
코로나19 이후 노동시장은 고용안전망의 사각지대에 내몰린 근로여건으로 인해 관광 업계의 저임금 구조, 고용 불안정성이 커질 수밖에 없는 실정이다. 코로나19 상황에서 관광산업의 약한 고용관계인 프리랜서나 위탁협력업체 등의 관계가 표면화되었고, 관광 위기 상황이 지속되면서 정부의 한시적이고 특수한 지원책이 수립되어 고용안전망 관련 정책과 지원이 추진되고 있다. 향후 일시적 상황이 아닌 상시적이고, 장기적인 고용안전 망 관련 정책 수립을 통해 보다 안정적인 관광산업의 고용 유지와 전문성 있는 관광 종 사자들의 근무가 가능할 것이다.

\section{다. 취약한 노동시장 $\rightarrow$ 취약계층 노동자가 집중된 일자리}

관광산업 종사자는 30대 미만의 청년 노동시장의 비중이 높은 편이며, 초기 노동시장 진입장벽이 낮은 특성을 지닌다. 2019년 기준 관광사업체 종사자의 연령별 분포를 살펴 보면, 30세 미만 40세의 비중이 전체 종사자의 $54.8 \%$ 로 높게 나타났다. 노동시장을 구 성하는 연령대의 특징과 변화도 고려할 필요가 있다. 예컨대, 관광숙박업은 최근 65세 이상의 실버 인력 활용에 대한 노동시장의 수요가 늘고 있는 것으로 나타났다.

관광산업 종사자는 청년과 여성의 비중이 상대적으로 높고, 경력단절여성, 실버인력 등 재취업이 증가하는 추세로 노동 취약계층에서 일자리가 늘고 있다는 점도 고려할 필 요가 있다. 고용안전망 사각지대 보완이 취약계층 일자리에 갖는 의미가 크기 때문에 사각지대 해소를 위해 관광산업 고용안전망 구축 과정에서 이들에 대한 충분한 고려가 요구된다.

[그림 5-3] 연령별 종사자 분포

(단위: \%)

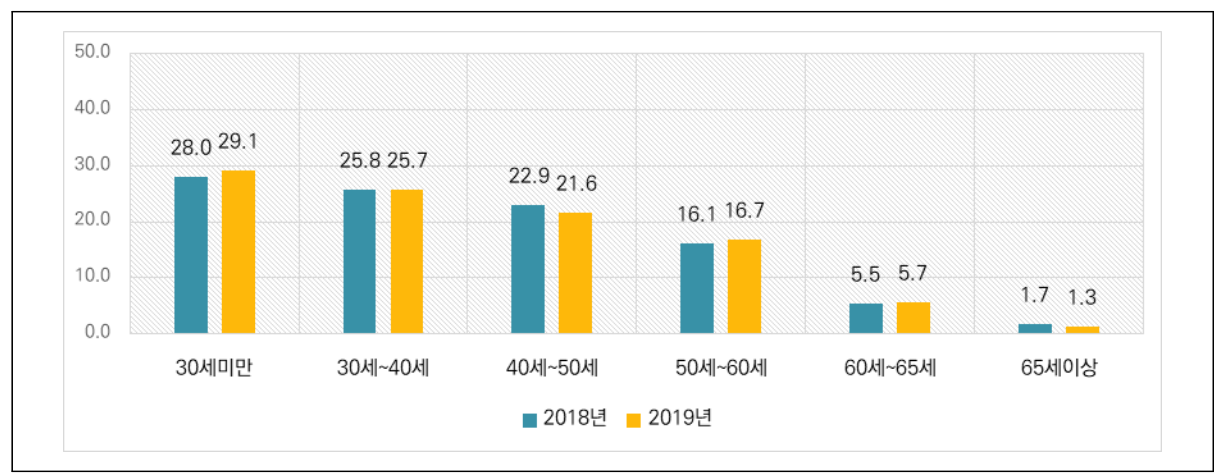

자료: 문화체육관광부·한국문화관광연구원(각 년도). 관광사업체조사 


\section{라. 고용형태의 다양화와 인력의 탄력적 활용}

고용형태는 비정규직과 외주화가 지속적으로 늘어나고 있다. 관광산업 노동시장에서 위탁용역 등 인력의 탄력적 활용이 증가하는 추세이다. 직접고용보다는 외주용역, 협력 사 및 위탁업체 전환이 확대되고 있다. 중소규모 호텔의 경우, 노무 관리의 어려움을 이 유로 하우스키핑, 미화, 시설 관리 등을 위탁 용역 방식으로 전환하는 시례가 늘고 있는 현실이다. 프론트, 조리사, 경영지원팀 등 전문성이 요구되거나 경영 핵심 부서를 제외 하고는 대부분 외주화되고 있다.

고용형태에서는 임시 일용직의 비중도 높게 나타났는데, 유원시설업이나 관광숙박업 등과 같은 일정 규모 이상의 시설 운영을 기반으로 하는 업종에서 더 높게 나타났다. 이는 성수기와 비수기, 주말과 주중 영업의 변동성으로 인하여 비정규직 근로자의 수요 가 상대적으로 큰 특성이 반영된 것으로 볼 수 있다. 저숙련 근로자로 영업하는 구조에 서는 임금체계의 변화가 느리게 나타난다. 고용의 안정성 확보로, 산업 생태계 안에서 종사자가 경력 관리를 이어갈 수 있도록 만드는 것이 필요한 이유이다. 


\section{제2절 관광산업 고용안전망 구축 방향과 과제}

\section{1. 관광산업 고용안전망 사각지대 해소}

고용안전망 강화는 정책 수혜 대상의 확대를 통하여 고용안전망의 사각지대에서 일하 는 사람들이 정부의 정책적 지원과 혜택을 적용받을 수 있는 구조를 만드는 것이다. 이 러한 배경에서 정부는 전국민 고용보험 가입을 위한 정책을 지속 추진하고 있다. 전국민 고용보험 로드맵 구상에 부합하여 관광 및 관련 업종 역시 고용안전망 사각지대 해소를 위한 노력을 강화할 필요가 있다.

전국민 고용보험 가입의 단계적 도입을 위해서는 우선적으로 관광산업이 고용보험 가 입의 필요성을 업계와 근로자 모두가 함께 인식하고 고용보험 가입을 위한 노력을 기울 여야 한다. 궁극적으로 전국민 고용보험 가입 대상에 관광 관련 종사자가 포괄적으로 포함이 되어야 할 것이나, 정부가 발표한 로드맵 상 우선적인 검토가 필요한 대상은 관 광통역안내사 및 국외여행인솔자 등 관광가이드이다. 특히 프리랜서 형태로 활동하는 관 광가이드를 중심으로 고용보험 가입에 대한 적용이 필요할 것이다.

\section{가. 관광가이드의 고용보험 적용 검토}

관광가이드 직종에서 우선적으로 검토되어야 할 사항은 정부가 추진하는 '전국민 고 용보험 로드맵'에 따라 시행하는 특수형태근로종사자 고용보험 적용 대상13)에 포함하는 방안이다. 관광통역안내사와 관광인솔자들에게는 일정 수준의 근로기간을 통해 해당 기 간이 충족될 경우 실업급여 등의 지원이 가능하도록 고용보험 상 노무제공자로 포섭하

13) 특고 고용보험은 일하는 모든 국민이 고용보험의 혜택을 받을 수 있도록 마련한「전국민 고용보험 로드 맵,에 따라 시행하는 것으로, 기존의 근로자 중심의 고용보험에서 진일보하여 적용대상을 확대하고, 전국 민 고용보험으로 나아가기 위한 핵심단계로 의의가 있다(고용노동부 보도자료, 2021.7.1.) 
는 방안을 마련할 필요가 있다. 예술인 고용보험제도와 같은 형태의 적용이 대표적이라 하겠다. 이를 위하여 우선적으로 관광가이드의 특수고용직에 대한 지위 인정에 대한 의 향조사와 함께, 현재 추진된 12개 직종14)의 고용보험 적용 실시 법제화에 함께 편입되 는 방안이 요구된다.

2021년 한국관광통역안내사협회에서 가입회원을 대상으로 실시한 설문조사 결과, 응 답자의 $97 \%$ 가 고용보험 가입을 희망하는 것으로 나타났다. 응답자의 약 $84 \%$ 가 코로나 19 이전에 관광통역안내사로 활동 경험이 있었고, 약 9\%는 관광통역안내사로 근무시 고용보험 가입 경험이 있는 것으로 나타났다. 특히 주목할 부분은 응답자의 대부분이 향후 관광통역안내사로 근무시 고용보험 가입을 희망한다는 점이다.

[그림 5-4] 관광통역안내사 대상 설문조사 결과

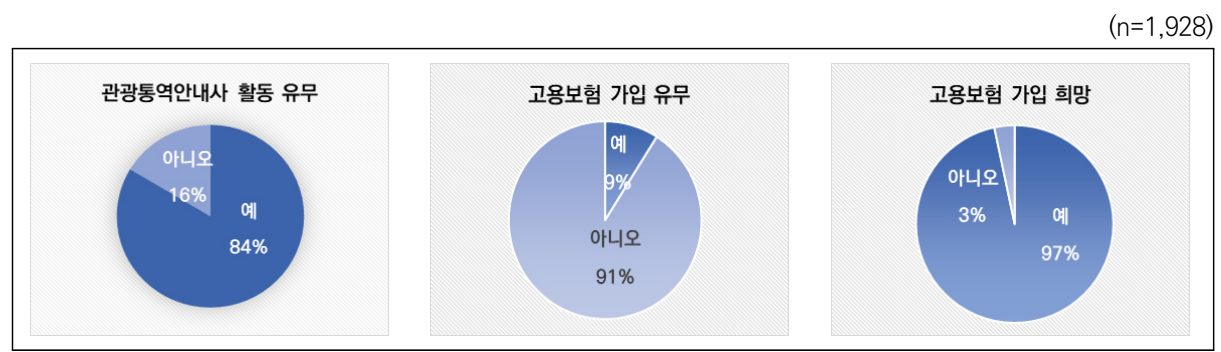

주: 협회 전체 회원수 3,691 명 / 응답 회원수 1,928 명

자료: 한국관광통역안내사협회 내부자료

또한, 한국고용정보원에서 전국민 고용보험 로드맵 적용으로 소득 기반 고용보험제도 개편에 따라 고용보험에 가입하게 될 신청자의 비중을 추산한 결과를 살펴보면, 가전제 품 설치기사, 신용카드회원 모집인 등에서 높게 나타났고, 여가관광 관련 종사원은 61.1\%로 추정되었다(박진희, 2021).

14) (2021년 7월 이후 적용) 보험설계사, 신용카드-대출모집인, 학습지교사, 방문교사, 택배기사, 대여제품방 문점검원, 가전제품배송기사, 방문판매원, 화물차주, 건설기계종사자, 방과후강사 
[그림 5-5] 전국민 고용보험가입 비중 추산 결과

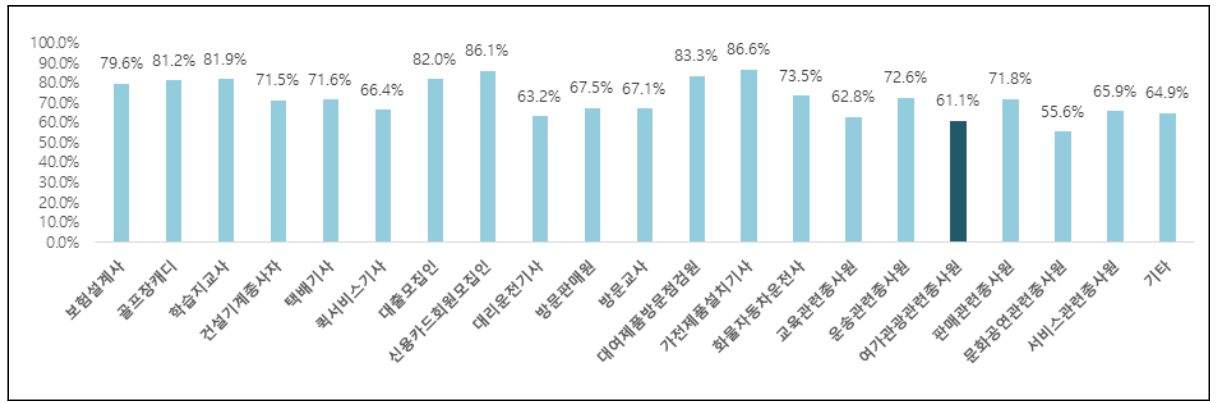

주: 분석 자료는 한국고용정보원, $\mathrm{MDB}$ 를 활용함

자료 출처: 박진희(2021). 행정DB를 이용한 고용보험 사각지대 발굴 및 분석

관광가이드 직종의 고용보험 적용을 위해서는 보호 필요성, 관리가능성, 사회적 영향 력을 종합적으로 고려해야 한다. 우선, 보호 필요성의 관점에서 관광가이드 직종이 갖는 노동시장의 취약성(소득 수준, 여행사와 관광가이드의 관계, 종속성 등)을 고려해야 한 다. 또한 현재 여타 사회보장제도를 통해 지원받지 못하는 사각지대에 놓여있다는 점에 서 고용보험 적용이 필요하다고 볼 수 있다. 다음은 관리 가능성이다. 관광가이드 직종 은 소득 파악이 어렵고, 종사 실태 파악이 미흡한 상황이다. 이러한 배경에서 현재 한국 통역안내사협회에서 '관광통역안내사 실태조사'를 실시하고 있다. 실태조사 결과를 토대 로 대상자를 특정하거나 종사 실태 확인 가능성 등을 구체화 할 수 있을 것이다. 사회적 영향력 관점에서 실태조사 결과를 통해 관광가이드 직종의 규모 파악이나, 사업주의 상 품(서비스) 시장 지배력 등을 검토할 필요가 있다.

특수형태근로종사자 중 특별 직종의 고용보험 가입이 인정되기 위해서는 상시적인 고 용이 유지되다가 고용 불안정 상황에서의 고용보험 지원이 이루어지는 근무조건이 우선 시 되고 있다. 성수기와 비수기가 존재하는 관광산업의 경우, 상시 고용 유지에 대한 여 건이 마련되지 못하여 한계가 있다는 지적도 제기되었다. 관광업계의 특성 상 성수기와 비수기가 존재하기는 하나 인력 중심의 서비스업 전문성 강화, 여행의 일상화 등으로 인해 점차 성수기와 비수기의 편차가 감소되는 점 등을 볼 때 관광가이드 직종의 고용보 험 적용은 필요하다고 할 수 있겠다.

예컨대 예술인고용보험은 월평균소득 50만원 미만의 경우 적용범위에서 제외하고 있 고, 수급요건 또한 이직 전 24개월 중 피보험 단위기간 9개월 이상으로 근로자 고용보험 과 달리 적용하고 있으므로, 직종의 특성을 고려한 접근과 대안 마련이 요구된다. 
고용보험은 소득단절에 대한 사회적 대비이고, 개인의 선택에 따라 가입 여부를 결정 할 수 있는 문제는 아니다. 관광가이드를 특고 적용 직종에 편입해야 한다면 매달 납부 해야 하는 보험료 부담을 어떻게 조정할 수 있는지를 논의해야 한다. 실제로 저소득층의 사회보험료를 국가가 지원하는 사례가 있기 때문에 대안을 찾는 것이 필요하다.

\section{나. 영세업체의 고용안전망 강화를 위한 지원}

여행업과 같은 현재 고용안전망이 필요한 업종뿐 아니라 영세한 관광업종의 고용안전 망 편입을 위해서는 보다 빠른 정책 편입을 위한 혜택 및 지원이 요구된다. 고용보험의 적용대상이나 미가입 종사자, 즉 실질적 사각지대를 해소하기 위한 정책적 노력이 필요 한 시점이다. 이를 위해서는 관광산업의 자체 재원을 마련하여 지원을 강화하고, 향후 전국민 고용안전망에 편입되기 위한 확대 체계를 마련할 필요가 있다.

현재 정부는 소규모 영세사업장인 근로자 10명 미만 사업자 대상 월평균 보수 215만 원 이하 근로자와 사업자에게 국민연금과 고용보험료의 최대 $90 \%$ 를 지원하는 두루누리 보험료 지원제도를 운영하고 있다. 관광사업체의 영세한 규모와 특성을 고려한다면, 두 루누리 보험료 지원제도와 같은 비용 지원을 통하여 고용보험 가입을 독려하는 방법이 가능할 것이다. 재원의 경우, 관광사업 종사자들이 참여하는 고용안정 재원을 마련하고, 이후 용도에 대하여 관광산업 종사자 고용안전망 지원제도를 통해 두루누리 보험료 지 원제도의 형태로 운용을 하는 것도 대안이 될 수 있다.

\section{〈두루누리 사회보험료 지원사업〉}

$\square$ 사업개요

- 소규모 사업을 운영하는 사업주와 소속 근로자의 사회보험료(고용보험·국민연금)의 일부를 국가에서 지원 함으로써 사회보험 가입에 따른 부담을 덜어주고, 사회보험 사각지대를 해소하기 위한 사업

$\square$ 지원대상

- 근로자 수가 10 명 미만인 사업에 고용된 근로자 중 월평균보수가 210 만원 미만인 근로자와 그 사업주에 게 사회보험료(고용보험·국민연금)를 최대 $90 \%$ 까지 각각 지원

* 2018년 1월 1일부터 신규지원자 및 기지원자 지원을 합산하여 3년(36개월)만 지원(기지원자의 경우 2020년까지 지원, 2021년부터 지원 중단)

$\square$ 지원수준

- 신규지원자 : (고용보험료) 지원신청일 직전 1년간 피보험자격 취득이력이 없는 근로자와 그 사업주 (국민연금보험료) 2018.1.1. 이후 국민연금 최초 가입자 또는 지원신청일 직전 1년간 사업장 가입이력이 없는 자 ${ }^{*} 5$ 명 미만 사업 $90 \%$ 지원 /5명 이상 10 명 미만 사업 $80 \%$ 지원)

- 기지원자 : 신규지원자에 해당하지 않는 근로자와 사업주(*10명 미만 사업 $40 \%$ 지원)

자료: 두루누리 사회보험료 지원사업 웹사이트(http://insurancesupport.or.kr/durunuri/intro.php) 
또 다른 방법은 공제회의 형태로 고용안전망의 재원을 마련하는 것이다. 공제회는 단 체 구성원들이 일정 금액을 각출하여, 구성원들이 질병이나 상해 등 사고가 발생하였을 때, 정해진 금액을 지급하게 되는 형태인데, 관광진흥법 상 업종의 사업자 및 종사자들 이 가입하는 공제회를 구성하고, 이에 대한 일정 부분의 사용처에 정부 지원이 합해지는 방식이다. 예컨대 건설근로자 휴가비 지원의 경우 건설근로자공제회지원금과 함께 정부 지원금이 합하여 지원이 이루어지고 있는 것과 유사한 방식이다. 궁극적으로는 현재 정 부에서 논의되고 있는 전국민 고용안전망의 형태로 관광산업 고용안전망이 편입되게 되 는 과정이 필요할 것이다.

\section{〈건설근로자 퇴직공제제도〉}

$\square$ 사업개요

- 일용·임시직 건설근로자가 퇴직공제 가입 건설현장에서 근로하면 건설사업주가 공제회로 근로일수를 신고 하고 그에 맞는 공제부금을 납부하면 해당 근로자가 건설업에서 퇴직할 때 공제회가 퇴직공제금을 지급하 는 제도

$\square$ 건설근로자 퇴직공제금

- 일용·임시직 건설근로자가 건설업에서 퇴직할 때 받을 수 있는 돈으로서, 퇴직공제 가입현장에서 근로한 일수에 맞게 적립된 공제부금에 이자를 더하여 지급하는 금액

※ 단, 적립일수 252 일 이상이거나 만 65 세 이상인 근로자가 청구하는 경우에만 지급

$\square$ 퇴직공제 가입공사의 범위

- 건설, 전기, 정보통신, 소방, 문화재수리 공사로서 공사예정금액 1억원 이상 공공공사, 공사예정금액 50 억 원 이상 민간공사는 퇴직공제에 가입하고 근로자들에게 퇴직공제 혜택 제공

$\square$ 적용대상 근로자의 범위

- 퇴직공제 가입현장에서 근로하는 근로계약기간 1년 미만 일용, 임시직 근로자

$※$ 근로자의 국적, 연령, 소속 및 직종 에 제한 없이 적용

자료: 건설근로자공제회 웹사이트(https://www.cw.or.kr/contents.do)

\section{다. 고용유지지원제도 및 특별고용지원제도 보완}

코로나19가 장기화되면서 관광업계의 고용불안은 당분간 이어질 것으로 예상된다. 고 용노동부는 2021년 제5차 고용정책심의회에서 특별고용지원 업종에 대한 유급고용유지 지원금 지원기간을 현행 180 일에서 90 일을 추가로 지원하는 연장안을 심의-의결했다. 이에 따라 항공업·여행업 등 특별고용지원 업종15) 사업장들은 기존 지원 일수 180 일에

15) 특별고용지원 업종(15개): 조선업, 여행업, 관광숙박업, 관광운송업, 공연업, 항공기취급업, 면세점, 전시국제회의업, 공항버스, 영화업, 수련시설, 유원시설, 외국인전용카지노, 항공기부품제조업, 노선버스 
90일을 추가하여 2021년에도 270일간 유급휴업·휴직 지원을 받을 수 있게 되었다16).

\section{〈고용유지지원제도 개요〉}

$\square$ (개요) 일시적 경영난으로 고용조정이 불가피하게 된 사업주*가 휴업·휴직 등 고용유지 조치를 하는 경우 인건비 일부 지원

* 재고량 $50 \%$ 증가, 생산량-매출액 $15 \%$ 이상 감소 등

* 코로나19로 인한 집합제한 금지 사업장은 고용조정이 불가피한 사업주로 인정( ‘21.6.30)

$\square$ 지원요건

- 유급 고용유지지원금 (1)휴업: 피보험자 전체 소정근로시간 합계 대비 $20 \%$ 초과하여 단축, (2)휴직: 1개월 이상 휴직 부여

- 무급 고용유지지원금

(1)무급휴업: (A)30일 이상 실시, B)일정 규모* 이상 무급휴업 실시, (C)노동위원회 승인

* $\ 50 \%$ 이상 (19인 이하), \10명 이상 (99명 이하), \10\% 이상 (100명 999명), \100명이상 (1,000명 이상)

(2)무급휴직: (A)30일 이상 실시, B)일정 규모* 이상 무급휴직 실시, (C)무급휴직 1년 이내 3개월** 이상 유급휴업 또는 피보험자 $20 \%$ 이상 휴직 실시, (D)근로자대표 합의

* \10명 이상 (99명 이하) \10\% 이상 (100명 999명) \100명 이상 (1,000명 이상)

** 특별업종은 무급휴직 전 1년 이내에 1개월 이상 유급휴업 또는 피보험자 $20 \%$ 이상 유급휴직 실시

$\square$ 지원금액

\begin{tabular}{|c|c|c|c|c|}
\hline \multirow{2}{*}{ 구분 } & \multicolumn{2}{|c|}{ 유급 휴업·휴직 고용유지지원금 } & \multicolumn{2}{|c|}{ 무급 휴업·휴직 고용유지지원금 } \\
\hline & 지원수준 & 지원한도(기간) & 지원수준 & 지원한도(기간) \\
\hline 일반업종 & $\begin{array}{l}\text { ·우선지원 } 2 / 3 \\
\text {-대규모 } 1 / 2 \text { 또는 } \\
2 / 3^{*} \text { (*단축율 } 50 \% \text { 이상) }\end{array}$ & $\begin{array}{l}\cdot \text { 우선지원(대규모) } \\
\text { 1일 6.6만원(연 180일) }\end{array}$ & $\begin{array}{l}\text {-평균임금의 } 50 \% \text { 범위 } \\
\text { 내에서 심사위원회 결 } \\
\text { 정 }\end{array}$ & $\begin{array}{l}\text { ·우선지원(대규모) } \\
\text { 1일 6.6만원 } \\
\text { (최대 180일) }\end{array}$ \\
\hline $\begin{array}{l}\text { 특별업종 } \\
\text { 고용위기 } \\
\text { 지역 }\end{array}$ & $\begin{array}{l}\cdot \text { 우선지원 } 9 / 10 \\
\text { ·대규모 } 2 / 3 \text { 또는 } \\
3 / 4^{*} \text { (*단축율 } 50 \% \text { 이상) }\end{array}$ & $\begin{array}{l}\text { ·우선지원 1일 7만원 } \\
\text { ·대규모 1일 6.6만원 } \\
\text { (연 180일) }\end{array}$ & $\begin{array}{l}\text { ·평균임금의 } 50 \% \text { 범위 } \\
\text { 내에서 심사위원회 결 } \\
\text { 정 }\end{array}$ & $\begin{array}{l}\text { ·우선지원(대규모) } \\
\text { 1일 6.6만원 } \\
\text { (최대 180일)* }\end{array}$ \\
\hline
\end{tabular}

정부의 고용지원 대책은 기업과 근로자, 실직자 등 정책 수혜자에게 실질적인 도움이 될 수 있도록 현장의 의견을 지속적으로 수렴하며 보완해나갈 필요가 있다. 고용유지지 원금 수급 현황 분석 결과 여행업의 10 $12 \%$ 가 지원을 받고 있다는 것과 인터뷰 과정에 서 논의된 것처럼 영세업체의 경우 사업자 부담금 $10 \%$ 도 어려운 상황이라는 점은 현재 관광업계가 처한 현실을 보여준다.

고용보험의 사각지대에 있는 긴급고용안정지원금 수급 관련 근로활동 내역에 대한 증 빙의 어려움, 표준계약서 작성 미이행 등도 개선이 필요하다.

16) 특별고용지원 업종은 유급고용유지지원금이 종료되어도 270 일간 무급휴업·휴직지원금 지원이 가능하다. 
관광산업 내부적으로 인력에 대한 구조조정이 지속될 것으로 예상되므로 이에 대한 고려도 필요하다. 고용유지, 생활안정, 재취업 지원으로 이어지는 고용지원 프로그램을 통하여 산업별 특성에 맞는 고용 지원을 강화할 필요가 있다. 사업주가 선택할 수 있는 다양한 형태의 고용유지 지원 제도 마련을 요구할 필요가 있다.

해외사례에서 제시한 노동시간 단축, 일자리 나누기 정책 시행시 근로자 임금감소분 에 대한 지원 등을 확대 적용할 필요가 있다.

〈표 5-1〉 정부의 고용유지지원 제도

\begin{tabular}{|c|c|c|}
\hline 구분 & 지원 요건 & 지원 내용 \\
\hline $\begin{array}{l}\text { 고용안정 협약 } \\
\text { 지원금 }\end{array}$ & $\begin{array}{l}\text { - 노사가 휴업, 휴직, 근로시간 단축, 임금 삭 } \\
\text { 감 등의 임금 감소에 합의 } \\
\text { - 매출액 또는 생산량 } 15 \% \text { 이상 감소 }\end{array}$ & $\begin{array}{l}\text { - 근로자 } 1 \text { 인당 월 } 50 \text { 만원 한도 내에서 } \\
\text { 임금 감소분의 최대 } 50 \% \text { 지원 } \\
\text { - 최장 } 6 \text { 개월 }\end{array}$ \\
\hline $\begin{array}{l}\text { 무급휴직 } \\
\text { 신속지원 } \\
\text { 프로그램 }\end{array}$ & $\begin{array}{l}\text { - 노사 합의로 } 1 \text { 개월 이상 유급휴업하고 } 30 \text { 일 } \\
\text { 이상 무급휴직 실시 } \\
\text { - 매출액 또는 생산량 } 30 \% \text { 이상 감소 }\end{array}$ & $\begin{array}{l}\text { - 무급휴직자 1인당 월 } 50 \text { 만원 } \\
\text { - 최장 } 3 \text { 개월 }\end{array}$ \\
\hline $\begin{array}{c}\text { 무급휴직 } \\
\text { 고용유지지원금 }\end{array}$ & $\begin{array}{l}\text { - 노사 합의로 3개월 이상 유급휴업하고 90일 } \\
\text { 이상 무급휴직 실시 } \\
\text { - 매출액 또는 생산량 } 30 \% \text { 이상 감소 }\end{array}$ & $\begin{array}{l}\text { - 무급휴직자 } 1 \text { 인당 월 } 198 \text { 만원 한도 } \\
\text { 내에서 평균 임금의 최대 } 50 \% \text { 지원 } \\
\text { - 최장 } 6 \text { 개월 }\end{array}$ \\
\hline
\end{tabular}

자료: 고용노동부

또 다른 쟁점은 특별고용지원 업종의 지원기간이다. 코로나19 팬데믹의 영향이 장기 화되면서, 종식 시점이 불투명한 상황이다. 방한 외래관광객을 대상으로 하는 관광사업 체의 경우, 회복 시점 역시 불분명한 상황으로, 특별고용지원 업종의 지원기간을 연장하 는 업계의 요구사항을 고려할 필요가 있다.

\section{「특별고용지원 업종의 지정기준 등에 관한 고시」}

제6조(지원기간) (1) 특별고용지원 업종의 최초 지원기간은 2 년의 범위 내에서 고용정책심의회의 심의를 거쳐 정한다. (2) (3) (생략)

제7조(지원기간 연장) (1) 업종별단체등은 특별고용지원 업종 지원기간의 연장이 필요한 경우 제3조제1항 각 호의 자료와 그간 지원기간 동안의 운영 성과 및 평가 자료를 첨부하여 지원기간의 만료 2 개월 전까지 고용노 동부장관에게 지원기간의 연장을 신청하여야 한다.

(2) 고용노동부장관은 제2조에 따른 지정기준 등을 고려하여 고용정책심의회 심의를 거쳐 특별고용지원 업종

의 지원기간을 각 1 년의 범위 내에서 2 회에 한해 연장할 수 있다.

(3) (4) (생략) 


\section{2. 업종별·고용형태별 특성을 고려한 사각지대 해소}

전반적인 관광산업의 고용안전망 흐름에 대한 대응뿐 아니라 업종별, 고용형태별 다 양한 고용 사각지대가 존재하는 만큼 이에 대한 대응도 필요하다. 관광진흥법상 관광사 업 중 본 연구에서 중점적으로 검토한 업종은 여행업, 관광숙박업, 국제회의기획업이다. 본 연구에서는 심층인터뷰 분석 결과와 관련 현황 자료를 종합하여 업종별 사각지대 해 소를 위한 과제를 제안하였다.

\section{가. 여행업}

여행업은 노동 유연성 문제, 계절성 및 관광시장의 변화 등이 주로 이루어지는 업종이 다. 이에 따라 기존 여행업 종사자들의 경우에도 상당한 고용불안정을 겪고 있으며, 코 로나19 이후 전환이 이루어지거나 전환을 고려하는 경우도 많은 실정이다. 관광통역안 내사 및 국외여행인솔자 등은 프리랜서 활동 비중이 높기 때문에 이들에 대한 관광지원 정책이 실질적으로 반영이 되지 않는 경우도 많다.

랜드사 등의 경우 1 인, 소규모 자영업자, 가족들이 무급으로 업무를 도와주는 경우도 존재하여 관광위기 시 심각한 고용위기를 겪고 있는 실정이다. 이를 위하여 사회보험료 지원 제도 등을 통하여 안정적으로 고용보험을 적용받을 수 있도록 유도할 필요가 있다. 전국민고용보험 로드맵 상 자영업자는 2025년 이후 사회적 논의를 통해 추진 예정이다. 다만, 현재도 자영업자의 생활안정 및 재취업을 지원하기 위해 자영업자 고용보험제도를 운영하고 있고, 본인이 희망하는 경우 임의가입이 가능하다. 고용안전망 체계로 점진적 으로 여행업종 종사자 전체가 제도권 내로 유입될 수 있도록 지원을 확대할 필요가 있다.

이외에도 기존 단순 직무를 수행하는 여행업 종사자들은 직무 재교육, 창업 및 창직 교육 등을 통해 원활한 고용 전환을 준비하여야 할 것이다. 최근 늘어나는 OTA 등 관광 플랫폼 분야와 연관된 종사자 역시 고려할 대상이다. 1 인 가이드 형태로 OTA 플랫폼을 통해 활동하는 가이드와 $\mathrm{OTA}$ 를 통해 체험상품을 판매하는 종사자 역시 관광업종으로의 편입 및 고용안전망 확대시 함께 적용되어야 한다. 


\section{나. 관광숙박업}

관광숙박업은 대규모 숙박업종과 중소규모 숙박업종의 상황이 다르게 나타난다. 대규 모 숙박업종은 업무 영역에 따라 외주협력업체에 위탁 운영하는 방식이 활발히 진행되 고 있다. 하우스키핑, 시설 관리, 식음 부서 등 고객과 직접 대면하지 않는 업무 영역은 외주협력사 직원이 담당하고, 프론트 등 고객과 직접 대면 서비스 영역은 정규직이 담당 하는 추세이다. 17) 실제 호텔업 객실 종사자 기준으로 살펴보면, 용역업체 소속 종사자 비율이 38.5\%로 높게 나타나며, 이러한 현상은 5성급 호텔(51.5\%)에서 더욱 뚜렷하게 나타난다.

[그림 5-6] 2019년 기준 호텔업 종사자 고용형태(객실 종사자 기준)

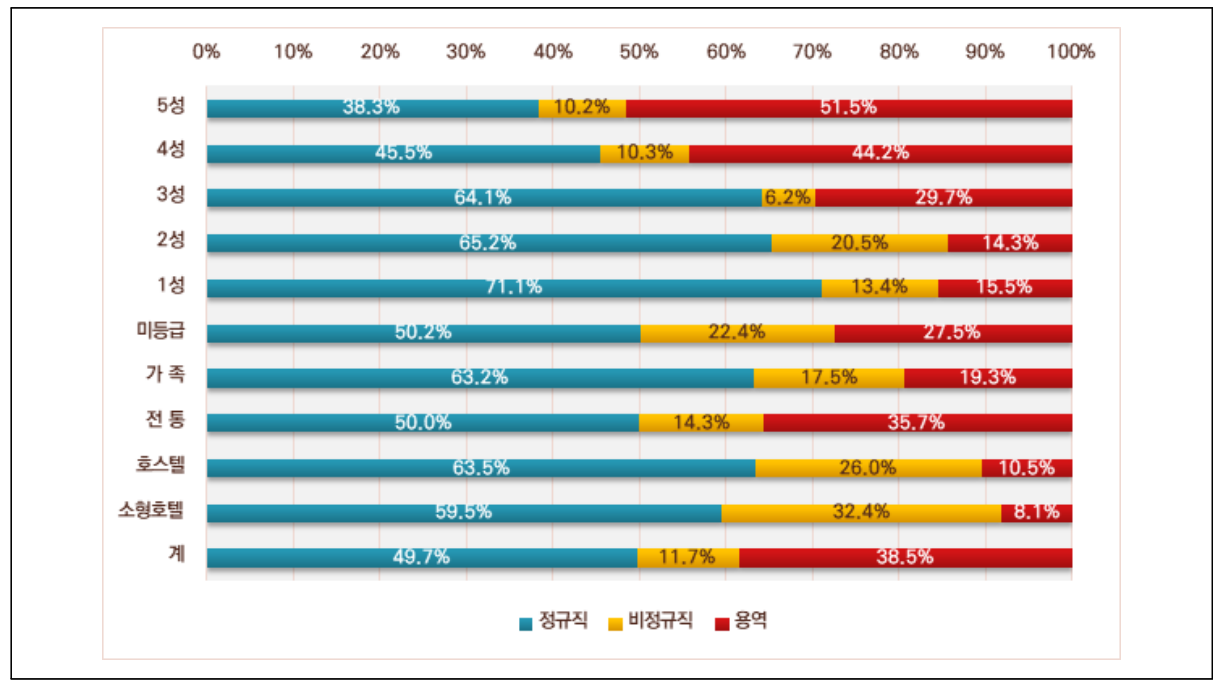

주1) 정규직 : 사용자와 직접 근로계약을 체결하여 사업장 내에서 전일제(full-time)로 근무하면서 근로계약기간의 정함이 없이 정년까지 고용이 보장되는 근로자

주2) 비정규직 : 일정한 기간의 노무급부를 목적으로 사용자와 근로자가 한시적으로 근로관계를 맺는 모든 비조직화 된 고용 형태(기간제근로, 단시간근로/파트타임, 파견근로 등)

주3) 용역 : 거래의 대상이 상품이 아닌 서비스(용역)를 위탁받아 전문적으로 관리하는 업체의 근로자

자료: 한국호텔업협회(2020). 2019년 호텔업 운영현황

17) 호텔업의 조직은 고객과의 접촉 여부에 따라 전방과 후방부문으로 구분한다. 전방 부문은 접객부서로서 일선에서 직접 고객에게 상품을 제공하고 판매를 담당하는 객실, 식음료 등으로 호텔의 직접적인 매출이 발생하는 분야이며, 후방 부문은 고객과의 직접적인 접촉이 없으면서 고객을 접객하는 부서의 업무를 지 원하는 역할을 담당한다(오계택 외, 2017; 유규창, 2005). 
이 같은 외주화는 구조적으로 근로자가 취약 할 수 있겠지만 현행 법 상 고용보험 가 입대상으로, 외주협력업체 근로자 지위 자체가 제도적 사각지대에 놓여있는 것은 아니 다. 다만, 고용상의 지위는 상당히 위태로운 것이 사실이다. 외주협력업체는 숙박 대기 업의 자회사 또는 외주회사로 운영이 되며 고용보험 등의 가입은 되어 있으나, 외주협력 업체의 폐업이나 위탁업체 교체를 통해 고용에 대한 불안정성이 큰 문제점이 존재한다. 또한 외주협력업체는 관광업종이 아닌 경우가 있어, 관광위기상황에서의 관광업종 지원 의 혜택을 받을 수도 없는 실정이다.

중소규모 관광숙박업의 경우 각 기업에서는 정규직이 아닌 대부분 계약직, 임시직, 일 용직, 초단시간 근무자 등의 고용을 통해 상황에 따라 고용의 탄력성을 꾀하는 경우가 많다. 이에 따라 고용의 불안정성과 함께 노동의 전문성 확보도 어려운 실정이다. 숙박 의 경우에도 최근 OTA 플랫폼 운영이 활성화되고 있는데 이에 따라 기존 숙박업의 홍보 마케팅, 예약분야가 OTA 플랫폼 노동자에게 사실상 외주화가 되는 경우가 존재한다. 그럼에도 OTA 플랫폼 노동자들은 관광업종의 지원 대상에서 제외되고 있다. 이러한 숙 박업의 외주화는 결국 관광산업이 주로 기대하는 일자리 창출효과 등이 점차 감소되는 부정적 영향을 미치기도 한다.

따라서 관광숙박업 사업자가 직접고용을 증대시켜 고용의 질을 강화할 수 있는 적극 적 제도 설계가 요구된다. 현재의 관광업종 고용구조는 지속적으로 직접 고용에서 간접 고용으로 변화하는 과정을 겪고 있다. 이러한 형태가 지속될 경우 관광업종의 전문성 약화뿐 아니라 고용에 대한 불안정성 증대가 지속될 가능성이 존재하여 표면적으로 드 러나지 않았으나 매우 심각한 관광업의 잠재적 위기를 가져올 가능성이 크다. 따라서, 현재 관광업계 지원 정책 설계시 사업자의 매출, 자산 및 담보 등의 사업자 측면의 상황 만을 고려할 것이 아니라, 고용에 대한 관리 분야를 강화할 필요가 있다. 실례로 관광진 흥개발기금 융자 지원시 고용에 대한 정책적 고려가 되지 않고 있는데, 고용창출효과 등을 고려하여 선별적 가산점을 부여하는 등의 직접 고용에 대한 제도적 지원을 강화할 필요가 있다. 관광숙박 정책에서 호텔업 등급 평가기준도 시설 및 서비스 기준 뿐 아니 라 고용안전망에 대한 지표, 예컨대 직접고용 비중 등을 포함하여 양질의 고용구조를 갖추고 있는 경우 가점을 부여하는 방안 등이 가능할 것이다. 


\section{다. 국제회의기획업}

국제회의업은 국제회의시설업과 국제회의기획업으로 구분하는데, 국제회의시설업은 비교적 규모가 크거나 공공기관과 연관된 기업에서 수행하기 때문에 비교적 고용안전망 이 잘 갖추어진 반면, 국제회의 개최를 기획하는 국제회의기획업( $\mathrm{PCO})$ 은 대부분 영세하 고, 국제회의 개최 기간에만 일하는 형태가 많기 때문에 프리랜서, 일용직, 초단시간 근 무자로 고용이 이루어지고 있다.

다만 PCO의 경우, 일정 부분 근무한 경력자들이 자발적 프리랜서로의 전환하는 경우 가 많고, 업종 특성상 여성이 많은데 결혼, 출산, 육아 등의 경력단절 문제로 인하여 프 리랜서로 전환되는 경우가 적지 않은 편이다. 경력단절 여성 프리랜서에 대한 실태 조사 를 통해 근로 여건 파악이 필요하다고 판단된다. 또한 직접 고용은 이루어지지만 고용보 험 적용이 되지 않거나, 일자리가 불안정한 단기 근로자를 양산하는 경우가 존재하는데, 이에 대하여 고용보험제도 편입을 유도할 필요가 있다.

다른 관광업종의 경우에는 이러한 실태나 규모조차 파악이 어려운 상황이다. 코로나 19 상황에서의 고용 관련 지원책으로 인하여 여러 고용관련 실태조사 파악이 이루어진 부분은 존재하나 일회성 조사로서 지속적인 근무자 파악이 되지 않고 있다. 따라서 고용 실태조사에 대한 지속적인 시행과 관광분야 인력 데이터베이스 확보가 선행될 필요가 있다.

\section{라. 위탁용역업체}

관광숙박업은 위탁 및 외주협력 등의 하도급 계약을 통해 타사업체의 파견을 통해 고 용이 영위되는 경우가 많다. 관광숙박업의 외주화는 용역업체를 통해 근로자로 채용하는 이상 고용보험 가입이 적용되기 때문에 그 자체로 고용안전망의 사각지대로 내몰리는 것은 아니다. 다만 구조조정에서 취약해지는 문제가 발생할 수 있다.

외주화로 인해 고용안전망의 사각지대는 관광업계의 위기 상황에서 정부 지원이 이루 어진다 하더라도 외주 협력업체가 관광진흥법상의 관광업종으로 분류되지 않아 혜택이 적용되지 않거나 외주협력사 소속 근로자들은 지원대상에서 제외되는 경우가 적지 않기 때문에 발생한다. 
따라서 외주협력업체 사업주 신고 등을 통해 이를 인정할 수 있는 체계 마련이 필요하 다. 대표적으로는 건설업의 경우 건설현장 소재지관할 고용센터에 하수급인 자료가 의무 제출사항인데, 이러한 형태를 통해 숙박업종의 하도급 고용지원의 근간을 마련할 수 있 을 것으로 기대된다. 또한 위탁 및 외주협력업의 경우 관광숙박업과의 계약 및 인력파견 이 매출의 상당수를 차지한다면 관광편의시설업(관광지원서비스업)으로의 등록을 유도 할 필요도 있다. 관광숙박업이 점차 외주화가 가속화되는 상황에서 이에 대한 대응은 관광숙박업 고용의 질 강화에 매우 중요한 요소이기 때문이다.

\section{마. 임시일용직}

관광숙박업과 국제회의기획업은 임시직, 일용직, 초단시간 근무자의 비중이 많은 특 성도 존재한다. 결국 질 좋은 고용과 일자리 창출이 어려운 현재의 구조를 개선하기 위 해서는 일정 부분 관광숙박업 및 국제회의기획업 지원 시 정규직과 계약직의 비중을 고 려하는 등 고용지표를 마련하여 이를 적용할 필요도 있다.

중소사업체의 경우 종사자 고용을 안정적으로 확대할 수 있는 지원체계 마련이 요구 된다. 예컨대 호텔업 중 3성급 이하 중소규모의 관광호텔은 매우 적은 정규직 인력과 나머지 인력은 임시직, 일용직, 초단시간 근무자로 운영될 가능성이 높다. 이에 대한 고 용확대 정책을 호텔 등급제나 융자 지원과 함께 연동할 필요성이 존재한다.

관광업종은 1 인 자영업자 및 가족 고용 형태도 적지 않은 영세성을 지니고 있다. 이들 의 경우 대부분 고용이나 산재보험 가입이 되지 않기 때문에, 고스란히 관광위기 시 폐 업이나 실직의 부담을 겪고 있다. 현재 근로복지공단의 자영업자 고용보험 가입자 중 소상공인시장진흥공단 등을 통해 1 인 자영업자 고용보험료 지원사업이 실시되고 있는 데, 관광업종을 위한 확대 등을 검토할 수 있을 것이다. 그 밖에 영세한 관광객이용시설 업, 관광편의시설업 등이나, 관광진흥법 상 7대 관광업종이 아닌 관광 유관시설의 경우 이러한 문제점이 파악조차 되지 않고 있는 실정이다. 이를 위해 지속적인 모니터링과 실태 파악이 필요하다. 


\section{3. 관광종사자의 전문성 강화}

\section{가. 관광종사자 재교육-재취업 지원}

고용안전망은 고용의 질적 강화와도 밀접한 관련이 있다. 종사자의 직무 전문성 강화 는 곧 고용 안정으로 이어지기 때문이다. 관광산업의 급격한 환경 변화에서 기존 고용된 근로자 역시 직종 전환 등의 상황이 필요할 경우 적극적으로 정부에서 대응하여 고용 불안전성을 미연에 방지할 필요도 있다. 따라서 관광인력 정책에서 종사자 재교육을 확 대·강화할 필요가 있다. 기존 인력 교육은 재직자 중심의 직무역량 강화에 초점을 두고 업종별 직무교육 프로그램을 추진하고 있다. 해외 시례에서 공통적으로 나타난 것처럼 종사자의 직무 숙련도 향상 프로그램을 마련하고, 디지털 기술 역량 강화 프로그램을 확대하는 조치가 필요하다.

〈표 5-2〉 업종별 주요 교육현황(2021년)

\begin{tabular}{|c|c|c|}
\hline \multicolumn{2}{|r|}{ 업종 } & 교육명 \\
\hline \multirow[b]{2}{*}{$\begin{array}{l}\text { 여 } \\
\text { 행 } \\
\text { 업 }\end{array}$} & 여행업종사자 & - 국외여행인솔자 직무교육, 여행안전관리 및 역량강화, 여행업 노무 교육 \\
\hline & $\begin{array}{l}\text { 안내사/통역 } \\
\text { 안내사/해설사 }\end{array}$ & $\begin{array}{l}\text { - 신입실무, 역량강화교육, 소수언어 양성/실무교육 등 } \\
\text { - 테마아카데미(한국사, 고궁, 음식관광, DMZ관광, 무슬림관광 등), } \\
\text { 지역전문가과정(도 단위별), 프리미엄교육(DMZ/럭셔리/종교) }\end{array}$ \\
\hline \multicolumn{2}{|r|}{ 관광숙박업 } & - 호텔 경영책임자교육, 종사자 분야별 특성화교육, 객실관리 전문인력 양성 등 \\
\hline \multicolumn{2}{|r|}{ 국제회의업 } & $\begin{array}{l}\text { - 신입사원 OJT,재직자전문가, 중견관리자 양성, Young MICE 리더 프로젝트 } \\
\text { - 대형행사 현장 안전관리교육, MICE안전관리 }\end{array}$ \\
\hline \multicolumn{2}{|r|}{ 유원시설업 } & - 일반유원시설 안전관리자 양성, 안전교육, 물놀이형 유원시설 안전요원 교육 등 \\
\hline \multicolumn{2}{|r|}{ 카지노업 } & - 자금세탁방지(AML)·테러자금조달금지(CFT)실무 \\
\hline
\end{tabular}

자료: 문화체육관광부 한국문화관광연구원(2021). 관광R\&D 중장기 기술로드맵 수립 연구

각 업종마다 관광위기 상황에서 실직을 하는 경우, 재취업의 기회를 마련하거나, 관광 사업 창업 등을 지원하기 위한 교육훈련제도의 마련이 요구된다. 한국관광공사에서 운영 하는 관광인 사이트는 관광사업 일자리 정보와 취업 컨설팅, 교육에 대한 자격증 발급 등을 시행하고 있다. 고용과 관련한 기초정보 마련, 각종 지원제도에 대한 연계 등을 통 해 관광인 사이트를 활성화하고, 실질적인 재취업을 위한 안전망 확보를 구축하여야 할 것이다. 
관광일자리 정책은 전문 인력 양성이 중심을 이루고 있다. 관광산업정책과 업무는 관 광 전문 인력 양성 및 취업지원에 관한 사항, 관광종사원의 교육, 관광자격제도 운영 및 개선에 관한 사항으로 명시하고 있다. 지금까지 국내 관광산업의 인력양성은 관광기업 중심의 인력 양성과 직무교육에 초점을 두고 추진되었다. 최근에는 관광산업의 디지털 기술 활용이 대두되면서 관광종사자의 기술역량 강화 사업이 추진되고 있다. 고용안전망 의 기능을 강화하기 위해서는 재직자 중심의 교육 지원 사업 추진을 강화할 필요가 있다. 나아가 향후 미취업자 및 실업자 대상 교육 서비스 확충이 요구된다.

〈표 5-3〉 문화체육관광부의 주요 관광 인력 교육 프로그램(2021년)

\begin{tabular}{|c|c|c|}
\hline 구분 & 사업명 & 내용 \\
\hline \multirow{4}{*}{$\begin{array}{l}\text { 학교 } \\
\text { 교육 }\end{array}$} & 우수호텔 아카데미 육성 및 지원 & 우수호텔아카데미 기관 공모 및 교육운영 지원 \\
\hline & 미래형 관광인재 육성('20년 ) & $\begin{array}{l}\text { '20년 ICT융합인재양성 교육모델 개발(대학 공모) 및 교육 } \\
\rightarrow \text { '21년 미래관광인재육성센터(교육장) 활용 교육 }\end{array}$ \\
\hline & 관광고교 교사 및 학생 대상 교육 & 전국 특성화고교 대상 취업 포럼 \\
\hline & $\begin{array}{c}\text { 지역 대학생 대상 } \\
\text { 관광나래오픈캠퍼스 운영 }\end{array}$ & $\begin{array}{l}\text { (내용) 지역관광 인재 양성(국내외 관광트렌드 및 스마트 관 } \\
\text { 광 활용사례, 관광벤처 기업 창업과정 및 성공사례, 관광현 } \\
\text { 장 체험 등) }\end{array}$ \\
\hline \multirow{2}{*}{$\begin{array}{l}\text { 신직무 } \\
\text { 양성 }\end{array}$} & 신중년 관광일자리 창출 지원사업 & 신중년 대상 신직무 기반 교육과정 설계 및 교육생 모집·선발 \\
\hline & 개별관광전문가이드 육성(‘20년 ) & $\begin{array}{l}\text { 창업실무·디지털마케팅 교육, 맞춤형 컨설팅 제공, 신직무 } \\
\text { (로컬크리에이터, 시니어여행 코디네이터 등) }\end{array}$ \\
\hline \multirow{8}{*}{$\begin{array}{l}\text { 재교육 } \\
\mathrm{HRD}\end{array}$} & 관광산업 이러닝 서비스 & 이러닝 교육과정 지속 확충, 플랫폼 홍보, 운영 및 관리 \\
\hline & 관광공무원 및 RTO 교육 & 관광정책 기획 및 운영을 위한 전문직무역량 \\
\hline & 빅데이터 활용 교육사업(‘21년 ) & 관광 Data Lab 활용 빅데이터 이해·분석, 실무 적용 등 \\
\hline & 문화관광해설사 교육 및 관리 & 문화관광해설사 교육, 신규 양성, 제도홍보 등 \\
\hline & 관광안내서비스 활성화 지원 & 관광안내서비스 활성화 및 미래 인재 육성 컨설팅 \\
\hline & 개별여행객 맞춤형 교육 & $\begin{array}{l}\text { 관광통역안내사 대상 전문역량 강화 교육, 관광거점도시 현 } \\
\text { 장·실습 이러닝 콘텐츠 제작·배포 }\end{array}$ \\
\hline & 관광산업 이러닝 서비스 & 이러닝 교육과정 지속 확충, 플랫폼 홍보, 운영 및 관리 \\
\hline & 재직자 전문 교육 & $\begin{array}{l}\text { 여행업, 호텔업, MICE, 유원시설업, 카지노업, 관광스타트 } \\
\text { 업 등 종사자 대상 직무 역량 교육 }\end{array}$ \\
\hline
\end{tabular}

자료: 문화체육관광부·한국문화관광연구원(2021). 관광R\&D 중장기 기술로드맵 수립 연구 


\section{다. 관광종사원 자격제도 정비와 연계한 고용의 질 강화}

관광산업 종사자에게 필요한 자격제도의 경우 자격제도 자체가 보다 고용안전망을 높 일 수 있는 실질적 제도가 되어야 하는데 현재로서는 유명무실한 제도로 전락하고 있다. 따라서 고도화된, 숙련된 서비스 영역에 대한 기준을 높이기 위해서는 자격제도에 대한 정비와 연계한 고용의 질 보장이 요구된다. 예컨대, 도시계획기술사의 경우 도시 계획 전공자만 응시 가능하도록 장벽을 높여서 관리하거나, 부동산중개업의 경우도 부동산 공 인중개사 자격증 취득 이후 경력 설계가 가능한 구조로 재편되고 있다. 관광업계의 자격 제도 역시 서비스 품질 관리 측면에서 정비가 필요하다. 관광산업 고용인력의 외주화 및 위탁용역 전환 흐름을 막을 수는 없지만, 최소한 인력 활용을 위한 위탁업체의 기준 에 대한 제도적 장치 마련은 검토할 필요가 있다. 또한 자격제도의 개편을 통해 관광분 야의 고용 전문성을 강화한다면 관광분야 종사자로서의 자긍심과 함께 전문성 강화에도 도움이 될 것으로 기대된다.

〈표 5-4〉 관광 부문 주요 자격증 현황

\begin{tabular}{|c|c|c|}
\hline 자격증 & 내용(수행직무) & 법적 근거 \\
\hline $\begin{array}{l}\text { 관광통역 } \\
\text { 안내사 }\end{array}$ & $\begin{array}{l}\text { 국내를 여행하는 외국인에게 외국어를 사용하여 관광지 및 관광대상물 } \\
\text { 을 설명하거나 여행을 안내하는 등 여행의 편의를 제공 }\end{array}$ & \multirow{2}{*}{$\begin{array}{l}\text { 관광진흥법 제 } 38 \text { 조 } \\
\text { (관광종사원의 } \\
\quad \text { 자격 등) }\end{array}$} \\
\hline $\begin{array}{l}\text { 국내여행 } \\
\text { 안내사 }\end{array}$ & $\begin{array}{l}\text { 국내를 여행하는 관광객을 대상으로 여행 일정 계회, 여행비용 산출, } \\
\text { 숙박시설예약, 명승지나 고적지 안내 등 여행에 필요한 각종 서비스를 } \\
\text { 제공 }\end{array}$ & \\
\hline $\begin{array}{l}\text { 국외여행 } \\
\text { 인솔자 }\end{array}$ & $\begin{array}{l}\text { 여행업자가 내국인의 국외여행을 실시할 경우 여행자의 안전 및 편의 } \\
\text { 제공을 위하여 그 여행을 인솔하는 자 }\end{array}$ & $\begin{array}{l}\text { 관광진흥법 제13조 } \\
\text { (국외여행 인솔자) }\end{array}$ \\
\hline $\begin{array}{l}\text { 호텔 } \\
\text { 경영사 }\end{array}$ & $\begin{array}{l}\text { 관광사업소의 호텔에서 객실예약업무, 객실판매 및 정비업무, 접객업 } \\
\text { 무, 회계업무, 식당업무 등 제반 호텔관리업무에 대한 계획을 수립, 조 } \\
\text { 정하며 조사원 근무상태를 지휘 감독하는 직무 }\end{array}$ & \multirow{3}{*}{$\begin{array}{l}\text { 관광진흥법 제 } 38 \text { 조 } \\
\text { (관광종사원의 } \\
\text { 자격 등) }\end{array}$} \\
\hline $\begin{array}{l}\text { 호텔 } \\
\text { 관리사 }\end{array}$ & $\begin{array}{l}\text { 특2등급 이상의 관광호텔업의 객실관리 책임자 업무와 } 1 \text { 등급 이하의 } \\
\text { 관광호텔업과 한국전통호텔업, 수상관광호텔업, 휴양콘도미니엄업 및 } \\
\text { 가족호텔업의 총괄 관리 및 경영업무를 수행 }\end{array}$ & \\
\hline $\begin{array}{l}\text { 호텔 } \\
\text { 서비스사 }\end{array}$ & $\begin{array}{l}\text { 호텔에서 고객에게 각종 서비스를 제공하기 위하여 영접, 객실안내, 짐 } \\
\text { 운반, 객실예약, 우편물의 접수와 배달, 객실열쇠관리, 객실정리, 세탁 } \\
\text { 보급, 음식제공 등 각종 서비스를 제공하는 일 }\end{array}$ & \\
\hline
\end{tabular}

자료 : 한국산업인력공단 Q-Net, 한국여행업협회 홈페이지 


\section{4. 고용안전망 구축을 위한 정책 기반 마련}

\section{가. 관광산업 종사자 실태조사 추진}

본 연구에서는 여행업, 관광숙박업, 국제회의기획업 종사자를 대상으로 심층인터뷰를 통해 현재 나타나고 있는 고용에 대한 현황을 파악하는데 중점을 두었다면, 고용안전망 구축을 위한 사전단계로는 관광산업 고용안전망 구축에 대한 기초적인 실태조사와 기초 정보의 확보, 고용안전망 구축을 위한 필요성에 대해 관광업계의 설득을 위한 홍보와 공론화 과정이 필요할 것이다.

현재로는 고용안전망에 대한 기초적인 실태조사가 부족하여 본 연구에서 제시한 고용 안전망 사각지대의 규모 추정이 불가능한 실정이다. 현재 관광사업체조사에서는 종사자 들의 고용형태별 고용보험 가입률 등이 파악되지 않아 비정규직 부문의 사각지대 규모 나 고용 수준을 추정하는데 한계가 있다. 따라서 주기적으로 조사가 진행되는 관광사업 체조사나 문화체육관광 일자리 현황조사에 종사자의 규모뿐 아니라 근로형태와 고용실 태 등을 파악할 수 있는 조사항목이 추가되어야 한다. 이와 더불어 보다 구체적인 고용 안전망 구축을 위한 실태조사로서 관광진흥법상 7대 관광업종 및 유관업종까지 포함한 관광 분야의 '일하는 사람'을 대상으로 실시하는 관광종사자 실태조사가 필요하다.

〈표 5-5〉 관광산업 고용관련 통계 현황

\begin{tabular}{|c|c|}
\hline 구분 & 조사항목 \\
\hline $\begin{array}{l}\text { 관광사업체 조사 } \\
\text { (국가승인통계) }\end{array}$ & - 종사자수, 신규채용 종사자 수, 연간 이직자 수, 종사원 자격증 보유현황 \\
\hline $\begin{array}{c}\text { 문화체육관광 일자리 현황조사 } \\
\text { (국가승인통계) }\end{array}$ & - 종사자수, 신규채용 및 퇴사인력 수, 임금, 근로일수 및 근로시간 등 \\
\hline
\end{tabular}

예컨대, 문화예술 분야는 '예술인실태조사'를 통하여 국내 예술인의 예술활동 분야, 기간, 활동 횟수, 고용형태, 프리랜서 종사여부, 예술활동 투입시간, 계약 체결, 예술활 동 수입 등을 파악하고 있다. 콘텐츠 산업은 국가승인통계인 '콘텐츠산업조사'와 별개로 '콘텐츠산업 창의인력 실태조사'를 격년 단위로 실시하고 있다. 콘텐츠산업의 인력 현황 과 전망을 파악하기 위한 조사로 콘텐츠산업 노동환경 개선을 위한 정책지원을 강화하 
기 위한 기초자료로 활용되고 있다(한국콘텐츠진흥원, 2021).

〈표 5-6〉 문화체육관광부 인력 실태조사 현황

\begin{tabular}{|c|c|}
\hline 구분 & 조사항목 \\
\hline $\begin{array}{l}\text { 예술인실태조사 } \\
\text { (국가승인통계) }\end{array}$ & $\begin{array}{l}\text { - 목적 : 예술인의 복지 및 창작환경에 대해 파악하여, 예술인의 권익보호와 복지 정책의 } \\
\quad \text { 수립 및 시행에 필요한 기초자료로 활용하는데 목적이 있음 } \\
\text { - 조사주기 : 3년 } \\
\text { - 조사단위 및 규모 : 개인 } 5,002 \text { 명 } \\
\text { - 조사항목 : 예술활동 분야 및 내용, 고용형태 및 근로환경, 생활 및 복지, 일반적 특성 } \\
\text { - 예술활동의 고용형태, 프리랜서 종사여부, 겸업 예술인의 활동시간 } \\
\text { - 예술황동 관련 계약 체결, 부당계약 체결, 사회보험 가입률, 경력 단절 현황 } \\
\text { - 예술인의 가구 총 수입, 예술활동 개인 수입 }\end{array}$ \\
\hline $\begin{array}{c}\text { 콘텐츠산업 } \\
\text { 창의인력 실태조사 }\end{array}$ & $\begin{array}{l}\text { - 목적 : 콘텐츠산업 창의인력의 고용형태 및 근로환경 등에 대한 분석 자료를 제공 } \\
\text { - 조사주기 : } 2 \text { 년(2018년 } 1 \text { 차 조사 진행) } \\
\text { - 조사단위 및 규모 : 사업체 } 1,027 \text { 개사, 사업체 소속근로자 } 1,251 \text { 명, } \\
\text { 프리랜서 } 1,109 \text { 명 대상 진행 } \\
\text { - 조사항목 : 사업체, 소속 근로자, 프리랜서로 구분 } \\
\text { - (사업체조사) 인력 현황, 프리랜서 활동 현황, 근로 여건, 고용 전망 } \\
\text { - (근로자조사) 근로 환경 및 복지, 부당 행위, 교육 현황 및 경력 관리, 산업 전망, 고용 } \\
\quad \text { 전망, 인구통계학적 특성 } \\
\text { - (프리랜서조사) 고용 및 계약 형태, 근로 환경 및 복지, 교육 현황 및 경력 관리, 산업 } \\
\quad \text { 전망, 고용 전망, 인구통계학적 특성 }\end{array}$ \\
\hline
\end{tabular}

관광종사자에 대한 고용형태의 경우, 관광사업체에 포함되어 근로를 영위하는 경우도 있지만, 정작 고용안전망이 필요한 종사자의 경우 관광사업체에 포함되지 않은 특수고용 직종이 적지 않다. 이 경우, 사업체 대상의 실태조사로는 규모 파악에 한계를 지닌다. 따라서 관광종사자들을 위한 고용관계 $\mathrm{DB}$ 구축이 필요하다. 코로나19 상황에서 특수 고용직종에 대해서 긴급고용안정지원금을 신청하는 경우, 일부 고용안전망 사각지대의 종사자에 대한 실태 파악이 가능하였다. 고용노동부의 큐넷(Q-Net), 워크넷(Worknet), 고용행정통계(EIS) 등과 연계한 관광산업 인력 $\mathrm{DB}$ 구축을 통하여 체계적인 실태 파악이 요구된다.

\section{나. 법제도 개선}

관광산업정책에서 근로조건, 노동문제 등 노동권에 관한 논의는 그동안 핵심적인 정 책으로 다루어지지 않았다. 관광산업은 대표적인 노동집약 산업임에도 불구하고, 종사자 들의 근로환경 및 조건에 관한 정책적 논의는 크게 주목받지 못해왔다. 관광산업에서 
노동 관련 이슈는 대부분 고용의 관점, 즉 관광산업 활성화로 인한 고용창출 효과에 집 중되어 있었다. 이 때문에 고용창출 이외의 노동 문제들은 주변적 논의로 인식되었다(이 경희·김근주, 2019).

관광산업 종사자의 노동권 보호는 인적 서비스를 바탕으로 하는 관광산업의 경쟁력과 도 직결된다. 고품질의 관광서비스 제공은 관광산업 종사자가 충분히 존중받을 수 있는 노동조건에서 가능하기 때문이다. 관광산업 종사자의 노동권이 보장될 때 인적 서비스를 기반으로 하는 관광산업의 지속가능한 발전 또한 가능하다(이경희·김근주, 2019).

관광기본법18)에는 관광 종사자의 자질 향상, 관광진흥법에는 관광종사원에 관한 사 항을 명시하고 있다. 관광진흥법 제7절에서 관광종사원의 자격 등(제38조), 교육(제39 조), 자격취소 등(제 40 조) 관련된 규정을 두고 있다. 관광종사자에 대한 현행 법의 특징 은 종사자의 자격과 유형 등을 명시할 뿐, 종사자의 근로조건 등 보호에 관한 사항은 포함하고 있지 않다는 한계가 있다.

\section{「관광진흥법」}

제13조(국외여행 인솔자) (1)여행업자가 내국인의 국외여행을 실시할 경우 여행자의 안전 및 편의 제공을 위하 여 그 여행을 인솔하는 자를 둘 때에는 문화체육관광부령으로 정하는 자격요건에 맞는 자를 두어야 한다. (2) (5) (생략)

제38조(관광종사원의 자격 등) (1) 관할 등록기관등의 장은 대통령령으로 정하는 관광 업무에는 관광종사원의 자격을 가진 자가 종사하도록 해당 관광사업자에게 권고할 수 있다. 다만, 외국인 관광객을 대상으로 하는 여행업자는 관광통역안내의 자격을 가진 사람을 관광안내에 종사하게 하여야 한다.

(2) (9) (생략)

제39조(교육) 문화체육관광부장관 또는 시·도지사는 관광종사원과 그 밖에 관광 업무에 종사하는 자의 업무능 력 향상을 위한 교육에 필요한 지원을 할 수 있다.

앞서 살펴본 것처럼 현행 법 상 관광종사자를 보호하기 위한 법령의 부재는 시급한 당면과제이다. 현재와 같은 산업의 위기 상황에서 고용보험의 사각지대에 놓여있는 인력 에 대한 보호 장치 마련은 제도적 근거가 필요하기 때문이다.

최근에는 기존 노동관계법 적용을 대신하는 별도의 법을 통해 사각지대 종사자에 대 한 보호장치 마련 방안도 논의되고 있다. 개별법을 통해 직종별 노동조건을 규정하는 방식으로 가사노동자 보호를 위한 '가사근로자법, 택배 등 물류종사자를 위한 '생활물류

18) 제 11 조(관광 종사자의 자질 향상) 정부는 관광에 종사하는 자의 자질을 향상시키기 위하여 교육훈련과 그 밖에 필요한 시책을 강구하여야 한다. 
서비스업법'이 각각 추진되고 있다. 특히, 가사근로자법은 노동법 및 사회보험의 사각지 대에서 근로자로서 권리를 누리지 못하였던 가사근로자들이 노동권을 보장받을 수 있는 제도적 기반이 마련되었다는 점에서 시사하는 바가 크다. 동 법의 제정으로 가사근로자 는 근로기준법, 최저임금법 등의 보호를 받게 되고, 고용보험·산재보험 등 사회보험도 적용되어 실직이나 산업재해의 위험에 대비할 수 있게 되었다(고용노동부 보도자료, 2021.5.21.).

〈표 5-7〉 종사자 보호를 위한 법령 제정 현황

\begin{tabular}{|c|c|}
\hline 법령명 & 주요 내용 \\
\hline $\begin{array}{c}\text { 가사근로자의 } \\
\text { 고용개선 등에 관한 } \\
\text { 법률 } \\
\text { [시행 2022.6.16.] }\end{array}$ & $\begin{array}{l}\text { - (가사서비스 제공기관 인증제) 가사근로자를 유급으로 고용하고, 서비스 제공 중 인적. } \\
\text { 물적 손해에 대한 배상 수단 등을 갖춘 법인을 가사서비스 제공기관으로 인증 } \\
\text { - (가사근로자 근로조건) 가사서비스 제공기관과 근로계약을 체결한 가사근로자에게 노 } \\
\quad \text { 동관계법이 적용되어 최저임금, 사회보험, 퇴직금, 연차 유급휴가 등의 권리 보장 } \\
\text { - (가사서비스 이용계약) 제공기관과 이용자 간에 서비스 종류·제공시간·이용요금·손해배 } \\
\quad \text { 상 관련 사항 등이 포함된 이용계약을 서면으로 체결 }\end{array}$ \\
\hline $\begin{array}{c}\text { 생활물류서비스 } \\
\text { 산업발전법 } \\
\text { [시행 2021.7.27.] }\end{array}$ & $\begin{array}{l}\text { - (표준계약서) 분류업무 명확화, 심야배송 제한 등 종사자의 적정 작업조건을 보장하고, } \\
\text { 공정한 계약 체결을 유도하기 위한 표준계약서 작성·사용을 위한 근거가 마련 } \\
\text { - (계약갱신청구권) 택배 종사자의 안정적 계약을 보장하기 위해 특별한 사유가 없는 이 } \\
\text { 상 6년 간의 운송 위탁계약을 보장하는 계약갱신청구권이 도입 } \\
\text { - (사업자의 안전관리 의무) 택배사업자의 업무를 위탁받은 영업점이 종사자에 대한 안전 } \\
\text { 조치 및 보건조치 이행 여부를 관리하는 안전관리 의무가 택배사업자에게 부여 } \\
\text { - (소화물배송 공제조합) 배달대행·퀵서비스 등 소화물배송 종사자의 유상운송 보험료 부 } \\
\text { 담 저감을 위한 '소화물배송 공제조합' 설립근거 마련 } \\
\text { - (휴식공간) 생활물류 종사자를 위한 쉼ㅌㅓㅓ 조성 근거가 마련되는 한편, 사업자에게 종사 } \\
\text { 자 휴게시설 확보 의무 부여 }\end{array}$ \\
\hline
\end{tabular}

자료: 고용노동부 보도자료(2021.5.21.), 국토교통부 보도자료(2021.1.8.)

\section{다. 업계와 종사자의 인식 개선 및 정책 홍보}

고용안전망의 필요성을 관광종사자들이 인식하고, 관광사업자 역시 적극적으로 고용 안전망 구축에 대해 협조할 수 있도록 보다 폭넓은 정책적 공감대 형성과 홍보 노력이 요구된다. 2021년 6월 기준, 특수형태근로자의 고용보험 시행 과정에서 골프장경기보 조원 등은 고용안전망의 필요성에도 불구하고 고용보험 의무가입 대상에서 제외되었다. 이는 일부 골프장경기보조원의 고용보험 부담뿐 아니라, 사업장의 부담으로 인한 사업자 반대가 일부 있었기 때문으로 알려지고 있다. 장기적 관점에서 고용보험 가입은 고용안 전망에 편입된 근로자와 사업자 모두 갈등관계의 완화, 체계적인 고용관계 개선, 미래 
실업에 대한 부담 완화 등 사회적 측면뿐 아니라 사업자와 근로자 개인에게도 도움이 되므로 이에 대한 이해와 관심을 알릴 필요가 있다. 관광업계를 대상으로 고용안전망의 중요성과 유사시례, 그리고 코로나19 상황 등 관광위기상황이 발생할 경우 가져올 관광 업계와 근로자의 피해를 알려 고용안전망 구축에 대한 적극적인 대응이 중요함을 제시 할 필요가 있다.

콘텐츠산업 등 문화체육관광부 소관 다른 산업분야와 비교할 때, 콘텐츠분야는 종사 자들이 처한 불공정계약 상황 등 특수성이 널리 알려져 있어 표준계약서 제정 등 종사자 를 보호하기 위한 정책추진이 관광산업에 비해 활발한 편이다19). 그러나 관광산업 종사 자들의 경우 현재까지 큰 이슈는 비교적 적어 논의되지 않고 있으나, 잠재된 문제가 언 제든 표면화할 가능성이 있으므로 타 분야에 비해 구체적으로 어떤 상황에 놓여있는지 에 대한 모니터링은 지속적으로 요구된다.

인터뷰 과정에서 계약서를 쓰지 않고 근로 행위가 발생하는 경우나 여전히 구두로 계 약이 이루어지는 경우 등이 언급되었는데, 실제로 전체 산업 대비 관광 관련 산업 중 숙박 및 음식점업과 예술, 스포츠 및 여가관련 서비스업은 근로계약서 서면작성 비율이 낮게 나타난다. 고용안전망 강화를 위해서는 이러한 기존 업계의 잘못된 관례를 과감히 개선할 필요가 있다.

〈표 5-8〉 근로계약서 서면작성 비율

(단위: \%)

\begin{tabular}{c|c|c|c}
\hline \multirow{2}{*}{ 산업 } & \multicolumn{2}{|c|}{ 근로계약서 서면작성비율 } & \multirow{2}{*}{$\begin{array}{c}\text { 증감 } \\
\text { (B-A) }\end{array}$} \\
\cline { 2 - 3 } & 2019년 8월(A) & 2020년 8월(B) & (전체 \\
\hline I, 숙박 및 음식점업 & 41.4 & 74.0 & 2.7 \\
\hline N. 사업시설 관리, 사업 지원 및 임대 서비스업 & 84.6 & 50.7 & 3.2 \\
\hline R. 예술, 스포츠 및 여가관련 서비스업 & 68.4 & 85.1 & 0.7 \\
\hline
\end{tabular}

자료: 경제활동인구조사 부가조사

19) 문화체육관광부는 '콘텐츠산업 3대 혁신전략'을 발표(2019.09.17.)하였는데, 종사자 인권 보호와 노동환 경 개선을 위한 콘텐츠 표준계약서 제·개정, 주52시간 근로제 적용 확대, 콘텐츠 공정상생센터 역할.기능 강화, 콘텐츠·영화분야 성폭력 대응 등 전담개관 개소, 방송제작현장 안전가이드라인개발, 콘텐츠 일자리 체질 개선 컨설팅 강화 등을 포함하고 있다. 


\section{5. 정책과제 종합}

관광산업 고용안전망 강화를 위한 정책은 다음과 같이 각 업종별 특성에 맞게 제시할 수 있다. 심층인터뷰 과정에서 파악된 세부업종인 여행업, 관광숙박업, 국제회의기획업 의 특성에 따른 고용안전망 사각지대에서 이들을 위한 정책과제를 제시하고, 여행업, 관 광숙박업, 국제회의기획업을 포함하여 관광진흥법상 전체 관광사업과 관광사업으로 포 함되어 있지는 않으나 연관업종까지 고려하여 관광산업 고용안전망 강화를 위한 과제를 제시하였다.

관광산업 고용안전망 정책과제의 도식화는 크게 각 업종별 특성과 사각지대의 근로자 형태를 분석하고, 이에 대한 현재 현황과 문제점, 개선방안에 대한 형태로 제시하였다. 각 정책과제의 큰 틀은 다시 군집화하여 향후 추진해야 할 정책과제와 연동하여 제시하 였다. 다음의 그림은 이러한 고용안전망 정책과제를 업종별로 구성하고, 전반적인 관광 산업에 공통적으로 해당되는 부문을 제시한 것이다. 


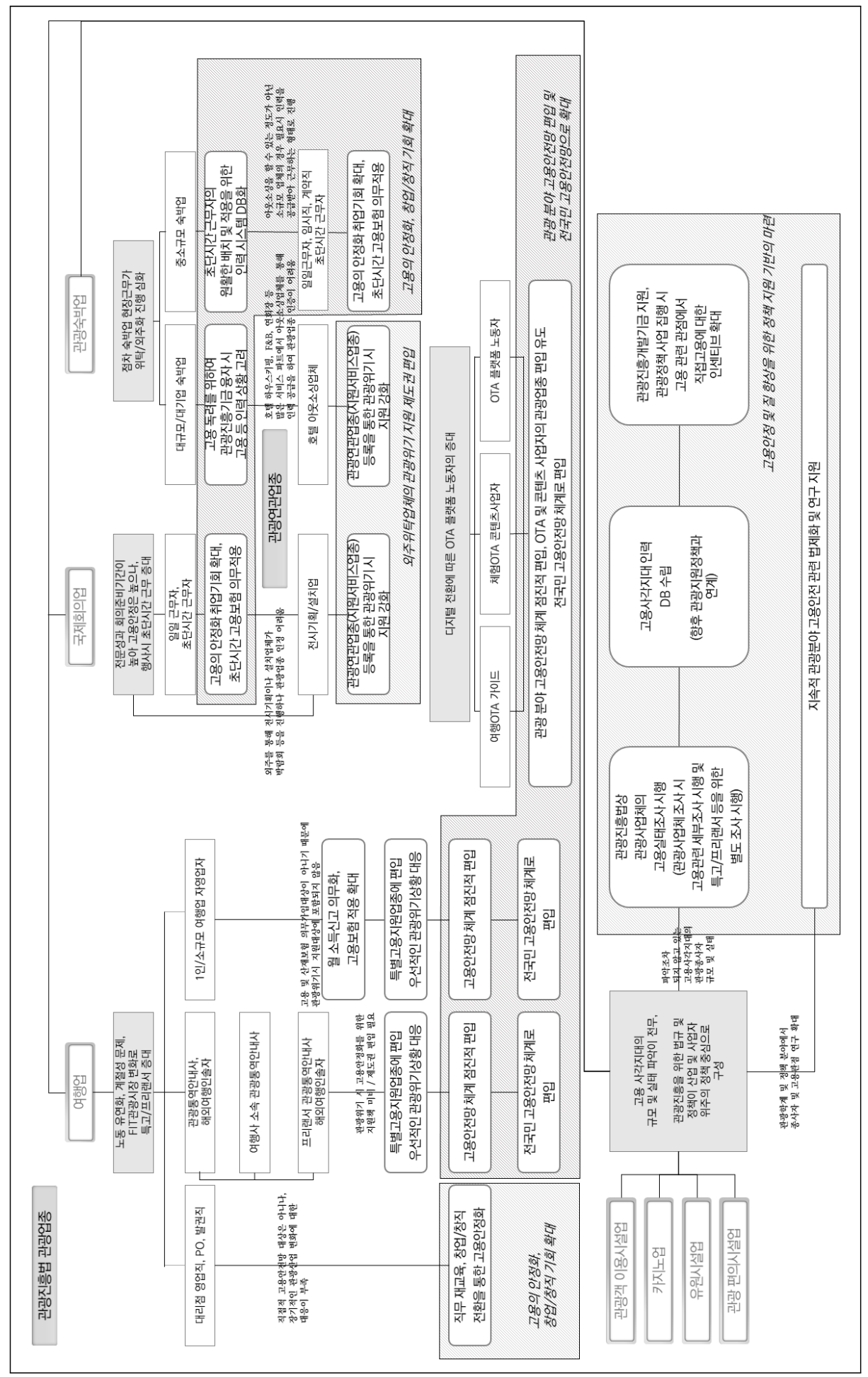


관광산업 고용안전망 구축방안

\section{제6장}

결론 및 제언 



\section{제1절 결론}

코로나19의 영향으로 관광산업은 전례 없는 위기를 겪고 있다. 특히 코로나19의 영향 이 장기화되면서 종사자들의 고용 위기로 이어질 우려가 커지고 있어 정책적 대응방안 마련이 요구된다. 그동안 관광산업 종사자의 고용안전망에 대한 실태 분석은 정책 연구 가 미흡한 영역이었다. 이 연구는 관광산업의 고용안전망 사각지대 규명을 위한 탐색적 연구로, 사각지대의 실태를 파악하고 고용안전망 구축을 위한 정책과제를 제안하였다.

고용안전망의 사각지대 진단에 앞서 관광산업의 노동시장 특성을 살펴보았다. 관광산 업은 타 산업에 비하여 노동의 유연성이 강한 산업으로 인식된다. 관광정책도 산업에 대한 지원 정책을 중심으로 설계되어 있어 상대적으로 일하는 사람에 대한 지원이 취약 한 것이 사실이다.

이 연구는 다양한 통계자료와 심층인터뷰 조사를 통하여 코로나19를 전후로 관광산 업에 종사하고 있는 노동자의 실태를 파악하였다. 특히, 고용안전망의 사각지대에 놓여 있는 종사자들, 예컨대 프리랜서로 활동해왔던 관광가이드를 비롯하여, 고용이 불안정한 임시직과 일용직 근로자, 초단시간 근로자, 위탁용역으로 인한 파견노동자와 사내하청 노동자 등은 코로나19의 위기 상황에서 고용의 취약성이 더욱 두드러졌다.

관광산업은 노동 유연성과 고용 변동성이 큰 산업으로 고용 불안정성이 크며, 근로조 건이 열악하고, 특히 고용 취약계층이 증가하고 있어 고용안전망을 통한 사각지대 보완 이 요구된다. 또한 관광산업은 상시적인 위기의 시대에서 가장 민감하게 반응하는 산업 이라는 점을 고려할 때, 고용안전망 강화의 필요성이 제기된다.

연구의 주요 결과를 바탕으로 관광산업의 고용안전망 강화를 위한 정책과제를 다음과 같이 제안하였다.

첫째, 관광산업에서 고용보험의 사각지대를 점검하고, 정부가 발표한 전 국민 고용보 험 로드맵에 따른 사각지대 해소와 가입대상 확대 방안을 제안하였다. 
둘째, 관광종사자의 전문성 강화 방안을 제안하였다. 종사자를 대상으로 한 재교육·재 취업, 직업교육 등 노동시장 변화에 대응하는 역량 강화 지원 방안을 제안하였다. 이는 현재 관광산업의 현안인 코로나 19 의 영향으로 휴직과 실업에 놓인 종사자들이 노동시장 에 재진입할 수 있도록 지원하기 위해 정책방안이 요구되기 때문이다.

마지막으로, 미래 노동시장 변화에 대비한 플랫폼 노동 실태파악과 관광산업 고용안 전망 구축을 위한 정책 기반으로 관광산업 종사자 실태조사 및 인력 $\mathrm{DB}$ 구축방안, 고용 안전망 구축을 위한 업계와 종사자의 인식 제고 등을 제안하였다.

관광산업은 코로나19로 위기를 맞고 있을 뿐 아니라, 코로나 이후 산업 전반의 구조 적 변화가 도래할 것으로 예상된다. 관광산업은 인적 서비스를 기반으로 하며, 인적 서 비스의 중요성은 산업 발전과 경쟁력의 핵심 요소로 중요하게 인식되고 있다. 관광산업 정책의 방향 설정에서도 그 중심에 '일하는 사람'에 있음은 자명하다. 국가적 차원에서 도 포스트코로나 시대를 준비하는데 관광의 역할이 중요하기 때문에 인적자원 활용 및 역량 강화와 고용안전망을 포함한 고용의 질적 여건 개선에 대한 종합적인 대책 마련이 요구된다. 


\section{제2절 정책 제언}

관광산업 고용안전망은 실직 등 사회적 고용 상 위험으로부터 관광종사자를 안전하게 보호하는 체계를 의미한다. 우리나라는 고용보험제도로 대표되는 고용안전망을 통하여 실업의 위기에서 근로자의 안정을 유지하고 다시 일할 수 있는 기회와 일자리 이동을 지원하고 있다. 고용안전망 구축과 전국민 고용보험제도는 고용노동부가 주도하는 정책 이나, 정부 차원의 정책 흐름에 따라 각 산업별, 업종별 접근을 통한 대응도 필요하다.

특히, 코로나19 상황에서 관광산업 생태계의 약한 연결고리라 할 수 있는 프리랜서 및 특수형태고용직종, 하도급 형태의 종사자, 관광진흥법 상의 관광사업에 해당이 되지 않는 종사자들은 제대로 된 지원을 받지 못하거나, 실업자로 내몰리는 현상이 나타나고 있다. 관광산업이 성장하기 위해서는 산업을 구성하는 기업의 역할도 중요하고, 종사자, 더 넓게는 일하는 사람 또한 중요하다. 관광산업의 고용안정성을 강화하기 위한 문화체 육관광부의 역할이 필요한 이유이다.

포스트코로나 시대에 대비하기 위해서는 국가적으로도 문화체육관광부의 역할이 커 질 가능성이 높다. 관광산업의 경쟁력 강화를 위하여 인적 경쟁력을 높이고, 고용의 질 을 강화하는 정책 추진이 요구된다. 문화체육관광부는 이를 위한 재원 마련을 고민하고, 영세한 사업체와 취약한 영역을 지원하기 위한 방안을 모색해야 한다. 관광업계 내부의 자정노력도 필요하다. 노동시장이 유연하게 운영되는 업계의 관행을 개선하고, 체계적인 관리와 제도권 편입 노력이 필요하다.

이 연구는 관광산업의 고용안전망 사각지대를 규명하고, 관광산업에서 고용안전망을 강화하기 위한 정책 방향과 과제를 제안하였다. 마지막으로 연구 결과를 종합한 시사점 은 다음과 같다. 


\section{가. 고용정책 흐름에 대응한 사각지대 해소 노력}

관광산업 고용안전망 사각지대 개선에 대한 정책방향은 관광산업 종사자들이 어떠한 업종이나 직종과 관계없이 직접적인 고용 형태와 고용보험 및 실업급여 적용 범위 내에 포함되어 전문성과 안전성 강화를 위한 기반을 마련하는 것을 목표로 추진해야 한다. 그동안 고용보험을 중심으로 설계된 고용안전망은 일하는 사람 전체를 포용하지 못하고, 고용보험을 기초로 한 노동시장정책이 제한적으로 작동된다는 점은 한계로 지적되어 왔 다. 특수형태근로종사자와 영세자영업자가 고용보험제도로 편입되는 노동시장정책이 논 의되고 있다는 점을 고려할 때, 관광산업의 고용보험 사각지대 발굴과 실태 규명을 통하 여 사각지대 해소 정책을 적극 추진할 필요가 있다.

전반적인 관광산업의 고용안전망 흐름에 대한 대응뿐 아니라 각 업종별, 고용형태별 다양한 고용 사각지대가 존재하는 만큼 이에 대한 대응도 요구된다. 고용형태의 다양화 는 업종별 특성이 비교적 명확히 나타나므로, 업종 특성별, 기업 규모별 대응전략을 달 리 설정하여 접근할 필요가 있다.

또한, 최근 고용정책이 디지털 시대의 고용안전망, 플랫폼 노동의 확산에 대한 대응방 안 모색 등 고용안전망의 범위가 확대되는 추세임을 고려할 필요가 있다. OTA 등 플랫 폼 기업의 증가에 따른 디지털 전환과 같은 관광환경 변화 속에서 관광산업 종사자들의 근무환경이나 직종 변경이 필요한 경우까지 고려하여 광범위한 수준에서의 고용의 안전 성을 지속할 수 있는 체계 마련도 요구된다.

\section{나. 관광산업의 미래 노동시장 변화에 대한 대비 필요}

미래 노동시장에서 고용형태 다변화에 큰 영향을 미칠 노동방식으로 디지털경제에 따 른 플랫폼노동이 대표적이다. 플랫폼 노동시장은 크게 웹 기반과 지역 기반으로 구분할 수 있는데, 우리나라의 플랫폼 노동시장의 특성에 적용한 것이 아래 그림으로, 플랫폼노 동이 얼마나 다양한 형태로 진행되고 있는지 잘 보여주고 있다(이승윤 외, 2020; 장지연 외, 2020).

플랫폼 종사자의 경우 플랫폼을 활용해서 노무를 제공한다는 것이 핵심이다. 정부가 발표한 로드맵 상 플랫폼은 보험 가입에서 신고나 관리나 증수 책임을 부담하고, 플랫폼 을 활용하는 사업주와 근로자, 노무제공자가 보험료를 부담하는 특수한 구조이다. 이 때 
문에 플랫폼의 사업주 책임도 포함하고 있다20).

[그림 6-1] 우리나라의 플랫폼 노동시장

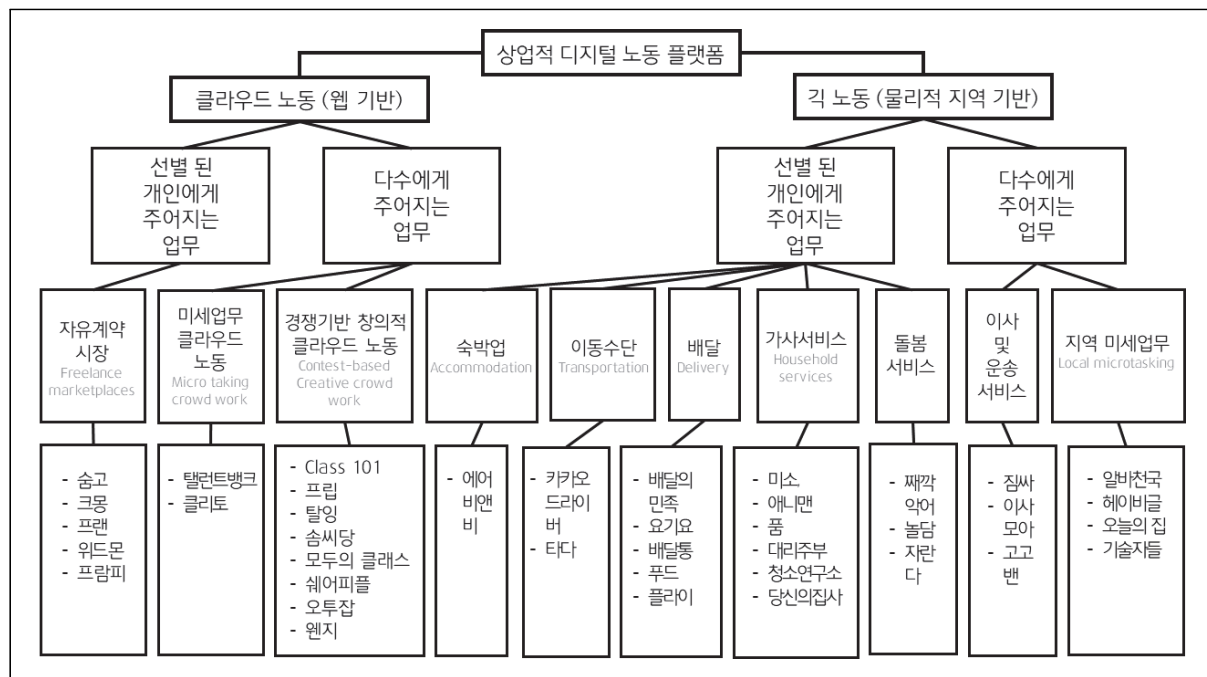

자료: 이승윤·백승호·남재욱(2020); 장지연 외(2020).

제시된 [그림 6-1]에서 관광산업 관련 플랫폼은 체험관광 상품과 액티비티를 중심으 로 한 프립과 숙박업의 에어비앤비 등이 해당되는데, 관광산업 역시 미래 노동시장에서 플랫폼 종사자가 증가할 것으로 예상된다. 특히 코로나19 팬데믹 이후 관광산업 생태계 에서 플랫폼의 역할이 커질 것이므로, 향후 노동시장에서 플랫폼의 역할과 플랫폼 종사 자의 노동권에 대한 논의를 확대할 필요가 있다.

예컨대 여행업의 경우, 앞서 제시하였던 프리랜서 등의 고용불안정성의 문제뿐 아니 라 관광분야의 예약 및 정보 접근이 OTA 플랫폼으로 전환되면서, 기존 인력에 대한 재 편 작업이 진행되고 있다. 또한 OTA 플랫폼은 종사자가 관광업종에 종사하는 것으로 분류되지 않는 경우도 존재하고, OTA 플랫폼을 통한 가이드 등록의 경우, 여전히 고용 불안정성이 발생할 우려가 있다. 이 때문에 관리 차원에서 정책적으로 OTA 플랫폼 운영 시 관광사업자 등록 유도와 OTA 내 콘텐츠 제공자 등에 대한 관리 방안을 마련할 필요 가 있다. 또한 OTA 플랫폼 종사자 실태 파악을 통해 노무제공자로 보호 필요성이 있는 사각지대를 규명하고, 관리 가능성과 보호 필요성에 대한 검토 과정을 통해 플랫폼 노동

20) 고용노동부가 발표한 ‘특수형태근로종사자 고용보험 세부 적용방안(2021. 2. 15.)'에 따르면 노무제공플 랫폼을 이용하는 경우 플랫폼사업주가 피보험자격 신고 및 보험료 원천공제·납부 의무 부담을 갖고 있다. 
자의 고용안전망 구축 방안을 모색할 필요가 있다.

\section{다. 관광산업의 지속가능한 발전과 경쟁력 강화를 위한 종사자 지원 확대}

관광산업은 인적 서비스를 기반으로 한다. 무엇보다 인적자원이 중요한 산업적 특성 을 갖는다. 관광객에게 고품질의 서비스를 제공하기 위해서는 인적 서비스가 수반되어야 한다. 서비스 품질의 강화는 관광산업 종사자의 서비스 전문성 강화, 나아가 관광산업 경쟁력 강화와도 연결된다. 관광산업 정책에서 양질의 일자리 조성과 인적 자원, 노동환 경의 개선이 강조되어야 하는 이유가 여기에 있다. 노동환경 개선은 관광산업의 서비스 품질 강화와 직결된다. 관광산업에서도 근로 조건 개선을 위한 정부와 사업자 공동의 노력이 필요하다.

관광산업 진흥 정책과 법제도적 틀에서도 인적 인프라에 직접 지원 할 수 있는 근거를 마련하는 게 중요하다. 고용유지지원금 제도와 같이 고용노동부의 정책과 차별화된 관광 종사자 대상 지원 제도 마련을 적극적으로 검토할 필요가 있다. 사업별 특수성에 따라서 교육 지원, 소득 보장 지원 등 제도적 틀을 갖출 필요가 있다. 관광산업은 제도적으로 고용안전망 관련 지원이 상당히 미흡한 실정이다. 특히, 고용 관점에서 일자리 전환이 일어나는 직종이 아니고 관광산업에 입직하게 되면 지속 종사하는 종사자들이 높은 업 종과 직종에 대한 지원을 강화할 필요가 있다.

마지막으로, 관광학계와 관광산업 정책 연구에서도 관광산업 종사자들을 위한 연구와 정책 과제 발굴을 강화할 필요가 있다. 이러한 접근이야말로 건전한 관광산업 육성을 위한 기본 전제조건이라 할 수 있기 때문이다. 코로나19로 인한 관광산업의 위기는 그동 안 미흡했던 노동권 보장에 대한 정책의 중요성을 환기하는 전환점이 되었다. 관광산업 이 그 어떤 산업보다 어려움을 겪고 있고, 코로나19의 종식과 산업의 회복 시점이 불투 명한 시점에서 이러한 위기감은 더욱 커지고 있다. 코로나19로 인한 산업의 위기는 노동 권 관점에서 정책을 점검하는 계기가 될 것으로 기대한다. 


\section{참고문헌}

- 강순희·황수경 외(2010), 고용구조 선진화를 위한 서비스산업의 일자리 창출 역량제 고 방안(II) -문화산업과 관광산업-. 한국노동연구원

- 경제사회노동위원회 관광산업위원회(2020.12.30.), 『코로나19와 호텔업 고용변화 실 태조사』

- 고용노동부(2018), 2018년 고용보험백서

- 고용노동부 보도자료(2020.3.16.), 「관광.공연업 등 특별고용지원 업종 지정 고시 제정

- 고용노동부 보도자료(2020.11.3.), 코로나19 긴급고용안정지원금 수급자 통계 분석 결과

- 고용노동부 보도자료(2020.12.16.), 제9차 고용정책심의회 결과

- 고용노동부 보도자료(2021.3.17.), 고용노동부, 특별고용지원 업종 추가지정 및 기존 업종 지원기간 연장 결정

- 고용노동부 보도자료(2021.9.16.), 항공업·여행업 등 특별고용지원 업종, 유급고용유 지지원금 지원기간 30 일 추가연장

- 고용노동부·한국고용정보원(2020.1월 2021.5월), 고용보험통계표

- 관계부처 합동(2019.2.19.), 문재인 정부「포용국가 사회정책 추진계획」

- 관계부처 합동(2020.7.14.), 한국판 뉴딜 종합계획: 선도국가로 도약하는 대한민국 대전환

- 권태일·송철재(2018), 문화체육관광 일자리 측정지표 개발에 관한 연구, 한국문화관 광연구원

- 김근주(2020), 고용안전망 체계 개편의 방향과 정책적 검토 사항, 노동정책연구, 제 20 권 제1호 pp.123 153. 한국노동연구원

- 김근주(2021), 적용범위 확대를 위한 고용보험법 개정의 의의와 과제, 노동리뷰, 한국 노동연구원

- 김덕기·김현주(2013), 관광산업의 고도화를 위한 생태계 구축방안, 한국문화관광연구 원 기본연구 보고서

- 김용기(2020), 사람중심 경제 전국민고용안전망 구축 방안 토론회(2020.7.8.) 자료집 축사 
- 김유빈·최충(2020), 고용·직업 안정성의 노동시장 효과 연구, 한국노동연구원

- 김현주(2012), 관광산업 인적자원 육성정책 체계화 방안 연구, 문화체육관광부·한국 문화관광연구원

- 김현주(2020), 코로나19가 가져온 관광산업 영향과 향후 전망, 문화관광인사이트 제 151 호

- 문화체육관광부(2020), 문화예술용역 운용지침서(가이드라인)

- 문화체육관광부(2021), 2020년 문화체육관광 일자리 현황 조사(상)

- 문화체육관광부 보도자료(2020.12.21.), 콘텐츠산업 일자리 창출과 안전망 강화에 힘쓴다

- 문화체육관광부·한국문화관광연구원(2020), 2019 관광사업체조사

- 문화체육관광부·한국문화관광연구원(2021), 관광R\&D 중장기 기술로드맵 수립 연구

- 박진희(2021), 행정DB를 이용한 고용보험 사각지대 발굴 및 분석, 한국고용정보원 세 미나 발표자료.

- 박혁·이종임·정은진(2021), 해외 주요국의 비정형 노동자 실업보험 현황, 노동리뷰 8 월호, pp.21-39.

- 백영식(2020), 전 국민 고용안전망 구축, 2021년 나라살림, KDI

- 윤소영·김혜인·이성우·안희자(2020), 문화안전망 구축을 위한 정책 방안 연구, 한국 문화관광연구원.

- 이경희·김근주(2019), 관광산업 종사자의 노동시간 실태와 삶의 질 연구, 한국노동연 구원

- 이문호 외(2020), 관광산업 현황과 노조의 대응전략, 전국서비스산업노동조합연맹 정 책보고서

- 이병희(2010), 고용안전망 평가와 개선방안. 노동리뷰, 37-51

- 이병희(2020), 전국민 고용보험과 한국형 실업부조, 사람중심 경제 전국민 고용안전망 구축 방안 토론회(2020.7.8.) 발표자료

- 이상동(2009), 고용안전망의 개념과 한국의 현황, 새로운사회를여는연구원.

- 이승윤 외(2020), 주요국 고용안전망의 현황과 시사점, 감사연구원 연구용역

- 이승윤·백승호·남재욱(2020), 한국 플랫폼노동시장의 노동과정과 사회보장제의 부정 합. 산업노동연구, 26(2), 77-135.

- 일자리위원회·관계부처 합동(2017.10.18.), 일자리정책 5년 로드맵

- 장지연·이병희·은수미·신동균(2011), 고용안전망 사각지대 해소방안, 한국노동연구원 - 장지연·이호근·조임영·박은정·김근주(2020), 디지털 시대의 고용안전망 - 플랫폼 노 동 확산에 대한 대응을 중심으로, 한국노동연구원 
- 정형선(1998), $\mathrm{OECD}$ 국가의 사회안전망, 보건복지포럼

- 정흥준(2020), 코로나19, 사회적 보호 사각지대의 규모와 대안적 정책방향, 고용노동 브리프 제97호. 한국노동연구원

- 한국문화관광연구원(2020), 2020년 문화체육관광 고용동향

- 한국콘텐츠진흥원(2021), 2020년 콘텐츠산업 창의인력 실태조사.

- 한희정(2020), 관광산업의 미래 일자리 전망과 대응방향, 한국문화관광연구원

- Hijzen, A. \& Martin, S.(2013), The role of short-time work schemes during the global financial crisis1 and early recovery: A cross-country analysis, IZA Journal of Labor Policy, 2(1), 출처: http://dx.doi.org/10.1186/2193-9004-2-5.

- Hijzen, A. \& Venn, D.(2011), The role of short-time work schemes during the 2008-09 Recession, OECD social, employment and migration working papers, No.115, OECD Publishing, Paris, 출처: https://dx.doi.org/10.1787/5 kgkd0bbwvxp-en.

- HotellerieSuisse (2020), Auswertung Umfrage Lageeinschatzung, HotellerieSuisse

- Ganong, P., P. Noel and J. Vavra(2020), US Unemployment Insurance Replacement Rates During the Pandemic, Working Paper, No.2020-62, Becker Friedman Institute for Economics at the University of Chicago, Chicago, 출처: https://github.com/ganong-noel/ui_calculator

- OECD(2014), The crisis and its aftermath: A stress test for societies and for social policies, in Society at a Glance 2014: OECD Social Indicators, OECD Publishing, Paris, 출처: https://dx.doi.org/10.1787/soc_glance-20145-en.

- OECD(2020a), COVID-19 Employment and social policy responses by country, 출처: http://oe.cd/covid19tablesocial

- OECD(2020b), Job creation and local economic development 2020: Rebuilding better, OECD Library, 출처: https://www.oecd-ilibrary.org/sites/432dbf4c-e n/index.html?itemId=/content/component/432dbf4c-en\#section-d1e15555

- OECD(2020c), OECD Employment outlook 2020: Work security and the CO VID-19 crisis, OECD Library, 출처: https://www.oecd-ilibrary.org/sites/168 6c758-en/1/3/1/index.html?itemId=/content/publication/1686c758-en\&_c $\mathrm{sp}_{-}=\mathrm{fc} 80786 \mathrm{ea} 6 \mathrm{a} 3 \mathrm{a} 7 \mathrm{~b} 4628 \mathrm{~d} 3 \mathrm{f} 05 \mathrm{~b} 1 \mathrm{e} 2 \mathrm{e} 5 \mathrm{~d} 7 \&$ itemIGO=oecd\&itemContentTyp e=book 
- Tourism Northern Ireland(2020.05), Job Retention Scheme for Tourism Businesses 웹세미나. 출처: https://www.youtube.com/watch?v=5tfuSFY9ffs

- UNWTO(2020.06), How are countries supporting tourism recovery?. UNWTO BRIEFING NOTE - TOURISM AND COVID-19, ISSUE 2.

- UNWTO(2020.08), The impact of COVID19 on Tourism. 출처: https://webu nwto.s3.eu-west-1.amazonaws.com/s3fs-public/2020-08/UN-Tourism-Poli cy-Brief-Visuals.pdf

- 건설근로자공제회 웹사이트(https://www.cw.or.kr/contents.do)

- 경제사회노동위원회 관광산업위원회 웹사이트(http://www.eslc.go.kr/)

- 두루누리 사회보험료 지원사업 웹사이트 (http://insurancesupport.or.kr/durunuri/intro.php)

- https://www.4insure.or.kr/html/totalinfo/tab01/page01.html 


\section{ABSTRACT}

\section{A Study on the Employment Safety Net for the Tourism Industry}

Heeja An, Hyejin Yoon, Ransoo Jeong

The COVID-19 pandemic has put the tourism industry in an unprecedented crisis. In particular, as the impacts of the pandemic have prolonged, there is a growing concern about the employment crisis of workers in the industry, which calls for policy measures to deal with this specific situation. There has been a lack of policy research in the analysis of an actual employment safety net for the workers in the tourism industry. Thus, this study set out, as a probe study, to identify blind spots in the employment safety net of the tourism industry, examining the actual conditions of blind spots, and proposing policy tasks to establish an employment safety net for the industry.

Before diagnosing a blind spot in the tourism industry, the study looked into the characteristics of the labor market in the industry. Generally, the tourism industry is considered to have higher labor flexibility than other industries. Tourism policies are designed around support for the industry, offering relatively weaker support for workers in the industry.

In the present study, the investigator collected diverse statistical materials and conducted an in-depth interview to examine the actual conditions of workers in the industry before and after COVID-19. Some groups of workers, who are in the blind spot of the employment safety net, have had their employment vulnerability revealed more prominently during the COVID-19 crisis, including freelance tourist guides, temporary and day workers whose employment is unstable, short-time workers, dispatched workers in consignment service, and in-house subcontract workers.

The tourism industry has a high level of employment instability driven by labor 
flexibility and employment variability, thus offering inferior working conditions to workers. As the number of workers with employment vulnerability increases, there is a need to supplement blind spots with an employment safety net. Considering that the tourism industry is the most responsive industry in the era of constant crises, it is needed to reinforce its employment safety net.

Based on the findings, the study proposes the following policy tasks to reinforce the employment safety net of the tourism industry: First, there is a need to check the blind spots of employment insurance in the tourism industry and follow the employment insurance road map for the entire nation published by the government to eliminate blind spots and expand the scope of subscribers.

Secondly, it is required to reinforce the professionalism of workers in the tourism industry. There should be supportive measures to reinforce their competence in reaction to the changes of the labor market, such as retraining, reemployment, and vocational education for workers in the industry. As many workers in the industry are on a leave of absence or unemployment due to the COVID-19 pandemic, they need policy measures to help them reenter the labor market.

Finally, it is critical to examine the actual conditions of platform labor for the future changes of the labor market, survey workers in the industry for their actual status and build a manpower database as a policy basis for the employment safety net of the tourism industry, and increase the perceptions of the industry and workers to establish an employment safety net.

Not only is the tourism industry faced with a crisis during the COVID-19 pandemic, but it also expects industry-wide structural changes. The tourism industry is based on human services, whose importance holds a crucial status in the development of the industry. Tourism also plays important roles in preparation for a post-COVID era at the national level, which calls for total solutions to improve the quality of employment, including the utilization of human resources and establishment of an employment safety net.

\section{Keywords}

employment safety net, employment crisis, COVID-19 pandemic 
집필내역

연구책임

안희자 한국문화관광연구원 부연구위원: 연구총괄(제1장 제6장)

공동연구

윤혜진 배화여자대학교 글로벌관광과 교수: 제3장 제2절, 제4장 제3절 일부

정란수 대안관광컨설팅 프로젝트수 대표: 제4장 제4절 일부, 제5장 제2절 일부

연구 참여

최서우 한국데이터연구소 대표: 제4장 제2절 일부

연구 자문

김근주 한국노동연구원 고용안전망연구센터장, 연구위원

정흥준 서울과학기술대학교 경영학과, 교수

\section{관광산업 고용안전망 구축방안}

발행인 김대관

발 행 처 한국문화관광연구원

서울시 강서구 금낭화로 154

전화 02-2669-9800 팩스 02-2669-9880

http://www.kcti.re.kr

인 쇄 일 2021년 10월 15일

발 행 일 2021년 10월 15일

인 쇄 인 (사)한국장애인이워크협회 일자리사업장

I S B N 978-89-6035-880-593300

DOI https://doi.org/10.16937/kcti.rep.2021.e18

이 연구보고서를 인용하실 때는 다음과 같은 사항을 기재해 주십시오.

안희자·윤혜진·정란수(2021), 관광산업 고용안전망 구축방안, 한국문화관광연구원 



\section{OPEN}

한국문화관광연구원

서울특별시 강서구 금낭화로 154

전화 02-2669-9800

팩스 02-2669-9880

www.kcti.re.kr 